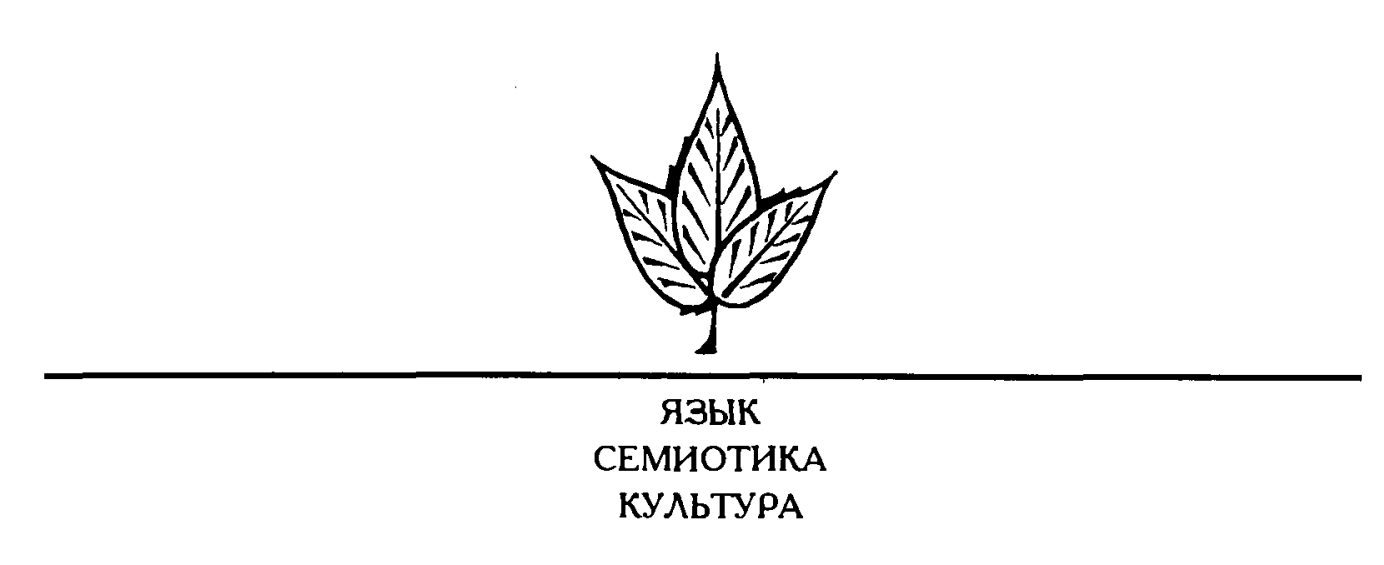

视 



\title{
Б.А. УСПЕНСКИЙ
}

\author{
Семиотика \\ искусства
}

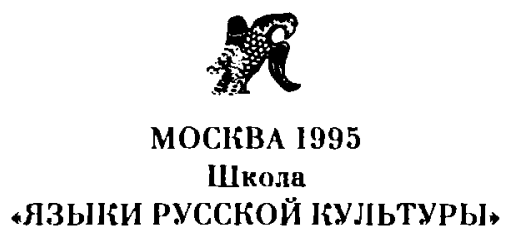




\title{
BEIf 81
}

y 58774

\author{
Б.А.Успенский \\ У 58 Семиотика искусства. - М.: Школа «Языки русской \\ культуры», июль 1995. - 360 с., 69 илл.
}

Издание осуществлено при финансовой поддержке Российского гуманитарного научного фонда согласно проекту 95-06-318266

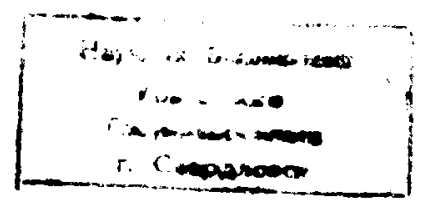

Except the Publishing House (fax: 095 246-20-20, E-mail: lrc@koshelev.msk.su) the Danish bookseller firm G·E·C GAD (fax: 458620 9102, E-mail: helle_d@danadata.dk) has an exclusive right on salling this book outside Russia.

Право на продажу этой книги за пределами России, кроме издательства, имеет только датская книготорговяя фирма G·E・C GAD.

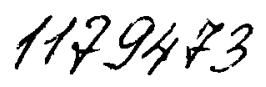

ISBN 5-88766-003-1 든.А.Успенский, 1995.

(C) А.Д.Кошелев. Серия «Язык. Семиотика. Культура*

(C) В.П.Коршунов. Оформление серии. 


\section{Оглавление}

\section{Поэтика композиции}

Введение. „Точка зрения“ как проблема композиции .......... 9

1. "Точки зрения“ в плане идеологии .......................... 19

2. „Точки зревия“ в плане фразеологии ........................ 30

3. "Точки зрения“ в плане пространственно-временно́й

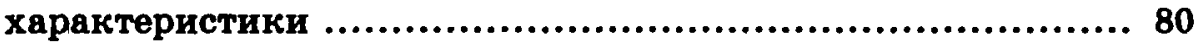

4. „Точки зрения“ в плане психологии ......................... 108

5. Взаимоотношение точек зрения на разных уровнях

в произведеник. Сложная точка зрения .....................133

6. Некоторые специальные проблемы композиции

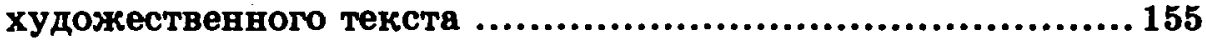

7. Структурная общность разных видов искусства.

Общие принципы организации произведения

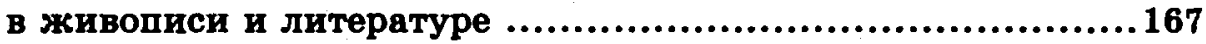

Краткий обзор содержания по главам .........................213

\section{Семпотнка иконы}

1. Общие предпосылки семиотического рассмотрения иконы

2. Принципы организации пространства

в древней живописи ..........................................246

3. Суммирование зрительного впечатления

как принцип организации древнего изображения ...........264

4. Семантический синтаксис иконы ........................... 274 


\section{Приложения: Статьн об искусстве}

„Правое“" и „левое“ в иконописном изображевии .................297 Композиция Гентского алтаря Ван Эйка

в семиотическом освещении (Божественная и человеческая перспектива) ..................... 304

Цитируемая литература ......................................329

Список сокращений ........................................... 347

Список нллюстраций ......................................... 348

Именной указатель ............................................351 


\section{ПОЭТИКА КОМПОЗИЦИИ}

\section{СТРУКТУРА ХУДОЖЕСТВЕННОГО ТЕКСТА И ТИПОЛОГИЯ КОМПОЗИЦИОННОЙ ФОРМЫ}


Текст печатается по изданию:

Б.A.Успенский.

Поэтика композициц

(структура художественного текста

и типолотия композициовной формы)

М: Искусство, 1970. -

с исправлевиями и дополвениями. 


\section{Введение}

\section{„Точка зрения“ как проблема композицив}

Исследование композиционных возможностей и закономерностей в построении произведения искусства относится к числу наиболее интересных проблем әстетического анализа; в то же время проблемы композиции еще очень мало разработаны. Структурный подход к произведениям искусства позволяет выявить много нового в этой области. В последнее время часто приходится слыпать о с т р у т у р е произведения искусства. При этом данное слово, как правило, употребляется не терминологически; обычно это не более чем заявка на некоторую возможную аналогию со еструктурой», как она понимается в объектах естественных наук, но в чем именно может состоять эта аналогия - остается неясным. Разумеется, может быть много подходов к вычленению структуры произведения искусства. В предлагаемой книге рассматривается один из возможных подходов, а именно подход, связанный с определением т о е к з рен и я, с которых ведется повествоввние в художественном произведении (или строится изображение в произведении изобразительного искусства), и исследующий взаимодействие этих точек зрения в рвзличных аспектах.

Итак, основное место в данной работе занимает проблема точки зрения. Она представляется ц е н т р а л в н й проблемой композиции произведения искусства - объединяюцей самые различные виды искусства. Без преувеличения можно сказать, что проблема точки зрения имеет отношение ко всем видам искусства, непосредственно связанным с семантикой (т.е. репрезентацией того или иного фрагмента действительности, выступающей в көчестве обозначаемого), - например, таким, как художественная литература, изобразительное искусство, театр, кино, - хотя, разумеется, в различных видах искусства эта проблема может получать свое специфическое воплощение.

Иначе говоря, проблема точки зрения имеет непосредственное отношение к тем видам искусства, произведения которых, по опре- 
делению, д в у п л а н о в ы, т.е. имеют выражение и содержание (изображение и изображаемое); можно говорить в этом случае о ре п р е з н т а т и ны х видах искусства 1 .

В то же время проблема точки зрения не так актуяльна - и может быть даже вовсе нивелирована - в тех областях искусства, которые не связаны непосредственно с семантикой изображаемого; ср. такие виды искусства, как абстрактная живопись, орнамент, неизобразительная музыка, архитектура, которые связаны преимущественно не с семантикой, а с с и н т к и к о й (а архнтектура еще и с пратматикой).

В ж и В о П и с и и В других видах изобразительного искусства проблема точки зрения выступает прежде всего как проблема п е р с п е к т и в ы 2 . Как известно, классическая «прямая, или нлинейная перспектива , которая считается нормативной для европейской живописи после Возрождения, предполагает единую и неподвижную точку зрения, т.е. строго фиксировавнуко зрительную позицию. Между тем — как это уже неоднократно отмечалось исследователями - прямая перспектива почти никогда не бывает представлена в абсолютном виде: отклонения от правил прямой перспективы обнаруживаются в самое развое время у самых крупных мастеров послевозрожденческой живописи, включая сюда и самих создателей теории перспективы ${ }^{3}$ (более того, эти отклонения в определенных случаях могут даже рекомендоваться живописцам в специяльных руководствах по перспективе - в целях достижения большей естественности изображения ${ }^{4}$ ). В этих случяях становится возможным говорить о м н ж е с т е н н о с и зрительных позиций, используемых живописцем, т.е. о множествен-

1 Заметим, что проблема точки зрения может быть поставлена в связь с известным явлением острянения ж е с т в н н о г о изображения (подробно см. ниже, с. 168-169).

О приеме остранения и его значении см.: Шкловский, 1919. IIкловский приводит примеры только для художественвой литературы, но сами утверждения его имеют более общий характер и в принципе, вндимо, должны быть отнесены ко всөм репревентативным видам искусства.

2 Менее всего әто относится к скульптуре. Не останавливаясь специально на әтом вопросе, заметим, что и в отношении пластичөских искусств проблема точки зрения не теряет своей актуальности.

3 И, напротив, строгое следованне канонам прямой перспективы харвктерно для ученических работ и часто для пронзведений небольшой художественной ценности.

4 См., например: Рынин, 1918, с. 58, 70, 75-79. 
ности точек зрения. Особенно наглядно әта множественность точек зрения проявляется в средневековом искусстве, и прежде всего в сложном комплексе явлений, связанных с так называемой „обратной перспективой 5 .

С проблемой точки зрения (зрительной позиции) в изобразительном искусстве непосредственно связаны проблемы ракурса, освещения, а также и такая проблема, как совмещение точки зрения внутреннего зрителя (помешенного внутрь изображаемого мира) и зрителя вне изображения (внешнего наблюдателя), проблема различной трактовки семантически важных и семантически не важных фигур и т.п. (к этим последним проблемам нам еще предстоит вернуться в данной работе).

В к и н о проблема точки зрения со всей отчетливостью выступает прежде всего как проблема м о т а ж а ${ }^{6}$. Множественность точек зрения, которые могут использоваться при построении кинокартины, совершенно очевидна. Такие элементы формальной композиции кинокадра, как выбор кинематографического плана и ракурса съемки, различные виды движения камеры и т.П., также очевидным образом связаны с данной проблемой.

Проблема точки зрения выступает также и в т е а т ре, хотя здесь она, может быть, и менее актуальна, чем в других репрезентативных видах искусства. Специфика театра в этом отношении наглядно проявляется; если сопоставить впечатление от пьесы (скажем, какой-либо пьесы Шекспира), взятой как литературное произведение (т.е. вне ее драматического воплощения), и, с другой стороны, впечатление от тои же самой пьесы в театральной постановке - иными словами, если сопоставить впечатления читателя и зрителя. «Когда Шекспир в „Гамлете“ показывает читателю театральное представление, - писал по әтому поводу П.А.Флоренский, - то он пространство этого театра дает нам с точки зрения зрителей того театра - Король, Королева, Гамлет и пр. И нам, слушателям [или читателям. - Б.У.], не составляет непосильного труда представить себе пространство освовного действия „Гамлета“ и в нем - выделенное и самозамкнутое, не подчиненное первому, пространство разыгранной там пиесы. Но в театральной постановке, хотя бы с этой только стороны, - „Гамлет“ представляет трудности непреодолимые: зритель театрального зала неизбежно видит

5 См.: Флоренскии, 1967; Жегин, 1970; Успенскии, 1970.

6 С.. о монтаже известные работы Энзентейна: Эйзенштейн, I-VI. 
сцену на сцене со своей точки зрения, а не с таковой же - действующих лиц трагедии, - видит ее своими глазами, а не глазами Короля, напрнмер ?.

Тем самым возможности перевоплощения, отождествления себя с героем, восприятия, хотя бы временного, с его точки зрения - в театре гораздо более ограниченны, нежели в художественной литературе ${ }^{8}$. Тем не менее можно думать, что проблема точки зрения в приндипе может быть актуальна - пусть не в той степени, как в других видах искусства, - и здесь.

Достаточно сравнить, например, современный театр, где актер свободно может повернуться спиной к зрителю, с классическим театром XVIII и XIX веков, когда актер обязан был быть обращенным к зрителю лицом - причем данное правило действовало настолько неукоснительно, что, скажем, два собеседника, разговаривагоцие ва сцене tête à tête, могли вовсе не видеть друг друга, но обязаны были смотреть на зрителя (в качестве рудимевта старой системы эта условность может встречаться еще и сегодня).

Эти ограничения в построении сденического пространства были настолько непременны и важны, что они могли ложиться в основу всего построения мизансцены в театре XVIII-XIX веков, обусловливая делыи ряд необходимых следствий. Так, активная игра требует движения правой руки, и поэтому актер более активной роли в театре XVIII века выпускался обычно с правой от эрителя стороны сцены, а актера относительно более пассивной роли ставили слева (например: приндесса стопт слева, а рабыня, ее соперница, представляющдая активный персонаж, вбегает на сдену с правой от зрителя стороны). Далее: в соответствиц с тако расстановко актөр пассивнод роли находился в более выгоднои позиции, поскольку его относительно неподвижное положение не вызывало необходимости поворачиваться в профиль или спиной к эритель, - и поэтому эту позицико занимали актеры, роль которых характеризовалась больпей функциональной значимостью. В результате расположение действующих лиц в опере XVIII века подчинялось достаточно определевным правилам, когда солисты выстрапваготся параллельно рампе, располагаясь по висходящей иерархии слева направо (по отнопенияо

7 См.: Флоренский, 1993, с. 64-65. Ср. в әтой связи замөчания М.М.Бахтина о необходимой чмонологической оправе в драме (Бахтин, 1963, с. 22, 47).

${ }^{8}$ На әтом основании П.А.Флоренекий приходит даже к тому крайнему выводу, что театр вообще есть искусство в принципе низшее в сравнении с другими видами искусства (см. там жө). 
к зрителю), т.е. герой пли первый любовник помещается, например, первым слева, а за ним идет следугший по важности персонаж и т.д. ${ }^{9}$

Заметим, вместе с тем, что подобная фронтальность по отношению к зрителю, характерная - в той или иной степени - для театра начдная с XVII-XVIII веков, нетдпнчна для старннного театра в связи с иным расположеннем зрителей относительно сцевы.

Ясно, что в современном театре в большей степени учитывается точка зрения участников действия, тогда как в классическом театре XVIII-XIX веков учитывается прежде всего точка зрения зрителя (ср. сказанное выше о возможности ^внутренней $\mathbf{4}$ нвнешней * точки зрения в картине); разумеется, возможно и совмещение әтих двух точек зрения.

Наконец, проблема точек зрения со всей актуальностью выступает в произведениях х у д ж е с те н н о й лите р а т у р ы, которая и составит основной объект нашего исследования. Так же, как и в кино, в художественной литературе находит широкое применение прием монтажа; так же, как и в живописи, здесь может проявляться множественность точек зрения и находит выражение как \&внутренняя (по отношению к произведению), так и •внешняя точка зрения; наконец, ряд аналогий сближает - В плане композиции - художественную литературу и театр; но, разумеется, здесь есть и своя специфика в решении данной проблемы. Подробнее обо всем этом будет сказано ниже.

Правомерно сделать вывод, что в принципе может мыслиться общая теория композиция, применимая к различным видам искусства и исследующая закономерности структурной организации х уд ж е ственного тек ст а. При әтом слова «художественный и « текст здесь понимаготся в самом широком смысле: их понимание, в частвости, не ограничено областью словесного искусства. Таким образом, слово ^художественный понимается в значении, соответствующем значению английского слова «artistic , а слово *текст - как любая семантически организованная последовательность знаков. 'Вообе выражение «художественный

${ }^{9}$ Ск.: Гвоздев, 1924, с. 119; Лерт, 1921.

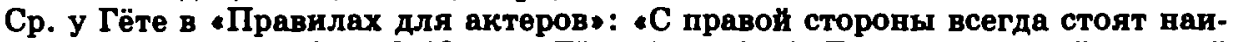
более почитаемые особы ( $\$ 42$, см.: Гёте, Х, с. 293). Говоря о правой и лөвой сторонах сцены, Гётө имеет в виду внутреннюю по отношению к сцене, а не внешнюю (зрительскуо) позиции - таким образом, правон считается та сторона, которая для зрителя являөтся левой (ср. в әтой связи с. 297-303, 308 и сл. наст. изд.). 
текст , как и «художественное произведение , может пониматься как в широком, так и в узком смысле слова (ограниченном областьо литературы). Мы будем стараться оговаривать то или другое употребление этих терминов там, где это неясно из контекста.

Далее, если м о т а ж - опять-таки в общем смысле этого слова (не ограниченном областью кино, но в принциде относимом к различвым видам искусства) - может мыслиться применительно к п о р о ж д е н и с т р-у к т у р о й художественного текста имеется в виду результат обратного процесса - его а в а л и з а 10 .

Предполагается, что структуру художественного текста можно описать, если вычленить различные точки зрения, т.е. авторские позиции, с которых ведется повествование (описание), и исследовать отношение между ними (определить их совместимость или несовместимость, возможные переходы от одной точки зрения к другой, что в свою очередь связано с рассмотрением Ф у н к ц и и использования той или иной точки зрения в тексте).

Исследованию проблемы точки зрения в художественной литературе посвящен ряд работ, среди которых для нас особое значение имеют труды М.М.Бахтина, В.Н.Волошинова (чьи идеи сложились под непосредственным влиянием Бахтина), В.В.Виноградова, Г.А.Гуковского; в американской науке эта проблема связана главным образом с течением «новой критики*, продолжағоей и развивахщей идеи Генри Джеймса. В работах әтих и других ученых показана прежде всего сама актуальность проблемы точки зрения для художественной литературы, а также намечены некоторые пути ее исследования. Вместе с тем, предметом әтих исследований было, как правило, рассмотрение творчества того или иного писателя, т.е. целого комплекса проблем, связанных с его творчеством. Анализ самой проблемы точки зрения не был, таким образом, их специальвой задачей, но, скорее, инструментом, с которым они подходили к изучвемому писателю. Именно поэтому понятие точки зрения обычно рассматривается нерасчлененно - подчас даже одновременно в нескольких развых смыслах - постольку, поскольку подобное рассмотрение может быть оправдано самим ис-

10 Лингвист обнаружит здесь прямую вналогио с моделями порождекия (синтеза) и моделями анализа в линтвстике. 
следуемым материалом (иначе говоря, поскольку соответствующее расчленение не было релевантно для предмета исследования).

В дальнейшем нам предстоит часто ссылаться на названных ученых. В своей работе мы попытались обобцить результаты их исследований, представив их как единое целое, и по возможности дополнить; мы стремились, далее, показать значение проблемы точек зрения для спедиальных задач композиции художественного произведения (стараясь при этом отмечать, где ато возможно, связь художественной литературы с другими видами искусства).

Таким обрвзом, центральную задачу настоящей работы мы видим в том, чтобы рассмотреть ти по логи и ком п о и и -

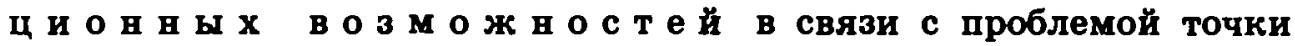
зрения. Нас интересует, стало быть, какие типы точек зрения вообще возможны в произведении, каковы их возможные отношения между собой, их функции в произведении и т.п. При этом имеется в виду рассмотрение данных проблем в общем плане, т.е. независимо от какого-либо конкретного писателя. Творчество того или иного писателя может представить для нас интерес только как иллюстративный материал, но не составляет специального предмета нашего исследования.

Естественно, результаты подобного анализа в первую очередь зависят от того, как понимвется и определяется точка зрения. Действительно, возможны различные подходы к пониманию точки зрения: последняя может рассматриваться, В частности, в идейноценностном плане, в плане пространственно-временно́й позиции лица, производящего описвние событий (т.е. фиксации его позиции в пространственных и временни́х координатах), в чисто лингвистическом смысле (ср., например, такое явление, как «несобственно-прямая речь») и т.д. Мы остановимся на всех этих подходах непосредственно ниже: именно, мы попытаемся выделить основные области, в которых вообще может проявляться та или иная точка зрения, т.е. планы рассмотрения, в которых она может быть фиксировапа. Эти планы будут условно обозначены нами как « план идеологии , «лан фразеологии», «план пространственновременно́й характеристики и «план психологии (рассмотрению каждого из них будет посвящена специальная глава, см. главы первую - четвертую) ${ }^{11}$.

11 Намек на возможность разщичепия точки зрепия спскхологической", "идеологической «, «еографнческой встречается у Г.А.Гуковского, см.: Гуковский, 1959 , с. 200. 
При этом следует иметь в виду, что данное расчленение на планы характеризуется, по необходимости, известной произвольностью: упомянутые планы рассмотрения, соответствующие возможным вообше подходам к выявлению точек зрения, представляются нам основными при исследовании нашей проблемы, но они никак не исключают возможности обнаружения какого-либо нового плана, который не покрывается данными: точно так же в принципе возможна и несколько иная детализация самих этих планов, нежели та, которая будет предложена ниже. Иначе говоря, данный перечень планов не является ни исчерпывающим, ни претендующим на абсолютный характер. Думается, что та или иная степень произвольности здесь неизбежна.

Можно считать, что различные подходы к вычленению точек зрения в художественном произведении (т.е. различные планы рассмотрения точек зрения) соответствуют различным у р о в я м анализа структуры этого проһзведения. Иначе говоря, в соответствии с различными подходами к выявленйю и фиксации точек зрения в художественном произведении возможны и разные методы описания его структуры; таким образом, на разных уровнях описания могут быть вычленены структуры одного и того же произведения, которые, вообще говоря, необязательно должны совпасть друг с другом (ниже мы проиллюстрируем некоторые случаи подобного несовпадения, см. главу пятую).

Итак, в дальнейшем мы сосредоточим свой анализ на произведениях художественной литературы (включая сюда и такие пограничные явления, как газетный очерк, анекдот и т.д.), но будем при этом постоянно проводить параллели:

a) с одной стороны, с другими видами искусства; эти параллели будут проводиться по ходу изложения, в то же время некоторые обобщения (попытка установления общих композиционных закономерностей) будут произведены в заключительной главе (см. главу седьмую);

б) с другой стороны, с практикой повседневной речи: мы будем всячески подчеркивать аналогии между произведениями художественной литературы и повседневной практикой бытового рассказа, диалогической речи и т.п.

Надо сказать, что если аналогии первого рода говорят об у н и в е с а л в о ст и соответствующих закономерностей, то аналогии второго рода свидетельствуют об их е с т с т в е - 
н о с т и (что может пролить свет, в свою очередь, на проблемы эволюции тех или иных композициоввых принципов).

При этом каждый раз, говоря о том или ином противопоставлении точек зрения, мы будем стремиться, насколько это возможво, приводить пример концентрации противопоставленных точек зревия в одной фразе, демонстрируя таким образом возможвость специальной композиционвой организации фразы как минимального объекта рассмотрения.

В соответствии с изложенными выше задачами мы будем иллюстрировать наши тезисы ссылками на самых разных писателей; более всего мы будем ссылаться на произведения Толстого и Достоевского. В то же время мы намеренно стараемся приводить примеры на различные композиционные приемы из одного и того же произведения, - с тем чтобы продемовстрировать возможность сосуществования самых разных принципов композиции. Таким произведением служит у нас •Война и мир» Толстого.

\title{
Условние обозначения, прднятые \\ при цитировании
}

Без специального указания мы ссылаемся на следующие издания:

\author{
«Гоголь - Н.В.Гоголь. \\ Полное собрание сочиневий \\ [в 14 т.] \\ М.: Изд-во АH CCCP, \\ $1937-1952$. \\ •Достоевский - Ф.М.Достоевский. \\ Полное собрание сочинений \\ B 30 T. \\ Л.: Наука, 1972-1990. \\ «есков" - Н.С.Лесков. \\ Собравие сочинений в 11 т. \\ М.: Гослитиздат, \\ $1956-1958$.
}




\section{Пушкин - [А.C.]Пушкин. \\ Полное собрание сочинений \\ [B 16 T.] \\ [M. ᄀI.]: Изд-во АH CCCP, $1937-1949$. \\ १олстой - Л.Н.Толстой. \\ Полное собрание сочинений \\ B 90 T. \\ М.-Л.: Гослитиздат, \\ $1928-1958$.}

При әтом ссылки на текст •Войны и мира даются по изданию 1937-1940 годов (дополнительный тираж), которое не стереотипво изданию в первом тираже (1930-1933 годы).

При цитировании әтих изданий мы упомиваем фамилию автора (или название сочинения, если автор недавно упомивался) с указавием прямо в тексте ва том и страницу.

При цитировании разрядкой всоду обозвачаются выделения в тексте, принадлежащие автору настоящей квиги, тогда как курсив используется для выделений в тексте, принадлежащих цитируемому автору. Многоточия в цитатах во всех случаях, когда нет специальной оговорки, привадлежат автору данвой работы. 


\section{1 „Точки зрения“ в плане идеологии}

Мы рассмотрим прежде всего самый общий уровень, на котором может проявляться различие авторских позиций (точек зрения) - уровень, который условно можно обозначить как и д е о л О Г и ч е с к и й или о д е н о ны й, понимая под соценкой : общую систему идейного мировосприятия. Отметим, что идеологический уровень наименее доступен формализованному исследованию: при анализе его по необходимости приходится в той или иной степени использовать'интуицию.

Нас интересует в данном случае то, с какой точки зрения (в смысле композиционном) автор в произведении оценивает и идеологически воспринимает изображаемый им мир. В принципе әто может быть точка зрения самого автора, явно или неявно представленная в произведении, точка зрения рассказика, не совпадающего с автором, точка зрения какого-либо из действующих лиц и т.п. Речь идет, таким образом, о том, что можно было бы назвать глубинной композиционной структурой произведения (которая может быть противопоставлена внешним композиционным приемам).

В тривиальном (с точки зрения композиционных возможностей) - и тем самым наименее интересном для нас случае - идеологическая оценка в произведении дается с о д в о й какой-то (доминирующей) точки зрения ${ }^{1}$. Эта единственная точка зрения подчиня'т себе все другие в произведении - в том смысле, что если в этом произведении присутствует какая-то другая точка зрения, не совпадающая с данной, например, оценка тех или иных явлений с точки зрения какого-то персонажа, то самый факт такой оценки в свою очередь подвергается оценке с этой основной точки зрения. Иначе говоря, оценивающий с у 6 ъ е к т (персонаж) становится в этом случае о 6 ъ е к т м оценки с более общей точки зрения.

В других случаях в плаве идеологии может прослеживаться определенная смена авторских позиций; соответственно можно говорить тогда $о$ р а $з$ и ч н ы х идеологических (или ценностных) точках зрения. Так, например, герой $A$ в пропзведении мо-

${ }^{1}$ Случай монологического построения по Бахтину (Бахтин, 1963). 
жет оцениваться с позиций героя $B$ или наоборот, причем различные оценки могут органически склеиваться воедино в авторском тексте (вступая друг с другом в те или иные отношения). Именно эти случаи, как более сложные в аспекте композиции, и будут представлять для вас преимущественный интерес.

Обратимся для примера к рассмотрению лермонтовского $Г$ Героя нашего времени». Нетрудно увидеть, что события и люди, составляющие предмет повествовавия, даны здесь в освещении различных мировосприятий. Иными словами, здесь присутствует несколько идеологических точек зрения, которые образуют достаточно сложную сеть отношевий.

В самом деле: личность Печорина дана нам глазами автора, самого Печорина, Максима Максимовича; далее, Грушницкий дается в свою очередь глазами Печорина и т.д. При этом Максим Максимович является носителем народной (наивной) точки зрения; его система оценок, например, будучи противопоставлена системе оценок Печорина, не противопоставлена, по сушеству, точке зрения горцев ${ }^{2}$. Система оценок Печорина имеет много общего с системой оценок доктора Вернера, в абсолютном большинстве ситуаций просто-напросто с вей совпадая; с точки зрения Максима Максимовича, Печорин и Грушницкий, возможно, могут быть отчасти похожи, для Печорина же Грушницкий - его антипод; княжна Мери вначале принимает Грушницкого за то, чем в действительности является Печорин; и т.д. и т.п. Различные точки зрения (системы оцевок), представленные в произведении, вступают, следовательно, в определенные отношения друг с другом, образуя таким образом достаточно сложную систему противопоставлений (различий и тождеств): некоторые точки зрения совпадают друг с другом, причем их отождествление может производиться в свого очередь с какой-то иной точки зрения; другие могут совпадать в определенной ситуации, различаясь в другой ситуации; наконец, те или иные точки зрения могут противопоставляться как противоположвые (опяь-таки с некоторой третьей точки зрения) и т.д. и т.п. Подобная система отношений при известном подходе и может трактоваться как композиционвая структура данного произведения (описываемая на соответствуюшем уровве).

При этом «Грой вашего времени представляет собой относительно п р о с т й случай, когда произведевие разбито на специ-

2 См.: Лотман, 1965, с. $31 \longrightarrow 32$. 
альные части, каждая из которых дана с какой-то особой точки зрения; иначе говоря, в различных частях произведения повествование ведется от лица развых героев, причем то, что составляет предмет каждого отдельного повествования, отчасти пересекается и объединяется общей темой (ср. еще более очевидный пример произведения подобной структуры - Лунный камень У.Коллинза). Но нетрудно представить себе и более сложный случай, когда аналогичное же сплетение различных точек зрения имеет место в произведении, не распадающемся на отдельные куски, но представляющем собой единое повествование.

Если различные точки зрения при этом не подчинены одна другой, но даются как в принципе равноправные, то перед нами произведение поли фонич еское. Понятие полифонии, как известно, введено в литературоведение М.М.Бахтиным ${ }^{3}$; как показал Бахтин, наиболее отчетливо полифонический тип художественного мыпления воплоцается в произведениях Достоевского.

В интересующем нас аспекте - аспекте точек зрения - явление полифонии может быть, как кажется, сведено к следующим основным моментам.

А. Наличие в произведении в е с о льк и х везависимых точек зрения. Это условие не требует специальных комментариев: сам термин (полифония, т.е. буквально ємногоголосиеь) говорит сам за себя.

Б. При этом данные точки зрения должны принадлежать непосредственно участникам повествуемого события (действия). Иначе говоря, здесь нет абстрактной идеологической позиции - вне личности какого-то героя ${ }^{4}$.

В. При этом данные точки зревия проявляются прежде всего в плане и д е о оги и, т.е. как точки зрения идеологически ценностные. Иными словами, различие точек зрения проявляется в первую очередь в том, как тот или иной герой (носитель точки зрения) оценивает окружающую его действительность.

-Достоевскому важно не то, чем его герой является в мире, пишет в әтой связи Бахтин, - а прежде всего то, чем является для героя мир и чем является он сам.для себя самого.. И далее: „Следовательно, теми элементами, из которых слагается образ героя, служат не черты действительности - самого героя и его бытового

8 См.: Вахтин, 1963.

Подробнее см.: Бахтин, 1963, с. 105, 128, 130-131. 
окружения, - но значение этих черт для него самого, для его самосознания 5 .

Таким образом, полифония представляет собой случай проявления точек зрения в плане идеологии.

Отметим, что столкновение разных идеологических точек зрения нередко используется в таком специфическом жанре художественного творчества, как анекдот; анализ анекдота в әтом плане, вообще говоря, может быть весьма плодотворен, поскольку анекдот может рассматриваться как относительно простой объект исследования с элементами сложной композиционной структуры (и, следовательно, в известном смысле как модель художественного пронзведения, у, тобная̆ для анализа).

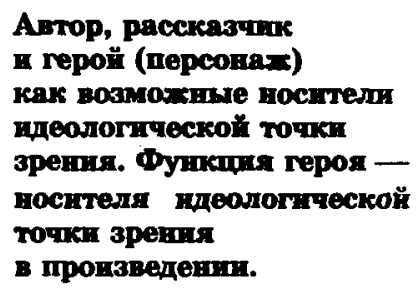

При анализе проблемы точек зрения в рассматриваемом аспекте существенно то, производится ли идеологическая оценка с некоторых абстрактных позиций (принципиально внешних по отношению к данному произведению ${ }^{6}$ ) или же с позиций какого-то персонажа, непосредственно представленного в анализируемом произведении. Заметим при этом, что и в первом и во втором случае возможны как одна, так и несколько позиций в произведении; вместе с тем, может иметь место и чередование точки зрения определенного персонажа и абстрактной авторской точки зрения.

Здесь следует сделать одну важную оговорку. Говоря об авторской точке зрения как здесь, так и в дальнейшем изложении, мы имеем в виду не систему авторского мировосприятия вообще (вне

${ }^{5}$ См.: Бахтин, 1963 , с. 63 , сp. еще с. $110-113,55,30$.

Заметим в то же время, тто момент самосознания, устремленность внутрь себя, столь характерная для героев Достоевского (ср.: Бахтин, 1963, с. 64-67, 103), кажется нам не столько признаком полифонии вообще, сколько специфическим признаком именно творчества Достоевского.

6 Такая оценка, как уже говорилось, в принципе невозможна в полифоническом произведении. 
зависимости от давного произведения), но ту точку эрения, которую он принимает при организации повествования в некотором конкретном произведении. При этом автор может говорить заведомо не от своего лица (ср. проблему “сказа») ${ }^{7}$, он может менять свои точки зрения, его точка зрения может быть двойной, т.е. он может смотреть (или: смотреть и оденивать) сразу с нескольких разных позиций и т.д. Все әти возможности будут подробнее рассмотрены ниже.

В том случае, когда оценка в произведении дается с точки зрения какого-то конкретного лица, представленного в самом этом произведении (т.е. персонажа), это лицо может выступать в произведении как гл а в н ы й ге p о й (центральная фигура) или же как в т о росте пе нн а я, даже әпизодическая фигура.

Первый случай достаточно очевиден: вообще должно сказать, что главный герой может выступать в произведении либо как п ре д м т оценки (например, Онегин в Евгении Онегине Пушкина, Базаров в ४Отцах и детях Тургенева), либо как ее носите л ь (таковы в большой степени Алеша в Братьях Карамазовых Достоевского, Чацкий в «Гре от ума Грибоедова).

Но очень распространен и второй способ построения произведения, когда в качестве носителя авторской точки зрения выступает какая-то второстепенная - чуть ли не әпизодическая - фигура, лишь косвенно относящаяся к действию. Такой прием, например, нередко применяется в киноискусстве: лицо, с точки зрения которого производится остравение, т.е., собственно говоря, тот зритель, для которого разыгрывается действие, - дается в самой картине, причем в виде достаточно случайной фигуры, на периферии картины. В этой связи можно вспомнить также - переходя уже в область изобразительного искусства - и о старых живописцах, помещавших иногда свой портрет у рамы, т.е. на периферии изображения ${ }^{8}$.

${ }^{7}$ Ср. в әтой связи слова Достоевского в письме к брату относительно критики «Бедных людей॰: «Во всем они [критики. - Б.У.] привыкли видеть рожу сочинителя; я же моей не показывал. А им и невдогад, что говорит Девушкин, а не я, и что Девушкив иначе и говорить не может" (Достоевский, т. XXVIII, кн. 1, с. 117). Речь идет здесь именно об идеологической позиции, т.е. 06 отношении к окружающему (изображаемому) миру.

O ссказе см. специально ниже (с. 32).

${ }^{8}$ Ср., например, Праздник четок Дюрера (щлл. 1), где художник изобразил самого себя в толпе людей у правого края картины, или «Поклонение волхвов Боттичелли (илл. 2), где имеет место в точности то же самое. Таким 
Во всех этих случаях лицо, с точки зревия которого производится остранение действия, т.е., по существу, зритель картины, дается в ней самой - в виде случайной фигуры на периферии действия.

В отношении же художественной литературы здесь достаточно сослаться на произведения классицизма. В самом деле, резонеры (как и хор в античной драме) обыкновенно мало участвуют в действии, они совмещают в себе участника действия и зрителя, воспринимающего и оценивающего данное действие ${ }^{9}$.

Мы говорили о том общем случае, когда носителем идеологической точки зрения выступает какой-то персонаж данного произведения (будь то главный герой или эпизодическая фигура). Но следует заметить, что речь идет, собственно говоря, не о том, что все действие реально дается через восприятие или оценку данвого лица. Лицо это может фактически и не принимать участия в действии (так, в частности, оно и происходит в том случае, когда данный персонаж выступает в качестве эпизодической фигуры) и, следовательно, липено необходимости ре а $\pi$ в н оценивать описываемые события: то, что видим мы (читатели), отличается от того, что видит - в изображаемом мире - данный персонаж ${ }^{10}$. Когда говорится при этом, что произведение построено с точки зрения определенно̆о персонажа, то имеется в виду, что если данный персонаж участвовал бы в действии, то он бы осветил (оценил) его именно так, как это делает автор произведения.

образом, художник здесь в роли зрителя, наблюдагщего изображенный им мир; но зритель әтот - сам внутри картины.

При әтом здесь обязательна о д н а идеологическая точка зрения. Помимо единства места, времени и действия, характерных, как известно, для классицистической драмы, для классицизма, несомвенно, характерно и единство идеологической позиции. Ср. очень четкое определение әтой стороны классицистического искусства у Ю.М.Лотмана: Для русско поәзии допушкинского периода характерно было схождение всех выряженных в тексте субъектнообъектных отношений в одном фиксированном фокусе. В искусстве XVIII века, традиционно определяемом как классицизм, әтот единый фокус выводился за пределы личности автора и совмещался с понятием истины, от лица которон и говорил художественный текст. Художественной точкой зрения становилось отношение истины к изображаемому миру. Фиксированность и однозначность әтих отношений, их радиальное схождение к единоку центру соответствовали представлению о вечности, единстве и неподвижности истины. Будучи единой и неизменяемой, истина была одновременно иерархичной, в разной мере открывагощейся разному сознапию (Лотман, 1966, с. 7-8).

10 Ниже мы сможем интерпретировать такое построение как случай несовпадения идеологической и пространственно-временно́й точки зрения. 
Можно вообще различать акту ульного йоте н ц и а л в о го носителя идеологической точки зрения. Подобно тому как точка зрения автора или рассказчика может бјть дана в одних случаях непосредственно в произведении (когда автор или рассказчик ведет повествование от своего лица), а в других случаях она может вычленяться в результтате специвльного анализа ${ }^{11}$, так и герой, являющийся носителем идеологической точки зрения, в одних случаях реально воспринимает и оценивает описываемсе действие, тогда как в друтих случаях его участие потенциально: действие описывается как бы с точки зрения данного героя, т.е. оценивается так, как оценивал бы его дандый герой.

В этом плане интересен такой писатель, как Г.К.Честертон. Если говорить о точке зрения на абстрактном мировоззренческом уровне, то почти всегда у Честертона тот, с чьей точки зрения оцениввется мир, - предстает как персонаж данной книги. Иными словами, едва ли не в каждой книге Честертона имеется лицо, которое могло бы написать данную книгу (мировоззрение которого отражается в книге). Можно сказать, что мир у Честертона изображается потевциально представленным и 3 н у т р и.

Мы затронули здесь проблему различения в в у т р е н н ей и в н е ш н е й точки зрения; это различение, отмеченное только что на идеологическом уровне, мы будем в дальнейшем прослеживать и на других уровнях - с тем, чтобы иметь возможность сделать затем (в главе седьмой) некоторые обобщения.

\section{Cпособш выратенит ндеологтчестог точтек зрения}

Исследование проблемы точек зрения в плане идеологии, как уже говорилось, в наименьшей степени поддается формализации.

Существуют специальные средства выражения идеологической позиции. Таким средством являются, например, так называемые -постоянные әпитетые в фольклоре; действительно, появляясь вне зависимости от конкретвой ситуадии, они свидетельствуют прежде всего о каком-то определенном отношении автора к описываемому объекту.

${ }^{11}$ См. $о 6$ әтом подробнее ниже (с. 142 и сл.). 
Hапример:

Говорил с о 6 а к а Калин царь да то таковы слова:

- Ай же старыя казак да Илья Муромец!

- не служи-тко ты к нязю Владымиру.

- Да служи-тко ты с о 6 а к е ца́рю Калину12.

Любопытво привести пример использования постоянных эпитетов в более поздних текстах. Вот как пипет, например, в XIX веке автор исторического исследования о выговских старообрядцах в ТТрудах Киевской Духовной академии - естественно, с позиции официальной православной церкви:

...по смерти предводителя Авдрея все выговцы... приступили к Симиону Дионисьевичу и стали умолять его - да будет вместо брата своего Даниилу помощвиком веле н и м - ц р к о в о го предстоятельства ${ }^{13}$.

Таким образом, автор передает речь выговцев, во вкладывает в их уста эпитет («мнимов), который, конечно, соответствует не их, а его собственной точке зрения, выражая его собственную идеологическую позицию. Это не что иное, как тот же постоянный әпитет, какой имеем в фольклорных произведениях.

Сp. в этой связи также написание слова «Бог» в старой орфографии с прописной буквы во всех случаях - независимо от того, в каком тексте встречается это слово (например, в речи атеиста, сектанта или язычника). Аналогично в древнерусских текстах это слово могло писаться под титлом ( $₫ \overrightarrow{\bar{z}} \vee)$, как писались вообще nоmina sacra, т.е. слова со священным значением, даже и в том случае, когда имелся в виду бог языческий, а не христианский Бог.

Будучи возможен в прямой речи самого характеризуемого лица, постоянный әпитет не относится к речевой характеристике говорящего, но является признаком непосредственно идеологической позиции автора.

Однако с п е ц и а л в н е средства выражения идеологической точки зрения, естественно, крайне ограничены.

Нередко идеологическая точка зрения выражкается в виде той или нной речевой (стилистической) характеристики, т.е. фразеологи-

12 См.: Гильфердннг, II, с. 33 (ㄷ 75).

13 Cм.: Барсов, 1866, с. 230. 
ческими средствами, однако в принципе она отнюдь не сводима к характеристике такого рода.

Полемизируя с теорией М.М.Бахтина, утверждающего «полифонический характер произведений Достоевского, некоторые исследователи возражали, что мир Достоевского, напротив, «поразительно единообразен 14 . Думается, что сама возможность такого расхождения мнений обусловлена тем, что исследователи рассматривают проблему точек зрения (т.е. композиционную структуру произведения) в разных аспектах. Наличие различных идеологических точек зрения в произведениях Достоевского, вообще говоря, несомненно (әто убедительно показал Бахтив) - однако это различие точек зрения почти никак ве проявляется в аспекте фразеологической характеристики. Герои Достоевского (как это неоднократно отмечалось исследователями) говорят очень однообразно, причем обыкновенно тем же языком, в том же общем плане, что и сам автор или пассказчик.

В том случае, когда различные идеологические точки зрения выражаются фразеологическими средствами, встает вопрос о соотношении плана идеологии и плана фразеологии ${ }^{15}$.

Coornomente нланя неологих и плана фрезеалогии

Различные «фразеологические признаки, т.е. непосредственно лингвистические средства выражения точки зрения, могут употреблятъся в двух функциях. Во-первых, они могут употребляться для х а р а к т е и с т и к того лица, к которому относятся данные признаки; так, мировоззрение того или иного лица (будь то персонаж или сам автор) может определяться путем стилистического анализа его речи. Во-вторых, они могут быть употреблены для конкретного а д р с о в а и я в тексте к той или иной точке зрения, используемой автором, т.е. для указания некоторой конкретной позиции, которая используется им при повествовании; ср., например, случаи несобствевно-прямой речи в авторском тексте, со всей определенностью указывающие на использова-

14 См.: Волошин, 1933, с. 171.

150 выражении идеологической точки зрения при помощи временно́ рактеристики и о соотношении соответствующих планов см. ниже (с. 94-95). 
ние автором точки зрения того или иного персонажа (см. подробнее ниже).

В первом случае речь идет о плане идеологии, т.е. о выражении определенной идеологической позиции (точки зрения) через фразеологическую характеристику. Во втором случае речь идет о плане фразеологии, т.е. о собственно фразеологических точках зрения (әтот последний план будет детально рассмотрен нами в следующей главе).

Укажем, что первый случай может иметь место во всех тех видах искусства, которые так или иначе связаны со словом; в самом деле, и в литературе, и в театре, и в кино употребительна речевая (стилистическая) характеристика позиции говорящего персонажа; вообще сам план идеологии является общим для всех әтих видов искусства. Между тем второй случай является специфическим для литературного произведения; таким образом, план фразеологии ограничен исключительно областью литературы.

При помощи речевой (в частности, стилистической) характеристики может происходить ссылка на более или менее конкретную индивидуальную или социальную позицию ${ }^{16}$. Но, с другой стороны, таким образом может происходить ссылка на то или иное мировоззрение, т.е. какую-то достаточно абстрактную идеологическую позицию ${ }^{17}$. Так, стилистический анализ позволяет выделить в •Евгении Онегине два общих плана (каждый из которых соответ-

16 В әтом аспекте интересно исследовать заголовки стационарных рубрик в газетах (имектсл в виду стандартные ановсы типа /Нам пипут», Нарочно

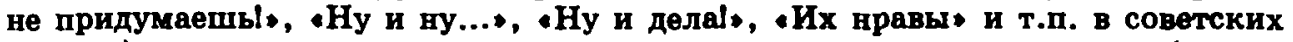
газетах), т.е. то, с точки зревия какого социального типа ови даљотся (внтеллигент, бравы й вонн, старый рабочий, певсяовер п т.П.); такое исследование может быть достаточно показательно для характеристики того или иного периода в жизни данного общества.

Ср. также различные тексты обълвлевия о курении в ресторане $\$ нас не

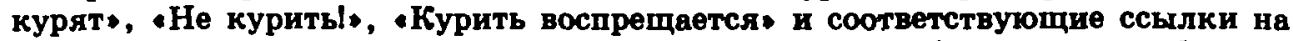
различные точки зрения, которые при этом происходят (точка зрения безличной администрации, милиции, метрдотеля и т.д.).

17 В плане соотношения мировоззревия и фразеологии показательна борьба после революдии с рядом слов, которые ассодиировались с реакционной идеологией (см.: Селищев, 1928), или, с другой стороны, борьба Павла I со словами, звучащими для вего как символы революции (см.: Виноградов, 1938, с. 193-194; Скабичевский, 1892; характөрен исторический анекдот, сообщаемый П.А.Вяземским: статс-секретарь Нелөдивский был удалөн за то, что употребил в разговоре слово представитель:- см.: Вяземский, 1929, с. 79). Ср. в әтой связи разнообразные социально обусловленные табу. 
ствует особой идеологической позиции): «розаический (бытовой) и «романтический , или точнее: ‘романтический и фнеромантический 18 . Точно так же в ЖЖитии протопопа Аввакума выделяются два плана: *библейский и *бытовой («небиблейский॰) ${ }^{19}$. В обоих случаях выделяемые планы параллельны в произведении (во если в Евгении Онегине әтот параллелизм используется для снижения романтического плана, то в «Житии Аввакума он используется, напротив, для возвышения бытового плана).

18 См.: Лотмan, 1966, c. 13 passim.

19 Cм.: Виноградов, 1923, с. 211-214. 


\section{2 „Точки зрения“ в плане фразеологии}

Различие точек зрения в художественном произведении может проявляться не только (или даже не столько) в плане идеологии, но и в плане ф р а з е о л о г и и, когда автор описывает разных героев различным языком или вообще использует в том или ином виде элементы чужой или замещенной речи при описании; при әтом автор может описывать одно действующее лицо с точки зрения другого действующего лица (того же произведения), использовать свою собственную точку зрения или же прибегать к точке зрения какого-то третьего наблюдателя (не являющегося ни автором, ни непосредственным участником действия) и т.д. и т.п. Необходимо заметить при этом, что в определенных случаях план речевой характеристики (т.е. план фразеологии) может быть е д и н с т в е н следить смену авторской позиции.

Процесс порождения произведения такого рода можно представить следующим образом. Положим, имеетя ряд свидетелей описываемых событий (в их числе может быть сам автор, герои произведения, т.е. непосредственные участники повествуемого события, тот или иной посторонний наблюдатель и т.п.) и кажддый из них дает собственное описание тех или иных фактов - представленное, естественно, в виде монологической п р я м о й $\mathbf{p}$ ч и (от первого лица). Можно ожидать, что әти монологи будут различаться по своей речевой характеристике. При этом сами факты, описываемые разными людьми, могут совпадать или пересекаться, определенным образом дополняя друг друга, эти люди могут находиться в тех или иных отношениях и, соответственно, описывать непосредственно друг друга и т.д. и т.п.

Автор, строящий свое повествование, может пользоваться то тем, то другим описанием. При этом описания, данные в форме прямой речи, склеиваготя и пе ре в о д тся в п л а н а в т о р с к й р е и. Тогда в плане авторской речи происходит определенная смена позиции, т.е. переход от одной точки зрения к другой, выражающийся в различных способах использования ч у о го с л в а в авторском тексте 1 .

1 Конкретная форма әтого использования завискт от степени авторского участия при обработке чужого слова (см. ниже). 
Приведем простой пример подобной смены позиций. Положим, начинается рассказ. Описывается герой, находящийся в комнате (видимо, с точки зрения какого-то наблюдателя), и автору надо сказать, что в комнату входит жена героя, которую зовут Наташей. Автор может написать в этом случае:

a) *Вошла Наташа, его жена»;

б) «Вошла Наташа ;

в) เНаташа вошла".

В первом случае перед нами обычное описание от автора или постороннего наблюдателя. В то же время во втором случае имеет место в у т рен н й мо н о лог, т.е. переход на точку зрения (фразеологическую) самого героя (мы, читатели, не можем знать, кто такая Наташа, но нам предлагается точка зрения не внешняя, но внутренняя по отношению к воспринимающему герою). Наконец, в третьем случае синтаксическая организация предложения такова, что не может соответствовать ни восприятию героя, ни восприятию абстрактного постороннего наблюдателя; скорее всего, тут используется точка зрения самой Наташи.

Здесь имеется в виду так называекое чактуальное членение предложения, т.е. соотнотение вданного и инового в организации фразы. Во фразе «Вошла Наташа слово «вопла представляет д а н н о е, выступая в роли логического субъекта предложения. а слово «Наташа - н о о е, являясь логическим предикатом. Построение фразы, таким образом, соответствует последовательности восприятия наблюдателя, находящегося в комнате (который сначала воспринимает, что к т о т о вошел, а поток видит, что этот « кто-то - H а т а II a).

Между тем во фразе «Натапа вошла» д а в н о е выражается, напротив, словом «Наташа», а в о в е - словом «вопла». Фраза строится, таким образом, с точки зрения человека, которому прежде всего дано, что описывается поведение Наташи, а относительно бо́льтую информадию несет тот факт, что Наташта именно в о ш л а, а не сделала что-либо иное. Такое описание возникает прежде всего тогда, когца при повествовании используется точка зрения самой Натапи.

Переход от одной точки зрения к другой весьма нередок в авторском повествовании и зачастую происходит как бы исподволь, контрабандой - незаметно для читателя; ниже мы продемонстрируем это на конкретных примерах. 
В минимальном случае в авторской речи может использоваться всего о д н а точка зрения. При этом данная точка зрения может фразеологически не принадлежать самому автору, т.е. автор может пользоваться ч у ж й р еч ь ю, ведя повествование не от своего лица, а от лица какого-то фразеологически определенного рассказчика (иначе говоря, єавтор и чрассказчик не совпадают в этом случае). Если данная точка зрения не относится к непосредственному участнику повествуемого действия, то мы имеем дело с так называемым явлением с к а 3 а в наиболее чистой его форме $^{2}$. Классическими примерами здесь служат гоголевская «Шинель или новеллы Лескова ${ }^{3}$;тот случай хорошо иллюстрируют и рассказы Зощенко.

В других случаях точка зрения автора (рассказчика) совпадает с точкой зрения какого-то (одного) участника повествования (для композиции произведения в этом случае существенно, выступает ли в роли носителя авторской точки зрения главный или второстепенный герой4); это может быть как повествование от первого лица (Icherzählung), так и повествование от третьего лица. Но существенно, что данное лицо при этом является единственным носителем авторской точки зрения в произведении.

Для нашего анализа, однако, больший интерес представляют такие произведения, в которых присутствует н е к о лько то-

2 См. о сказе: Эйхенбаум, 1919; Эйхенбаум, 1927; Виноградов, 1926; Бахтин, 1963, с. 255-257. Как отмечают Бахтин (с. 256) и Виноградов (с. 27, 33), Б.М.Эйхенбаум, впервые выдөинувший проблему сказа, воспринимает сказ исключительно в виде установки на у с т у у р е ч ь, тогда как едва ли не более специфической для сказа является установка на ч уж ую p e q $\mathbf{b}$.

3 См. разбор у Б.М.Эйхенбаума в указанных выше работах. Характерны слова самого Лескова по әтому поводу: ППостановка голоса у писателя заключается в умении овладеть голосом и языком своего героя и не сбиваться с альтов на басы. В себе я старался развивать әто умение и достиг, кажется, того, что мои священники говорят по-духовному, нигилисты - по-нигилистически, мужики - по-мужицки, выскочки из них и скоморохи с выкрутасами и т.д. От себя самого я говорю языком старннных сказок и дерковно-народным в чисто-литературной речи... Все мы: и мои герои и сам я - и ме ем с в о й с о 6 с т в н н й гол ос. Он поставлен в каждом из нас правильно или, по крайней мере, старательно... Вот этот народный, вульгарный и вытурныи язык, которым написаны многие страницы моих работ, сочинен не мною, а подслушав у мужика, у полуинтеллигента, у красвобаев, у юродивых и свлтош, (см.: Фаресов, 1904, с. 273-274).

$\checkmark$ Ср. аналогичную постановку вопроса выше (с. 22-25). 
чек зрения, т.е. прослеживается определенная смена авторской позиции.

Ниже мы рассмотрим различные случаи проявления множественности точек зрения в плане фразеологии. Но прежде чем обратиться к данному явлению во всем его многообразии, мы попытаемся продемонстрировать возможность выявления различных точек зрения в тексте на сознательно ограниченном материале.

В наших интересах было бы выбрать по возможности более простой и легко обозримый материал, чтобы на относительно несложной модели иллюстрировать различные случаи игры фразеологических точек зрения в тексте. Наглядным материалом подобной иллюстрации, как мы убедимся непосредственно ниже, может служить рассмотрение употребления в ввторском тексте с о 6 с т в н ны х и м е и вообще различных н а и е н о в н и й, относящихся к тому или иному действующему лицу.

При этом нашей спедиальной задачей - как здесь, так и далее - будет акцентировать аналогии между построением художественного текста и организацией повседневной бытовой речи.

\section{Нанмевование как проблема точки зрения}

\section{Hanmeromarme - обндепной peщ, публицстическей mpose, атстоляріом танре - в свиза с троблемоі royku aperits}

Необходимо заметить, что смена авторской позиции, формально выражающаяся в использовакии элемектов чужой речи (в частности, наименоввний), никоим образом не является исключительным достоңнием х у д о ж е с в е н н о го текста. В равной мере она может присутствовать в практике повседневного (бытового) рассказа и вообще в разговорной речи; тем самым здесь также могут присутствовать элементы комдозиции - в том смысле, что говорящий, строя повествование (высказывание), может менять свои позиции, последовательно становясь на точки зрения тех или иных участников повествования или каких-то других лиц, не принимающих участия в действии. 
Приведем элементарный пример из практики повседневной диалогической речи.

Положим лицо $X$ беседует с другим лицом $Y$ о некоем третъем лице $Z$. Фамилия $Z$, допустим, «Иванов», зовут его «Владимир Петрович , но $X$ обычно зовет его - при непосредственном с ним общении - «Володей *, тогда как $Y$ обыкновенно называет его *Владимиром (при общении $Y$ и $Z$ ); сам же $Z$ может думать при этом о себе как о «Вове (скажем, это его детское имя).

В разговоре $X$ и $Y$ относительно $Z-X$ может называть $Z$ :

a) ВВолодей - в этом случае он говорит о нем со своей собственной точки зрения (точки зрения $X$ ), т.е. тут имеет место личный подход;

б) «Владимиром - в этом случаө он говорит о нем с чужой точки зрения (с точки зрения $Y$ ), т.е. он как бы принимает точку зрения своего собеседника;

в) «Вовой - и в этом случае он говорит о нем с чужой точки зрения (с точки зрения самого $Z$ ) - при том, что ни $X$, ни $Y$ не гользуются этим именем при непосредственном общении с $Z$.

г) Наконец, $X$ может говорить о $Z$ и как о «Владимире Петровиче - несмотря на то, что и $X$ и $Y$ в глаза называют его коротким именем. Этот случай не так уж редок (он же может быть и в более гростой ситуации, когда и $X$ и $Y$ называют его в глаза «Володей че - хотя каждый из них и знает о том, как его собеседник называет данного человека). В этом случае $X$ как бы становится на абстрактную точку зрения - точку зрения постороннего наблюдателя (не являющегося ни участником беседы, ни ее предметом), место которого не фиксировано.

д) В еще большей степени последний случай (точка зрения абстрактного наблюдателя, постороннего по отношению к данной беседе) проявляется тогда, когда $X$ называет $Z$ по фамилии («Иванов») - при том, что и $X$ и $Y$ могут быть коротко знакомы с $Z$.

Все эти случаи реально засвидетельствованы в русской языковой практике ${ }^{5}$.

5 Автор может предложить читателю проследить за собственной речью и речью своих знакомых в данном отношении. Нетрудно убедиться, что все пять описанных случяев весьма обыqны в диалогической реqи.

При этом то или иное использование собственных имен зависит не тольно от ситуации, но и от индивидуальных качеств говорящего. Об отношении к 
Совершенно очевидно, что принятие той или иной точки зрения здесь прямо обусловлено отношением $k$ человеку, служащему предметом разговора ${ }^{6}$, и выполняет существенную стилистическую функцию.

Подобное же употребление личных имен характерно и для публицистической прозы. Здесь нельзя не вспомнить прежде всего известный случай с именованием Наполеона Бонапарта в парижской прессе по мере того, как он приближался к Парижу во время своих «Тта дней . Первое сообщение гласило: «К о р с и а н ск о ч у д о и щ е высадилось в бухте ЖЖуан.. Второе известие сообщало: «Л юд о д идет к Грассу. Третье известие: « У у р п а т р вошел в Гренобльн. Четвертое: Б о н а п а р т занял Лион». Пятое: «Н а п ле он приближается к Фонтенблон. И, наконец, шестое: $Е$ г и и п е р т о ск о е в л и ч е с т в о ожидается сегодня в своем верном Париже 7. (Замечательно, что наименования меняются здесь по мере приближения именуемото объекта к именуютему - подобно тому как величина объекта в перспективном опьте обусловлена расстаянием его от позиции наблюдателя.)

Подобный прием вообще в большей или меньшей степени типичен для газетного очерка или фельетона: то или иное отношение к герою проявляется прежде всего в том, как он именуется (в первую очередь - в именах собственных), а эволюция героя отражается в смене наименований.

Интересно обратить внимание также на определенную разницу позиций (по отношению к лицу, о котором идет речь), проявляющуюся в постановке инициалов до пли после фамилии. Ср.: АА.Д.Иванов" и, с другой стороны, АИванов А.Д."; последнее обозначение -

собственным именам как критерию индивидуальной характеристики см.: Успенский, 1966 , с. 8-9.

${ }^{6} \mathrm{Cp}$., например, определенную иронию в случае єв*, подчеркнутое уважение к лицу, о котором идет речь, в случае «г॰ и т.п.

7 См.: Тарле, 1941 , с. 348.

Сходные примеры нетрудно было бы найти и в наших газетах. Так, репортаж о матqе на первенство мира по шахматам в 1966 г. фигурировал под общим заголовком: Матч Т.Петросян - Б.Спасский॰. Однако, когда стала очевндной победа Петросяна, нейтральный заголовок сменился на более красноречивый: -Тигран Вартанович Петросян выиграл у Б.Спасского (•Вечерняя Москван за апрель 1966 г.). 
по сравнению с первым - несомненно, свидетельствует о более официальной позиции по отнотению к данному лиду.

Очень сходное употребление личных имен находим в мемуаpax Эренбурга (на произведениях которого вообще лежит большой отпечаток публицистического стиля). Эренбург, вводя новое лицо, обыкновенно характеризует его положение и указывает его фамилию и ивициалы, иными словами, ов как бы п р д с т а в я е т его читателю. Непосредственно вслед за этим - т.е. когда лицо уже представлено - он называет его по имени-отчеству, т.е. переходит на тот этап отношений, когда автор и данное лицо стали знакомыми (причем читатель может догадаться, что речь идет об одном и том же лице, только по совпадению имени и отчества с инициалами): * В мае ко мне неожиданно пришел сотрудник „Известий“ С. А. Р а е в ски й ... С те ф а в А рк а д ве в и ч сказал...*, «...Я пошел $к$ нашему послу В.С.Д о в а л е ск ом у ... В а ле ри ан С а вельевич превосходно знал Францию». Меня разыскал В. А. А н т о в о В О в с е е н к о... В л а д и и а А л к с а н д о в и а я знал с дореволюционных лет 8 .

Таким образом Эренбург как бы воспроизводит процесс знакомства, приобщая к нему читателя - помещая читателя на собственные позиции.

Подобное различие точек зрения особенно наглядно в том случае, когда имена, представляющие противоположные точки зрения, сталкиваются в о д в о й ф р а е. Ср. традиционную форму начала русских челобитных или вообще писем к высокопоставленному лицу:

Государи Борису Ив ановичу бъет челом твоей государевы арзамаския вотчины села Екшени последний сирота твой крестья ни иец Терешк о Осипов

Здесь в одной фразе противопоставлены точки зрения двух разных людей - отправителя и получателя сообщения (в данном случае: челобитной), причем имя получатедя сообщения дано с точки зре-

8 См.: Эренбург, II, с. 331,555 passim.

9 Из челобитной боярину Б.И.Морозову (см.: Хозяйство В.И.Морозова..., № 26). 
ния его отправителя, а имя отправителя сообщения дано, напротив, с точки зрения получателя: наименование боярина Бориса Ивановича Морозова дается с позиции отправителя челобитной (его крестьянина Т.Осипова), в наименоввнии же Терентия Осипова представлена позиция получателя челобитной (Б.И.Морозова).

Такое противопоставление точек зрения отправителя и получателя сообщения является непременным этикетом в подобной ситуации, причем может соблюдаться на всем протяжении челобитной. Ср.:

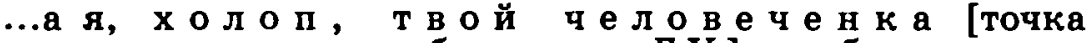
зрения получателя сообщения. - Б.У.], у тебя, г о с у д а p я [точка.зрения отправителя сообщения. новой, не отписать к тебе, г о с у д р ю [точка зрения отправителя сообщения. смел ${ }^{10}$.

Отметим как особенно характерные для приведенных случаев формы уменьшительности при наименовании отправителя сообщения. Функционально эти формы выступакот как этикетные формы вежливости: возвеличивание адресата происходит за счет самоумаления (самоуничижения) адресанта, т.е. говорящего или пишущего. (Аналогичный способ образовавия форм вежливости известен, между прочим, и в других языках, например, в японском и китайском ${ }^{11}$.)

При этом формы уменьшительности могут распространяться на все вообще относящееся к данному адресяну, т.е. происходит в каком-то смысле согласование по уменьшительности ${ }^{12}$. С этим непосредственно связано и употребление уменьшительных форм в значении форм вежливости или просьбы в современной русской разговорной речи (ср.: ‘У мевя к вам д е л ц ц е», -Дайте, пожалуйста,

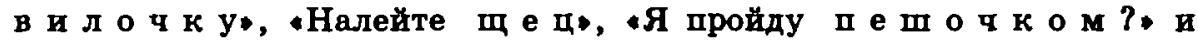
т.п.; при этом формы типа "пешочком" или «щец", конечно, не могут иметь значения уменьшительности в собственном смысле (характерно отсутствие уменьшительной формы в именительном падеже у последнего слова и наличие ее только в партитивном «втором родительном•, особенно употребительном вообще при обращениях).

${ }^{10}$ См.: Хозяйство Б.И.Морозова..., № 152.

11 См.: Эрберг, 1929, с. 172; Поливанов, 1931, с. 164 (примеч. 1).

12 См. примеры в кн.: Булаховский, 1950, с. 151. 
Еще пример такого же рода (начало письма опричного думного дворянина Василия Григорьевича Грязного-Ильина царю Ивану IV Васильевичу из крымского плена):

Госуд а ю ц а ю и великому кня И в а у В а си лье вич ю в с а Р у си и [точка зрения отправителя сообщения. - $5 . У$.$] бе д ны й$ холоп т вои полоняник В а сюк Гря з н о й плачетца ${ }^{13}$.

Здесь характерны не только уменьшительная форма собственного имени отправителя письма (Васюк), но и личное местоимение (mвои), с несомненностью свидетельствующие об использовании в данном случве точки зрения того, кому адресовано письмо, - Ивана Грозного.

Естественно, здесь следует учитывать ище и определенные социальные нормы наименования, имеющие абсолютный, а не относительный характер, т.е. сословное звачение того или иного способа наименования (так, полное имя и отчество на -ич в России XVI-XVIII веков являлось честью, на которую не все имели право). Нам, однако, важен в данном случае именно относительный характер наименования, обусловленный местом в процессе коммуникации. Так, когда представитель высшей аристократии обращается к еще более высокому по социальному положению лицу (например, князь к царю), он пишет так же, как пишет простой холоп, обращаясь к своему барину ${ }^{14}$; но таким же образом обращается, например, и учитель к отцу своего ученика ${ }^{15}$. Путешественник Олеарий специально отмечал, что и русский великий князь, когда обращается к кому-либо, также пользуется уменьшительными именами ${ }^{16}$.

Мы можем заключить, следовательно, что рассматриваемая особенность относится $\boldsymbol{k}$ специфике не столько общественвого положения адресанта по отношению к адресату (хотя и оно, разуме-

${ }^{13}$ См.: Иван Грозный, 1951, с. 566.

14 См.: Булаховский, 1950, с. 149.

15 См.: Мордовцев, 1856, с. 25.

Подобные формы при обращении были приняты до XVIII века, когда они были запрещены специальным указом Петра I от 20 декабря 1701 года (.O писании людям всякого звания полных имен своих с прозваниями во всяких бумагах частных и в судебные места подаваемых»). См.: Дементъев, 1969, с. 95.

${ }^{16}$ См.: Олеарий, 1906, с. 195. 
ется, весьма существенно), сколько вообще эпистолярного стиля; иначе говоря, подобное использование разных точек зрения обусловлено здесь требованиями вежливости, принятыми при написании обращения, которые и предписывают данный прием ${ }^{17}$.

Ошибочно было бы рассматривать этот прием как архаический, приписывая его исключительно специфике старинного эпистолярного стиля. Совершенно аналогичное столкновение противоположных точек зрения (отправителя и получателя сообщения) в одной и той же фразе нетрудно обнаружить и сегодня - в некоторых специальных жанрах. Ср., например, достаточно обычную разумеется, при определенных отношениях - форму надписи при подарке или посвящении (книги, картины и т.д.): Дорогой Берте Яковлевне Грайниной от ее Илюши Б л а з н о в а». Можно сослаться такж́ке на распространенную форму в разного рода заявлениях, надписях на конвертах и т.п.: "Андрею Петровичу Иванову от Сергеева Н.Н.», где обозначения адресата и отправителя противопоставляются как по признаку полноты наименования, так и по признаку расположения имени и отчества по отношению к фамилии ${ }^{18}$.

Здесь - опять-таки в одной фразе - имеет место точно такое же столкновение различных точек зрения, какое мы наблюдали выше $\mathbf{1 9}^{19}$.

17 Английский купец Джон Меррик в письме русскому царю 1603 г. подписался -holop tvoi hospodarev to the end of my days (см.: Александренко, 1911, с. 200). Здесь особенно очевиден переход на точку зрения адресата: слова «холоп Т в о й господарев», с местоименной формой 2-го лица, даны на языке адресата (в транскрипции), тогда как продолжение фразы - to the end of my days - двется снова по-английски (на языке адресанта) и, соответственно, от первого лица.

${ }^{18}$ Ср. выппе, с. 35-36, о стилистическом звачении при выборе данной позищии.

19 Любопытный и до известной степени парадоксальный прием последовательного использования чужой точки зрения в әпистолярном тексте находим в письме матери А.В.Сухово-Кобылина (М.И.Сухово-Кобылиной) к своей дочери, сестре драматурга, датируемое июнем 1856 г. (см.: Сухово-Кобылин, 1934, с. 204-206). Отправитель письма постоянно называет здесь своего сына - ‘братом*, последовательно используя таким образом точку зрения своего адресата. 


\section{Накменованте как проблема топाки зрения в худохественной трозе}

Выше мы приводили примеры использования различных точек зрения - которые при этом проявляются исключительно в употреблении тех или иных наименований - в бытовой речи, эпистолярном стиле, газетной публицистике и произведениях публицистического жанра. Но совершенно аналогично могут строиться и произведения художественной литературы, к рассмотрению которых мы сейчас переходим.

Действительно, очень часто в художественной литературе одно п то же лицо называется различными именами (или вообще именуется различным образом), причем нередко эти различные наименования сталкивағотся в одной фразе или же непосредственно близко в тексте.

Приведем примеры:

Несмотря на огромное богатство г а ф а Б е з у х о в а, с тех пор, как $\Pi$ ь е р получил его и получал, как говорили, 500 тысяч годового дохода, он чувствовал себя гораздо менее богатым, чем когда он получал свои 10 тысяч от покойного графа (*Война и мир* - Толстой, T. $X$, c. 103).

По окончании заседания великий мастер с недоброжелательством и иронией сделал Бе з у х ов у замеqание о его горячности и о том, что не одна любовь к добродетели, но и увлечение борьбы руководило им в споре. $\Pi$ в е $p$ не отвечал ему... (там же, т. X, с. 175).

Лицо его [Федора Павловича Карамазова. - Б.У.] было окровавлено, но сам он был в памяти и с жадностью прислушивался к крикам Д м и т р и я. Ему все еще казалось, что Грушенька вправду где-нибудь в доме. Д м и т р и й Ф е д о р о в и ч ненавистно взглянул на него уходя (‘Братья Карамазовы* - Достоевский, т. XIV, с. 129).

Совершенно очевидно, что во всех этих случаях имеет место использование в тексте не с к о л ь и х точек зрения, т.е. автор использует разные позиции при обозначении одного и того же лица. В частности, автор может использовать при этом позиции тех или 
иных действующих лиц (того же произведения), которые находятся в различных отношениях к называемому лицу.

Если мы знаем при этом, как называют другие персонажи данное лицо (а это нетрудно установить путем анализа соответствующих диалогов в произведении), то становится возможным формально определить, ч в я точка зрения используется автором в тот или иной момент повествования ${ }^{20}$.

Так, например, в •Братьях Карамазовых Достоевского рвзличные лица называют Дмитрия Федоровича Карамазова следующим образом 21 :

а) Д м т р и й К а р а а з в - так, например, его называют на суде (прокурор), так и сам он о себе иногда говорит;

б) бр т Дмитрий или брат Дмитрий Фе д о р о и ч - так называют его Алеша и Иван Карамазовы (при непосредственном с ним общении или же говоря о нем в третьем лище);

в) М и т я, Д м и т р й - они же, а также Ф.П.Карамазов, Грушенька и т.п.;

г) М и т н в к а - так его именует городская молва (ср., например, разговоры о нем семинариста Рвкитина или диалоги в публике на суде);

д) Д м и т р и й Ф е д о р в и ч - это нейтральное наименование, не относящееся специяльно к перспективе какого-либо конкретного лица; можно сказать, что это наименование безлично.

При этом автор в своем повествовании - т.е. уже непосредственно в а в т о с к о й речи - может называть Д.Ф.Карамазова всеми этими именами (кроме, пожалуй, предпоследнего случая); иначе говоря, описывая действие данного героя, автор может ме-

${ }^{20}$ Иногда это можно установить, исходя из общих соображений. Так, m-lle Bourienne в «Войне и мире», как правило, не называется в авторском тексте по имени-отчеству, а просто m-lle Bourienne, и это отвечает тому, как $к$ ней обращаются князь Николай Андреевич Болконский и члены его семьи. Однако, сообщая о том, что княжна Марья вынуждена была извиниться перед $\mathrm{m}$-lle Bourienne, Толстой пишет: ‘Княжна Марья просила прощения у Амалии Евгеньевны" (т. X, с. 301). Можно предположить, что здесь используется точка зрения слуг или даже конкретно Филиппа-буфетчика (см.: Виноградов, 1939, c. 177), для которых m-lle Bourienne предстает как Амалия Евгеньевна (или -Амалия Карловна - Толстой путвется в ее имени-отчестве и передает его по-разному).

21 Имеются в виду высказывания данных лиц, представленные в романе в форме прямой речи. 
нять свою позицию, используя точку зрения то того, то другого лица. Характерно при этом, что в начале прокзведения (и очень часто в начале новой главы) автор называет его преимущественно «Дмитрием Федоровичем॰, как бы становясь при этом на точку зрения объективного наблюдателя; лишь после того, как читатель достаточно познакомился ${ }^{22}$ с героем (т.е. после того, как Д.Ф.Карамазов оказался представленным читателю), автор находит возможным говорить о нем как о «Мите 23. Весьма показательно при этом, что, когда автор употребляет имя Митя в начале произведения - в первый раз после того, как Д.Ф.Карамазов предстает перед читателем, - Достоевский считает нужным взять это имя в кавычки (т. XIV, с. 95), как бы подчеркивая тем самым, что он говорит в данном случве не от своего лица. И в дальнейшем Достоевский говорит о Д.Ф.Карамазове то с точки зрения Алеши, к которой он особенно чвсто относится («брат Дмитрий ), то с более абстрактной точки зрения какого-то близкого Дмитрию Федоровичу человека (•Митя ) и т.п.

Использование той или иной точки зрения при наименовавии действующих лиц может выступать у Достоевского как вполне осознанный художественный прием. Показательно в әтом плаве начало повести «Слабое сердце»:

Под одной кровлей... жили два молодые сослуживца, Аркадий Иванович Нефедевич и Вася Шумков. Автор, конечно, чувствует необходимость объяснить читателю, почему один герой назван полным, а другой уменьшительным именем, хоть бы, например, для того только, чтоб не сочли такой способ выражения неприличным и отчасти фамильярным. Но для этого было бы необходимо предварительно объяснить и чин, и лета, и звание, и должность, и, ваковец, даже характеры действующих лид... (Достоевский, т. II, с. 16).

В дальнейшем оказывается, между прочим, что чин, возраст, звание и,должность обоих героев более или менее совпадают; таким образом, различие в их наименовании обусловлено, видимо, исключительно перспективой описания - той точкой зрения, кото-

22 Тут прямая аналогия с обрядом знакомства и переходом на коротқие нмена в обычной бытовой практике.

23 Подробнее об әтом приеме см. ниже, в разделе, посвященном рамкам художественного произведения (глава седьмая); ср. там же типологические аналогии с изобразительным искусством. 
рую использует автор. Отметим, кстати, что оба героя называют друг друга уменьшительными именами (Аркаша, Вася): следовательно, указанное различие характеризует именно особую точку зрения рассказчика.

\section{Иллострация: аналхз наменованй Наполеона в *Boйпе п мире* Толстого}

В аспекте всего сказанного выше о наименованиях как проблеме точки зрения веоьма показателен анализ наименований Наполеона Бонапарта - как в речи действующих лиц “Войны и мира», так и в авторском тексте 24 . Мы остановимся подробнее на этом анализе с тем, чтобы показать возможность обнаружения некоторых композиционных закономерностей в организации всего произведения в целом - на ограниченном материале наименований.

Надо заметить вообе, что отношение (русского общества) к называнию Наполеона проходит через весь роман. Эволюция отношения к наименованию Наполеона отражает эволюцию общества в отношении к самому Наполеону, а эта последняя несомненно составляет одну из сюжетных линий «Войны и мира».

Проследим коротко - по основным этапам - эту эволюцию. ,

Наполеона называют «Buonaparte (подчеркивая его нефранцузское происхождение) в 1805 году в салоне Анны Павловны Шерер; но заметим, что князь Андрей зовет его «Bonaparte (без u) (т. IX, c. 23), а Пьер - в противоположность всему обществу - все время говорит о нем как о Наполеоне 25 .

Далее, после занятия французами Вены, состоится знаменательное высказывание Билибина о Наполеоне:

- Но что́ за необычайная гениальность - вдруг вскрикнул князь Андрей, сжимая свою маленькую руку и ударяя ею по столу. - Й что́ за счастие этому человеку!

24 Отдельные замеqания в әтой связи см.: Виноградов, 1939.

25 За одним только исключением: начиная о нем разговор, Пьер однажды называет его Бонапартом (т. IX, с. 23).

В отношении исторической достоверности әтого феномена ср., между прочим, свидетельство П.Вяземского, относящееся ко времени войны 1806 г.: •немногие называли его тогда Наполеоном (см.: Вяземский, 1929, с. 171). 
- Buonaparte? - вопросительно сказал Билибин, морща лоб и этим давая чувствовать, что сейчас будет un mot. - Buonaparte? - сказал он, ударяя особенно на и. Я думаю, однако, что теперь, когда он предписывает законы

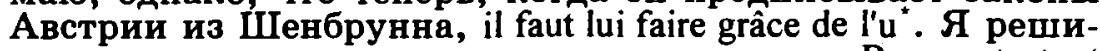
тельно делаю нововведение и называю его Bonaparte tout court $^{* \star}$ (т. IX, c. 191).

Несколько ниже, в разговоре князя Долгорукова с князем Андреем и Борисом Друбецким, мы опять сталкиваемся с проблемой называния: от Наполеона получено письмо к императору, и наш двор в затруднении, как ему адресовать ответ («ежели не консулу, само собою разумеетс, не императору, то генералу Буонапарту , - предлагает Долгоруков); в конце концов останавливаются по предложению Билибина на обращении - Главе французского правительства, au chef du gouvernement français (т. IX, с. 307).

Там же мы узнаем о шутке Билибиня, предложившего адресовать: уз ур патору и врагу рода человечес к о г о». С этой шуткой мы встретимся снова в письме Билибина к князю Андрею (написанном уже после Аустерлицкого сражения) (т. X, с. 96).

Далее, после успехов Наполеона, русский и французский императоры должны встретиться в Тильзите, и мы присутствуем при знаменательном разговоре Бориса Друбецкого с некиим генералом:

- Je voudrais voir l e $\mathrm{grand}$ h o m m e ** - сказал он [Борис. -.$y$.$] , говоря про Наполеона, ко т о р о го$ о н д с и $\mathbf{~ п ~ о ~ р ~ в с е г д ~}$ в а з ы а $\pi$ Б у о н п а р те.

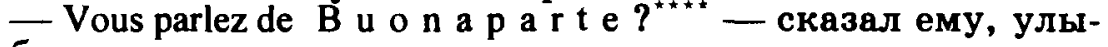
баясь, генерал.

Ворис вопросительно посмотрел на своего генерала и тотчас же понял, что это было шуточное испытание.

Mon prince, je parle de l' e m p e r u r $\mathrm{N}$ a p o l é o $\mathrm{n}^{+* \star}$, - отвечал он. Генерал с улыбкой потрепал его по плечу.

- Ты далеко пойдешь, - сказал он ему... (т. X, с. 139).

* Надо ето избавить от $u$.

** Просто Бонапарт.

*** - Я желал бы видеть в е лик ого че ловека.

**** - Вы говорите про Б о н а п а р т а ?

***** - Князь, я говорю об и п п раторе наполе оне. 
Итак, Бонапарт официально стал уже «великим человеком и *Наполеоном*, т.е. тем, чем он был уже - и отчасти перестал уже быть - для Андрея и Пьера. В то же время этого не может еще понять Николай Ростов (см., например, т. X, с. 140), причем Ростов, вероятно, представляет вообще точку зрения армии, противопоставленной штабу 26 .

А вскоре мы узнаем из письма княжны Марьи к Жюли Карагиной о том, что ‘Буонапарте... как кажется, еще только в Лысых Горах на всем земном шаре не признают ни ве ли ки м ч е л о в е к м, ни еще менее фран ц у ским и м пер а т о р о м (т. X, с. 233).

Так, мы становимся свидетелями эволюдии Наполеона в глазах русского общества 27 - и точно так же на наших глазах произойдет изменение к нему отношения в 1812 году. Ср. авторский пересказ общественного мнения (светских кругов) в начале войны 1812 г.: ^Они говорили, что без сомнения война, особенно с таким гением как Бонапарте (его опять называли Б о в а п а р т е), требует глубокомысленнейших соображений... (т. XI, с. 42).

В этой связи становится понятной функциональная смена авторской позиции, проявляющаяся в назывании Наполеона то одним, то другим именем - причем различные имена могут сталкиваться в одной фразе или находиться в непосредственной близости в тексте.

Например:

В 1809-м году близость двух властелинов мира, как называли Наполеона и Александра, дошла до того, что, когда Н а п ле о в объявил в этом году войну Австрии, то русский корпус выступил за-границу для содействия своему прежнему врагу Б о н а п а р т е против прежнего союзника, австрийского императора (т. $\mathrm{X}$, c. 152).

Очень часто внезапная смена имен Наполеона четко обозначает переход от одной точки зрения к другой:

Оба императора слезли с лошадей и взяли друг друга за руки. На лице $\mathrm{H}$ а п о л е о а а была неприятно притворная улыбка. Александр с ласковым выражением что-то говорил ему.

${ }^{26}$ Ср.: Виноградов, 1939, с. 158.

${ }^{27}$ Ср. далее к әтому же - т. XI, с. 127. 
Ростов, не спуская глаз... следил за каждым движением императора Александра и Бо н а п а т е (т. X, c. 1.17).

Описание тильзитской встречи здесь явственно дается сначала с безличной (или посторонней) точки зрения, а затем с точки зрения Ростова ${ }^{28}$.

Аналогично строится и описание разгоора Наполеона с кязаком Лаврушкой (т. XI, с. 133-134): «Но когда Н а п о л е о н спросил его, как же думают русские, победят они Б о в а п а р т a, или нет... (внезапный переход на точку зрения русских, в частности, самого Лаврушки, - типичный случай несобственнопрямой речи). Или (там же): «Переводчик передал эти слова Н а п о л е о н у... и Б о н а п а р т улыбнулся (точка зрения переводчика - или стороннего наблюдателя - мгновенно сменяется точкой зрения Лаврушки).

Ср. также следующую характерную фразу, где в обозначении Наполеона проявляется точка зрения не какого-либо конкретного человека, но вообще русского светского общества: «Градус политического термометра... был следующий: сколько бы все европейские государи и полководцы ни старались потворствовать Б о н а п а р т и ю... мнение наше на счет Бо н а п а р т и н не может измениться $($ т. $\mathrm{X}$, с. 87).

В других же случаях эта смена авторской позиции и переход на точку зрения участника действия не так очевидны, но мы можем о них догадываться по аналогии с только что сказанным. Примером может служить, в частности, сцена встречи Наполеона и князя Андрея, лежащего раненым на Аустерлицком поле: «Подъехавшие верховые были Н а п о л е о н, сопутствуемый двумя адъютантами. Б о н а п а р т е, объезжая поле сражения, отдавал последние приказания... (т. IX, с. 356). Можно думать, что и здесь имеет место переход с точки зрения постороннего наблюдателя на точку зрения князя Андрея, совпавший с изменением отношения князя Андрея к Наполеону 29.

Показательно подобное же столкновение имен во внутреннем монологе Андрея (уже значительно позже): «Лучший [из русских

$28 \mathrm{Cp}$. типологически аналогичное движение камеры в кино.

29 Ср. там же (т. IX, с. 357) внутренний монолог от лица князя Андрея ( „Он знал, что это был Наполеон - его герой, но в эту минуту Наполеон квзался ему столь маленьким, ничтожным человеком...*). 
генералов - Б.У.] Багратион, - сам Н а п о л е о н признал это. А сам 5 он а п а р те ! Я помню самодовольное и ограниченное его лицо на Аустерлицком поле (т. XI, с. 53). Когда князь Андрей говорит об оценке Наполеона, он называет его "Наполеоном" т.е. так, как нязывают его все вокруг в данный момент повествования; но, вспоминяя о времени Аустерлица, когда все. и в том числе и он сам, называли его Бонапартом, он говорит о нем как о « bонаптарте.

В связи со сказанным мы можем предполагать, какое функциональное изменение вызвала бы в том или ином случае замена имени Наполеона. Ср., например, описание положения войск в начале главы XIV 2-й части первого тома «ойны и мира: ‘Ежели бы Кутузов решился оставаться в Кремсе, то полут'растатысячная армия Наполеона отрезала бы его от всех сообшений... - пишет Толстой (т. IX, с. 206). Тут сказано - Наполеон», и мы можем думать, что эта фраза дается от лида самого автора, т.е. здесь представлено, по всей видимости, объективное описание стратегических возможностей. Но если бы мы заменили в әтой фразе имя «Наполеон • на ‘Бонапарт, фраза воспринималась бы, скорее, как рассуждение самого Кутузова (т.е. данное с его точки зрения).

Итак, на протяжении повествования мы становимся свидетелями изменения в наименовании Наполеона в русском обществе. Если в начале романа (особенно в первом томе) его почти повсеместно называют «Бонапартом*, то в третьем томе это имя встречается в речи действующих лиц уже очень редко (а если и встречается, то обычно в речи таких персонажей, как Лаврушика, Макар Алексеевич), а в четвертом уже не встречается и вовсе ${ }^{30}$. На этом фоне особенно значимы становятся отклонения: Пьер, который, как уже говорилось, называет его «Наполеоном*, в то время как все говорят о нем как о «Бонапарте», или, напротив, граф Растопчин, называюций его “Бонапартом", когда все вокруг называют его *Наполеоном* 31 .

Так происходит в речи участников повествования; но вместе с изменением наименования Наполеона в речи персонажей меняется оно и в а в т о р с к о й р е ч и. В первом томе “Войны и мира" Наполеон в большинстве случаев называется в авторской речи «Бо-

30 За одним-единственным исключением (т. XII, с. 282): Денисов, вспоминающий старые дни; можно думать, что именно ретроспекция и служит здесь оправданием данного выбора имени.

${ }^{31}$ См., например, т. X, с. 306; т. XI, с. 176. 
напартом"32; во втором томе имена "Бонапарт и "Наполеон* употребляются поровну; в третьем томе имя «Боняпарт употребляется в единичных случаях, а в четвертом - не употребляется вовсе.

Мы видим, таким образом, что автор в своем отношении к Наполеону как бы следует за обществом, которое он описывает.

\section{Cоотнопение \\ слова автора и слова героя \\ в тексте}

В вышеприведенных случаях совмещение различных точек зрения в тексте (как художественном, так и бытовом) иллюстрировалось на ограниченном материяле собственных имен или вообще наименований в авторском повествовании.

Мы можем сказать, что различие авторской позиции проявляется здесь в том, что в авторском тексте появляются $ә$ л е м е н ты чу жо го текст а - т.е. элементы речи, характерные то для одного, то для другого персонажв.

Эта общая формулировка может быть отнесена, разумеется, отнюдь не к одним только собственным именам. Использование элементов чужого текста, которые при этом могут принадлежать различным лицам, представляет собой основной способ выражения различных точек зрения в плане фразеологии.

Мы подходим здесь к рассмотрению различных возможностей передачи чужого текста (сочетания чужого и собственного авторского текста), и в частности к проблеме несобственно-прямой речи ${ }^{33}$.

Мы последовательно рассмотрим две возможности контаминации авторского текста («ввторского слова») и текста какого-то другого лица («чужого слова ):

a) видоизменение авторского текста под воздействием текста, принадлежащего не собственно автору, т.е. влияние чужого слова на авторское слово;

32 Если исключить случая использования в авторской речи точки зрения Пьера (см., например, т. IX, с. 65 и др.) и случаи цитирования высказываний, принадлежащих самому Наполеону, употребление имени «Наполеон в авторском тексте в первом томе ‘Войны и мира» сводится к отдельным случаям.

3 Фундаментальное исследование по проблемам использования чужого слова см. в кн.: Волошинов, 1929. 
б) видоизменение текста, принадлежащего не непосредственно самому автоғу, под воздействием авторской обработки, т.е. влияние авторского слова на чужое слово.

Под а в т о р м при этом здесь и далее понимается то лицо, которому принадлежит весь рассматривяемый текст. Этим лицом может быть как автор произведения, так и любой говорящий, высказывание которого составляет объект рассмотрения (и в речи которого могут наблюдаться элементы какого-то чужого текста).

В том же смысле можно противопоставлять «свое (т.е. авторское) слово и ччужо (по отношению к автору) слово.

\section{Влияние чужого слова на авторское слово}

Нанболее отчетлине случан нспользования чуххого слова в тексте

Случаи использования нужого слова вообще чрезвычайно часты и многообразны. Мы начнем с наиболее простых примеров.

Обращаясь опять к •Войне и миру , нетрудно убедиться, что подобные случаи очень часто осознаются Толстым и, как правило, выделяются в тексте курсивом (если это не инострвнный текст). ский):

Cp., например (курсив в данных ниже примерах всюду автор-

Анна Павловна кашляла несколько дней, у нее был грипn, как она говорила (грипn был тогда новое слово, употреблявшееся только редкими) (т. IX, с. 3).

- Остввьте, Борис, вы такой дипломат (слово дипломат было в большом ходу у детей...) (т. IX, с. 56).

Или разговоры Пьера с князем Андреем:

[Пьер:] - И вы... - Он не сказал, что вы, но уже тон его показывал... (т. IX, с. $35-36$; многоточие в прямой речи - Толстого).

[Пьер:] - И что ж, право... - Но он не сказал, что право (т. IX, c. 36). 
Замечательно, что точно так же - курсивом - выделяет Толістой те случаи, когда элементы чужой речи попадаются не в тексте автора, а в прямой речи действующих лиц. Например, из разговора Наташи с Борисом Друбецким:

- Борис, подите сюда, - сказала она... - Мне нужно сказать вам одну вещь.

- Какая же это одна вещь? - спросил он (т. IX, с. 53).

Иными словами, Толстой, спорадически пользуясь чужим словом, как бы считает необходимым специально подчеркнуть, что это слово ему не принадлежит, что оно заимствовано на время из чьей-то речи (причем так происходит и в авторском тексте, и в тексте, относящемся к персонажам).

O6ьединение точек зредия

pazmтанық в слохніо предлохсения. Несобственіо-прямая peris.

Более сложные случаи использования элементов чужого текста мы имеем в разнообразных формах так называемой «несобственно-прямой речи ${ }^{34}$, к непосредственному рассмотрению которой мы сейчас переходим.

Совмещение нескольких точек зрения возможно не только в пределах повествования, но и внутри одного предложения; это особенно характерно для устной речи, когда мы невольно становимся вдруг на точку зрения того, о ком рассказываем.

Классическим примером является здесь фраза Осипа в « Ревизоре Гоголя: «Трактирщик сказал, что не д а м в а м е с т в, пока не з а п л а т и т за прежнее (т. IV, с. 27) ${ }^{35}$. Два высказывания, принадлежащие различным говорящим - самому Осипу (который в данном случае выступает в качестве автора текста) и трактирщику, - объединены здесь в пределах одной фразы, причем каждое высказывание сохраняет свои грамматические признаки.

34 Эквиваленты термина ниесобственно-прямая речь в некоторых европейских языках: англ. «seemingly indirect style», нем. «die uneigentliche directe Rede. и отчасти «die erlebte Rede», франц. «le style indirect libre , исп. «estilo indirecto libro , польск. «mowa pozomie zależna*.

35 См.: Пешковский, 1935, с. 429. Этот пример цитируется и в кн.: Волошинов, 1929, с. 148 (примеч. 2). 
Ср. аналогичный Же случай:

Его Величество обратил его [Французского посланника. - -.У.] внимание на гревадерскую дивизию и церемониальный марш, и будто посланник никакого внимания не обратил и будто позволил себе сказать, что м ы у себя во Франции на такие пустяки не обращаем внимания (*Война и мир - Толстой, т. $\mathrm{X}$, с. 307$)$.

В обоих случаях представлена не прямая речь и не косвенная, но особое явление, называемое *несобственно-прямой речью .

В самом деле, если бы это была прямая речь, то не было бы союза «что॰: «Трактирщик сказал: „Не дам вам есть, пока не заплатите...“" *...посланник... позволил себе сказать: „Мы у себя во Франции...“".

Если бы әто была косвенная речь, было бы согласование в лице в главном и придаточном предложениях: Трактирщик сказал, что не д а с т н а м есть, пока не заплатим...», *...посланник ... позволил себе сказать, что о в и у себя во Франции.....

Очевидно, что в приведенных случаях имеет место ни то, ни другое, а с и н т з обоих явлений, т.е. совмещение текстов, принадлежащих разным авторам: самому говорящему и тому, п р о к о г о он говорит. Другими словами, в этих случаях наблюдается как бы скольжение авторской позиции, когда говорящий в процессе речи незаметно меняет свою позицию.

Иногда полагают, что несобственно-прямая речь в русском языке - явление новое, появившееся под влиянием французского языка ${ }^{36}$. Это мнение, однако, может быть опровергнуто ссылками на примеры из летописей (*рече же имъ Ольга, як о а з ъ уже мьстила е с м в мужа своего - из Ипатьевской летописи под 946 годом ${ }^{37}$ ), из фольклора (^Говорит Ставер сын Годинович. - Ч т о я с тобой сваечкой не игрывал/. ${ }^{38}$ ). Думается, что явление несобственно-прямой речи совершенно естественно в языке с развитыми формами гипотаксиса, будучи обусловленным характерной для речевой практики сменой авторской позиции.

Характерны пример несобственно-прямой речи мы находим в древнерусской «Повести о Митяе (по изложению Никоновской ле-

${ }^{36}$ См.: Булаховский, II, с. 444.

37 ПСРЛ, II, 1908, стлб. 47; Молотков, 1952, с. 21; там же и другие примеры. Ср. также: Лихачев, 1970, с. 134.

38 Рыбников, I, с. 210 (№ 30). 
тописи), где рассказывается о конфликте ннареченного митрополита. Михаила-Митяя (управляющего митрополией, но не возведенного в сан) и суздальского епископа Дионисия. Ср.:

И тако наречеввый митрополит Митяй посла $к$ Деонисию епископу Суждалскому, глаголя: „почто, пришед в град, ко мне не пришел еси поклонитися и благословитися, и сице не чествовал мя еси и пренебрег, якоже векоего от последних суща? не веси ли, кто есмь аз? в л а с т ь и м а м и в т е 6 е и во всей митрополии“. Деонисей же епископ Суждалскый, встав, иде к нему и, пришед, рече ему: „присылал еси ко мне, глаглля, яко власть им ам н а т е 6 е; но убо не имаши власти ва мне никоеяже..."39.

Если бы мы не знали контекста, то грамматически мы вправе были бы понять слова Дионисия -присылал еси ко мне, г л а голя, я ко в л а с т в и м а н а т е 6 е таким образом: ‘Ты присылал ко мне, говоря, что я (Дионисий) обладаю властью над тобой॰. На самом же деле фраза -власть имам на тебе॰ принадлежит не Дионисию, а Митяю, т.е. слова Дионисия означают следующее: -Ты присылал ко мне, говоря, что обладаешь надо мной властью.. Как видим, один и тот же текст может выражать как несобственнопрямую, так и косвенную речь, причем в зависимости от той или иной трактовки существенно меняется смысл высказывания.

Вышеприведенные случаи характеризуются прежде всего тем, что объединение различных точек зрения (соответственно - объединение текстов, принадлежащих разным лицам) происходит здесь внутри о д о й и т ой ж е ф р а 3 ы (такой фразой является при этом сложноподчиненное предложение) $\mathbf{4 0}^{\mathbf{0}}$.

Эти случаи относительно просты, так как нам ясны границы, где кончается текст, принадлежащий одному автору, и начинается текст, принадлежащий другому. Так, мы можем в каждой из приведенных фраз взять какие-то слова в кавычки и рассматривать данный случай как продукт случайной речевой интерференции, т.е. явления, относящегося к речи, а не к языку41. «рактирщик сказал, что „не дам вам есть, пока не заплатите... “*, «...посланник... позволил себе сказать, что „мы у себя во Франции...“».

${ }^{39}$ ПСРЛ, XI, 1897 , с. 37.

40 Ниже мы рассмотрим случаи объединения различных точек зрения в простом предложении.

41 О разграничении языка и речи, принятом в современном языкознании, см.: Соссюр, 1933. 
В этом смысле только что приведенные случаи объединяются с цитированными выше примерами из Толстого, поскольку и там границы чужого слова отчетливо даны во фразе, и нам легко проделать соответствующую операцию с кавычками (собственно говоря, курсив, которым выделяет Толстой элементы чужого текста, и является функциональным әквивалентом кавычек).

Кавычки представляют собой достаточно специфическое средство выражения в том смысле, что относятся исключительно к письменной речи ${ }^{42}$. Но в русском языке существуют особые слова, выполняющие функцию кавычек (в предложениях рассматриваемого типа), т.е. вводящие прямую речь и отмечающие вообще границу чужого текста: такую роль играют слова (частицы) «мол*, *де*, «десать». Ср., например, следующую фразу у Достоевского в «Бедных людях :

Заключил же он тем, что, д е с к а т, простите мою дерзость и мое неприличие, Макар Алексеевич (Достоевский, т. I, с. 90$)^{43}$.

Легко видеть, что, если убрать слово «дескать в приведенной фразе, перед нами будет случай несобственно-прямой речи, совершенно аналогичный обсуждавшимся выше примерам. Соответственно, мы вправе, вообще говоря, трактовать эти последние как эллиптические конструкции, возникшие в результате опущения слов

42 Применительно к устной речи соответствующая информация (т.е. обозначение границы чужого текста) может быть передана при помощи паузы, изменения интонации и тембра голоса и т.п.

43 Нижеследующий пример (взятый из доношения В.К.Тредиаковского в канцелярию Академии наук от 4 ноября 1753 г.) особенно наглядно иллюстрирует функциональную связь подобных слов с введением в текст әлементов прямой речи. .... г. советник Ломоносов... говорил г. асессору Тауберту... о своем председании пред ним и, следовательно, пред всеми старшими его в академической службе, именно ж: что понеже всемилостивейшая государыня пожеловала его советником за отличную его науку, то-де я потому первенствующий пред всеми профессор (Пекарский, II, с. 171). В әтом примере косвенная речь (начинаљщаяся со слов « что понеже...»), в которой о Ломоносове говорится в 3-м лице (ср. местоименную форму єего, встреqающуюся дважды) неожиданно переходит в прямую (ср. местоименную форму «я»). Знаменательно при әтом, что введение әлемента прямой речи (местоимения 1-го лица) сразу же обусловливает появление в тексте частицы «ден. Элиминация этой частицы из текста в данном случае невозможна без ущерба для грамматической правильности данной фразы. Мы видим, что соответствующая частица очень точно обозначает границы \&ужого слова. 
подобного рода, предполагая, что в более полном стиле они должны были бы иметь приблизительно следующий вид: «Трактирщик сказал, что, м о л, не дам вам есть...", "посланник... позволил себе сказать, что, д е, мы у себя во Франции.... и т.п. ${ }^{44}$. Такого рода фразы могут быть также отнесены к разновидности несобственно-прямой речи. При этом соответствующие слова (типа частиц "де*, «мол», "дескать в русском языке) можно рассматривать как своеобразные операторы, используемые для перевода прямой речи в авторскую речь (в самом деле, непосредственно в прямой речи употребление этих слов в обычном случае невозможно). Их можно было бы назвать «словами-кавычками или «цитатными элементами». Элементы такого рода встречаются и в других языках ${ }^{45}$.

Вслед за В.Н.Волошиновым, но в отличие от целого ряда исследователей, которые считают возможным объединять под термином * несобственно-прямая речь такие, например, явления, как внутренний монолог и т.П., и вообце самые разнообразные случаи использования «чужого слова, - мы употребляем термин *несобственно-прямая речь в узком смысле: для обозначения явления переходного между прямой речью и косвенной, т.е. такого явления, которое можно определенными операциями превратить (с той или иной степенью точности) как в прямую речь, так и в косвенную. Эти операции могут быть сформулированы на достаточно общем уровне: для перевода из несобственно-прямой речи в прямую речь это расстановка кавычек и опущение союзов, для перехода из несобственно-прямой речи в косвенную речь - это операпия согласования в грамматических формах ${ }^{46}$.

44 Следует оговориться, что, в отличие от кавычек, слова типа «де, «мол и т.п. могут употребляться в косвенной речи, т.е. и в тех случаях, когда имеет место грамматическое согласование форм в главном и придаточном предложении. Так, в принципе вољможны примеры: Трактирщик сказал, что, мол, не д а с т нам есть..., «...посланник позволил себе сказать, что, де, о н и у себя во Франции... (ср. в этой связи: Пешковский, 1935, с. 430). Подобные случаи могут рассматриваться как вторичные по сравнению с только что приведенными: функция соответствующих слов выступает здесь менее ярко.

45 См.: Якобсон, II, с. 130-131; Якобсон, 1972, с. 95-96.

46 При этом если в русском языке предполагается согласование в именных категориях (глагол в косвенной речи согласуется с именем в главном предложении в формах рода, лица, числа), то, например, в романо-германских языках необходимым условием является еще и согласование по времени (consecutio temporum). Следует заметить, что разные языки отличаются еще и по степени однозначности перевода прямой речи в косвенную (иначе говоря, по степени близости этих двух форм речи). Так, например, в русском языке в 
0бтединение

точек зрения

размнчных

в тростом предложеки.

Сочетание точек

зренда говоряцието

и слушанщего

В приведенных выше случаях несобственно-прямой речи объединение различных точек зрения производилось в пределах сложного (сложноподчиненного) предложения. Ниже мы рассмотрим случаи такого объединения непосредственно в простом предложении. В этот разряд могут быть отнесены, вообще говоря, и цитированные выше примеры спорадического употребления чужого слова во фразе у Толстого; но нас сейчас будут интересовать случаи более органичного соединения элементов «чужого и "своего текста во фразе.

Обратимся к примеру.

Толстой пишет в «Войне и мире»:

Князь Василий, занимавший все те же важные должности, составлял звено соединения между двумя кружками. Он ездил $\mathrm{k}$ m a bonne amie Анне Павловне и ездил dans le salon diplomatique de $\mathrm{m}$ a fille..." (т. XI, c. 128).

Вдесь характерно двукратное употребление местоимения первого лица та («моя») - при том, что речь, вообе говоря, идет о третьем лице! - со всей определенностью указывающее на использование в этих случаях точки зрения самого князя Василия.

Герой повести Ф.М.Достоевского «Игрок , обращаясь к Полине, говорит ей: «Я бы, на вашем месте, непременно в ы ш л а за-

ряде случаев подобный перевод может быть только приближенным. Например, прямую речь ХХоть бы поест мы передадим в косвенной речи примерно так: ‘Он сказал, что же л а л 6 ы поесть; фраза "как хорошо в косвенной речи получает вид: “Он сказал, что э то о ч е н х хорошо или Он в ост о ж е н н сказал, что ә то хорошо и т.П: Очевидно, что данное преобразование в этих случаях необратимо, т.е. мы не можем однозначно получить из фразы в косвенной речи исходную фразу в прямой речи. Между тем в латинском языке, так же как и в целом ряде других, перевод из прямой речи в косвенную характеризуется почти максимальной однозначностью (см.: Соболевский, 1948, с. 347 и далее; Волошинов, 1929, с. 151, а также с. 166 и далее).

" Своему достойному другу [букв.: моему. - Б.У.].

** В дипломатический салон своей дочери [букв.: моей. - B.У.]. 
муж за англичанина (т. V, с. 213). Он - мужчина - употребляет здесь глагольную форму женского рода (что, вообще говоря, противоречит всем законам русского языка) - потому, что, произнося эту фразу, он как бы становится временно на точку зрения своей собеседницы - на вашем месте - говорит он ей - и действительно становится в этот момент на ее место, что проявляется и лингвистически). Вырванная из контекста, эта Фраза может восприниматься только как принадлежащая женщиве.

Мы видим, что в одной и той же фразе (представляющей собой к тому же п ресто́ предложение) совмещено несколько точек зрения - или, иначе говоря, совмецены элемевты двух сфер речи: говоря щ е го и сл у ш а ше го. Можно сказать, что здесь имеет место вНутриязыковое дв уязы ч и е между тем и другим.

При этом чужое слово здесь более оргвнично входит в текст, будучи не так легко вычленимо, нежели в приведенных выше случаях несобственно-прямой речи. В самом деле, если мы и можем перевести элементы чужой речи в прямую речь (т.е. расставить кавычки), то со значительно больтей натяжкой - отнюдь не так легко, как в предыдущем случае ${ }^{47}$; тому же и сами границы чужого слова здесь не обозначены однозвачно (в отличие от приведенных выше примеров). В то же время перевести давную фразу в план косвенвой речи путем каких-либо заранее определенных операций и в в се н е в з м ж н о. Таким образом, подобная фраза не представляет случая несобственно-прямой речи в непосредственвом смысле слова ${ }^{48}$ : точки зрения слились здесь более тесно.

Следует заметить, что совмещение различных точек зрения в частности, точек зревия гово р щ е го и с $л$ у ш а ю ще г о очень часто в устной речи.

Так, именно этот случай имеет место, когда употребляют такой распространенвый в современной разговорной речи оборот, как Вы меня, конечно, извините». В подобных случаях говорящий как бы предвосхищвет оценку слушающего, ов становится на его (слушающего) точку зрения.

47 Эта относительно менышая легкость станет наглядной, если мы попробуек, прочтя данную фразу вслух, выделить в пей чужую прямую речь интонацией; в то же время в прнведенных выше случаях (несобственно-прямой речи) перевод в прямую речь вполне поддвется интонационному выделеник. Ср. выше, с. 53 (примеч. 42).

$48 \mathrm{Cp}$. определение несобственно-прямой речи выше, с. 54. 
Ср. подобный же переход от точки зрения говорящего к точке зрения собеседника в следующей характерной фразе (записанной в ситуации спора между торопящимся студентом и придирающимся к нему вахтером, который требует предъявить документ): Чего пристаете, не видите разве - человек спешитl - Человеком здесь называет себя сам говорящй, имея в виду, что вахтер должен был бы увидеть, что ччеловек спешит и войти в его, т.е. человека , состояние; говорящий, таким образом, как бы становится на позицию вахтерв (говоря о себе в третъем лице) и подсказывает ему правильную точку зрения. Совершенно так же объясняются и случаи, когда говорящий по отношению к себе самому употребляет неопределенно-личную форму - вапример, когда дающий говорит: -Бери, пока дают! или при обращении типа Кому говорят? (в этих случаях говорящий становится на точку зрения собеседника и говорит о себе, соответственво, - с его, собеседника, точки зрения - в нарочито безличном третьем лице множественного числа) ${ }^{49}$.

Можно заметить, что приведенные случаи использования чужого слова в бытовой речи более характерны для вульгарного стиля. Это не случайно, поскольку данны продесс представляет собой один из типичных путей әволюдии языка (пзменения значения слов) (ср., например, эволюцию значения слова наверное в русском языке, которое еще в начале этого века обозначало «наверняка», тогда как теперь употребляется в смысле "вероятно и даже возможно, т.е. в значении, в большоћ степеви противоположном предыдущему; можно видеть, что здесь произошел сдвиг от точкп зрения говорящего к точке эрения слушагощего). В то же время вульгарный стиль является, как правнло, более продвинутым в лингвистическом отношенни, т.е. тут обычно в первую очередь совершаготся те процессы, которые еще не затронули другие пласты языка ${ }^{50}$. Таким образом, понятно, что кменно в вульгарном стиле явления несобственво-прямой речи и вообще использования чужкого слова должны превалировать 51 .

49 Слода же относится и неправильный с точки зрения стилистических норм русского языка оборот « кушаю.. Считается, что про сөбя следует говорить \& зом, и здесь можно видеть пример использования чужой точки зрекия.

50 См. 06 әтом: Успенскии, 1969 , с. $499-500$.

51 Фразеологическое использование чужой точки зрения, в частности, обращение к точке зрения собеседника, нередко имеет иронический или издевательски. оттенок. Ср., например, нздевательское использование полонизмов в посланиях Ивана Грозного при обращеник к полякам или деятелям Литовской Русн, когда он говорит как бы от их имени, вкладывая в их уста нуж- 
В общем близкий случай совмещения речевых позиций можно видеть и тогда, когда мы говорим ребенку: "Какие мы красивыеl. Мы говорим это не только со своей точки зрения (с точки зрения говорящего), но и с точки зрения самого ребенка (слушающего) т.е. как бы от лица его самого, но вместе с тем и со своей собствевной точки зрения (поскольку мы вкладываем в его уста фразу, принадлежащую нам, а не ему), причем различные точки зрения (говорящего и слушающего) с о в м еш ены здесь, чтобы передать оттенок соучастия, неразделимости, характерный в отношении к маленькому ребенку 52 .

Вообще, разговаривая с маленьким ребенком (особенно не научившимся еще говорить), нам свойственно становиться на его точку зрения - что проявляется прежде всего в плане фразеологии; во многих ситуациях такое поведение является нормой. Действительно, очень многие фразы мы говорим от лица ребенка и его интонацией - как бы подсказывая ему, что говорят в той или иной ситуации. Так, обычно мы говорим, вапример: ‘Иди ко мне ва р уч к и*, а не «на руки», т.е. используем при этом не собствен-

ное ему содержание. Например, при обрапении к королю Баторию: ^Ино то давно ведомо, что ты 3 а в с п п аг н еш в на кровопролитство хрестьянскоеl . К гетману Ходкевичу: „Его же ты не зная, н е ц н о т н ы й [бесчестный - Б.У.] человек, похваляешь и т.п. (см.: Иван Грозный, 1951, с. 234, 272; ср.: Тамань, 1961, с. 200-201).

Аналогичное явление можно встретить в естественной диялогической речи, когда говорящий передразнивает собеседника, речь которого характеризуется какими-то специфическими признаками (например, акцентом, теми или иными дефектами и т.п.), произнося определенные слова на его (собеседника) речевой манер, т.е. как бы вкладывая при этом собственное содержание в чужие уста.

52 В целом ряде речевых ситуаций та же модель может вцступать и по отношению ко взрослому (в частности, когда подчеркивается снисходительное или ироническое отношение к тому или иному лицу, как бы уподобляөмое отношению к ребенку). Так, у Достоевского в • Бесах • Петр Степанович иронически говорит о своем отце: -МЫ, знаете, в карточки очень повадливы..." (т. X, с. 162), как бы вкладывая әти слова и в его уста; таким же образом говорит губернаторша Юлия Михайловна о Лизе: ^Я... хорошо знаю, какая на наших плечиках всевластная головка (т. X, с. 126). При әтом уменьшктельные формы вроде «карточки», плечики», «оловки», опять-таки, подчеркивают апелляцию к ситуации общения с ребенком.

Тот же, в общем, оттенок снисхождения выступает и в традиционном 06 ращении милиционера $к$ нарушителям порядка: •Граждане, давайте не бу. демl. 
ную точку зрения, а точку зрения ребенка (выраженную фразеологически); подобные примеры нетрудно умножить. Не менее характерно в этой связи и то, что в присутствии ребенка мы часто именуем друг друга с его точки зрения (можно сослаться в этой связи на довольно распространенную ситуацию, когда супруги называют друг друга *папа и *мама ).

\author{
Максимальная \\ ковцентрация \\ противостовmuиx тоqек \\ зрения в тексте: \\ случаи обьединения \\ различиых точек зрения \\ в одном и том же слове
}

Еще более парадоксальный случай объединения разных точек зрения представлен тогда, когда различные точки зрения объединяются в о д н о м и т о м ж е с л о в е. Этот случай, правда, характерен более для сферы речи, нежели для сферы языка, т.е. относится скорее $\kappa$ спорадической импровизации (непосредственному процессу порождения текста), чем к норме. В то же время этот случай имеет отношение и к литературным текстам.

Так, Ф.Ф.Зелинский приводит фразу каторжника из «Записок из мертвого дома Достоевского *Как т и л и с н у (ее) по горлу ножом и замечает: „Есть ли сходство между артикуляционным движением слова „тилиснуть“ и движением скользящего по человеческому телу и врезывающегося в него ножа? Нет, но зато это артикуляционное движение как нельзя лучше соответствует тому положению лицевых мускулов, которое инстинктивно вызывается особым чувством нервной боли, испытываемой нами при представлении о скользящем по коже (а не вонзаемом в тело) ноже: губы судорожно вытягиваются, горло щемит, зубы стиснуты - только и есть возможность произнести гласный $u$ и языковые согласные $m$, $\pi, c$, причем в выборе их, а не громких $\partial, p, 3$, сказался и некоторый звукоподражательный элемент 53 .

53 См.: Зелинский, 1911, с. 185-186. Ср.: Шкловский, 1919a, с. 16-17 (примеч.); Панов, 1967, с. 162 (примеч. 2).

Вообще о психофизиологической обусловленности значений различных звуков см., в частности, статьи Г.Н.Ивановой-Лукьяновой, Е.В.Орловой, М.В.Панова в сб.: Высотский, 1966; Штерн, 1967; Сепир, 1929; Ньюман, 
Для нас важно в этом примере то, что это слово произносит каторжник. Таким образом, человек, приносящий боль, произнеся данное слово, как бы сам испытывает чувство боли, - т.е., оставаясь самим собой, он как бы принимает одновременно и точку зрения своей жертвы, - в этот момент он сочетает в себе ощущения и Agens'a и Patiens'a действия (и деятеля и воспринимающего действие). Соответственно, можно сказать, что в одном слове здесь слиты точки зрения воображаемых участников действия - Agens'a и Patiens'a.

Подобное совмещение точек зрения в одном и том же элементе речи нередко проявляется в мимике, в интонации. Укажем, например, на ситуацию, когда мы задаем вопрос, причем заранее уверены в положительном на него ответе: очень часто здесь вопросительная интонация сочетается с утвердительной мимикой (кивком головы). Точно так же человек, рассказывающий, как он избил своего противника, одновременно с рассказом о своих ударах может имитировать искаженное от боли лицо своего противника (аналогичное явление характерно и для пантомимы); человек, который видит, как поодаль пробирается кошка, может произнести фразу: "кошка как тихо бежит" также тихим осторожным шепотом, - как бы с ее (кошкиной) точки зрения, т.е. органически сливая свою точку зрения с точкой зрения того, о ком он говорит.

Если искать аналогии в плане изобразительного искусства, можно сослаться на прием, особенно характерный для японского рисунка, когда художник как бы дает почувствовать зрителю самый жест автора, выражая, например, быстроту и гибкость движения птицы, которая изображается на рисунке, в быстроте и нервности самого штриха ${ }^{54}$. Иными словами, художник заставляет зрителя сделаться соучастником его творческого акта и в то же время объединяет в рисунке свои чувства и характеристики, присущие самому изображаемому им объекту.

1933; Бонфанте, 1964, с. 35 . О специальном использовании әтих значений в поэзии см.: Панов, 1966; ср. также замечания Г.А.Гуковского (Гуковский, 1965 , c. 61).

54 См. по этому поводу: Никитин, 1924, с. 214. Анвлогии сказанному нетрудно подыскать и на материале европейского искусства (где однако, әто явление имеет более индивидуальный характер) - сославшись, например, на вихревой мазок в живописи Ван-Гога, передающий иногда движение изображаемой формы, или на сплошкую линию, передающую движение, в графике Пикассо или Матисса. 


\section{Влиявие aвторского слова на чузхое слово}

Oтноснтелно мевее sоние случак. Bнyтрепнал речь

Все рассмотренные выше случаи объединяются тем общим свойством, что авторский текст в них тем или иным образом видоизменяется под влиявием чужого слова - или, иваче говоря, а в т о р ски й текст у подобляется чу жому слову.

Может быть, однако, и противоположный случай, который нам и предстоит рассмотреть, - а именно когда ч у ж о е с л о в о (в частности, речь персонажа) у подобля е т я а в т о р с к м у. Иначе говоря, в этом случае чужое слово испытывает на себе воздействие авторского слова и изменяется под его влиянием.

В достаточно явном виде эта авторская обработка чужого слова представлена в том случае, когда передакотся чувства и мысли героя, причем угадывается характерный для әтого героя текст, но при этом речь о герое ведется в третьем лице.

Вот, например, как описывает Толстой Петю Ростова, который идет в Кремль смотреть на Александра I:

Петя уже не думал о подаче прошения. Уже только ему увидать бы EIо [т.е. государя. бы себя счастливым! («Война и мир», т. XI, с. 89).

Здесь явно передается речь самого Пети, хотя формально она и преподносится от лица автора (ср., например, синтаксис последней фразы и особенно орфографическое выделение местоимения третьего лица, относящегося к Александру I, подчеркивающее идентификацию автора и героя) $)^{55}$.

Если мы заменим в приведенвом отрывке личное местоимение третьего лица (относящееся к герою) на местоимение первого лица, то мы получаем обычный случай монологической прямой речи ${ }^{56}$.

Таким образом, операция замены местоимений в данном случае функционально аналогична операции расстановки кавычек в

55 Ср. также разбор отрывка из «авказского пленника» в кн.: Волошинов, 1929 , с. 164.

${ }^{56}$ См.: Волошинов, 1929, с. 164; ср.: Томашевский, 1959, с. 288. 
приведенных выше случаях несобственно-прямой речи: обе операции приводят к одному результату, в итоге которого мы получаем из непрямой речи прямую.

Так образуется та разновидность повествования, которую при-

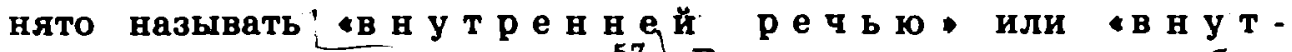
рен ни монологом57. Во многих случаях подобные примеры с равным правом могут рассматриваться и как результат воздействия авторского слова на слово героя и как результат обратного воздействия (т.е. как случай изменения авторской речи под влиянием чужого слова). Но иногда одной замены местоимений недостаточно для того, чтобы получить из речи автора речь персонажа, поскольку само слово персонажа может быть в достаточной степени обработано автором, окрашено авторской интонацией; в этом случае точка зрения автора и точка зрения персонажа неразрывно сливаются в тексте, в результате чего мы, воспринимая переживания героя с его точки зрения, все время слышим вместе с тем и интонацию самого автора ${ }^{58}$.

Вообще внутренний монолог героя (который формально может быть дан даже от первого лица) очень часто несет следы большего влияния авторской обработки, чем обычная (т.е. диалогическая) прямая речь того же героя: индивидуальность персонажа, проявляюцаяся в его диалогической прямой речи, часто устраняется автором во внутреннем монологе и заменяется собственно авторскими словами, автор выступает здесь как бы в качестве редактора, который обрабатывает текст данного персонажа.

Эта разница между способами оформления диалогической речи и внутреннего монолога может быть понята, по-видимому, только в том смысле, что если прямая речь персонажа представляет собой о б ъ е к т в н ы й факт и автор может стввить себя в положение человека, которому остается только со всей возможной точностью зафиксировать услышанное, то внутренний монолог отражает мысли и раздумья героя, и автор, соответственно, должен сосредоточиться на их сущности, а не на их форме.

Подобные случаи обработанной автором прямой речи вообще очень часто используются - как в литературе, так и в бытовом

67 Мы не останавливаемся специально на случаях диялогизации внутренней речи, когда единый внутренний монолог разбивается на два голоса. См. примеры из Толстого: Виноградов, 1939, с. 186.

58 См. подробнее: Волошинов, 1929, с. 156-157 (разбор отрывка из ‘Медного всадника•). 
рассказе - для передачи того, что должно было происходить в сознянии описываемого персонажа; в таких случаях нередко происходит ссылка как бы на условный внутренний монолог, ксторого нет на самом деле, но который в принципе мог бы быть представлен.

Примером может служить описание с точки зрения княжны Мары, которое переходит - в той же фразеl - в описание с точки зрения маленького князя Николая Болконского, а затем снова переходит в описание с точки зрения княжны:

Сколько раз она ни говорила себе, что не надо позволять себе горячиться уча п ле м я н и к раз, как она садилась с указкой за французскую азбуку, ей так хотелось поскорее, полечче перелить из себя свое знание в ребенка, уже боявшегося, что вот-вот т е т я рассердится, что она при малейшем невнимании со стороны м а ль ч и к а вздрагивала, торопилась, горячилась, возвышала голос, иногда дергала его за руку и ставила в угол (*Война и мир*, т. X, с. 301).

Мы имеем здесь совершенно очевидную ссылку сначала на точку зрения княжны, потом - на точку зрения маленького князя, наконец, вслед за этим - на абстрактную точку зрения автора-рассказчика: такие случаи представляют собой ссылку не столько на какие-либо особенности фразеологии соответствующего персонажа, сколько на его сознание. Тем не менее удобно отнести эти случаи именно к плану фразеологии, поскольку их можно представить как результат некоего предполагаемого внутреннего монолога (произведенного от лица персонажа), который затем переведен в план авторской речи.

Boree mane cryqux:

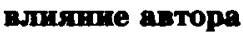

на прsinyo pers

действующих лищ

Еще более сильное влияние авторского слова на слово персонажа имеет место в том случае, когда автор говорит з а с в о го рероя. Это явление В.Н.Волошинов определяет как з а м е е н н у пря м у ю речь. В качестве иллюстрации 
данного явления Волошинов приводит следующий характерный отрывок из пушкинското ККавказского пленника 59.

Склонясь на копья, казаки

глядят на темный бег реки -

и мимо их, во мгле чернея,

плывет оружие злодея...

O чем ты думаешь, казак?

Воспоминаешь прежни битвы

Простите, вольвые станицы,

и дом о т о В, и ти хо मи Дов,

в о й а и к р с вы е де в и цы!

К брегам причалил тайный враг,

стрела выходит из колчана -

Взвилась - и падает казак

с окровавленного кургана.

(Пушкин, т. IV, с. 101; многоточие

в начале - Пушкина)

Разбирая этот отрывок, Волошинов пишет, что здесь чавтор предстательствует своему герою, говорит за него то, что он мог бы или должен был бы сказать, что приличествует данному положению. Пушкин за казака прощается с его родиной (чего сам казак, естественно, сделать не может) ${ }^{60}$.

Уже из последнего примера видно, что авторская обработка чужого слова может происходить не только в собственно авторском тексте, но и в прямой речи дей ст в ущи х лиц.

Так, в ↔Китии протопопа Аввакума», которое, как это показывает В.В:Виноградов ${ }^{61}$, в большой степени строится на параллелизме с библейскими мотивами, нередко происходит незаметное внедрение библейских текстов в речи действующих лиц ${ }^{62}$. Цитатами из Библии говорит не только сам Аввакум (что могло бы быть объяснено его духовным образованием), но и другие действующие лица. Так, в уста врага Аввакума, казачьего атамана Пашкова, Аввакум вкладывает слова Иуды (“Согрешил окаянный, пролил

59 См.: Волошинов, 1929, с. 163. Добавим еще, что тут имеет место характерны диалог автора с героем, от имени которого выступает тот же автор.

60 Taм же.

61 См.: Виноградов, 1923, с. 211-214.

62 Taм же, с. 213. 
кровь неповинну , Матф. XXVII, 4); в уста раскаявшегося Евфимея Стефановича и келаря Никодима - слова блудного сына и т.п. ${ }^{63}$. Таким образом, автор (Аввакум), по существу, говорит здесь за своих героев - но уже не в контексте авторского повествования (как в предыдущем примере), а непосредственно в прямой речи действующих лид ${ }^{64}$.

В других случаях әта авторская обработка прямой речи действующих лиц проявляется менее явно, хотя и может быть достаточно определенна; изменение степени авторского воздействия на чужое слово (в данном случае на прямуго речь действугщих лиц) при әтом с очевидностью свидетельствует об определенной смене авторской позиции (т.е. смене точек зрения при повествовании). Для иллюстрации этого мы обратимся к анализу авторской позиции при передаче прямой речи действующих лиц в «Вйне и мире - и прежде всего к рассмотрению случаев употребления французского языка (в прямой речи).

Некоторае вотросы astopcksol передпчr Iрям0 ретा

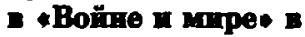
свзизі с проблемогі точек

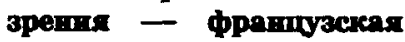

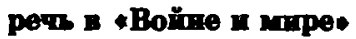
1 картамость Дентсола

Мы говорили выше о возможности ввторской обработки прямой речи действующих лиц, и в этой связи интересно рассмотреть

63 Тах же. - Отсюда едва ли выдерживают критику попытки некоторых авторов решить вопрос 06 историчности тех или иных новозаветных персонажей на том основании, что их речи восходят к ветхозаветным образцам (см. пример такой неудачной попытки в кн.: Ленцман, 1967, с. 44-45).

64 Это нерасчлененное слияние евангельских событий с событиями собственной жизни вообще характерно для Аввакума. Замечательно в әтой связи, что не только происходящее с вим описьвается Аввакумом через параллели с евангельскими сюжетами, но и, наоборот, евангельские события в его изложении могут испытывать определенное влияние его биографии. Так, пересказывая апокрифичөское Никодимово евангелие в своей -Беседе о кресте к неподобным , Аввакум повествует о том, как Христа волочили первосвященники Анна и Каиафа; упоминания об әтом нет в Никодимовом евангелии, зато атот факт точно соответствует биографии самого Аввакума, причем Анна и Каиафа неоднократно ассоциируются Аввакумом с патриархом Никоном (ск.: Демкова, 1965, с. 214, ср. с. 224). 
некоторые проблемы передачи прямой речи в Войне и мире . В результате такого рассмотрения оказывается, что Толстой в разных случаях как бы стоит на разных позициях по отношению $к$ передаваемой им прямой речи (которая может относиться при этом к одному и тому же лицу).

В одних случаях позиция автора ВВйны и мира - это позиция объекти вного наблюдателя, который слышит, что говорят другие (т.е. действующие лица), и задача которого состоит в том, чтобы со всей возможной точностью, как бы протокольно зафиксировать им услышанное. Отсюда педантизм и скрупулезность Толстого в передаче фонетических особенностей речи действующих лиц и вообще в н м а и е а в тор а к п р о и н ош е н и, ср. прежде всего картавость Денисова, а также различные неправильности в русской речи моряка на собрании в Слободском дворце (т. XI, с. 93), далее, речь полковника-гусара на именинном обеде у Ростовых и многочисленные другие примеры $^{65}$; тем же объясняется и дословная передача французской речи персонажей в •Войне и мире•.

Но это лишь одна из возможных авторских позиций: в другом случае позиция автора по отношению $K$ речи действующих лиц принципиально иная. Ее, скорее, можно было бы сравнить с позицией р е д а т о р a, пропускающего через свой фильтр все, что он слышит, и соответственно определенным образом о 6 р а 6 а ты в а ю щ г г прямую речь персонажей66.

Так, рассмотрение случаев употребления фракцузского языка в прямой речи действующих лиц •Войны и мира показывает, что французская или русская речь персонажей вовсе не всегда обусловлена тем, на каком языке данное лицо де й с т в и те л ь н о (в представлении автора) говорит в соответствующий момент, - но может иметь и чисто функциональные задачи, непосредственно связанные с проблемой авторской точки зрения.

В самом деле, очень часто французская речь (т.е. речь, которая предполагается автором реально произнесенной по-французски) может даваться по-русски (в русском переводе или пересказе), тогда как в других случаях она передается непосредственно так, как она была произнесена. Эта авторская обработка прямой речи

65 Ск.: Виноградов, 1939, с. 202-204.

66 Заметим, что эти две позиции могут интерпретироваться как синхронная и диахронная. Мы остановимся специально на этой проблеме ниже (с. 90 и сл.). 
парадоксально сочетается в •Войне и мире со стремлением к предельно точной фиксации речи действующих лиц, обнаруживаемой Толстым в других случаях.

Действительно, франдузы в «Войне и мире॰ время от времени изъясняются по-руески или же на смешанном русско-французском языке, подобном тому, какой представлен в романе в речи русских дворян. Например, по-русски обращается Наполеон к раненому князю Андрею, к пленному денщику Лаврушке, по-русски же он говорит с генералом Балашевым и даже с французскими генералами. Характерно, что во многих случаях Наполеон начинает с французского языка, а потом переходит на русский или мешвет французские и русские слова.

Иногда возможны даже диалоги, в которых адъютант Наполеона говорит по-французски, а Наполеон ему отвечает по-русски или же наоборот:

- Sire, le Prince...* - начал адъютант.

- Просит подкрепления? - с гневным жестом проговорил Наполеон (т. XI, с. 243; многоточие Толстого).

Или:

- Наш огонь рядами вырывает их, а они стоят, - сказал адъютант.

- Ils en veulent encore!.." - сказал Наполеон охриплым голосом (т. XI, с. 259).

Вырванные из общего контекста, эти отрывки могли бы быть поняты только одним способом - а именно, что Наполеон и его адъютант говорили друг с другом на разных языках (как это делают билингвы ${ }^{67}$.

* Государь, гердог...

"* Им еще хочетсяl..

67 Парадоксальный пример подобного столкновения языков в дивлогической речи встречается в -Хожении за три моря Афанасия Никитина, где вообще довольно широко используется иноязычная речь (на том или ином восточном языке - арабском, персидском, татарском) как изобразительное средство. Диалог между Афанасием Никитиным и мусульманином Меликом дается здесь таким образом, что слова Мелика приведены по-русски, а слова Афанасия Никитина - по-татарски, причем без русского перевода: * Бесерменин же Мелик, тот мя много понуди в веру бесермантскую стати. Аз же ему рекох: „Господине! ты намаз кыларесень, мен да намаз киларьмен; ты бешь на- 
Точно так же - то по-французски, то по-русски - говорят и другие французы: виконт де Мортемар, с которым мы встречаемся на вечере у Анны Павловны Шерер, Мюрат (т. XI, с. 19), Даву (т. XI, с. 21) и т.п.

Аналогично и французская речь русских дворян может быть дана автором не по-французски, а по-русски, причем Толстой может специально подчеркивать, что н а с а мом де ле р а з говор ше л по-французски.

Например:

- Отчего, я часто думаю, - заговорила она [маленькая княгиня. ц у з ски ... (т. IX, с. 31).

И далее вся речь княгини дается по-русски.

- Вот, по крайней мере, мы вами теперь вполне воспользуемся, милый князь, - говорила маленькая княгиня, р а з у м е т с я п о ф р в ц у з ск и, князю Василью... (т. IX, с. 272).

...князь Долгоруков ... п о - ф р а н ц у з с к и обратился к князю Андрею.

- Ну, мой милый, какое мы выдержали сражение (т. IX, c. 306).

И далее вся речь Долгорукова идет по-русски.

Где вы - там разврат, зло, - сказал Пьер жене. Анатоль, пойдемте, мне надо поговорить с вами, - сказал он п о - ф р в в у з с к и (т. Х, с. 366).

И далее там же:

маз кыларьсиз, мен да 3 кыларемень; мень гарип, а сень иньчай“ [т.е. ты молишься, и я молюсь; ты пять раз молишься, а я 3 раза; я - чужеземец, а ты - здешний]. Он же ми рече: „Истину ты не бесерменин кажешися, а хрестьянства не знаешь“ (Афанасий Никитин, 1986, с. 26; ср.: Трубецкой, 1983, с. 160 , примеч. 29 ; Успенский, 1994, с. 266 и сл.). Здесь подчеркивается иноязычная речь Афанасия Никитина, тогда как для его собеседника татарская речь нормальна (не является иноязычной) и, следовательно, не заслуживает внимания читателя. Соответственно, речь самого Афанасия Никитина представлена, так сказать, в авторском остранении, тогда как речь Мелика дается обычным для чнтателя образом - по-русски. 
- Вы обещали графине Ростовой жениться на ней? хотели увезти ее?

- Мой милый, - отвечал Анатоль п о - ф р а н ц у 3 ски (как и шел весь разговор), я не считаю себя обязанным отвечать на допросы, делаемые в таком тоне.

- Я очень, очень благодарна вам, - сказала ему княжна [Марья. - Б.У.] п о ф р в д у з с к и (т. XI, c. 161).

В других же случаях, как мы әто хорошо знаем, французская речь тех же Пьера, Анатоля, княжны Марьи, маленькой княгини или князя Долгорукова передается в романе непосредственно пофрандузски.

Более того, передавая французскую речь при помопи русского языка, Толстой может даже обращать наше внимание на особенности произнесения тех или иных французских слов - при том, что нам они дақотся в русском переводе:

- Вы верите всему, что вам скажут. Вам сказали... Элен засмеялась, - что Долохов мой любовник, -

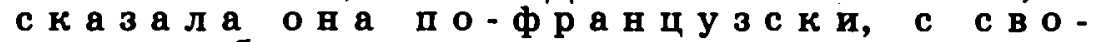
е г грубо то точностью речи, выго-

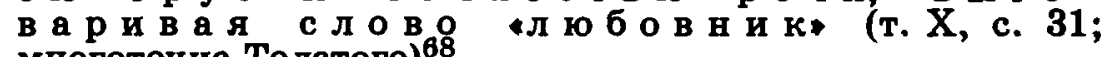
многоточие Толстого) ${ }^{68}$.

- Еще, может, д о т я н т с я до завтрашнего утра? спросил немец, д урно вы го в а р и в я по ф р в н у з ски (т. IX, с. 86).

Дурной французский язык доктора-немца здесь передается средствами русского языка (ср. неправильное употребление слова *дотянется $)^{69}$. Иначе говоря, с переводом французской фразы на русский язык неправильная французская речь переводится через неправильвый русский оборот (инвариантом остается прежде всего сама неправильность).

68 Характерно, что несколько ниже в той же сцене, передавая (по-русски) прямую речь Элен, где опять встречается слово «любовники», Толстой считает нужным сопроводить ато слово приведенным в скобках французским аквивалентом, как бы подчеркивая его реальное пронзнесенке: ...pедкая та жена, котррая с таким мужем, как вы, не взяла бы себе любовннков (des amants). (T. $\mathrm{X}$, c. 31 ).

69 Отмечено Виноградовым: Виноградов, 1939, с. 202. 
Ср. также разговор Наполеона с Лаврушкой:

Наполеон велел ему ехать рядом с собой и начал спрашивать:

- В ы к а з а к?

- Казак-с, ваше благородие (т. XI, с. 13).

Наполеон говорит как будто бы на том же самом языке, что и Лаврушка, но чрезвычайно показательно употребление им личного местоимения «выः: әто буквальный перевод с франдузского (русский офицер употребил бы в этой ситуации «ты») ${ }^{70}$.

Еще пример такого же рода:

- Вы негодяй и мерзавец, и не знаю, что́ меня воздерживает от удовольствия разможжить вам голову вот этим, - говорил Пьер, - в ы р а а я с ь т а к

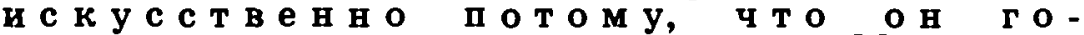
во р и л п - ф р нц у з ки (т. Х, с. 366).

Здесь, как и в предыдущем случае, французская речь персонажа передается русскими словами, но в то же время русский текст представляет собой неестественвый, буквальный перевод с фравцузского, сохраняя, таким образом, какие-то формальные характеристики исконного французского текста ${ }^{71}$.

Итак, реально произнесенная французская речь может передаваться в *Войне и мире то непосредствевно на франдузском языке, то в виде русской речи, то в виде смешанвого русско-французского разговора. Можно предположить, следовательно, что те случая, чрезвычайно распространенные в «Войне и мире», когда русские мешают французскую речь с русской, не обязательно обусловлены стремлением к доскональной передаче реальной речи в пред-

70 Соответствующая разница в обращении между французским и русским языками может быть прослежена и на реqи других персонажей «Войны и мира». Так, Наташа и Соня по-русски обращағотся друг к другу на чты», однако, переходя на французский язык, они употребляют местоимение мн. числа (vous).

71 Любопытно сопоставить әти примеры с төм неправнльным русским языком, на котором написано письмо Жюли Друбецкой к княжне Марье или на котором говорят русские дворяне в салоне Жюли, - в период Отечественно войны, когда говорить по-французски стало непатриотично. Во всех әтих случаях мы имеем буквальный перевод с французского, сохраняющий грамматические особенности французского оригинала. 
ставлении автора, в могут быть следствием каких-то специяльных (композиционных) задач.

Отсгда, между прочпм, следует, что в тех случаях, когда прямая речь в романе дается по-русски (или в виде смешанной русско-франпузской речи) - и не сопровождается специальной ремаркой автора относительно того, как произносклась данная фраза, - мы в принципе не молид знать, на каком языке она мыслилась пропзнесенной в действительности. Между тем там, где дается непосредственно французский текст, мы знаем, что данның текст был на деле пронзнесен по-французски. Можно сказать, что оппозидия французского и русского языков может нейтрализоваться в •Войне и мире॰, причем франщузский язык выступает как маркированный член оппозиции.

Весьма показательно в этой связи свидетельство самого Толстого, который писал (в заметке Несколько слов по поводу книги „Война и мир“): „Для чего в моем сочинении говорят не только русские, но и французы частью по-русски, частью по-французски? Упрек в том, что лица говорят и пишут по-французски в русской книге подобек тому упреку, который бы сделал человек, глядя на картину и заметив в ней черные пятна (тени), которых нет в действительности. Живописец не повинев в том, что некоторым тень, сделанная им на лице картины, представляется черным пятном, которого не бывает в действительности; но живописец повинен только в том, ежели тени эти положены неверно и грубо... И потому, не отрицая того, что положенные мной тени, вероятно, неверны и грубы, я желал бы только, чтобы те, которым покажется очень смешно, как Наполеон говорит то по-русски, то по-французски, знали бы, что это им кажется только оттого, что они, как человек, смотрящий на портрет, видят не лицо со светом и тенями, а черное пятно под носом : (т. XVI, с. 8-9).

Таким образом, французский язык нужен автору «Войны и мира. не столько для соотвесения с реальной действительностью (описываемой в произведении), сколько как те х н и че ски й п р и е м изображения ${ }^{72}$.

72 Упрекая Толстого в нелогичном использовании французского языка, некоторые критики писали, что для того, чтобы показать, что Наполеон или другое какое-либо лицо говорил по-французски, достаточно было бы ему [Толстому. - $B . Y$.$] первую его фразу написать по-французски, а остальные -$ по-русски ( (см.: Виноградов, 1939, с. 147). Очевидным образом подобного рода возражения не учитывают именно композиционной функции данного приема. 
Очевидно, что французский язык нужев Толстому прежде всего для того, чтобы передать индивидуальность стиля говорящего (наряду с другими средствами речевой характеристики - индивидуальными словами и т.п.), дать возможность читателю почувствовать, как тот говорит, т.е. дать ему (читателю) как бы ключ к манере разговора, характерной для того или иного говорящего. Далее же, после того как читатель составил себе впечатление об общей манере речи, автор может уже и не быть столь педантичным в передаче разговора.

Совершенно аналогичное замечание должно быть сделано в отнопении картавости Денисова. Картавость Денисова передавалась Толстым, хотя и непоследовательно, в первом и втором издании «Войны и мира*, но была упразднена автором в третьем (1873 года) - т.е. именно в том издании, в котором и французский язык заменен на русский. Едва ли это совпадение можно считать случайным: представляется, что картавость Денисова вообще функционально аналогична французской речи действующих лиц в • Войне и мире.. Именно поэтому передача картавости и непоследовательна - точно так же как непоследовательна и передача французской речи, как мы это только что имели возможность видеть. Так же как и в случае с французским языком, автору важно не столько досконально точно передать фонетические особенности каждой фразы Денисова, сколько дать читателю общее впечатление от его манеры выражения - и время от времени напоминать ему (т.е. читателю) об этой манере ${ }^{73}$.

Можно сослаться на аналогичный прием в Евангелии, где слова Христа в одних случаях передаются в переводе, в других же случаях даются прямо поарамейски - с приложением перевода (например: Марк, V, 41, XV, 34; и в других местах) или даже вообще без перевода (ср.: «вминь глаголю вам...., где :аминь» - арамейское слово, обозначающее «нстинно»).

73 В связи со сказанным представляется ошибочным подход к тексту -Войны и мира в кобилейном издании Толстого (редакторы текста «Войны н мира - Г.А.Волков и М.А.Цявловский), где французский язык сожранен (так же как в первом и втором изданиях, но вопреки третьему изданию), но картавость Денисова удразднена (так же как в третьем изданин, но вопреки первому и второму) (см. объяснительное примечавие редакторов в т. IX юбилейногс издания, с. 455). Этот подход кажется нам непоследовательным именно лотому, что картавость и французская речь аналогичны по своей функции. Ссылка на то, что Денисов картавит не везде (см. т. IX, с. 455), конечно, не чожет служить оправданием такого подхода, поскольку то же заме- 


\section{•Внутренняя и :внешняя* позиция автора \\ в плане фразеологии}

Итак, при передаче французского языка, картавости Денисова и вообще всевозможных неправильностей речи персонажей можно проследить две принципиально различные авторские позиции. Натуралистическое воспроизведение иностранной или неправильной речи специально подчеркивает дистанцию между позицией говорящего действующего лица й позицией описывающего его наблюдателя (с точки зрения которого в данный момент ведется- повествование); иначе говоря, специально подчеркивается несовпадение (разобщенность) этих позиций, а иногда даже и известная *странность позиции говорящего для описывающего.

Показательно в этом отношении сравнение способа передачи французской речи у Толстого и в прозе Пушкина. Б.В.Томапевский отмечает, что «Пушкин, который в личной жизни гораздо чаще [чем Толстой. - Б.У.] был принужден обращаться к французскому языку и в устной и в письменной форме, вовсе не стремится к воспроизведению иностранной речи действующих лищ 74 .

Помимо разницы стилистических приемов у обоих писателей это несомненно объясняется и тем, что во времена Пушкина употребление французского языка не было маркированным, т.е. было настолько повседневным явлением, что не было необходимости его специально отмечать, - тогда қак Толстой описывает ту же эпоху, что и Пушкин, но с д р у г х п о и ц и й: с позиций более позднего времени, когда употребление французского языка уже было в известной степени маркированным ${ }^{75}$.

Характерно, между тем, что в тех случаях, где это нужно автору, - например, при противопоставлении французской и русской речи действующих лиц - французские фразы передаются Пушкиным документально (примером может служить диалог Дефоржа-Дубровского и помещика Спицына в главе X •Дубровско-

чание в равной степени может быть отнесено и к французскому языку в - Войне и мире .

74 См.: Томашевский, 1959 a, с. 437.

75 С. характерный спор о французском языке в откликах прессы на •Войну и мир - спор, который, как известно, заставил Толстого в третьем и четвертом изданиях романа вообще убрать французский текст, заменив его русскими әквивалентами. 
гон, где первый говорит по-французски, а второй - по-русски); французская речь здесь очевидным образом маркирована.

Можно сказать, что в тех случаях, когда автор натуралистически воспроизводит иностранную или неправильную речь, он использует как бы впечатление со стороны (позицию стороннего наблюдателя), т.е. он прибегает к точке зрения заведомо в н е ш н е й по отношению к описываемому лицу. Действительно, писатель акцентирует здесь то, что брос а е т я в $г л$ а з $а$, - но бросается в глаза именно человеку постороннему, тогда как человек достаточно близкий или знакомый просто не замечает этих особенностей. Автор воспроизводит здесь в н ш н и е особенности.

Между тем, там, где писатель сосредоточивается не на внешних особенностях речи, а на ее существе, так сказать, не на ее "как», а на ее «что, переводя соответственно указанные специфические явления в план нейтральной фразеологии, - там фразеологическая точка зрения описывающего приближается к точке зрения описываемого (говорящего) персонажа. (Предельный случай подобного сосредоточения на существе, а не на форме имеет место при внутреннем монологе, где речь героя вообе смыкается с авторской речью; мы уже отмечали, что для внутреннего монолога характерно и отвлечение от специфики выражения.) Тем самым в противоположность описанной выше в н шн е й точке зрения, здесь можно говорить о точке зрения вн утренне й.

Понятно, что указанное сближение фразеологических позиций описывающего (автора или рассказчика) и описываемого (действующего лица) может быть констатировано с тем большим основанием, чем меньше различий в фразеологии того и другого. Полярные случаи здесь представлены, с одной стороны, воспроизведением специфических особенностей языка персонажа (случай максимального различия) и, с другой стороны, внутренним монологом (случай минимального различия).

Натуралистическое воспроизведение внешних особенностей речи нередко используется автором для того, чтобы дать читателю представление об общей манере речи, характерной для описываемого персонажа, - после чего автор может уже и не подчеркивать в дальнейшем особенностей его манеры говорить. Так, например, описывается немец-генерал в Оренбурге в «Капитанской дочке 76 . При его характеристике нам сообщается про его немецкий акцент,

${ }^{76}$ Отмечено Томашевским: Томашевский, $1959 a$, с. $439-440$. 
и действительно, мы слышим этот акцент (сказывающийся в оглушении согласных, особенно начальных) в его прямой речи: "Поже мой!“ - сказал он. - „Тавно ли, кажется, Андрей Петрович был еще твоих лет, а теперь вот уш какой у него молотецl $\mathrm{Ax}$, фремя, фремяl“... и далее (Пушкин, т. VIII, с. 292). Но затем передача акцента прекращается и речь генерала передается нормальвым русским языком. Мы как бы уже вошли в описываемое действие - воспринимая его теперь не со стороны, а изнутри - и перестали слышать акцент генерала. (Точно так же, например, нам бросается в глаза картавость незнакомого нам человека, но мы можем забыть о ней, когда становимся хорошо с ним знакомы.)

Таким образом, здесь дается сперва точка зрения в н е ш н я я по отношению к говорящему, т.е. как бы впечатление стороннего наблюдателя от разговора данного человека, которая затем может сменяться - время от времени или же раз и навсегда точкой зрения в н у ре н н ей: читатель как бы познакомился с манерой речи и может позволить себе отвлечься от внешних средств выражения, чтобы сосредоточиться на ее существе ${ }^{77}$.

До сих пор мы рассматривали случаи, когда при передаче прямой речи действующего лица проявляется либо "внешняя", либо «вутренняя позиция автора. Разумеетя, при этом возможны и переходы от одной позиции к другой на протяжении повествования.

Следует указать между тем, что позиции эти могут синтетически совмещаться в тексте, почти одновремевно проявляясь в речи описываемого персонажа, в результате чего точка зрения описывающего (автора) теряет какую бы то ни было определенность (раздваивается или даже становится ирреальной).

Иллюстрацией здесь нам будет опять служить французская речь в «ойне и мире». Характерно, например, что при передаче французской речи русскими средствами какие-то слова все-таки могут даваться непосредственно по-французски. Например, в речи Наполеона: "Правда ли, что Moscou называют Moscou la sainte? Сколько церквей в Moscou? (т. XI, с. 30). Здесь в одном слове (Моscou) происходит ссылка на сознание Наполеона: Москва для него Moscou, и в этом случае Толстой считает нужным указать на

77 Подробнее см. в разделе о ирамках художественного текста (глава седьмая). 
то, как это слово было реально произнесено, - при том, что все другие слова той же фразы перөданы им с другой позиции ${ }^{78}$.

Порождение фраз подобного рода можно представить как результат синтеза (нерасчленимого совмещения) реально произнесенной французской фразы и ее русского перевода. В других случаях реальная фраза и ее перевод объединяются в тексте, образуя не синтез, а соположение. Так, передавая речь французов в виде русской речи, Толстой иногда чувствует необходимость непосредственно в тексте д у $б$ и р о в а т русские слова их французскими эквивалентами.

Приведем примеры.

Из речи Наполеона:

- Поднять этого молодого человека, ce jeune homme, и снести на перевязочный пункт! (т. IX, с. 357).

- Et vous, jeune homme? Ну в вы, молодой человек? (т. IX, c. 358).

- ..даю вам честное слово... даю вам ma parole d'honneur (т. XI, c. 27).

Из речи Александра I:

- Какая ужасная вещь война, какая ужасная вещь! Quelle terrible chose que la guerrel (т. IX, c. 312).

Из речи масона графа Вилларского:

- Еще один вопрос, граф... на который я вас не как будуцего масона, но как честного человека (galant homme) прошу со всею искренностью отвечать мне (т. X, с. 73) ${ }^{79}$.

78 Получающийся в результате аффект внешне совершенно аналогичен тому, что обычно имеет место при двуязычии, когда в одной фразе совмещаются әлементы, принадлежащие двум разным языкам.

79 Мы можем теперь суммировать способы передачи французской прямой речи, которые использует автор ‘Войны и мира». Французская речь может передвваться:

а) непосредственно по-французски,

б) в русском переводе,

в) в виде смешанного двуязычного текста - когда одна часть фразы дается по-французски, а другая по-русски,

г) в виде дублирования одного и того же выражения и по-французски, и́ по-русски. 
Автор тем или иным способом объединяет здесь воедино реально произнесенную фразу и ее перевод. Толстой выступает тем самым как бы в качестве переводчика, который, давая перевод, считает нужным кое-где сослаться и на оригинальный текст; автор как бы помогает читателю, время от времени ориентируя его на р е а л в н е условия произнесения фразы.

Фразы, получающиеся в результате подобного совмещения авторских позиций, в реальной речи, разумеется, невозможны, да они и не претендуют на однозначную соотносимость с реальной действительностью. Смысл данного приема состоит вообще в ссылке на общие условия произнесения фразы или же на индивидуальное сознание говорящего.

Подобные же случаи перевода - для отсылки к тому или иному индивидуальному восприятию - возможны не только при передаче в •Войне и мире прямой речи, но и непосредственно в авторском тексте:

Увидев на той стороне казаков (les Cosaques) и расстилавшиеся степи (les Steppes), в середине которых была Moscou la ville sainte, столица того, подобного Скифскому, государства, куда ходил Александр Македонский, - Наполеон неожиданно для всех... приказал наступление... (т. XI, c. 8).

Здесь происходит очевидная ссылка на индивидуальное сознание Наполеона в виде французских слов, вкрапленных в русский текст (последние, таким образом, представляют собой элементы чужого слова, внутренней речи в авторском тексте), - причем там, где автор употребляет русское слово (*степи), он тут же дает и его французский перевод (4les Steppes»), как бы ссылаясь на восприятие самого Наполеона ${ }^{80}$.

Итак, мы имеем здесь случай п р е в д а авторского текста на индивидуальный язык персонажа.

Возможны и обратные случаи, когда автор переводит с языка индивидуального (использующего элемевты чужого слова) на язык объективного описания.

Решили, что Илье Андреевичу ехать нельзя, а что ежели Луиза Ивановна (m-me Schoss) поедет... (т. X, с. 281).

80 Вообще о функции скобок в авторской репи у Толстого см.: Виноградов, 1939 , c. 179 . 
Государь в преображенском мундире, в белых лосинах и высоких ботфортах, со звездой, которую не знал Ростов (это была légion d'honneur)... (т. X, с. 146).

В обоих случаях индивидуальное восприятие переводится в план авторской речи.

Особенно показательно в этой связи описание охоты в Отрадном, которое дается как бы одновременно с двух точек зрения: со специальной охотничьей (в н у т р н н ей по отношению к описываемому действию - использующей позицию самих участников охоты) и обычной, нейтральной (в н е ш н ей по отношению $к$ описываемому действию - использующей позицию постороннего наблюдения). Описание охоты производится на специальном охотничьем языке - но охотничьи выражения каждый раз п е р е в о д я т я на нейтральный язык - в точности так же, как французские выражения могут переводиться в •Войне и мире на русский язык:

Русак уже до половины за те р я (пе ре ли н я л) (T. X, c. 244).

...борзая собака ... стремительно бросилась к крыльцу и, подняв п $\mathrm{p}$ а в и́ $л$ о ( $\mathrm{X}$ в о с т), стала тереться $\circ$ ноги Николая (т. Х, с. 245).

Волк ... прыгнул раз, другой и, мотнув п о л е н о м (х в о с т о м), скрылся в опушку... вся стая понеслась по полю, по тому самому месту, где п р о л е 3 (п р о 6 е ж а л) волк (т. X, с. 251).

Он знал, что в острове были п р и бы лы е (м о л ды е) и м а т ры е (с т а р ы е) волки (т. Х, с. 252).

...волк покосился на Карая, еще дальше спрятав п о л е н (х в о с т) между ног и наддал скоку (т. $\mathrm{X}$, c. 254).

...вот кругами стала вилять лисица между ними, все чаще и чаще делая эти круги и обводя вокруг себя пушистою т р у бо й (Х во с то м) (т. X, с. 256). 
... [Николай. - Б.У.] сказал, что он дает рубль тому, кто по до́ з рит, то есть н а йд т ле жа ч е го з а й а а (т. X, с. 259 ).

Охотничьи выражения здесь очень близки по своей функции французским словам: и там и здесь имеет место чередование авторских позиций, которое сводится к чередованию *внутренней и «внешней. точек зрения. 


\section{3 „Точки зрения“ в плане прострапственно-временно́й характеристики}

В определевных случаях точка зрения повествователя может быть как-то - с болышей или меньшей определенностью - фиксирована в пространстве или во времени, т.е. мы можем догадываться о м с т е (определяемом в пространственных или временни́х координатах), с которого ведется повествование. В чаством случае, как мы увидим далее, это место рассказчика может совпадать с местом определенного персонажа в произведении, т.е. автор в этом случае как бы ведет репортаж с места нахождения данного персонажа.

В несколько иных терминах здесь можно было бы говорить о пространственной или временно́й п е р с п е т и в е при построении повествования, причем аналогия с перспективным построением здесь представляет собой нечто большее, нежели простую метафору.

Перспектива в широком смысле может пониматься вообще как система передачи изображаемого трех- или четырехмерного пространства в условиях художественных приемов соответствующего вида искусства; при этом в случае классической (линейной) перспективы в качестве точки отсчета выступает позиция лица, непосредственно производящего описание. В изобразительном искусстве речь идет о передаче реального многомерного пространства на двумерной плоскости картины, причем ключевым ориентиром является позиция художника; в искусстве словесном это может быть, соответственно, словесная фиксация пространственно-временны́х отношений описываемого события к описывающему субъекту (aвтору).

Мы рассмотрим сначала примеры фиксации авторской точки зрения в трехмервом пространстве, а затем перейдем к примерам фиксации ее во времени. 


\section{Пространство}

\section{Совпадение пространственних позиций повествователя и персонаха}

Мы уже говорили, что позиция повествователя (или наблюдателя) может совпадать либо не совпадать с позицией какого-то определенного действующего лица в произведении. Обратимся сначала к первому из әтих случаев. Действительно, нередко мы можем констатировать, что рассказчик находится там же, т.е. в той же точке пространства, где находится определенный персонаж, - он как бы «рикрепляется к нему (на время или на всем протяжении повествования). Например, если данный персонаж входит в комнату - описывается комната, если он выходит из дома на улицу - описывается улица и т.д. При этом в одних случаях автор целиком п е ре в о п ш ш е т с в это лицо, т.е. "принимает» на данный момент его идеологию, фразеологию, психологию и т.д.; соответственно и точка зрения, принимаемая автором при описании, проявляется тогда во всех соответствующих планах.

Но в иных случаях автор с л д у е т за персонажем, но не перевоплощается в него; в частности, авторское описание может быть не субъективно, а надличностно. В этом случае авторская позиция совпадает с позицией данного персонажа в плане пространственной характеристики, но расходится с ней в плане идеологии, фразеалогии и т.П. Поскольку автор не перевоплощается в данного персонажа, а как бы становится его спутником - он может давать и описание этого персонажа (что, естественно, невозможно было бы сделать, пользуясь целиком системой восприятия последнего) ${ }^{1}$.

Сдучаи такого пространственного прикрепления автора к своему герою очень распространены. Так, например, в значительной части повествования в -Бесах Достоевского автор (рассказчик) следует за Ставрогиным, хотя описывает происходящие события не с его - или, лучше сказать, не только с его - точки зрения ${ }^{2}$. B «Братьях Карамазовых повествователь на большие периоды ста-

1 В определенных случаях подобное описание можно определить как описание, полученное совмещением нескольких точек зрения - например, психологической точки зрения данного героя плюс самого рассказчика, незримо сопутствующего герою. См. подробнее ниже (главу пятую).

2 Иллюстрацию и анализ см. ниже (в главе пятой). 
новится незримым спутником Алеши, Мити и т.Д. Нередко подобное следование автора за свонм героем становится п о в о д м для того, чтобы описать то или иное событие (не обязательно с точки зрения данкого героя). Так, следуя за Пьером (в «Войне и мире»), мы попадаем на Бородинское сражение и становимся его свидетелями (причем Пьер как бы только п р и в о д и т нас на Бородино, а затем, попав на поле боя, мы уже не обязательно с ним связаны: мы можем оторваться от него и выбрать иную пространственнуюо позидию).

Иногда место повествователя может быть определено лишь относительно: он может быть прикреплен не к одному какому-то персонажу, а к некоторой компании людей, но мы можем констатировать присутствие его в каком-то определенном месте. Ср., например, описание одного из вечеров у Ростовых в «Войне и мире». Молодежь (Наташа, Соня и Николай) сидит в диванной и вспоминает о детстве, причем описание не ведется с чьей-либо конкретной точки зрения.

- Эдуард Карлыч, сыграйте пожалуйста мой любимый Nocturne мосье Фильда, $\bar{x}$ с а 3 а л го л о с старой графини из гостиной (т. $X$, с. 278).

В ответ на просьбу графини Диммлер играет на арфе.

- Наташаl теперь твой черед. Спой мне что-нибудь, послы ш л с я г лос графини (т. X, с. 279).

Толстой мог бы просто сообщить нам, что графиня п р о и 3 н е с л а данные фразы из гостиной; если бы он так написал, то не было бы пространственной определенности позиции рассказчика, какая имеет место в приведенном случае. При этом подобная фраза была бы совершенно возможна и вполне вписывалась бы в данный текст: так, недосредственно ниже Толстой пишет, что * граф Илья Андреевич из кабинета, где он беседовал с Митинькой, слышал ее [Наташи. - Б.У.] пенье (т. X, с. 280), - и в этом случае автор переходит от пространственно определенной (конкретной) $к$ пространственно неопределенной позиции, при которой ему дано знать и видеть не только то, что делается в одной комнате, но и то, что делается во всем доме или в других местах.

С другой стороны, автор мог бы сказать, что Наташа, Соня или Николай у с лы ш а и голос графини, т.е. сослаться на их восприятие; это был бы случай «психологической точки зрения, 
использование которой, вообще говоря, очень обычно для Толстого $^{3}$. Характерно, однако, что в дапном случае автор этого не делает; выбранная им позиция - это позиция человека, незримо присутствующего в комнате и описевағщего то, что он видит.

\section{Oтсутствие совпадения пространствепой познции автора с познцией персонаха}

Мы рассматривали случаи, когда точка зрения, с которой производится повествование, совпадает с пространственной позицией того или иного действующего лица (или группы лиц). В других случаях подобного совпадения нет - при том, что и здесь может иметь место пространственная определенность позиции повествователя.

Мы остановимся на нескольких формах такого повествования.

Последовательный 0630p

Иногда точка зрения повествователя последовательно скользит от одного персонажа к другому, от одной детали к другой - и уже самому читателю предоставляется возможность с м о н и р о в а т эти отдельные описания в одну общую картину. Движение ввторской точки зрения в этом случае аналогично движению объектива камеры в киноповествовании, совершающей последовательный обзор какой-то сцены.

Именно так описывается сражение у Гоголя в «Тарасе Бульбе: : автор последовательно выхватывает своим объективом то одно, то другое единоборство из общей массы сражающихся; при этом авторский объектив не произволен в своем движении - он описывает подвиги одного персонажа до тех пор, пока того не убьют, затем переходит к его победителю и остается с ним до тех пор, пока и тот, в свою очередь не стяновится побежденным, - и т.д. и т.п. Авторская точка зрения как трофей переходит от побежденного к победителю.

3 О психологидеской тодке зрения редь идти будет ниже (см. главу четвертую). 
Авторское описание в данном случае отнюдь не безлично: автор постоянно находится рядом с каким-то участником битвы, все время переходя от одного $к$ другому (причем самый переход от персонажа к персонажу становится возможным только в случае их непосредственного контакта: авторский объектив не самостоятелен в своем перемещении по полю боя, его можно сравнить, скорее, с эстафетой, которая последовательно передается от одного к другому). Таким образом,' в известном смысле здесь еще сохранена пространственная прикрепленность повествователя к"персонажу, обусловленность авторской позиции позицией действующего лица.

В других случаях движение авторской точки зрения никак не обусловлено перемещением действующего лица, т.е. авторская точка зрения совершенно независима и самостоятельна в своем движении. Ср., например, подобный прием в описании званого обеда у Ростовых в «Во̆не и мире»:

Г р а ф из-за хрусталя, бутылок и ваз с фруктами поглядывал на жену и ее высокий чепец с голубыми лентами и усердно подливал вина своим соседям, не забывая и себя. Гр а ф и н я так же, из-за ананасов, не забывая обязанности хозяйки, кидала значительные взгляды на мужа, которого лысина и лицо, казалось ей, своею краснотою резче отличались от седых волос. На д а м с ко м ко н ц е шло равномерное лепетанье; на м у с к о к о ц е все громче и громче слышались голоса, особенно гусарского полковника, который так много ел и пил, все более и более краснея, что граф уже ставил его в пример другим гостям. Б е р $\Gamma$ с нежною улыбкой говорил с Верой о том, что любовь есть чувство не земное, а небесное. Б о р и с называл новому своему приятелю Пьеру бывших за столом гостей и переглядывался с Наташей, сидевшею против него. $\Pi$ ь е p мало говорил, оглядывал новые лица и много ел. ...Н а т а ш а, сидевшая против него, глядела на Бориса, как глядят девочки тринадцати лет на мальчика, с которым они в первый раз только что поцеловались и в которого они влюблены... Н и к ол а й сидел далеко от Сони, подле Жюли Карагиной, и опять с тою же невольною улыбкой что-то говорил с ней. С о н я улыбалась парадно, но, видимо, мучилась ревностью: то бледнела, то краснела и всеми силами прислушивалась к тому, что́ говорили между собою Николай и Жюли. Г у в е р н а н т а беспокойно оглядывалась, как бы приготавливаясь к отпору, ежели бы кто вздумал обидеть 
детей. Г у в е р н е $\mathrm{p}$ - н е м е ц старался запомнить все роды кушаний, десертов и вин с тем, чтобы описать все подробно в письме к домашним в Германию, и весьма обижался тем, что дворецкий с завернутою в салфетку бутылкою обносил его (т. IX, с. 75-76).

Авторский объектив здесь как бы переходит от одного из сидящих за столом к другому, последовательно обегая всех присутствующих за столом; эти отдельные сцены складываются в одну общую картину; аналогичный прием очень обычен в кино.

Подобный охват сразу почти всех действующих лиц, со скольжением от персонажа к персонажу, тем более разителен, что он сменяет более обычную для Толстого прикрепленность в каждой фиксированной фазе описания к одному или немногим действующим лицам (отсюда становится понятным возникающий при столь быстрой смене авторской позиции, какая имеет место при «последовательном обзоре , зффект сгущения времени).

Последовательный обзор сидящих за столом как бы имитирует движение взгляда человека, осматривающего эту картину. Это движение, однако, не принадлежит никому из действующих лиц, но только самому автору, который как бы незримо присутствует на месте действия.

Такой же пример используется Толстым и при описании ужина у князя Василия на именинах Элен (перед помолвкой Элен и Пьера) (т. IX, с. 257). В этих случаях пространственная позиция автора относительно реальна - в том смысле, что он как бы находится среди тех действующих лиц, которых он описывает.

В других случаях позиция автора при последовательном обзоре действующих лиц не характеризуется подобной пространственной определенностью: автор может совершать обзор людей, которые находятся в разных местах, не обозримых с одной точки зрения. Так, например, после приезда Анатоля Курагина в Лысые Горы для сватовства к княжне Марье, когда все разошлись по своим комнатам, Толстой дает последовательный обзор действующих лиц (он описывает по.порядку, что делают Анатоль, княжна Марья, m-le Bourienne, маленькая княгиня, старый князь, см. т. IX, c. $278-279)^{4}$ - совершенно аналогичный приведенному выше, с той только разницей, что описываемые лица здесь не объединяются единым (реально обозримым) местом действия.

4 Аналогичный прием см.: т. X, с. 280. 
Пространственное перемещение авторской позиции здесь очевидно: автор как бы обходит одну за другой комнаты дома, заглядывая поочередно к каждому персонажу.

Типологические аналогии как с приемом скольжения кинокамеры, так и с киномонтажом не требуют особых комментариев.

Другіе случах मnuments nomung паблодателя

Мы только что говорили о случаях, когда описание ведется с переменвой позиции; иначе говоря, описывающий наблюдатель перемещается в пространстве - движется по полю описания. При этом в вышеприведенных Примерах описание распадается на ряд отдельных сцен, каждая из которых дается со своей пространственной позиции; совокупность этих сцен, собственно говоря, и передает движение - подобно тому, как передает движение совокупность кадров кинопленки, каждый из которых в отдельности неподвижен.

Но перемещение позиции описывающего наблюдателя может передаваться и совершенно другим способом - не в виде отдельных последовательно фиксированных сцен, которые в сумме своей воссоздают движение, но в виде одной сцены, схваченной с движущейся позиции (с характерными деформациями предметов, обусловленными этим движением).

Если проводить параллели из области визуальной коммуникации (рисунок, фотография и т.п.), то мы знаем, что движение некоторой фигуры может быть передано либо как совокупность различных сцен, где данная фигура представлена в различных позах (тогда зрителю предлагается мысленно суммировать эти позы воедино, представив себе движущуюся фигуру), либо как о д н а сцена с определенным искажением формы, вызвавным самим процессом движения. Если мы фотографируем, например, движущийся объект и нам необходимо передать движение, мы можем или снять его несколько раз с достаточно короткой экспозицией (в этом случае мы получим несколько последовательных кадров, совокупность которых и позволит воссоздать движение объекта), либо мы можем употребить более длительную экспозицию - и тогда движение объекта будет передано определенной деформацией его изобра- 
жения (смазанностью и т.п.). Эти два различных принципа передачи движения прослеживаются и в изобразительном искусстве ${ }^{5}$.

Указанные приемы передачи движевия могут быть отмечены в литературе (нас интересует здесь движение точки зревия повествователя). Первый прием был проиллюстрировав выше примерами -последовательного обзора.. Для того чтобы проиллюстрировать второй прием, мы сошлемся ва исследование художественного простравства у Гоголя, произведенвое Ю.М.Лотманом ${ }^{6}$. Здесь показывается, что в целом ряде случаев в описании у Гоголя можно констатировать движущуюся точку эрения.

Обратимся к примерам:

Серые стога сена и золотые снопы хлеба станом располагаются в поле и к о ч у 10 т по его неизмеримости (т. I, c. 111$)^{7}$.

Точно так же могут вести себя у Гоголя деревья, горы (см., напримep, т. I, c. 271).

Тени от дерев и кустов, к а к к о м е ты, острыми клинами падали на отлогую равнину (т. II, с. 186).

Разбирая этот последний пример, Лотман замечает, что если образ чтень как острый клин со всей определенностью указывает на то, что описание ведется с точки зрения наблюдателя, смотрящего сверху, то в образе -тень как комета свойственный комете

5 О применении указаниых приемов в изобразительном искусстве и о некоторых возможностях семиотической их трактовки см. с. 221 и сл. наст. изд. Можно сказать, что в первом случае имеет место а н а л и ти ч е ск а я трактовка движения: непрерывный продесс движения аналитически разлагается на ряд дискретных компонентов, синтезировать которые предоставляется уже зрителю (читателю). В то же время во втором случае имеет место с и н т е т и ч е с к и й охват впечатлений, полученных с разных (пространственных) точек зрения; этот синтез производится непосредственно в самом описании (изображении).

6 См.: Лотман, 1968; следующие далее примеры берем из әтой работы. См. также: Белый, 1934, с. 126-127.

7 С. аналогичное описание у Гоголя в том случае, когда использование движущейся точки зрения мотивировано в тексте: Чудно снова показалось кузнецу, когда он понесся в огромной карете, качаясь на рессорах, когда с обеих сторон мимо его бежали назад четырехатажные домы, и мостовая, гремя, казалось, сама катилась под ноги лошадям * («ооь перед Рождеством * T. I, c.n234). 
изгиб обусловлен искажением изображения под влиянием скорости передвижения смотрящего наблюдателя ${ }^{8}$.

Иллюстрацией может служить также стихотворение Пастернака «Косых картин... (из цикла *Я их мог позабыть*):

Косых картин, летящих ливмя

C mocce...

Перемещение показано здесь с точки зрения движущегося объекта - машины, летящей по шоссе: движение машины показано через движение летящих ей навстречу образов. Одновременно в сознании возникает картина косого ливня (ассоциацию с которым вызывяет слово *ливмя*).

Разумеется, случаи подобного использования движущейся позиции наблюдателя совсем не часты, и поэтому затруднительно было бы привести много примеров такого рода. Но существенно подчеркнуть саму возможность такого построения описания.

\section{O6mas \\ (всеохвативaromag) \\ точке зрения: \\ точке зрентя \\ -mтmque nojeta*}

При необходимости всеобъемлющего описания некоторой сцены нередко имеет место не последовательный ее обзор и вообще не использование движущейся позиции наблюдателя, а одновременный охват ее с какой-то одной общей точки зрения; такая пространственная позиция предполагает обычно достаточно широкий кругозор, и потому ее можно условно называть точкой зрения «птичьего полета*.

Понятно, что подобный широкий охват всей сцены предполагает вынесение точки зрения наблюдателя высоко вверх. См. пример поднятой позиции у Гоголя в *Тарасе Бульбе:

И козаки, прилегши несколько к коням, пропали в траве. Уже и черных шапок нельзя было видеть; одна только быстрая молния сжимаемой травы показывала бег их (T. II, c. 58).

${ }^{8}$ См.: Лотман, 1968 , с. 36. 
Характерно, что наблюдатель занимает при повествовании достаточно о п р е де л е н у ю позицию, т.е. его позиция не абстрактна, а совершенно реальна (в этой связи показательно упоминание о том, чего не мог видеть наблюдатель с занятой им позиции) ${ }^{9}$.

Очень часто точка зрения *птичьего полета используется в начале или в конце описания некоторой сдены (или же всего повествования). Например, при описании некоторой сцены с большим количеством действующих лиц нередко дается сперва общий взгляд на всю сцену сразу, т.е. общее, суммарное описание данной сцены, произведенное как бы с птичьего полета, а затем уже автор переходит к описанию действующих лиц, т.е. может принимать более дробные (мелкие) зрительные позиции; точно так же этот прием может быть применен и в конде некоторого описания. Таким образом, точка зрения «птиьего полета может окаймлять все произведение в целом; об этой функции данной точки зрения нам еще придется говорить в связи с проблемой «рамок художественного произведения.

В качестве примера можно привести концовку Тараса Бульбы 10. Тарас погибает мученической смертью, и далее дается описание Днестра, произведенное явно с какой-то безличной точки зрения, характеризующейся очень широким кругозором:

Немалая река Днестр, и много на ней заводьев, речных густых камышей, отмелей и глубокодонных мест; блестит речное зеркало, оглашенное звонким ячаньем лебедей, и гордый гоголь быстро несется по нем, и много куликов, краснозобых курухтанов и всяких иных птиц в тростниках и на прибрежьях. Козаки живо плыли на узких двухрульных лодках, дружно гребли веслами, осторожно минали отмели, всполапивая подымавшихся птиц, и говорили про своего атамана (т. II, с. 172).

9 Замечательно, что там, где Гоголь по условиям сожета и принятой композиционной установки не может поднять наблюдателя ввысь (такая ситуация создается, в частности, в том случае, когда автор ведет повествование с какой-то конкретной пространственной позиции - скажем, с позиции определенного персонажа), - он *искривляет самую поверхность земли, загибая ее края (не только горы, но и мореl) вверх^. См.: Лотман, 1968, с. 20, 15; цитируется *Срашная месть (Гоголь, т. I, с. 275). Там же см. о том, какуго роль играет вид сверху в *Вин*, *Тарасе Бульбе», «Метвых душах .

$10 \mathrm{Cp}$. также описание войск перед Аустерлицким сражением в Войне и миренф(т. IX, с. 330). 


\section{Немая сцена}

Особый случай обобщенного описания с некоторой достаточңо удаленной позиции представляет собой так называемая ннемая сценан, характерная, в частности, для Толстого ${ }^{11}$, т.е. тот случай, когда поведение действующих лиц описывается как пантомима: описываются их жесты, но не даются их слова.

Примером может служить описание начала смотра под Браунау в «Войне и мире :

Сзади Кутузова ... шло человек 20 свиты. Господа свиты разговаривали между собой и иногда смеялись. Ближе всех за главнокомандующим шел красивый адъютант. Это был князь Болконский. Рядом с ним шел его товарищ Несвицкий, высокий штаб-офицер... Несвицкий едва удерживался от смеха, возбуждаемого черноватым гусарским офицером, шедшим подле него. Гусарский офицер, не улыбаясь, не изменяя выражения остановившихся глаз, с серъезным лицом смотрел на спину полкового командира и передразнивал каждое его движение. Каждый раз, когда полковой комиссар вздрагивал и нагибался вперед, точно так же... вздрагивал и нагибался вперед гусарский офицер. Несвицкий смеялся и толкал других... (т. IX, с. 142-143).

4Немая сцена указывает на удаленность позиции наблюдателя (до него как бы не доходят - в силу его удаленности - голоса описываемых лиц, но он может их наблюдать). Эта удаленная позиция дает возможность достаточно обобщенного показа.

\section{Время}

Подобно тому, как в тексте часто может быть фиксирована позиция повествователя в трехмерном пространстве, в целом ряде случаев может быть определена и его позиция во в ре м е н и 12 . При этом самый отсчет времени (хронология событий) может вестись автором с позиций ка ого-либо персонажа или же со своих собственных позиций.

11 О ннемой сцене см.: Сабуров, 1959, с. 430.

12 Вообще о времени в литературе (под разными углами зрения) см., В частности: Выготский, 1968; Лихачев, 1967, ч. IV («Поэтика художественного времени ); Мейергоф, 1960; Пуйон, 1946. 
В первом случае авторское время (которое кладется в основу повествования) совпадает с субъективным отсчетом событий у того или иного из действующих лиц.

Например, в Пиковой даме А.С.Пушкина, как показал В.В.Виноградов ${ }^{13}$, счет времени ведется сначіала с позиций Лизаветы Ивановны (которая при этом ведет отсчет со дня получения письма Германна). Ее переживанием времени повествователь пользуется вплоть до изложения смерти старухи. Далее, когда повествование идет о Германне, повествователь принимает и точку зрения Германна, проявляющуюся во временно́м плане, т.е. его отсчет времени (а отсчет времени Германна производится с того дня, как он услышал анекдот о трех картах).

Таким образом, повествователь может менять свои позиции, последовательно становясь на точку зрения то одного, то другого персонажа; в то же время повествователь может использовать и свою собственную временную позицию. В этом случае при повествовании используется собственно авторское время, которое не совпадает с индивидуальным временем какого-либо действующего лица.

Различные возможности сочетания авторской позиции с позицией персонажей в произведении определяют возможные способы усложнения композиционной структуры. Нас вообще будут интересовать здесь - так же как и в предыдущих разделах - различные случаи м ножественности точек, зрения, т.е. множественности временны́х позиций в произведении.

\section{Множественность временни́́х позпций \\ в произведении. \\ Совмещенная точка зрения}

Множественность временных позиций может проявляться в произведении разными способами - иначе говоря, различные временни́е позиции могут по-разному сочетаться друг с другом.

С одной стороны, повествователь может п о с е д о в т е л н о менять свою позицию - т.е. описывать события то с

${ }^{13}$ См.: Виноградов, 1936, с. $114-115$. 
одной, то с другой точки зрения (ими могут быть как точки зрения различных действующих лиц в произведении, так и собственная позиция повествователя). Этот случай был только что проиллюстрирован на примере пушкинской ‘Пиковой дамы .

При этом в одних случаях события, описываемые с разных временны́х позиций, могут перекрываться (т.е. одни и те же события даются на протяжении повествования в освещении нескольких различных точек зрения), тогда как в других случаях повествователь их организует впритык (т.е. повествование ведется в строго последовательном порядке, причем на разных этапах изложения используются точки зрения разных действующих лиц). И тот и другой вид повествования в общем достаточно элементарны по своей композиционной структуре.

С другой стороны, описание одного и того же эпизода может вестись о д н о в р е м в н о с нескольких позиций - представляя собой в этом случае результат не соположения, а с и н т е 3 а разных точек зрения, слияния их воедино. Описание тогда производится как бы с двойной экспозицией. Формально это совмещение точек зрения может проявляться, например, в ремарках, в сопутствующих комментариях или же в замечаниях, которые предварякт описание данного эпизода, служа как бы тем фоном, на котором воспринимается последующее изложение.

Например, повествование может вестись одновременно во временно́й перспективе некоторого персонажа (или же нескольких персонажей, учвствующих в действии) и вместе с тем в перспективе самого автора, точка зрения которого существенно отличается во временно́м плане от точки зрения данного персонажа: автор знает то, чего не может еще знать этот персонаж, а именно - знает, «чем кончится д данная история. Иначе говоря, тут имеет место двойная перспектива, двойная позиция повествователя. В первом

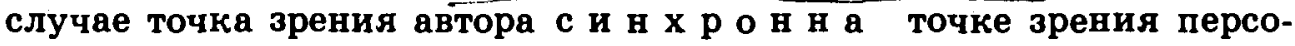
нажа, автор становится на точку зрения его н а с т ящ е го, между тем во втором случае авторская точка зрения р е т р ос п е к т в н а, автор как бы смотрит из его б у д у щего. fначе можно сказать, что в первом случае точка зрения автора - и соответствующего персонажа - в н у р е в я я по отношению К повествованию, автор как бы смотрит извутри оп̆еываемой жизни (принимая при этом присущие данному персонажу ограничения в знании того, что будет дальше); во втором же случае авторская точка зрения, напротив, Вне шн я я по отношению К_самому 
повествованию, автор как бы смотрит со стороны на описываемые события (причем, естественно, он знвет при этом то, чего не дано знать описываемым действующим лицам).

Другими словами, мы имеем в виду те случаи, когда автор, оставаясь на позициях того или иного персонажа (т.е. продолжая вести описание с его точки зрения), как бы забегает впе p е д, вдруг открывая нам то, чего персонаж - носитель авторской точки зрения - знать никак не может (но о чем он должен узнать позже, по прошествии некоторого времени). Иллюстрации здесь могут быть достаточно многочисленны 14 - поэтому те, которые мы приведем, по необходимости имеют случайный характер.

Так, в значительной части романа Достоевского —Братья Карамазовы в центре внимания автора и читателя находится Дмитрий Карамазов, который и выступает при этом как носитель авторской точки зрения - что проявляется в самых разных планах (см., например, восьмую книгу романа). В частности, автор (точнее, рассказчик, от лица которого повествует автор, но разница эта сейчас для нас не существенна) подробно описывает его восприятие (принимая, таким образом, его психологическую точку зрения ${ }^{15}$ ); иногда автор пользуется в повествовании и его фразеологией (переходя на внутренний монолог - см., например, т. XIV, с. 337), т.е. принимает его точку зрения и в плане фразеологии; точно так же автор принимает и его пространственную точку зрения (следуя за ним во всех его перемещениях); наконец, и последовательность событий дается автором в общем и целом так, как их воспринимает Митя, т.е. именно с его точки зрения. Но в то же время в отдельных эпизодах автор как бы забегает вперед, сообщая нам (читателю), че м к о н и т с я дандый эпизод - чего сам Митя, естественно, знать уже никак не может. Примером здесь может служить, в частности, эпизод с поездкой к Лягавому для продажи отцовской рощи, где нам с самого начала объявляется, что затея эта оковчится неудачей. В результате наша позиция как бы рассеивается: с одной стороны, мы продолжаем находиться с Митей и пользоваться его восприятием - мы находимся в его н а с т о я е м; но, с другой стороны, мы воспринимаем происходящее несколько иначе, чем он, поскольку мы смотрим и из его 6 у ду щего

14 Можно напомнить в этой связи о многих произведениях, начинающихся с констатации смерти героя, о котором пойдет речь, т.е. начинающихся с конца (ср., например, у Толстого «Хаджи Мурат», “Смерть Ивана Ильича»).

150 психологической точке зрения см. главу четвертую настоящей работы. 
(пользуясь при этом уже не точкой зрения Мити, а специальной точкой зрения рассказчика).

Таким образом, совмещение различных временных планов получается за счет совмепения, во-первых, точки зрения о пи сы в аеме-о лица (в данном случае персонажа) и, во-вторых, точки зрения о п и сы в а ю щ е $r$ о лица (автора-рассказчика). Подобного рода явление вообще очень распространено как в художественной литературе, так и в повседневном рассказе.

Существенно указать при этом, что совмещение разных временни́х планов может в принципе происходить и тогда, когда описывающий и описываемый субъект совпадагот в одном и том же лице - в случае Icherzählung (повествования от первого ліица). Это очень обычно, в частности, в автобиографиях: совмещается точка зрения в описываемый момент и в момент описания.

Здесь можно сослаться, например, на +Житие протопопа Аввакума». С одной стороны, изложение событий ведется у Аввакума достаточно последовательно, причем, как отмечает Д.С.Лихачев, восприятие времени у Аввакума прежде всего субъективно и показывает * большей мере последовательность событий, чем их объективную временну́ю прикрепленность 16. С другой же стороны, как указывает тот же исследователь, изложение событий у Аввакума связано и с тем временем, в которое пишется житие: напоминания об этом времени встречаются регулярно. ^Аввакум, - говорит Д.С.Лихачев, - как бы смотрит на свое житие из определенной точки настоящего, и эта точка зрения крайне важна в его повествовании. Она определяет то, что можно было бы назвать временной перспективой, делает его произведение не просто повествованием о своей жизни, а повествованием, осмысляющим его положение в тот момент, когда он писал его....17.

Таким образом, если в примере с Митей Карамазовым мы устремлялись из его настоящего в его будуще е, то здесь мы смотрим - вместе с Аввакумом - и з н а с т о я е го в п р о шा ло $\mathrm{e}^{18}$.

В то же время о ц е н и в а т свое настоящее, как и свое прошлое, Аввакум с точки зрения будущего- с точки зрения

16 См.: Лихачев, 1967 , с. $303-304$, где сказанное иллюстрируется конкретным разбором текста.

17 Taм же, с. 305.

18 О совмещении точек зрения в более общем плане мы будем говорить ниже. 
будущей (загробной) жизни ${ }^{19}$. Таким образом, временна́я перспектива может проявляться не только в плане непосредственных композиционных задач описания, но и, независимо, в плане идеологической оценки - подобно тому как приемы фразеологии могут служить самостоятельным композиционным задачам или же быть вспомогательным средством для выражения идеологической точки зрения (см. об этом выше ${ }^{20}$ ). При этом данные точки зрения не обязательно совпадают в произведении. В плане идеологической оценки могут быть разные возможности проявления временно́й перспективы: в одном случае факты настоящего и прошлого могут оцениваться с точки зревия будущего, в другом случае факты настоящего и будущего оцевиваются с точки зрения прошлого, наконец, в третьем случае - все оценивается с позиции настоящего 21 .

\section{Грамматическая форма}

временг и вида

п времевка́я позиция автора

Во многих случаях средством выражения временно́й позиции повествования выступает форма грамматического времени. Таким образом, видо-временны́е формы глагола имеют недосредственвое отношение не только к ливгвистике, но и к поэтике; как мы увидим позже, в области поэтики данные грамматические формы могут даже приобретать специальное значение.

Обратимся к примерам. Мы возьмем для иллюстрации «Леди Макбет Мценского уезда Н.С.Лескова. Надо сказать вообще, что это произведение крайне показательно с точки зревия используемых в нем глагольных форм, поскольку прошедшее повествовательное постоянно чередуется здесь с настоящим (описательным). Ср., например, начало шестой главы:

Катерина Львовна з а к р ыл а окно ... да и ле г л а. ...С п и т и н е с п и т Катерина Львовна, а только так ее и ом а р и а ет, так лицо потом и о $б$ ли в а е тся, и ды ши тся ей... Ч у в ст у е т Катерина Львовна... Наконец кухарка п о д о ш л а и в дверь по т уч л а: Самовар - говорит.

19 См.: Лихачев, 1967, с. 309.

${ }^{20}$ С. $27-28$ наст. изд.

21 Ср. в әгой связи: Пятигорский и Успенский, 1967, с. 24-27. 
...Катерина Львовна... насилу п р о к и н у л а с ь... А кот ... т р е т с я ... Катерина Львовна з а в о р о ІІ и л а с ь ... а он ... $\pi$ е з е т (т. I, с. 106).

Здесь почти в каждой фразе имеет место изменение формы времени по сравнению с тем, что было в предыдущей: если в предыдущей фразе было прошедшее время, то в следующей фразе употреблено настоящее время, и наоборот.

В другом отрывке из того же произведения чередование формы настоящего и прошедшего времени также имеет место, но в более крупных масштабах: изменение формы времени происходит не со сменой фраз, а со сменой целых кусков повествования:

П р о с у л с я Сергей, у с п к о и л... и $\ldots$ з а с н у л. ...Л е ж и она с открытыми глазами и вдруг с лы ш и т... Вот собаки ме т н л и с ь было, да и с т и х л и.

Далее несколько абзацев в прошедшем времени; затем опять настоящее:

Катерина Львовна тем временем с л ыш и т... но не жалость, а злой смех $\mathrm{p}$ а з 6 и р а е т Катерину Львовну. «Ищи вчерашнего дня" - д у м а т она... Это І ро д о л ж л о с ь минут десять...

И далее довольно большой отрывок, где все глаголы следуют в прошедшем времени: описывается - с последовательным употреблением формы прошедшего времени, - как Катерина Львовна впускает своего мужа Зиновия Борисыча, как она с ним разговаривает, как она бегает проведать своего любовника Сергея, спрятанного на галерее.

Затем описание неожиданно опять переходит в настоящее время.

А Сергею... все слышно... Он с л ы ш и т...-

идет описание того, что слышит Сергей.

- Что ты там возилась долго? - с п р а ш и в а е т... Зиновий Борисыч.

- Самовар ставила, - о т в е ч а т она...

И далее на некотором протяжении подряд идут глаголы настоящего времени, которые затем сменяются прошедшим (см. т. I, c. 114-115). Примеры эти легко можно было бы продолжить и дальше. 
Очевидно, что настоящее время знаменует здесь фиксацию точки зрения, с которой производится описание: можно сказать, что каждый раз, когда употребляется глагольная форма настояще-

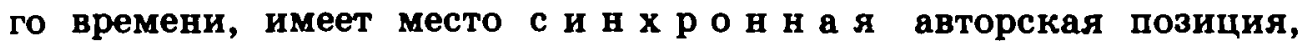
т.е. автор находится как бы в том же времени, что и описываемый персонаж. Между тем глаголы в прошедшем времени отмечают переходы к каждому новому описанию с синхронной позиции, т.е. $к$ каждой последующей фиксации точки зрения ${ }^{22}$. Можно сказать, что глаголы прошедшего времени как бы описывают те условия, которые задаются для того, чтобы можно было воспринимать описание с синхронной позиции.

Иначе говоря, все повествование в этом случае как бы распадается на ряд сцен, каждая из которых дана с синхронной точки зревия. Внутри әтих сцев время как бы останавливается ${ }^{23}$. Между тем глаголы прошедшего времени описывают те изменения, которые имеют место в каждой новой сцене (и, следовательно, задают контекст, в котором она должна восприниматься).

Построение повествования здесь можно сравнить с демонстрацией диапозитивов, связанных какой-то сюжетной линией: при показе каждого диапозитива время останавливается, тогда как в промежутках между демонстрациями оно чрезвычайно конденсировано (течет очень быстро ${ }^{24}$ ). Иначе говоря, непрерывный временно́й поток представлен здесь в виде дискретных квантов, время между которымй очень сгущено.

Подобное же привлечение грамматического настоящего времени при повествовании весьма характерно и для бытового (повседневного) рассказа. Ср. характерный оборот (в рассказе, где речь идет о прошлом и превалируют соответственно формы прошедшего времени): «а тут он мне и говорит.... Очень часто настоящее время используется в рассказе в кульминационный момент (типа:

22 Соответственно грамматическое настоящее время как формальный прием фиксации времени можно сопоставить со специальными формами, передающими фиксацию зрительного взора в древней живописи - такими, как округлости, блики ( оотметкин) и т.П. (см. с. 268-269 наст. изд.).

23 При несколько ином подходе можно было бы считать, что әти сцены характеризуются своим особым микровременем.

24 Ср. в әтой связи наблюдение Д.С.Лихасева относительно былин: ^Те әпизоды в былине, где действие совершается быстро, переданы в грамматиqеском прошедшем времени, а те, где оно замедлено, - в настоящем • (Лихачев, 1967, с. 241). 
«вошел я - и вижу...»). Этот прием явно имеет целью вовлечь слушателя внутрь самого действия рассказа, поставить его на то м е с т о, на котором находится герой рассказа.

Чередование грамматических времен нередко встречвется в одной и той же фразе, где они показывакт внезапную смену точек зрения. Например, у протопопа Аввакума:

Он меня л а е т, а я ему рек л: «багодать в устнех твоих, Иван Родионович, да будет» 25 .

Противопоставление глагольных форм позволяет передать соотношение действий в реальном времени: здесь противопоставляются не только формы грамматического прошедшего и настоящего времени, но и совершенного и несовершенного вида; в результате попучается, противопоставление одиночного действия («рекл») действию длительному («лает»). Подобное столкновение времен во фразе характерно для поэзии Хлебникова:

С к а к а л а весело княжна, 3 в е н я т жемчужные стрекозы

или:

И П ь е т задумчив русский квас

Он за молч а л тих кури л ...26

Следует заметить, что форма настоящего времени - не единственная грамматическая форма, позволяющая фиксировать момент и передать синхронность позиции повествователя ${ }^{27}$.| В определенных условиях в аналогичной функции может выступать форма несовершенного вида прошедшего времени.

25 «ЖКнге протопопа Аввакума*, см.: Аввакум, 1927, стлб. 11.

26 Другие примеры см.: Марков, 1962, с. 100.

27 Укажем, в частности, на возможность близкого по функции использования формы будуцего времени, ср. у Андрея Белого в ППервом свидании :

Михаил Сергеич повер н т т я,

Ко мне из кресла цвета єбискр•;

Стекло пенснайное п роснет я,

П ере п т ес н т с блеском искр.

(Белый, 1966, с. 416-417). 
Ярче и полнее всего это проявляется в фольклоре. Например:

Владимер князь стал пьянешинек и веселешинек

В ы х о д и на середка кирпищат пол

С ноги на ногу п е р е с т у п ы в а л

Из речей сам выго в а р и в $а$ л.

В с т а в а л Потык на резвы ноги,

В ы х о д и л на середка кирпищат пол

И всем челом би $л$, низко к л а н я л с я

П р и 6 е г а л и жаребьцы да к коню доброму...

и т.п. ${ }^{28}$.

Характерно, что в фольклорных произведениях в этой же функции - едва ли не в тех же ситуациях - может употребляться и форма настоящего времени. Например:

И оттуль-де Иван скоро поворот д а е т,

Он в ы х о д и т -де скоро вон на юлицу,

Он п $\mathrm{p}$ и $\mathrm{x}$ о д и т -де скоро к коню доброму,

Он как с к а ч е т -де скоро на добра коня.

Опеть с к а ч е т его да ноньце доброй конь

Он-де с гор-де ноньце с к а ц е т ноньце на гору.

Он с укатистой-то с к а ц т на увалисту,

Ыщә горы-удолы промеж ног б е р е т

По поднебесью л е т и т он как ясен сокол,

$\Pi$ р и е ж ж т -де ко городу ко Киеву,

А е ж ж а е т он тут до ко божьей черкви,

Он соскакивал тут скоро со добра коня...29

Условно говоря, по своему композиционному значению форма несовершенного вида прошедшего времени знаменует как бы ннастояцее в прошлом . Точно так же как и форма настоящего времени в приведенных выше примерах, данная форма позволяет производить описание как бы изнутри самого действия - т.е. с синхронной, а не ретроспективной позиции, - помешия читателя непосредственно в центр описываемой сцены,

28 Ончуков, 1904, с. 237-238, 109.

29 Оичуков, 1904, с. 105-106. В приведенном отрывке любопытно, между прочим, внимание описывающего к обозначению времени (ср. многократные повторения слов “скоро и чноньце при описании). Ср. наблюдения А.Ф.Гильфердинга о вставных словах типа «ныне , ‘было , “есть в русских былинах (см.: Гильфердинг, I, с. 37). 
Точнее можно сказать, что здесь имеет место синтез ретроспективвой и синхронной точек зрения. Данная форма показывает, что все действие, в общем, совершается в проплом, но в әтом проплом рассказчик занимает синхроннуг позицию. Таким образом, можно считать, что в этом случае имеет место совмещение двух типов рассказчика, соответствующих двум различным точкам зрения: общй рассказчик (функциовиругщий во всем повествовании в целом), по отношению к которому действие относится к прошлому, и чвстны рассказчик (функциониругой специально в данной конкретной сцене), по отвошенпо к которому действие пропсходит в настоящем.

Совмещение этих двух точек эрения и дает то значение, которое выражается в данном случае формой несовершенного вида прошедшего времени - значение ннастоящего в прошедшем*. 0 сложной (совмещенной) точке зрения мы будем подробнее говорить ниже (в главе пятой).

В нефольклорной литературе подобное использование формы несовершенного вида прошедшего времени встречается только в одной достаточно узкой области - а именно в выраженияХ, вводящих прямую речь, и прежде всего в так называемых verba dicendi ${ }^{30}$. Например, у Лескова в «Леди Макбет Мценского уезда»:

- Чего это вы так радуетесь? - спросила Катерина Львовна свекровых приказчиков.

- А вот, матушка Катерина Ильвовна, свинью живую вешали, - о т в е ч а л ей старый приказчик.

- Какую свинью?

- А вот свинью Аксинью... - смело и весело р а с с к а 3 ы в а л молодец...

- Черти, дьяволы гладкие, - р у г а л а с ь кухарка.

- Восемь пудов до обеда тянет... - опять о 6 ъ я с н я $\pi$ красивый молодец... (т. I, с. 99).

И далее в том же духе.

Подобное употребление несовершенного вида (в глаголах говорения) никак нельзя отнести за счет арханческого стиля; оно живо и сейчас, будучи вполне практикуемо и в современной литературе.

Между тем с точки зрения разговорного русского языка в каждом из только что приведенных случаев правильнее было бы употребить форму совершенного вида, т.е. мы бы с к а 3 а л и, соответственно (если бы речь шла именно об устном рассказе, а не о письменной речи) не чобъяснял молодець, а «объяс-

30 Verba dicendi букв. - глаголы говорения. 
3 „Тотки арения“ в плане прострапственво-врекеняо́й характеристики 101

нил молодец , не «отвечал приказчик», но єответил приказчик и Т. П.

Форма несовершенного вида возможна только при связном повествовании и в специальных условиях письменной (литературной) речи, - в ином контексте она кажется странной и неоправданной. В самом деле, логически несовершенный вид тут может быть даже и непонятен: непонятно, например, почему употреблена форма о т в е ч $\pi$, когда приказчик уже о т в е т л. В повседневной речи подобная форма была бы воспринята, скорее всего, как передакщая многократность действия либо его чрезмерную длительность; но ни то, ни другое значение не имеется в виду в письменной речи. Дело идет, таким образом, именно об у с л о в о й системе, принятой при повествовании.

Итак, в данном значении/форма несовершенного вида прошедшего времени свойственна именно письменному языку/, где она выступает как специальная повествовательная форма. Тем самым ее правомерно сравнивать со специяльными повествовательными глагольными формами, которые существугт в целом ряде языков (типа французского passé simple).

Каково же специальное поэтическое значение формы несовершенного вида?/Форма несовершенного вида противопоставлена форме совершенного вида прежде всего в плане позиции наблюдателя по отношеник к данному действию/(действию говорения)/ Она создает эффект продолженного времени $\leftarrow$ мы как бы помещаемся внутри данного действня, становясь по отношению к нему синхронными свидетелями (выше мы видели, что такое же значение может иметь и форма настоящего времени) ${ }^{31}$. Иначе говоря, противопоставление видовых форм выступает в плане поэтики как противопоставление синхронной и ретроспективной позиции автора ${ }^{32}$.

31 Другими словами, здесь передается примерно то же значение, которое в апглийском языке регулярно выражается формой continuous - т.е. протяженность действия по отношению к воспринимающему его наблюдателю. Последний, таким образом, оказывается в центре самого действия, воспринимая его нзнутри.

32 Следует отметить, что несовершенный вид verba dicendi нередко фигурирует именно в ответах, т.е. достаточно характерным вообще представляется примерно следующая модель чередования глагольных форм, вводящих прямую речь:

«...., - с п р о с и (или: ск а з а л) $\mathbf{N}$.

«...., - о т в е ч а л ему NN.

(ср. такое противопоставление и в цитированном отрывке из Лескова). Это и 


\section{Степень определенности \\ (конкретности) пространственно- \\ временно́ĭ тотки зрения. \\ План пространственно-временно́й \\ характернстики \\ в различнка видах пскусства}

Рассмотрение проблемы точки зрения в пространственно-временно́м аспекте тесно связвно с рассмотрением вообще специфики художественного пространства в том или ином анализируемом произведении. Действительно, можно думать, что пространственновременны́ характеристики изображаемого мира не обязательно совпадают в разных произведениях. Речь идет здесь не столько об относительности самого изображаемого пространства и времени ${ }^{33}$, сколько о с т п п н и к о н к е т н с т и пространственновременно́го изображения мира.

Следует отметить, что мера конкретности моделирования пространственно-временни́х характеристик в литературном произведении определяется прежде всего спецификой литературы как вида искусства. При этом необходимо иметь в виду, что! и ме н н о в пл а не прост ранственно-в ременно́ й х а рактеристики могутбыть найдены наи большие аналогии между литературой и д угими ( иепрезентативными) ви дами и с к у с с т а: если все другие планы, в которых может проявляться точка зрения, являются в большей или меньшей степени присущими именно словесному творчеству, то проблема прострвнства и времени объединяет словесное и изобразительное искусства.'

В то же время специфические условия организации художественного текста в разных видах искусства определяют бо́льшую или

понятно: вопрос обычно вводит нас в микроповествование (сцену), входя в которое мы оказываемся как бы в продолженном времени.

Ср. известное двустишие Козьмы Пруткова:

- Вы любите ли сыр? - с п р о с и л и раз ханжу.

一 Люблю, 一 он о т в е а л, 一 я вкус в нем нахожу.

(Прутков, 1933, с. 73).

33 См. об этом, в частности: Лотман, 1968; Богораз (Тан), 1923; Богораз, 1925. В последних двух работах рассматривается специфика пространственного моделирования мира в мифологических представлениях. 
меньшую релевантность тех или иных характеристик пространственно-временно́го континуума и, соответственно, предполагают бо́льшую или меньшую определенность в их передаче.

Если изобразительное искусство по своему существу предполагает достаточно большую конкретность в передаче собственно п р о т р а н т в е н ы х характеристик изображаемого ми$\mathrm{pa}^{34}$, но в то же время допускает полную неопределенность в отнопшении характеристик в р м ен и, - то/литература, напротив, связана в первую очередь не с пространством, а с временем: пронзведение литературы, как правило, довольно конкретно в отношении времени, но может допускать полную неопределенность ири передаче пространства. Последнее свойство заложено уже в естественном языке, т.е. в самом материале литературы: специфику языка в ряду семиотических систем определяет то кардинальное обстоятельство, что языковое выражение п е р в о д и т пространство во время. В самом деле, словесное описание любого пространственного соотношения, вообще любой реальной картины, которая предстает нашему взору, по необходимости передается в виде последовательности, протяженной во времени.

Вместе с тем, указанная разница обусловлена специальными условиями восприятия художественного текста в обоих указанных случаях: в случае изобразительного искусства восприятие происходит прежде всего в пространстве и необязательно во времени, тогда как в случве художественной литературы восприятие пронсходит прежде всего во временно́й последовательности (между тем театр или кино, по-видимому, предполагакот более или менее одинаковую степень конкретности в обоих этих планах ${ }^{35}$ ).

34 Заметим в то же время, что степень этой конкретности и здесь может варьироваться в известных пределах. См.: Успенский, 1970, с. 32 -33.

35 Укажем, что степень близости литературного и драматического произведения неодинакова в рассматтриваемом аспекте в разных случаях, и ато сказывается прежде всего на трактовке времени. В старом театре мы нередко наблюдаем точно такое же разложение одновременных действий в последовательность, какое по необходимости должно иметь место в литературе. В этом отношении характерно выключение актеров из времени: скажем, Чацкий проиэносит монолог, а Молчалин, стоящий рядом, на это время как бы выключен из действия и т.П. (әто особенно явно в тех случаях, когда первый актер произносит соответствующий монолог «про себя и второй не может даже пантомимически участвовать в действии, реагируя на его слова).

Аналогичное явление - разложение одновременных действий в последовательность - можно наблюдать, между прочим, и в кино в связи с монтажным прие- 
Укажем, в частности, что|восприятие литературного произведения непосредственно связано с п а м я т ь ю/(свойства человеческой памяти вообще налагают ряд ограничений на литературное произведение - ограничений, необходимых именно для восприятия последнего), тогда как восприятие произведения изобразительного искусства не предполагает с необходимостью использование памяти. Между тем непосредственная связь памяти и времени достаточно очевидна ${ }^{36}$.

Характерно, с другой стороны, что если в произведении изобразительного искусства и выражено время - например, в виде определенной последовательности сцен, где участвуют одни и те же фигуры $^{37}$, положим, последовательности слева направо, - то и в этом случае имеет место принципиально бо́льшая (нежели в других видах искусства) с в о бо д а в вы бо ре в ре м е н и: в самом деле, мы можем читать картину, скажем, слева направо, имея в этом случае прямой порядок времени или же, напротив, справа налево - и тогда имеем обратный порядок времени/(что можно сравнить с фильмом, запущенным в обратном порядке - от конца к началу ${ }^{38}$ ), наконец, мы можем выбирать в качестве точки отсчета любую сцену на картине и двигаться от нее в произвольном направлении - и тогда имеем совершенно иной порядок вре-

мом: дается крупным планом лицо человека, произносящего остроту, а затем лицо его собеседника, на котором появляетсн улыбка, - причем улыбка появляется не одновременно с произнесением остроты, а после того как она произнесена, хотя при әтом имеется в виду, конечно, передать именно одновременную реакцик.

В отношении различия времени в театре и в литературе любопытно замечание Гёте о сюжетных неувязках у Шекспира. Гёте объясняет их тем, что Шекспир писал не для чтения, а для сцены, с характерной для последней сгущенностью времени (и, добавим, невозможностью вернуться назад, как можно вернуться к раз уже прочитанному), т.е. для такой ситуации, когда « е к о г а останавливаться и критиковать подробности (см.: Гёте, 1905, c. $338-341)$.

36 См., в частности: Уитроу, 1964, с. $109-149$.

37 См., например, клейма на иконах, временну́ю последовательность фрескового ансамбля или же иконописное изображение ґсекновения главы Иоанна Предтечи*, где тело Предтечи изображено на фоне одного пейзажа и в пределах одних рамок - в нескольких различных временны́х моментах. Специально о передаче временно́й последовательности в иконописи см. с. 265 и сл. наст. изд.

38 С. моделирование обратного времени у О.Э.Мандельштама: «Быть может, прежде губ уже родился шепот и в бездревесности кружилися листы... (*И Шуберт на воде....). Подробнее о Мандельптаме в этой связи см.: Успенский, 1994 а, с. 142 (примеч. 5), с. 162 (примеч. 47). 
мени. Это никак невозможно, однако, в других видах искусства (литература, кино и т.д.), где направление времени задано. Очевидно, что указанная свобода является непосредственным следствием именно того, что время относительно мало релевантно для изобразительного искусства.

Можно отметить в этой же связи, что ограниченные возможности в выражении времени имеют своим следствием то специфическое для изобразительного искусства обстоятельство, что/в процессе восприятия картины (изображения) не создаются или создаются относительно мало новые знаки/(как это часто имеет место при восприятии литературного произведения). Иначе говоря,/здесь менее характерна и г р а между автором (художником) и адресатом (в данном случае зрителем) произведения/(см. ниже, главу шестую).

Итак, специфика передачи пространства в том или ином литературном произведении определяется, в частности, степенью конкретности пространственных характеристик.

Если эта степень достаточно велика (т.е. если произведение характеризуется достаточной пространственной определенностью), возникает возможность конкретного пространственного представления излагаемого содержания; соответственно, тогда возможно и п е р е в е с и данное содержание из литературы в живопись, в театр и т.П. Но вовсе не всегда такой перевод возможен, так как пространственная определенность не всегда входит. в композиционные задачи автора. Анализируя гоголевский ННс, Ю.М.Лотман справедливо пишет, что «то, что у носа есть лицо, что он ходит, согнувшись, бежит вверх по лестнице, носит мундир, шитый золотом и со стоячим воротничком, молится „с выражением величайшей набожности“... решительно разрушает возможность какоголибо пространственного (зрительно-объемного) его воображения ${ }^{39}$.

Совершенно очевидно, в самом деле, что произведение такого рода невозможно инсценировать или әкранизировать точно так же, как нельзя, строго говоря, экранизировать и сказку: специфика театра (или кино) требует конкретизации таких характеристик, которые могут считаться просто нерелевантными в литературном произведении.

39 Лотман, 1968, с. 39. Ср. в әтой связи еще замечания Ю.Н.Тынянова: Тынянов, 1965, с. 173 (примеч. 3), а также: Тынянов, 1928, гл. 13. 
Пример с гоголевским «Носом очень нагляден, поскольку превращения .Носа бросаются в глаза; кроме того, здесь речь идет не только о его пространственной неопределенности, но и о расплывчатости в самых разных планах.

В других же случаях отсутствие пространственной апределенности не так очевидно и обнаруживается лишь при внимательном чтении; иначе говоря, при вчитывании в текст может оказаться, что та или иная фигура несколько изменила свои размеры по отношению к окружающим ее фигурам или объектам - или же в равной мере можно считать в этом случае, что размер этих последних изменился по отношению к первой фигуре.

Именно в этом смысле, например, лишена пространственной определенности фигура кота в “Мастере и Маргарите М.Булгакова. Соотносительность его размеров с размерами других фигур и объектов меняется на протяжении повествования (хотя мы можем судить об этом лишь по косвенным данным). Иногда мы можем думать, что его фигура - обыкновенных кошачьих размеров; в других же случаях фигура его незаметно как бы вырастает, он производит такие действия, для которых требуются размеры явно бо́льшие: подходит к столу, наливает из графина воду, берет билет у кондуктора и т.п.

Точно так же могут меняться размеры героев в фольклоре 40 причем эти различия совсем не обязательно акцентируются: напротив, часто на них вообще не обращается внимания. Таким образом, речь идет не столько о каком-либо фантастическом превращении, сколько об отсутствии пространственной определенности: соотношения размеров могут быть вообще нерелевантными для повествователя.

В этой же связи могут быть приведены и известные случаи некоординированности описания у Гоголя (Чичиков в «Мертвых ду: шах разъезжает летом в шубе, Манилов также носит шубу и шапку с наушниками; Ковалев в «Носе в марте месяце в Петербурге видит девушку в белом платье, Нос ездит в одном мундире и т.п. ${ }^{41}$ ), которые можно трактовать как случаи именно пространственной несоотнесенности (разумеетс, не намеренной, а обусловленной тем, что пространственная конкретизация нерелевантна для автора).

40 См.: Неклюдов, 1966.

41 См.: Волошин, 1933; cp. тажже: Бузескул, 1911. 
Все вышеприведевные случаи - и вообще случаи подобного рода - могут быть интерпретированы как с л у и и и о т с у ствия пространственной определенности позиции повествователя (ваблюдателя)/ в ряде случаев можно считать, что разные фигуры в повествовании имеют различных - ве сообщающихся друг с другом - наблюдателей (причем результаты наблюдения затем монтируются автором $)^{42}$. (Типологическую вналогию этому в живописи имеем в случае обратной перспективы ${ }^{43}$.)

В связи со сказанвым выше понятно между тем, что /в p e м е н в я неопеделевность 44 для произведений литературы гораздо менее характерна, чем неопределенность пространственная; обратное наблюдаем в изобразительвом искусстве.

42 В равной мере можно было бы считать, с другой стороны, что әти фигуры находятся в разных пространствах, лишь частично между собой соотнесенных. Оба подхода не отличаются по свонм результатам.

43 Ср. с. $246-263$ наст. изд.

44 Под временно́й определенностью понимается здесь исключительно относительная хронология события. В прочих же аспектах может констатироваться в известных условиях и достаточная неопределенность. Ср., например, абсолютную (а не относительную) неопределенность времени в Гамлете Шекспира, которая не раз отмечалась исследователями (мы не знаем в точности, сколько времени проходит на протяжении действия драмы; известно, что в начале действия Гамлет молодой студент, а в конце ему тридцать лет, - нам же действие показывается как непрерывное). 


\section{4 „Точки зрения“ в плане психологии}

Когда автор строит свое повествование, перед ним, вообще говоря, открыты две возможности: он может вести описание со ссылкой на то или иное индивидуальное сознание, т.е. использовать какую-то заведомо с у б ъ е к т и в у ю точку зрения, - или же описывать события по возможности о б з к т и в о. Иначе говоря, он может оперировать данными какого-то в о с п р и я т и я (или нескольких восприятий) или же известными ему Ф а к т а м и. (Разумеется, возможны и разнообразные комбинации указанных принципов, т.е. различные чередования авторской позиции в указанном отношении.)

Сказанное верно как в отношении художественной литературы, так и в отношении повседневного (бытового) рассказа. Действительно, когда мы рассказываем о том или ином событии, которому сами были свидетелями, мы неизбежно сталкиваемся с дилеммой: рассказывать ли только то, что мы сами непосредственно видели, т.е. Ф а к т ы, либо реконструировать внутреннее состояние действующих лищ, мотивы, которые руководили их действиями, но не были доступны внешнему наблюдению-т.е. принимать во внимание их собственную (внутреннюю) точку зрения. (Обыкновенно при этом мы пользуемся как тем, так и другим приемом, соответственно комбинируя наш рассказ.) Так же и в произведениях художественной литературы: персонажи даются описанными либо с первой, либо со второй точки зрения.

В тех случаях, когда авторская точка зрения опирается на то или иное индивидуальное сознание (восприятие), мы будем говорить о п с и х о л о г и ч е с к о й точке зрения; самый же план, на котором проявляется соответствующее различение точек зрения мы будем условно называть п л а н м І с и хо л о г и.

Мы уже имели случай, вообще говоря, наблюдать ссылку на чье-то субъективное сознание при описании - в связи с рассмотрением плана фразеологии. Действительно, такое явление, например, как несобственно-прямая речь, во многих случаях представляет собой не что иное, кпк использование некоторой субъективной позиции, т.е. ссылку на сознание какого-то персонажа, - которая проявляется фразеологически. В определенных случаях можно даже 
считать, что план психологии выражается здесь фразеологическими средствами - подобно тому, как может выражаться через фразеологию план идеологии ${ }^{1}$, или подобно тому, как план идеологии может быть выражев через временну́⿴囗 позицию повествователя ${ }^{2}$.

Нас, однако, будет сейчас интересовать план психологии сам по себе и специфические средства выражения различных точек зрения в этом плане.

Приведем конкретный пример, демонстрирующий возможности ссубъективного (т.е. использугщего чье-то индивидуальное восприятие, некоторую психологическую точку зрения) и собъективного описания некоторого события. Вот как описывает Достоевский в «Идиоте сцену покушения Рогожина на жизнь князя:

Глаза Рогожина засверкали, и бешеная улыбка исказила его лицо. Правая рука его поднялась, и ч т о - т о блеснуло в ней; князь не думал ее останавливать (т. VIII, c. 195).

Двумя абзацами ниже то же событие описывается с существенно отличной точки зрения.

Надо предположить, - пишет автор, - что... впечатление внезапного ужаса, сопряженного со всеми другими страшными впечатлениями той минуты, вдруг оцепенили Рогожина на месте и тем спасли князя от неизбежного удара н о ж о м, на него уже падавшего.

Так мы уэнаем, что предмет, блеснувший в руке Рогожина, был нож.

Итак, одно и то же событие здесь описано двумя принципиально различными способами. В одном случае имеет место субъективное описание, ссылка на восприятие квязя, т.е. использовавие его психологической точки зрения; соответственно о ноже здесь говорится что-то», т.е., По-видимому, так, как он был воспринят в тот момент князем; автору как бы неизвестно еще, что это за предмет, ов целиком присоединяется в данный момент к точке зрения князя (отсюда и характерная синхронность точки зрения, с которой ведется повествование: о ноже говорится ччто-то именво по'ому, что князь - а вместе с ним и автор - е щ е не знает, что это; через мгновение это, конечно, станет совершенно очевидным).

1 См. выше, с. 27-29.

2 См. выше, с. 94-95. 
Между тем во втором случае описание покушения ведется с объективных позиций, т.е. излагаются факты, а не впечатления; автор основывается здесь на своей собственной точке зрения, а не на точке зрения князя (позтому на әтот раз он повествует с ретроспективной, а не синхронной позиции).

С известной натяжкой можно еще считать, что в первом случае имеетя әлемент использования фразеологии для передачи психологической точки зрения, т.е. трактовать слово «что-то как вкрапление из внутреннего монолога князя (пусть не произнесенного реально, но воображаемого).

Непосредственно ниже мы перейдем к рассмотрению случаев, когда психологическая точка зрения заведомо никак не связана с планом фразеологии, т.е. таких случаев, когда план психологии выступает в наиболее чистом виде, а проявление точек зрения в әтом плане характеризуется свонми специальными средствами выражения.

Способы описания поведения в связи с планом психологан

Поведение человека, вообще говоря, может быть описано двумя принципиально различными образами:

1. С точки зрения какого-то посто рон него н а 6 л г д а т л я (место которого может быть как четко определено, так и не фиксировано в произведении). В этом случае описывается лишь то поведение, которое доступно наблюдению со стороны.

2. С точки зрения его самого - либо всевидящего наблюдателя, которому дано проникнуть в его внутреннее состояние. В әтом случае описывактся такие процессы (чувства, мысли, ощущения, переживания и т.п.), которые в принципе не могут быть доступны наблюдению со стороны (но о которых посторонний наблюдатель может лишь догадываться, проецируя внешние черты поведения другого человека на свой субъективный опыт). Иначе говоря, речь идет о некоторой в н т р е н н й (по отношению к описываемому лицу) точке зрения.

Соответственно можно говорить в данном случае о в н е II н е й и в в у т р е н е й (по отношению к объекту описання) точке эрения ${ }^{3}$. Следует оговориться при этом, что противопостав-

${ }^{3} \mathrm{Cp}$. очень характерное зяявление рассказчика в «Бесах Достоевского: «Разумеется, я не знаю, что было в нут р и человека, я в и дел сна- 
ление внешней и внутренней (своей и чужой) точки арения имеет гораздо более общий характер, отнюдь не ограничиваясь одним планом психологии 4 . Отчасти мы уже имели возможность наблюдать данное противопоставление при рассмотрении плана фразеологии и других планов. Ниже противопоставление внешней и внутренней точки зрения будет обобщено в специяльном разделе.

В настоящей главе мы пользуемся терминами «внешняя" и "внутренняя точка зрения исключительно в том узком смысле, какое это противопоставление приобретает в плане психологии, имея в виду затем раскрыть более общий характер данных терминов (см. главу седьмую).

\author{
Первьй тип \\ отисания поведения: \\ внешняя \\ (по отвошенню \\ к опнываемому лицу) \\ точка зрения
}

Обратимся сначала к первой из указанных выше возможностей. Поведение человека может описываться в этом случяе:

a) со ссылкой на определенные факты, не зависящие от описывающего субъекта (соответственно место наблюдения принципиально не фиксировано, само описание имеет безличный - или, если угодно, надличный характер) - например, так, как описывается поведение в судебном протоколе ${ }^{5}$, т.е. с использованием фраз тина: *он сделал...*, *он сказал...* (или даже *он заявил...,, с нарочитым подчеркиванием объективизации описания, непричаст-

р у ж и॰ (т. X, с. 166) - признание, которое, впрочем, отнюдь не мешавт тому же рассказчику в других случаях становиться на другую точку зрения, ведя повествование не чснаружи*, а изнутри".

${ }^{4}$ Ниже мы убедимся, что противопоставление внутренней и внешней точек зрения существенно не только для художественной литературы, но и для изобразительного искусства (см. с. 173 наст. изд.).

5 Для судебного протокола вообще характерно устранение всякого субъективного момента, т.е. максимальное приближение к объективному описанию. Составителю протокола надлежит выразиться, $k$ примеру, не $X$ увидел незнакомого ему военного , но $\boldsymbol{X}$ увидел незнакомого ему человека в военной форме , так как первая фраза содержит, хотя бы в минимальной степени, субъективный оттенок (знание того, что данный человек - действительно военный). 
В этом случае в описании могут встретиться специальные выражения, описывающие внутреннее состояние, в частности, verba sentiendi ${ }^{6}$ и др.: «он подумал... , «он почувствовал... , «ему показалось...», «он знал...», фон вспомнил... и т.п.

Соответственно, формальвым признаком данного типа описания (использования «внутренней точки зрения) является употребление в тексте специальных глаголов внутреннего состояния. Слова такого типа маркированы в языке и легко могут быть заданы в виде относительно небольшого списка, что делает возможным формальное выявление структуры литературного произведения в исследуемом аспекте.

Между тем, показательным признаком, позволяющим констатировать противоположный тип описания - использование точки зрения постороннего наблюдателя, - может считаться употребление в тексте специальных модальных слов типа: «видимо*, *очевидно», «как будто», «азалось» и т.п. Действительно, слова этого типа появляются в тексте именно в том случае, когда повествователь описывяет то, чего он не может знать наверное, - в частности, когда он описывает чье-то внутреннее состояние (будь то мысли, чувства, бессознательные мотивы поступков) с точки зрения постороннего наблюдателя.

Иначе говоря, речь идет о ситуации, когда в композиционные задачи автора не входит использование внутренней точки зрения по отношению к данному персонажу, он изображается в произведении извне (например, через чье-то восприятие) - но при этом автору нужно каким-то способом передать переживание данного лица. В этом случае глаголы внутреннего состояния при описании данного персонажа могут сойровождаться вводными словами указанного типа (т.е. говорится: «Он, к а а а л с ь, подумал...», *N.N. к а к б у д т о хотел... и т.д.). Последние, тем самым, играют роль специальных о п р а т о о в, которые позволяют п е ре в о д т ь выражения, описывающие внутреннее состояние, в план объективного описания (иными словами, трансформировать описание изнутри в описание извне) ${ }^{7}$.

Таким образом, указанные слова-операторы используются автором как специальный прием, функция которого - оправдать

6 Verba sentiendi букв. - глаголы ощущения.

7 Ср. выше (на с. 53-54) выделение специальных операторов («слов-кавычек»), которые позволяют переводить прямую речь в план авторской речи (в пределах сложноподчиненного предложения). 
тором как специальный прием, функция которого - оправдать применение глаголов внутреннего состояния по отношению к лицу, которое, вообще говоря, описывается с какой-то посторонней (“остраненной ) точки зрения ${ }^{8}$. Их можно называть соответственно нс л о в а м и ост ра не н и ян.

Приведем примеры из «Войны и мира (сцена в доме Ростовых в день именин графини, когда дети убежали в гостиную):

...все разместились в гостиной и, в и д и м о, старались удержать в границах приличия оживление и веселость, которыми еще дышала каждая их черта (т. IX, с. 48).

...толстый мальчик сердито побежал за ними, как б у д т досадуя на расстройство, происшедшее в его занятиях (т. IX, с. 49).

Подобных примеров можно привести очень много, даже если ограничиться только «Войной и миром»; этот принцип описания вообще очень характерен для Толстого (нам еще придется к нему возвращаться). Существенно, что в каждом из приведенных случаев Толстой вполне мог бы и опустить соответствующее вводное слово - без какого-либо нарушения образа описываемых персонажей. Данные слова употребляются им не потому, что автор не уверен в действительных ощущениях персонажей, - но именно с тем, чтобы указать на точку зрения, с которой ведется описание. Это может быть, например, точка зрения гостей графини или какого-то

В Заметим, что в аналогичной функции может выступать подчеркнутый переход на ретроспективную позицию (которая дает право знать то, что не может быть известно при синхронной позиции наблюдателя). Такой пркем (наряду с другими) особенно характерен, в частности, для Достоевского. См., например, сцену свидания в больнице Алеши и Кати с Митей в «Братьях Карамазовых $\$$. Изложение ведется, в общем, с точки зрения Алеши. Неожиданно появляется Грушенька. «ошла она, как о ка а лос ь п о о м, совсем нечаянно , - пишет Достоевский (т. XV, с. 189). Автору нужно сообщкть, что Грушенька вошла непреднамеренно, но он не может сказать вто просто, без специяльной оговорки, - принятая им здесь манера изложения требует указать, откуда әто ему известно (поскольку носитель авторской точки зрения, Алеша, в тот момент әтого знать еще не может). Переход на ретроспективную позицию служит для оправдания авторского знания - и соответственно для оправдания описания с внутренней, а не с внешней точки зрения (о ретроспективной позиции как позиции, дающей право все знать, - см. ниже, с. 128). Этот прием в данной функции вообще довольно часто используется Достоевским (ср. также ниже, с. 122-123, об описании Ивана Карамазова). 
воображаемого постороннего наблюдателя, незримо присутствующего в комнате (с позиции которого производится остранение).

Подобное указание на ччужую точку зрения не менее характерно, чем, например, индивидуальное слово в авторском контексте, позволяющее фиксировать использование той или иной точки зрения в плане фразеологии. Оба приема имеют, в общем, одинаковую функцию, но принадлежат разным планам.

Необходимо заметить, что слова подобного рода со всей очевидностью указывают на некоторого с и н $\mathbf{p}$ о н о о о наблюдателя, присутствующего на месте действия ${ }^{9}$; тем самым можно сказать, что эти слова фиксируют не только психологическую, но и пространственно-временну́ ю точку зрения.

Итак, наличие в тексте выражений, описывающих внутреннее состояние без специальных оговорок вышеприведенного типа, указывает на использование внутренней точки зрения; соответственно, признаком внешней точки зрения является отсутствие выражений внутреннего состояния или же наличие в тексте специальных слов-операторов («слов остранения»).

При формальном проведении данного анализа следует учитывать, конечно, и возможность әллипсиса соответствугоего «слова остранения (особенно в тех случаях, когда его присутствие достаточно предсказуемо из общего контекста). Ср., например, следугщи отрывок из «Братьев Карамазовых :

Федор Павлович... с насмешливого улыбочкой следил за своим соседом Петром Александровкчем и, в и д и $\mathbf{M}$, радовался его раздражительности. Он давно уже собирался отплатить ему кое за что и теперь не хотел упустить случая (т. XIV, c. 55).

Можно предположить, что слово «видимо или «как будто отсутствует во втором предложении, так как ово имеется в предложении предыдущем, т.е. по причннам чисто стилистическим, а не композиционным.

${ }^{9}$ В качестве такого наблюдателя можкет предполагаться кто-то из участников действия (и именно тот, к кому применяется описание внутреннего состояния), но может быть и такой случай, когда все действующие лица даны в остранении. В атом случае, по-видимому, автор ведет повествование с позидии стороннего наблюдателя, незримо присутствующего на месте действия, но не участвующего в действии, - т.е. со спедиальной позидии рассказчика (см. подробнее ниже, в главе пятой). 


\section{Тнпология композиционного использования различных точек зрения в плане психологии}

Итак, мы выделили два принципа, два приема описания, которые условно обозначили как описание извне и описание изнутри (напомним, что это противопоставление рассматривается сейчас исключительно в плане психологии). Построения произведевий художественной литературы различаются в указанном отношении. Рассмотрим различные возможные здесь случаи (нумеру́я их в последовательном порядке).

Случай I.

Oтсутствне смены авторской позицип IpH повествованин: собьектионоен описание

В наиболее простом (с точки зрения композиции) случве в произведении последовательно применяется способ внешнего описания. Все события описываются тогда в терминах объективных поступков без какой-либо ссылки на внутреннее состояние персонажей. Соответственно глаголы, выражающие внутреннее состояние, здесь отсутствуют вовсе.

Такое построение повествования особенно характерно для эпоса (ср. типичную для эпического произведения внешнюю немотивированвость поступков, которая в большой степени объясняется тем, что внутренний мир действующих лиц от нас скрыт).

Cлуучай $\mathbf{\Pi}$.

Orcyтcтвпе cмenu antopcicoü mo3ruyn пра повествованит:

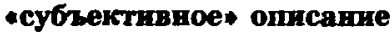

В этом случае все действие в произведении последовательно изображается с какой-то о д н о й точки зрения, т.е. через призму восприятия одного какого-то лица. Соответственно лишь в отношении этого лица правомерно описание внутреннего состояния, тогда как все остальные должны описываться *извне , а не *изнутри . 
Повествование в этом случае может быть дано с точки зрения рассказчика (тогда рассказ ведется от п е р в о г лица, т.е. имеет место Icherzählung) либо с точки зрения какого-то определенного персонажа данного произведения (тогда рассказ ведется от т р е т ь г о лица). Последнее можно представить как специальный случай преобразования Icherzälung, а именно когда местоимение первого лица заменяется некоторым собственным именем или описательным обозначением.

Такое построение очень обычно в литературе; особенно часто оно встречается в относительно небольших новеллах ${ }^{10}$. В качестве примера можно привести •Вечного мужа Достоевского, где все дается через восприятие Вельчанинова. Соответственно поведение всех остальных персонажей дается с точки зрения 4извне», тогда как его поведение анализируется и освещается с внутренней по отношению к нему самому точки зрения.

Во многих случаях, когда повествование производится с точки зрения одного какого-то человека (безразлично, будь то เя • или некий $X$ ), этот человек и выступвет в качестве главного героя данного произведения; автор - а вместе с иим п читатель - как бы солидаризируется с ним, вљживается в его образ. Иногда при әтом подспудной композициовной задачей произведения может являться показ этого человека («я или $X$ ) глазами внешнего наблюдателя, со стороны. Иначе говоря, данный человек дается изнутрин, но все повествование направлено на то, чтобы читатель мог взглянуть на него глазами других, т.е. реконструнровать взгляд иивне на него. (Так строятся некоторые вещи Хемингуэя, написанные от первого лица ${ }^{11}$.) Этот случай может быть интерпретировав как случай несовпадения композиционно структуры произведения на психологическом и на идеологическом уровнях (см. подробнее главу пятую).

С другой стороны, главным героем может выступать не само лидо, впечатления которого описываются в произведении, а кто-то другой (например, Натали в одноименном рассказе Бунина, Павел Павлович в •Вечном муже и т.п.). Таким образом, герой может быть показан способом внешнего описания, но при этом задачей произведения является заставить читателя представить его иизнут-

10 Оно очень характерно, в частности, для Бунина и для целого ряда других новеллистов.

11 Это вообще характерно для романтического мировоззрения (4романтическое понимается тут как пронзводное от номантика», а не от "романтизм). Ср. определение психологического типа романтика в работе: Пятигорский и Успенский, 1967, с. 22. 
риः; между тем то лицо, через которое ведется повествовавие (и которое описывается соответственно с внутревней тодки зрения), может выступать как фигура чисто вспомогательная, не укладывајощаяся в какой-либо ковкретный образ (так, например, мы едва ли можем представить себе со стороны рассказчика в - Бесах म Достоевского, Антона Лаврентьевича Г-ва, хотя ов и принимает участие в дейСтвин).

В рассмотренных выше случаях (I и II) - их можно было бы называть случаями «последовательного описания - позиция наблюдателя, с точки зрения которого пронзводится описание, в п р и ц и п е ре а л н а. Автор описывает поведение своих героев так, как обычно человек в нормальной ситуации опишет поведение другого человека, - в частности, так, как один из его героев может описать поведение другого. Автор, таким образом, ставит себя на одну доску с персонажами, никак среди них не выделяясь. При этом он может описывать события со своей особой точки зрения или соединяться (склеиватъся) с каким-то другим лицом, с точки зрения которого ведется повествование. Существенно, что в этом случае автор может быть таким же участником событий, как и любой из его героев.

В других же случаях (случаи III и IV, к рассмотрению которых мы переходим) позиция автора менее последовательна и менее реальна, существенно отличаясь от позиции повседневного наблюдателя. Автор здесь использует в описании не одну, а н е ск о л ь к о точек зрения, причем различные точки зрения могут последовательно сменять друг друга на протяжении повествования (случай III) или же участвовать одновременно (случай IV).

\author{
Cryquĭ II. \\ Mnoscecteeniocts \\ тоgex зредия \\ Ipa noвectвoвanm: \\ cmean abtopcicrix \\ позиций
}

При последовательном использовании различных точек зрения в произведении каждая сцена описывается с одной какой-то позиции (точки зрения), но разные сцены описываются с позиций разных героев. 
При таком описании лицо $A$ описывается с точки зрения лица $B$, а вслед за тем и $B$ может быть описано через восприятие $A^{12}$; но существенно, что внутреннее состояние $A$ и $B$ не может описываться одновременно в одной и той же ситуации (микросцене): тогда это будет случай IV.

Таким образом, автор в каждом случае как бы присоединяется к точке зрения одного из действующих лиц, как бы участвует в действии, последовательно переходя от одной точки зрения к другой в своем повествовании (причем помимо точек зрения действующих лиц он может в какой-то момент принимать и свою собственную, т.е. авторскую точку зрения ${ }^{13}$ ).

При этом каждый раз к очередному носителю авторского ви́дения применимы глаголы внутреннего состояния, тогда как действия других людей описываются так, как видит их данный носитель.

Так, например, повествование в Войне и мире строится на последовательном чередовании точек зрения Пьера, Наташи, Николая и других. Обычно чередование точек зрения обусловлено сюжетными кусками повествования, т.е. одна сцена дается с точки зрения одного персонажа, другая - с точки зрения другого и т.п.; иногда, однако, последовательное чередование точек эрения имеет место по мере развертывания событий в одной и той же сцене. Примером может служить описание вечера в доме Ростовых после карточного проигрыша Николая - когда Наташа поет, а Николай ее слушает; здесь попеременно меняются точки зрения Наташи и Николая (см.: т. X, с. 58-59). Таким образом, ритмы композиционных переходов здесь убыстряются: смена точек зрения, которая, вообще говоря, соответствует в романе достаточно большим кускам повествования, происходит здесь на протяжении небольшого промежутка времени (это нагнетание ритмов в большой степени отвечает тому, что происходит в это время в душе Николая ${ }^{14}$ ).

При рассматриваемом построении повествования текст всего произведения в целом как бы расдадается на от -

- 12 Подобный способ композиционной организадии очень обычен в киноповествовании. В голливудских коммерческих фильмах әтот прием имеет характер обязательной нормы.

13 Последний прием, как и вообще смена авторской позиции, часто используется в функции композиционной рамки - см. об әтом ниже (с. 181 и сл.).

$14 \mathrm{Cp}$. также аналогичное чередование точек зрения в диалоге Бориса и Пьера (т. IX, с. 65-67). Вдесь, однако, подобное сгущение ритмов никак не обусловлено внутренним состоянием действующих лиц. 
де льны е о п и с а н и я, данные с точки зрения разных лиц, представляя собой - в интересующем нас аспекте - соположение этих отдельных текстов, но не их синтез.

Заметим, что подобную организацию текста можно получить путем ряда последовательных преобразований вескольких повествований от первого лица, когда первое лицо в этих повествованиях заменяется на третье, а текст целого произведения последовательно составляется из выборочных кусков этих повествований.

Вообще напболее отчетливо указанный привцип выступает в трививльном случае, когда разные части пропзведении даготся от имени развых героев - каждый из которых ведет повествование непосредственно от первого лица (вапример, *Лунный камень У.Коллинза или -Два капитана В.Каверина); такая композиция восходит, повидимому, к роману в письмах. По сравневию с әтим случаем только что рассмотренная ситуация, когда в разных сценах различные персонажи последовательно становятся носителями авторского ви́девия, может трактоваться как очередная ступень в последовательных усложнениях композиция (восходящих в свокх истоках к Icherzahlung как к наиболее әлементарной композиционной возможности).

Понятно, что использование различных действующих лиц в функции носителей авторской точки зрения может сочетаться в произведении и с собственно авторским «я", т.е. В произведении могут соприсутствовать как сам автор (повествующий от своего лица и, соответственно, со своей собственной или какой-то специально принятой им точки зрения), так и окказиональные восприемники авторской точки зрения (в лице тех или иных персонажей данного произведения). Такое сочетание нередко у Достоевского (примером могут служить хотя бы «Братья Карамазовы ).

Важно отметить, что позиция повествователя в рассматриваемом случае о тносит ельно ре а льн здесь как бы незримо участвует в действии, он как бы ведет репортаж непосредственно с поля действия - и, таким образом, его место может быть каждый раз с большей или меньшей точностью фиксировано в пространственных и временны́ координатах. (Можно сказать, что позиция автора здесь относительно менее реальна и последовательна, чем в случаях I и II, но, однако, более реальна, чем в случае IV, о котором речь будет идти ниже.)

Если рассматривать типологические возможности композиционного построения с использованием различных последовательно 
чередующихся точек зрения, следует прежде всего обратить внимание на то, что число тех лиц, с точки зрения которых строится повествование, может быть функционально ограничено.

Иначе говоря, в образы одних персонажей автор в и в а е т с я, он, хотя бы на некоторое время, отождествляет себя с ними; можно сказать, что он как бы уподобляется актеру, играющему роль этих людей и перевоплощающемуся в их образ. Тем самым становится логически правомерным описывать внутреннее состояние этих персонажей.

Если в образы одних персонажей автор может на время перевоплощаться, то другие персонажи в произведении могут, напротив, оставаться для него воспринимаемыми чисто внешне, со стороны: он пишет их портрет, но не вживается в их образ. Иначе говоря, если одни персонажи в произведении могут выступать в роли с у бъ е т а авторского восприятия, то другие персонажи составляют исключительно его о 6 ъ е к т.

Естественно, что восприемниками авторской точки зрения часто становятся главные герои, тогда как лица малозначительные или эпизодические, составляющие фон (так сказатъ, статисты), не получают права на описание внутреннего состояния, изображаются извне.

Так, однако, бывает отнюдь не всегда: в определенных случаях автору может быть важно, напротив, показать своего героя глазами других, а не раскрывать самому его внутреннюю сущность; автор может предоставлять самому читателю догадываться о чувствах и мыслях своего героя, изображая его в какой-то степени з а г а д ч н ы м. Таким образом (пусть это не покажется парадоксом), прием описания *со стороны может быть применен как в том случае, когда персонаж не представляет интереса для автора, так и в том случае, когда данное лицо, напротив, представляет для него предмет специального интереса.

Последний случай может быть иллюстрирован на примере описания таких фигур, как Платов Каратаев у Толстого или старец Зосима у Достоевского. Действительно, все действия и того и другого описываются с какой-то внешней точки зрения - в частности, так, как они были восприняты другими людьми (Пьером, Алешей): каждый раз, когда по отношению к ним употребляются глаголы внутреннего состояния или дается мотивация их поступков, в описание вводятся специальные слова остранения (типа *видимо*, *казалось и т.п.). Например, о Зосиме: „Он, о ч е в и д н о, не хотел (т. XIV, с. 56); „Он в и д и м оставал" (т. XIV, 
c. 66); „Иногда он пресекал говорить совсем, ка к 6 ы собираясь с силами, задыхался, но был к а б бы в восторге (т. XIV, c. 149). О Каратаеве: „Он в и д и м о был огорчен. (т. XII, с. 47); *Отрицательный ответ Пьера опять в и д и м о огорчил... (там же); «Он в и д и м о никогда не думал...* (т. XII, с. 49) и т.п. ${ }^{15}$.

Что касается Толстого, то этот принцип описания определенно контрастирует в •Войне и мире с описанием Пьера, относительно которого автор все время сообщает, что́ тот подумал и почувствовал. Понятно, что Каратаев представляет интерес для Толстого прежде всего как об ъ е к т описания, как некоторая 3 а $г$ а д к а, которую необходимо разрешить Пъеру; так же и Зосима у Достоевского.

Аналогичным образом описывается, например, и Смердяков в «Братьях Карамазовых . Он тоже преподается автором как некоторая загадка (хотя, конечно, загадка совершенно иного рода, чем Зосима и Каратаев), разрешить которую предстоит не непосредственно самому автору (путем проникновения в сознание описываемого им персонажа), но героям данного произведения.

Точно такой же принцип описания, наконец, применяет Достоевский по отношению к Ивану в „Братьях Карамазовых - на протяжении значительной части повествования. Действительно, долгое время Иван описывается исключительно извне, представая перед читателем лишь в своих поступках и во мнениях окружающих: он для читателя загадка, так же как загадка он - эта "столичная штучка - и для обитателей Скотопригоньевска. Показательно, что в экспозиции романа, когда автор представляет читателю семью Карамазовых, он не считает возможным дать характеристику Ивана (при том, что нам дается определенная информация о характере других братьев Карамазовых), но излагает лишь с формальной стороны его биографию (причем излагает достаточно сухо, едва ли не протокольно); далее же Иван предстает нам в поведении (иногда нам непонятном) и во мнениях (других персонажей). Этот принцип описания явно контрастирует в произведении с описанием других братьев, мысли и чувства которых нам открыты.

Лишь после того как Иван Карамазов читает Алеше свою «Легенду о Великом Ннквизиторе , читатель время от времени (хотя

15 В единственном случае нарушения данной закономерности (см.: Толстой, т. XII, с. 46) может предполагаться аллипсис соответствующего вводного слова. 
поначалу и очень редко) получает право проникнуть в психологию Ивана (например, т. XIV, с. 241 и далее). Таким образом, «Легенда о Великом Инквизиторе выступает как момент в каком-то смысле переломный в описании Ивана (и соответственно в отношении к нему читателей). Это и понятно: в своем роде это исповедь Ивана, которая сближает его с читателем (и последний таким образом приобретает возможность воспринимать его не через мнение других, а непосредственно).

Характерна одна фраза, которой обмолвливается Достоевский, когда - еще на первых порах - слегка приоткрывает завесу мыслей и чувств Ивана. Описывается состояние последнего после разговора со Смердяковым, и автор говорит:

Но мы не станем передавать все течение его мыслей, д а и н е в рем я н а м в ходи т в в э т у д ушу: этой душе свой черед (т. XIV, c. 251$)^{16}$.

Автор как бы признается здесь, что описание внутреннего состояния героя пока еще расходится с композиционными задачами всего произведения; и, едва упомянув о переживаниях героя, рассказчик (о существовании которого читатель уже и забыл) появляется на сцене и подчеркивает свою о ткрове н н р те р о с п е т и в у ю позицию (противопоставленную предыдущему описанию, которое может восприниматься как произведенное с синхронной позиции). Тем самым здесь как бы подчеркивается, что с точки зрения «настоящего Ивана рассказчик не может

$16 \mathrm{Cp}$. близкую оговорку в *Бесах • Достоевского:

* Однако же ты... однако же ты мне әти слова должен выкупить, по д ум а л п о с е б я Петр Степанович, - и даже сегодня же вечером. Слишком ты много уж позволяешь себе“.

Так или почти так должен был задуматься П ет т С те п анович.... (т. X, с. 299; многоточие в прямой речи Достоевского).

В обоих случаях автор-рассказчик, употребив глагол внутреннего состояния, как бы спохватывается и напоминает о своем присутствии, чтобы сохранить принятый принцип описания. В задачи автора не входит использование психологической топки зрения соответствующего героя; с другой стороны, он не претендует на всезнание, а может только догадываться (или знать ретроспективно) о его мыслях. 
еще знать, что́ тот ощущал, - но может это сообщить нам, заглянув в его душу из его “будущего 17 .

Итак, в случае с Иваном Карамазовым мы имеем смену авторской позиции по отношению к герою, причем смену постепенную и идущую по мере постепенного знакомства читателя с Иваном - в ваправлении от описания физвне к описанию «изнури . В иных случаях смена авторской позиции может происходить и в обратном направлении, причем здесь может возникать довольно парадоксальная ситуация, когда наше подробное звание о мыслях и чувствах некоторого персонажа неожиданно вдруг сменяется описанием его же с внешней стороны. Читатель, который только что был ближайшим конфидентом персонажа, был досконально посвящен во все его переживания, знал мотивы всех его поступков, вдруг как бы оказывается с ним незнакомым, занимая принципиально иную (противоположную) позицию ${ }^{18}$. Это может приводить даже к логической неувязке, когда про героя, который нам очень близок, неожиданно мы узнаем (со стороны) что-то крайне важное - такое, о чем мы не можем не знать, коль скоро мы посвящены в мир его переживаний.

В качестве элементарного (и намеренно утрированного) примера можно представить себе детектив, сосредоточенный на поисках убийцы, причем в конце убийцей оказывается персонаж, который на протяжении всего действия выступал в качестве носителя авторской точки зрения (психологической) и - соответственно - в мир мыслей и чувств которого мы все время были посвящены. Понятно, что подобная композиция будет неудачна. Однако в менее откровенной форме она встречается не так редко.

Так, очень характерно, что про Дмитрия Карамазова - внутреннее состояние которого столь часто и столь подробно описывается и едва ли не каждое переживание которого нам как будто бы становится известно - вдруг выясняется неожиданная деталь: что он растратил не все деньги своей невесты, а половину спрятал у себя в ладанке, намереваясь их возвратить. Эта мысль, как оказывается потом, в с е в р е я я его занимает, он видит в ней спасение своей чести. Возникает естественный вопрос: почему же, если он столь много и часто об этом думает, мы, которые, вообще гово-

$17 \mathrm{Cp}$. такое же подчеркивание ретроспективной позиции повествования и далее (т. XIV, с. 254).

18 Такой прием может использоваться в специальной функции "рамки (см. ниже, с. 185). 
ря, посвящены в его внутреннее состояние, ничего об этом не знаем. Здесь своего рода противоречие.

Это противоречие можно понять как результат наложения двух композиционных задач повествования:

a) повествования с (психологической) точки зрения Дмитрия и

б) эффектного перераспределения информации, сокрытия от читателя каких-то данных с тем, чтобы преподнести их ему неожиданно, с эффектом (последний прием типичен для композиционного построения детектива) ${ }^{19}$.

Указанные две тендевции могут быть отмечены и в бытовом повествовании. Повседневный рассказ о тех или иных событиях, которые пережил рассказчик, может строиться в виде последовательного изложения того, что он воспринимал и ощущал в процессе данных событий, или же преподноситься слушателю в уже реорганизованном виде - с целью наиболее эффектного перераспределения информации.

В менее явной форме тот же принцип может быть прослежен в заключительной главе “Капитанской дочки Пушкина. Марья Ивановна Миронова едет в Царское Село хлопотать за своего жениха. На прогулке она встречает даму с собачкой и рассказывает ей о своем деле. В тот же день ее вызывағот во дворед, и там Марья Ивановна в государыне жузнала ...ту даму, с которой так откровенно изъяснялась она.... (Пушкин, т. VIII, с. 373). Так об этом сообщается читателю, но М.С.Альтман убедительно показывает, что сама Марья Ивановна фуже с первой встречи с дамой, прогуливавшейся в Царскосельском саду, догадалась, что это - государыня ${ }^{20}$. Итак, хотя описание и дается как будто со ссылкой на внутреннее состояние Марьи Ивановны, от читателя утапвается очень важная деталь опять-таки, для вящего ғффекта повествования. Это совсем не соответствует бесхитростному характеру самой Марьи Ивановны; создается впечатление, что verba sentiendi по существу используются в дан-

19 О приемах әффектного перераспределения информации см.: Выготский, 1968 (глава VII), где с атой точки зрения анализируется бунинский рассказ ^Легкое дыхание.. При атом Выготского интересует главным образом отношение последовательности изложенных позиций $\mathrm{k}$ последовательности событий реальных (фабулы к сюжету): он исследует, как реально (т.е. в изображаемой автором действительности) протекали события во временно́й последовательности, а затем показывает, в каком порядке излагает әту последовательность автор в своем рассказе.

20 См.: Альтман, 1971, с. 117-118. 
ном случае для описания со стороны. Указанное сочетание двух композиднонных задач пмеет здесь органический характер, поскольку перед намт (ретроспективныи) рассказ от лица П.А.Грпнева со слов Марьд Ивановны. Тем самым, мы вправе отнести ссылки на внутреннее состоянде геропни на счет рассказа самой Марын Ивановны, как бы легшего в основу данного әпизода, а аффектное перераспределение информации приписать непосредственному рассказчику - Гриневу.

Таким образом, мы можем различать следующие типы персонажей в произведевии:

а) Персонажи, которые не могут (в данном произведении) выступать в качестве носителей психологической точки зрения, т.е. такие, к которым не может быть применено описание «изнутри (но которые всегда описывајтся с точки зрения какого-то постороннего по отношению к ним наблюдателя).

б) Персонажи, которые не могут (в данном произведении) описываться глазами какого-то постороннего наблюдателя, т.е. такие, к которым не применяктся явные признаки *внешнего описания (слова типа «видимо», «как будто и т.п.). Следует оговориться, что при этом целесообразно исключить из рассмотрения начало и конец описания, когда признаки внешнего описания могут выполнять функцию «рамки (см. об этом ниже).

в) Персонажи, которые могут описываться в произведении как со своей собственной точки зрения, так и с точки зрения постороннего наблюдателя. Тем самым такой персонаж может быть как носителем авторского восприятия, так и его объектом.

г) Персонажи, которые, будучи раз изображены «изнутри , уже не могут быть изображены с точки зрения постороннего наблюдателя.

В разных произведениях могут встречаться различные наборы из указанных типов (причем какие-то типы, естественно, могут отсутствовать вовсе). Понятно, что использование того или иного персонажного типа определяется общими композиционными задачами, и тем самым характеристика персонажей в данном аспекте может служить средством для характеристики композиции соответствующего произведения. 


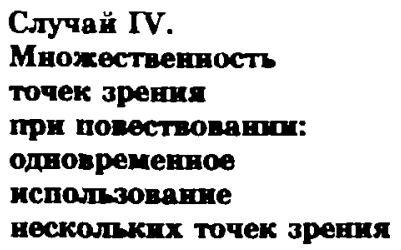

Наконец, возможно и такое совмещение рвзличных точек зрения при описания, когда одна и та же сцена описывается с нескольких разных точек зрения ${ }^{21}$. На интересующем нас уровне это проявляется в том, что в отношении р а 3 н х лиц, участвующих в одной и той же сцене, говорится не только то, что они сделали, но и то, что они подумали или почувствовали; иявче говоря, в этом случае о д н о ре м н н о опнсывается внутреннее состояние самых разных людей, что, очевидно, не может быть доступно внешнему наблюдению, даже при последовательном чередовании наблюдателей. При этом в данном случае, так же как и в предыдущем, таким образом могут описываться все лица, принимающие участие в описываемой сцене, или же некоторый ограниченный круг лиц, в то время как описания нстатистов даются извне.

В этом случае текст повествования непосредственно не распадается, как в предыдущем случае, на отдельные куски, данные с точки зрения разных людей. Повествование в целом здесь представляет собой с и н т е описаний, данных с разных точек зрения, а не простое их соположенне. Если предыдущий случай (случай III) можно сравнить с использованием разных источников света, каждый из которых освецает специально отведенный ему участок пространства, то настоящий случай (IV) естественно сравнить с рассеянным освецением, возникающим в результате одновременного использования сразу нескольких источников света 22 .

В описываемом случае повествователь не находится в позиции непосредственного участника действия. Он как бы ставит себя н а д д е й с т и е м - в такую позицию, что ему становятся доступны не только все поступки, но и все мысли и ощущения.

21 При известном подходе подобный случай мог бы рассматриваться как случай сложной (совмещенной) композиции, возникающей в результате взяимного наложения различных композиционных структур (см. об этом ниже, в главе пятой).

22 Заметим, что как тому, так и другому приему можно найти соответствие в изобразительном искусстве (см. ниже, с. 141-142). 
Можно сказать, что позиция автора здесь и р р е а л ь н а, он принимает точку зрения всевидящего и всезнающего наблюдателя. С другой стороны, его позиция может быть во многих случаях понята как ретрос пект и н а я: автор как бы повествует о делах давно уже пережитых (т.е. после того как он уже достаточно во всем разобрался post factum и может реконструировать внутреннее состояние действующих лиц, представив себе, кто что должен был испытывать) ${ }^{23}$.

Именно такой способ описания имеет место в «Братьях Карамазовых Достоевского в главе «Јуковка (т. XIV, с. 310 и далее), где описание дается с точки зрения рассказчика, Алеши, Грушеньки, Ракитина, или в главе «незапное решение (т. XIV, с. 357 и далее), где описание ведется с точки зрения Мити, Фени, Петра Ильича Перхотина. Точка зрения автора здесь как бы рассеивается, авторский объектив как бы скачет в беспорядочном движении, присоединяясь то к одному, то к другому из действующих в сцене лиц.

Можно было бы считать даже, что здесь имеет место последовательный переход от одного персонажа к другому (подобный тому, какой был описан в случае III), но конденсированный и убыстренный до такой степени, что теряются границы микроописаний с каких-то отдельных (фиксированных) точек зрения и описания эти нерасчленимо сливаются воедино. Можно сказать, что композиционный ритм произведения (определяемый частотой перехода от одной точки зрения к другой) ускоряется до предельной степени что может соответствовать внутреннему состоянию героев, принимающих участие в данной сцене. Действительно, подобный прием применяется Достоевским в моменты, соответствующие внутреннему перелому его героев, кульминации их душевного напряжения. Так, глава «Јуковка отражает внутренний перелом как у Алеши (после кончины старца Зосимы), так и у Грушеньки (приезд поляка, назревающая любовь к Мите). Глава «Внезапное решение описывает пере-

${ }^{23}$ Мы уже знаем из рассмотрения в предыдущей главе, что ретроспективная позиция повествователя вообще очень характерна для художественной литературы (так же как и для бытового рассказа). Лингвистически эта ретроспективность проявляется прежде всего в форме прошедшего времени, традиционно принятой при повествовании (в самых разных языках): в ряде языков имеется специяльная повествовательная видо-временна́я форма, относящаяся, как правило, к прошлому, - ср. французский (форма passé simple), хауса (форма suka) и т.д. (в русском языке, как уже говорилось, такой формой является форма несовершенного вида прошедшего времени). 
ломный момент у Мити (он узнал об отьезде Грушеньки, думает, что убил старика Григория, решил покончить с собой).

Таким образом, общая (синтетическая) точка зрения играет у Достоевского совершенно определеннук функциональную роль.

Bomathoctri травсформацтонного представле:пі paccuorperianx ewme cryqaes

Можно заметить, что из рассмотренных выше типов организации повествования три последних случая (а именно те, что связаны с внутренней точкой зрения какого-то лица или лиц) можно получить путем сочетания последовательно усложняющихся трансформаций из Icherzählung.

В самом деле, случай II, основываюцийся на последовательном описании внутренвего состояния одного какого-то человека (тогда как все остальные даются через его восприятие), - это может быть случай непосредственного Icherzählung или же случай, легко сводящийся к Icherzählung, а именво такой вид повествования, когда местоимение первого лица заменяется в тексте некоторым собственным именем или описательным обозначением (см. об этом выше).

Далее, в случае III, использующем переменную авторскую позицию (т.е. в том случае, когда имеет место несколько точек зрения, но при этом каждый фрагмент повествования последовательно дается с одной какой-то точки зрения), повествование распадается на отдельные куски, каждый из которых построен по способу II (т.е. сводится, в конечном счете, к Icherzählung).

Наконец, случай IV представляет собой, как уже говорилось, не соположение, но синтез описаний, построенных по способу II: различные описания (одной и той же сцены), произведенные с разных позиций, как бы нерасчленимо смешаны здесь воедино.

\section{Проблема \\ психодогической точки зрения как проблема авторского знания}

Рассмотренный только что подход - связанный с исследованием применения или неприменения глаголов внутреннего состоя- 
ния при описании того или иного персонажа - демонстрирует возможность формального анализа в данной сфере, но отнюдь не исчерпывает всех возможных проявлений точек зрения в плане психологии. Действительно, возможны и такие способы ссылки на то или иное субъективное сознание, которые не связаны с глаголами внутревнего состояния.

Мы уже приводили подобный пример, когда Достоевский описывает нож в руке Рогожина как некий блестящий предмет - в силу того, что он ссылвется на восприятие князя Мышкина, который в тот момент еще не успел осознать, что этот предмет нож ${ }^{24}$. Ср. еще несколько иной, но в принципе близкий случай из -Войны и мираः:

Через неделю после его [Пьера. - Б.У.] приезда молодой польский граф Вилларский, которого Пьер поверхностно знал по петербургскому свету, вошел вечером в его комнату с те м офиц и альным и тор жест ве н н м видом, с которым входи к н му секундант Долохова... (т. $\mathrm{X}$, c. 73).

Здесь явная ссылка на сознание Пьера, никак, однако, не связанная с использованием глаголов внутреннего состояния. Читателю самому по себе мало что говорит данная ассоциация, тем более что в свое время ему н е с о о 6 ш а л о с ь о том, с каким видом входил к Пьеру долоховский секундант. Әта ассоциация актуальна только для самого Пьера. Таким образом, здесь имеет место не столько описание того, с каким видом вошел в комнату граф Вилларский, сколько описание ассоциаций Пьера - в конечном счете, его внутреннего состояния. Следовательно, и этот случай должен быть отнесен к плану психологии.

Если обобщить все возможные проявления точек зрения в плане психологии, можно сказать, что центральным здесь является вопрос об а в т о р с о м 3 н а н и и и об источниках этого знания. Иначе говоря, речь идет о том, ставит ли себя автор в позицию человека, которому известно вообще все относительно описываемых событий, или же накладывает определенные о г р а н и ч е н и я на свои знания. В последнем случве нас должно интересовать, чем обусловлены данные ограничения. Они могут быть,

24 См. выше, с. 109. 
в частности, обусловлены тем, что автор становится на точку зрения какого-то действующего лица. С другой стороны, возможны и такие ограничения авторского знания, которые не связаны с принятием точки зрения того или иного персонажа; тогда мы можем говорить об особом рассказчике в произведении (именно эта ситуация характерна, в частности, для “сказа») 25 .

Нетрудно видеть, что проблема авторского знания, центральная в отношении плана психологии, в известных случаях может быть актуальной и для плана пространственно-временно́й характеристики. В то же время эта проблема совсем не актуальна для других планов, которые были рассмотрены выше 26 .

\section{Специфика различения точек зрения \\ в плане психологии}

Если в плане фразеологии различение точек зрения актуально вообще для самых разных родов литературы, то в плане психологии это различение неприменимо, например, к драме. Действительно, текст драмы состоит, как известно, из прямой речи плюс ремарок; при этом вся психологическая характеристика выносится в авторские ремарки. Между тем на сцене нам дается лишь «объективное поведение персонажа, т.е. его слова и поступки, и мы можем делать выводы о его внутреннем состоянии лишь піостольку, поскольку оно выражается в его поведении (в то же время, если мы читаем, а не смотрим пьесу, то психологическая характеристика персонажа, заключенная в авторских ремарках, становится нам доступной). Соответственно те действия в драме, которые по своей природе относятся к субъективному плану поведения (и

25 Ср. у Г.А.Гуковского: АТвлеченно-всеобъемлющий автор... берет себе право все знать - и то, что случилось со всеми его героями, и то, что они думают и чувствуют; это право или әта претензия на право составляет одну из серьезнейших и, пожалуй, труднейших проблем изучения литературы и в смысле того, откуда берется убедительность во всезнайстве автора для читателя, и в том, какой объективно идейный смысл имеет әто всезнайство в понимании самой действительности... (Гуковский, 1959, с. 47).

26 п поблеме сознательных ограничений, налагаемых автором на свое знание о повествуемых событиях, см. подробнее ниже, с. 218 , где ата проблема обсуждается в более общем плане - в связи с общей художественной концепцией соответствующего автора. 
которые тем самым могут быть фиксированы только посредством описания єизнутри ), - по необходимости переводятся в объективный план, т.е. в план внешнего поведения; иначе говоря, оба эти плана сливаются в драматическом произведении.

Отскда проистекает ряд характерных для драмы условностей. Внутренний монолог не отличается здесь от простого монолога, и если один персонаж говорит что-то на сцене "про себя - при этом, естественно, достаточно громко для того, чтобы его мог услышать зрительный зал, - то другой, стоящий рядом с вим, вообще говоря, не вправе его слышать. В то же время иногда в драме можно встретить и такую ситуацию, когда один персонаж говорит чтото про себя, а другой его п о д л у ш и а е т (злоупотребляя, таким образом, необходимой условностью театрального действия) ${ }^{27}$. Понятно, что и та и другая ситуация условны и вызваны именно специфическим для драмы совпадением субъективного и объективного поведения.

27 См., например, в русской драме XVIII века Юдифь:: Тихонравов, 1874 , с. 159 . Точно так же и в :Свадьбе Кречинского А.В.Сухово-Кобылина (акт I, явл. 12) Кречинский думает (слово „думает обозначено в авторской ремарке), а Нелькин нечаянно его подслушивает.

Сp. реакцию на такого рода условность в сочинении $\bullet$ Разные мнения о качествах комедианта и о первых предметах, которые вступающий в сие звание соблюдать должен (напечатанном в 1790-м г. -Собрании некоторых театральных сочинений, представленных на Московском Публичном театре , кн. 3). Здесь читаем: ААтеры очень часто не делают внимания к тем словам, которые говорят „про себя“. Они должны при сем так поступать, чтобы их совсем не слыхали те, от которых они утайкой произносят речь. Но они делают совсем напротив, говорят весьма громко, или очень близко тех, которые не должны их слышать, либо обращаются к публике. Последнее совсем не кстати; всегда предполагать должно, что публика будто не участвует в происходящем на театре (цит. по изд.: Всеволодский-Гернгросс, 1913, с. 194).

Вместе с тем, в пародийной пьесе Людвига Тика «Кот в сапогах $(1797$ г.) герои, напротив, снижают голос для того, чтобы публика их не подслушала (см.: Тынянов, 1977 , с. 302); и здесь также можно усмотреть реакцию на ту же условность театрального действия. 


\section{5 Взаимоотношение точек зрения на разных уровнях в произведении. Сложная точка зрения}

Предыдущее изложение было посвящено тому, к а к в о общ е м гут проя л я ть я точки зрения, т.е. позиции, с которых ведется повествование, в художественном произведении. Было показано, что они могут проявляться, в частности, в плане идеологической оценки (в плане «идеологии), в плане фразеологической характеристики (в плане «фразеологии»), В плане пространственно-временно́й перспективы (в «ростравственно-временно́м планея) и в плане субъективности/объективности описания (в плане «психологии ).

При этом естественно, что о бы ч н о та или иная точка зрения проявляется сразу во всех планах или, во всяком случае, одновременко в нескольких из них. Например, автор может вести повествование только от своего лица (случай Icherzählung), ви разу не принимая - ни в одном из упомянутых аспектов - какой-либо чужой точки зрения (между тем это отнюдь не непременное следствие из Icherzählung).

В других случаях автор может целиком и полностью - т.е. в самых разных отношениях - принимать точку зрения того или иного из своих героев. Это означает, во-первых, что автор регулярно описывает внутреннее состояние соответствующего героя, тогда как всех остальных персонажей дает с внешней стороны, через его восприятие, - и, таким образом, авторская позиция полностью совпадает с позицией данного героя в плане психологии; автор, далее, перемещается во времени и пространстве вместе со своим героем, он принимает его кругозор, - и, соответственно, позиция автора полностью совпадает с позицией данного персонажа в плане пространственно-временно́й характеристики; затем, при описании того, что видит и ощущает данный герой, автор может пользоваться его языком - в виде несобственно-прямой речи, внутреннего 
монолога или же в какой-то иной форме, - и тем самым псзиция автора совпадает с позицией данного персонажа в плане фразеологии; точно так же, наконец, позиция автора и позиция героя могут совпадать и в плане идеологической оценки.

Можно сказать тогда, что точки зрения, вычлевяемые ва различных уровнях анализа одного и того же произведения, совпадают между собой - и, соответственно, совпадают композиционные структуры этого произведения, устанавливаемые на разных уровнях; такой случай является тривиальным в плане использования композиционных возможностей.

Между тем подобное совпадение точек зрения, вычленяемых на. разных уровнях анализа, если и обычно, то, во всяком случае, отнюдь не обязательно. Проявление некоторой точки зрения в одном каком-то плане не предполагает с обязательностью проявления ее и в другом плане (на другом уровне анализа). Соответственно возможны сложные композиционные построения, когда на разных уровнях анализа вычленяются различные структуры одного и того же произведения. В принципе можно предполагать существование каких-то закономерностей, определяющих ту или иную связь различных структур художественного произведения, вычлевяемых на разных уровнях, т.е. то, насколько одна структура обусловлнвает другую и насколько они могут не совпадать. Пока, однако, мы не можем сказать чего-либо определенного о подобного рода закономерностях; мы ограничимся демонстрацией возможностей несовпадения точек зрения на разных уровнях анализа.

\section{Несовпаденке точек зрения, вычленяемых в пронзведеник на разных уровнях анализа}

Несовпадение ндеологической точки зрения с другими

Прежде всего точки зрения, проявляющиеся в произведении в плане идеологии, могут не совпадать с точками зрения, проявляющимися на других уровнях. 
Несовпадение шлана пдеологши в плана фрязеология

Несовпадение точек зрения в плане фразеологии и в плане идеологии имеет место прежде всего в том случае, когда повествование в произведении ведется с фразеологической точки зрения какого-то определенного лица, но композиционной задачей является оценка этого лица с какой-то другой точки зрения. Таким образом, в плане фразеологии данное лицо выступает как носитель авторской точки зрения, а в плане идеологии - как ее объект (как предмет авторской оценки).

Подобное несовпадение фразеологической и идеологической позиций характерно, например, для «сказа (ср., например, новеллы Зощенко). С другой стороны, этот прием можно считать вообе одним из типичных средств выражения и р о и и и.

Обратимся, например, к следующей фразе из авторской речи в -Братьях Карамазовых (эту фразу, между прочим, в несколько ином аспекте разбирает В.Н.Волошинов в его цитированной работе):

...Красоткин гордо отпарировал это обвинение, выставив на вид, что со сверстниками, с тринадцатилетними, д е й с т и те ль н о было бы позорно играть «в н a w в е в в лошадки, но что он делает это для 4I у з ы $\mathrm{p}$ е й॰, потому что их любит, а в чувствах его никто не с м е т у него спрашивать ответа (Достоевский, т. XIV, с. 467).

Здесь выделены наиболее очевидные случаи авторского использования чужой речи; они со всей определенностью указывают на то, что в данном случае используется точка зрения Коли Красоткина - точка зрения, проявляющаяся в плане фразеологии; но в то же время на ней лежит печать авторского отношения (иронии) и, таким образом, эта точка зрения входит как составной элемент в какую-то иную (более общую) авторскую точку зрения. Автор ассоциируется с Красоткиным фразеологически, но не идеологически: он говорит в данном случае от его лица (т.е. используя в авторской речи его фразеологию), но со своей собственной позиции: в плане идеологии Красоткин выступает не как носитель авторской точки зрения, но, напротив, как объект авторской оценки. Итак, если в плане фразеологич автор принимает точку зрения персонажа, то в плане идеологии он сотраняется от него. 
Подобного рода несовпадение точек зрения - авторское остранение в плане общей идеологической оценки, сочетающееся с принятием точки зрения в каком-то ином плане (фразеологии, психологии и т.п.), - является принципиально важным для создания эффекта иронии. Этот эффект возникает в такой ситуации, когда мы говорим с какой-то одной точки зрения, а производим оценку - с совершенно другой; таким образом, несовпадение точек зрения на разных уровнях тут обязательно ${ }^{1}$.

Разбирая случаи использования чужой речи в повести Достоевского ^Скверный анекдот , В.Н.Волошинов приходит ж выводу, что -Почти каждое слово этого рассказа с точки зрения своей экспрессии, своего эмоционального тона, своего акцентного положения во фразе входит одновременно в два пересекающиеся контекста, в две речи: в речь автора-рассказчика (ироническую, издевательскую) и в речь героя (которому не до иронии) 2. Таким образом, и здесь налицо несовпадение идеологической и фразеологической точек зрения; при этом существенно, разумеется, что фразеологическая точка зрения подчинена идеологической.

Сама возможность двойственного использования чужой речи - в плане фразеологической точки зрения и в плане идеологической точки зрения - заложена уже в двойственном характере явления несобственно-прямой речи. Несобственно-прямая речь, как отмечает В.Н.Волошинов, есть р ч ч в р е и и вместе р е ч о р е ч и: -Чужое высказывание может восприниматься как определенная смысловая позиция говорящего, и в этом случае с помощью косвенной конструкции аналитически передается его точный предметный состав... Но можно воспринять и аналитически передать чужое высказывание как выражение, характеризующее не только предмет речи (или даже не столько предмет речи), но и самого говорящего ${ }^{3}$.

Несовпаденяе плана цдеалогин n плана псиxororia

При рассмотрении плана психологии мы отмечали, что число действующих лиц, описание которых производится «инутри», а

\footnotetext{
1 Подробнее об иронии см. ниже (глава шестая).

2 Волошинов, 1929 , с. 161.

3 Там же, с. 152.
} 
не «звне॰, - иначе говоря, число персонажей, с психологической точки зрения которых может строиться повествование в данном произведении, - нередко бывает ограничено в произведении. Можно сказать, что в образы одних персонажей автор может на время « вживаться•, описывая мир через их восприятие, тогда как другие интересукт его пренмущественно в плане восприятия со стороны.

Для характеристики произведения весьма существенно, насколько соотносится раскрытие или нераскрытие внутреннего состояния того или иного персонажа с отношением к нему автора в плане идеологической оценки. Иначе говоря, вопрос ставится так: насколько соотносится В двнном произведении принцип ввнутреннего и «непнего описания с рвзделением персонвжей нв *положительные и «отрицательные .

Естественно думать, в самом деле, что в ряде случвев описание персонажа «ивне или «изнутри определяется именно отношением автора к нему, т.е. точку зрения одних персонажей автор в принципе может принять, тогда как психологическая позиция других ему внутренне чужда или даже непонятна; соответственно автор не может отождествить (пусть даже и на время) их точку зрения со своей - персонвжи такого рода даются исключительно в плане внешнего описания, их внутреннее состояние не описывается. (Авторв здесь уместно было бы сравнить с актером, который может перевоплотиться не во всякую роль, но только в такую, которую он может как-то ассоциировать со своим «

Можно сказать, что позиция автора в этом случве в принципе не отличается от позиции читателя: автор становится на точку зрения только такого героя, с которым может (по ввторскому замыслу) ассоциировать себя читатель ${ }^{4}$.

Таким образом, в этом случае разделение персонажей по принципу их описания в плане психологии (*извне и *изнутри ) совпадает с разделением персонажей на положительных и отрицательных - и, следовательно, имеет место совпадение психологической и идеологической точек зрения (в большой степени это характерно, например, для Толстого ${ }^{5}$ ).

Подобное совпадение, однако, отнюдь не обнзательно: во многих случаях подразделение персонажей на положительных и отри-

4 О возможностях различия между авторской и читательской позициями см. подробнее ниже (глава шестая).

5 По словам Шкловского, єотрицательные герои [у Толстого - Б.У.] только поступают, но не думают (см.: Шкловский, 1927, с. 21). 
цательных и на описанных с внешней и внутренней точек зрения - не совпадают, но пересекаются, т.е. автор в равной мере может описывать внутреннее состояние как положительного, так и отрицательного персонажа (например, в “Братьях Карамазовых Достоевского нередко дается описание переживаний Федора Павловича Карвмазова).

Соответственно можно сказать, что позиция автора и позиция читателя различаются в этом случае: автор может принимать точку зрения, которую читателю должно быть по идее трудно ассоциировать со своей.

\title{
Несовпадение
} пространственно-временно́й точки зрения с другими

Совершенно так же иногда мы можем наблюдать несовпадение точки зрения, проявляющейся в плане пространственно-временно́й перспективы, и точки зрения, проявляющейся в каком-то ином плане. Наиболее характерным является здесь несовпадение точек зрения, проявляющихся в плане пространственно-временно́й характеристики и в плане психологии.

\author{
Несовпадение \\ пространственпі- \\ временио́й \\ и психологнческой \\ Touek зрения
}

Подобного рода несовпадение может проявляться, например, в том, что носитель пространственно-временно́й точки зрения (т.е. то лицо, чьим кругозором пользуется автор) показывается не изнутри*, а иизве*, т.е. через восприятие какого-то другого наблюдателя. (Напротив, носитель психологической точки зрения, т.е. лицо, чье восприятие использует автор в своем описании, может попасть в этом случае в пространственный кругозор какого-то иного лица.)

Примером здесь может служить хотн бы та сцена из ВВойны и мира», когда - в день именин обеих Наталий (старой графини и Наташи) - графиня Ростова, желая поговорить с глазу на глаз с Анной Михайловной Друбецкой, просит Веру пойти к себе (Тол- 
стой, т. IX, с. 55-56). Вера поднимается и идет в свою комнату; и далее на некоторое время автор (а вместе с ним и читатель) ставовится ее спутником. Когда Вера проходит мимо диванвой, описывается сцена с детьми - постольку, поскольку они попали в ее кругозор. Таким образом, ва какой-то отрезок времеви мы видим мир в ее перспективе, но перспективе исключительно пространственной, а не психологической или какой-либо другой. Автор становится спутником Веры, но он ви на миг не перевоплощается в нее самое (как ов это часто делает в других местах по отношению к другим действующим лицам): каждый раз, когда на протяжении этого отрывка речь заходит об ощущениях самой Веры, автор считает нужным прибавить слова остранения "видимо , чочевидно и т.д. Таким образом, сама Вера дается с точки зрения постороннего наблюдателя (так же как и те, кого она видит); автор как бы находится все время рядом с ней, но при этом не пользуется ее восприятием. Аналогичным образом описывается в Войне и мире попытка Анатоля Курагина похитить Наташу (т. X, с. 351 и далее): на протяжении всего описания автор следует за Анатолем в его пространственных перемещениях, но не принимает его точки зрения в плане психологии.

Другой случай подобного несовпадения можно представить на примере описания Ставрогина во второй части •Бесов Достоевского (главы I и II: „Ночь - см. т. X, с. 166 и далее). Ставрогин вообще дается обычно со стороны, его образ в большой степени представлен автором как загадка ${ }^{6}$, разгадать которую мы становимся отчасти способны лишь $k$ концу всего повествования. Соответственно и выражения, описывающие внутреннее состояние, относятся к Ставрогину более или менее редко.

В рассматриваемом отрывке, описывающем ночное путешествие Ставрогина по городу, герой почти исключительно дается со стороны, глазами стороннего наблюдателя. Эта отчужденность описания постоянно подчеркивается автором: автор все время говорит о выражении лица Ставрогина и вообще о в н е ш н и х признаках поведения, но почти не говорит о его мыслях и чувствах ${ }^{7}$.

Вместе с тем этот незримый посторонний наблюдатель, с точки зрения которого производится описание Ставрогина (в том числе и в тех случаях, когда тот совершенно один), как бы все время

6 См. в әтой связи выше (с. $120-123$ ).

${ }^{7}$ Немногими исключениями здесь можно как будто бы пренебречь. 
находится со своим героем - авторский объектив движется вместе со Ставрогиным, не перевоплощаясь в него. Мы следуем за СтавроГиным во всем его длинном ночном путешествии и видим то, что он должен был видеть. Например, комната, в которую входит Ставрогин, улица, по которой он идет, описываются такими, какими они ему должны были представиться, - а на самом же деле такими, какими их увидел посторонний наблюдатель, воспользовавшийся его перспективой. Ср. описание комнаты капитана Лебядкина:

Николай Всеволодович осмотрелся; комна̇та была крошечная, низенькая; мебель самая необходимая, стулья и диван деревянные, тоже совсем новой поделки, без обивки и без подушек, два липовые столика, один у дивана, a другой в углу, накрытый скатертью, чем-то весь заставленный и прикрытый сверху чистейшею салфеткой. Да и вся комната содержалась, по-видимому, в большой чистоте. Капитан Лебядкин дней уже восемь не был пьян; лицо его как-то отекло и пожелтело, взгляд был беспокойный, любопытный и, очевидно, недоумевающий: слишком звметно было, что он еще сам не знает, каким тоном ему можно заговорить... (т. X, с. 207).

Вряд ли эта детальная картина передана глазами Ставрогина, это описание дается, скорее, п п по в д у того, что Ставрогин осмотрел комнату, но едва ли является ре з у л т а том его впечатления от ее осмотра ${ }^{8}$.

Таким образом, здесь можно было бы говорить не о т о ч к е з р е и я, а о п о л $е$ р е н и Ставрогина. Сам же Ставрогин выступает скорее в функции предмета рассмотрения, чем в качестве аппарата ви́дения.

Особенно показательно, что на протяжении данных глав Ставрогин попадает в сферу восприятия разных лиц - своей матери Варвары Петровны (т. X, с. 182), капитана Лебядкина (т. X, с. 209-214) - и описывается при этом их глазами. Он попадает, таким образом, в различные психологические точки зрения, но пространственно-временна́я точка зрения здесь принадлежит ему одному.

${ }^{8} \mathrm{Cp}$. еще аналогичный пример в кн.: Шкловский, 1928, с. 197: Шкловский констатирует, что описание военного совета в Филях в «Вйне и мире дано с точки зрения крестьянской девочки Малаши, но при этом отмечаются такие подробности, которые не мог фиксировать ребенок. 

Несовпадевие пространственио- временно́й
и фразеологтческой точек зрения

Этот случай можно иллюстрировать хотя бы при помощи того отрывка из «Войны и мира", где говорится об отношениях Николая Ростова с Долоховым (т. Х, с. 42 и далее). Здесь используется пространственно-временна́я (а отчасти и психологическая) точка зрения Николая, которая однажды сочетается с точкой зрения матери Долохова, проявляющейся в ином плане - в плане фразеологии: ‘Старушка Марья Ивановна, полюбившая Ростова за его дружбу к $\Phi$ е д е, часто говорила ему про своего сына (т. $X$, с. 42). Обозначение -Федя: со всей определенностью указывает здесь на фразеологическую точку зрения самой Марьи Ивановны (ср. это же обозначение в ее прямой речи несколько ниже в тексте романа).

\section{Совмещение точек зрения на одном и том же уровне}

Итак, различные точки зрения, вычленяемые на разных уровнях при анализе произведения, не обязательно должны совпадать; соответственно композиция такого произведения характеризуется совмещением нескольких различных композиционных структур. В результате имеет место сложная (совмещенная) композиционная структура (для графического изображения которой может .требоваться многомерное пространство), когда повествование в целом ведется с одновременным использованием нескольких точек зрения, которые находятся в различных между собой отношениях. При этом точки зрения, используемые при повествовании, могут вступать друг с другом как в синтагматические, так и в парадигматические отношения.

В других случаях подобное совмещение различных точек зрения имеет место не на разных уровнях произведения, а на одном и том же уровне. Иначе говоря, повествование производится сразу с двух (или более) различных позиций - что можно сравнить с эффектом двойного света в живописи, т.е. с использованием сразу 
двух источников освещения. (Этот прием нередок, например, у средневековых мастеров, у Рубенса и т.д. ${ }^{9}$ )

При этом речь идет не о смене авторской позиции, т.е. не о переходе от одной точки эрения $к$ другой в процессе повествования (этот случай уже неоднократно нами рассматривался), но именно о с о в м е щ е н и и точек зрения, т.е. об одновременном использовании при повествовании нескольких различных позиций - что можно рассматривать как результат наложения друг на друга нескольких несовпадаюших между собой композиционных структур (вычленяемых при этом на одном и том же уровне внализа) ${ }^{10}$.

Наиболее характерным является случай, когда одной из совмещаемых точек зрения выступает специальная точка зрения некоторого р а с с к а з ч и к а, явно или неявно присутствующая в повествовании. Эта точка зрения может склеиваться при повествовании с точкой зрения какого-либо персонажа, а иногда даже и с точкой зрения какого-то другого рассказчика. Таким образом, речь идет о совмещении (постоянном или эпизодическом) позиции рассказчика с какой-либо другой позицией при построении повествования.

Примером здесь могут служить произведения Толстого, в частности его «Война и мир».

Совмепение позичин рассказчиса с какой-либо друтой при повестования - •Boйне и мирен

Повествование в «Войне и мире может вестись одновременно по меньшей мере с двух позиций (несколько ниже мы увидим, что

${ }^{9}$ Cp.: Жегин, 1970, табл. XXII.

$10 \mathrm{Cp.} \mathrm{осознанное} \mathrm{представление} \mathrm{такого} \mathrm{приема} \mathrm{описания} \mathrm{у} \mathrm{Андрея} \mathrm{Белого.}$ Анализируя (post factum) описание болезни ребенка в своей повести * Котик Летаев - - имеющее автобиографический характер, - Белый пишет: ‘...автор зарисовывает интересный случай проблесков сознания, складывающихся в сорокаградусном жару, в момент кори; далее отчетливый момент сознания между корьи и скарлатиной; далее - скарлатинный жар: и после него первый взгляд на детскую комнатку уже в условиях нормальной температуры (выздоровление). Но, взя в принии пе точку зрения младенца, не ведаюшего, что онболен и что переживае моеиместьжар, автор пытается средствами сознания варослого передать особенности жарового состояни я м а денц а так, как память ему доносит о них... (см.: Белый, 1931. г. 1є2). 
в известных случаях их можно насчитать и больше) - с точки зрения коғо-то из героев произведения (Наташи, князя Андрея, Пьера и т.д.) и вместе с тем с точки зрения какого-то наблюдателя (рассказчика), который может неявно присутствовать на месте действия. Наблюдатель этот (который, по-видимому, достаточно близок к самому автору, но не обязательно должен с ним отождествляться) выступает в позиции человека, очень хорошо знающего тех, о ком идет речь, их предысторию, а часто даже и мотивы их поступков; таким образом, ему может быть известно и то, что порой скрыто от самосознания самих действующих лиц (можно сказать, что ему открыто не только их сознание, но и их подсознание). Но при этом, по-видимому, в этой роли выступает не всевидящий наблюдатель, обладающий даром абсолютного проникновения, но просто очень проницательный и умный11 человек - рассказчик - со своими симпатиями и антипатиями, со своим человеческим опытом и, наконец, со свойственной всякому человеку (но не обязательно авторуl) огр а н и ен н о стью з н н и я. Ср., например, следующий характерный отрывок из «Войны и мира - с описанием Анатоля Курагина, - где достаточно ясно обрисована психологическая позиция рассказчика.

Анатоль молчал, покачивал ногой, весело наблюдая прическу княжны. В и д н о бы ло, что он так спокойо мог молчать очень долго. Ежели кому неловко это молчание, так разговаривайте, а мне не хочется», к а к буд то говори л его ви д. Кроме того, в обращении с женщинами .у Анатоля была та манера, которая более всего внушает в женщинах любопытство, страх и даже любовь, - манера презрительного сознания своего превосходства. К а к будто он Говорил и м своим еидом: Знаю вас, знаю, да что с вами возиться? А уж вы бы рады: $\mathrm{M}$ о жет бы ть, что он этого не думал, встречаясь с женщинами (и даже вероятно, что нет, потому что он вообще мало думал), но такой $\mathrm{y}$ него был вид и такая манера (т. IX, c. $271-272$ ).

11 Последнее, между прочим, отнюдь не обязательно для рассказчика. Если у Толстого рассказчик обычно умнее (или, уж во всяком случае, не глупее) своих героев, то не так у Достоевского, где рассказчик часто занимает сниженную (усредненную) позицию: тем самым герои Достоевского могут быть проницательнее и тоньше своего рассказчика. 
С одной стороны, рассказчик находится здесь в позиции постороннего наблюдателя, который не может знать наверное, что думал и чувствовал Анатоль, но может строить предположения на этот счет (в этом отношении показательны выражения остранения, выделенные нами в тексте). С другой стороны, этот рассказчик, не зная наверное о переживаниях Анатоля в данный момент, в принципе достаточно хорошо знает Анатоля - как может знать его, например, близко с ним знакомый человек (об этом свидетельствуют ссылки на его поведение с женщинами, на то, что он вообще мало думал, и т.п.). Наконец, рассказчик этот обладает и собственным личным опытом (он сообщает нам, например, - со своей собственной точки зрения, а не с точки зрения Анатоля - о том, что́ внушает женщинам любопытство, любовь или страх), ведя таким образом повествование не с какой-то абстрактной и безличной, но с достаточно конкретной человеческой позиции.

При этом иногда рассказчик отступает куда-то в сторону, пропадает, и повествование ведется исключительно с точки зрения кого-то из действующих лиц - как будто бы рассказчика и нет вовсе. Так дается, например, история разрыва Пьера и Элен. Начиная с обеда в честь Багратиона в Английском клубе, описание ведется здесь большею частью исключительно с точки зрения Пьера, которая часто переходит даже в его внутренний монолог (см., например, т. X, с. 21 и далее). Лишь эпизодически описание это (т.е. описание с точки зрения Пьера) перебивается описанием с точки зрения кого-то еще (например, Николая Ростова, недоброжелательно и насмешливо смотрящего на Пьера) или же нобъективным* описанием поступков самого Пьера с точки зрения какого-то внешнего наблюдения. При этом проницательный и знающий рассказчик здесь отсутствует: очень показательно, что мы знаем об измене Элен с Долоховым ровно столько же, сколько об этом знает сам Пьер. Мы можем лишь догадываться - вместе с Пьером - об этой измене, но мы, по существу, так до конца ничего не знвем об этом достоверно (так же, как и Пьер, мы знаем лишь о внешних признаках дела - таких, как анонимное письмо, вызывающее поведение Долохова и т.д.). Таким образом, рассказчик, столь много знающий в других случаях, как бы отступает здесь за кулисы, целиком предоставляя читателю пользоваться восприятием Пьера.

Вообще могут быть два типа рассказчика - независимо от того, дан ли рассказчик в произведении явно (как в •Братьях Карамазо- 
вых ) или неявно (как в *Войне и мире $)^{12}$. Рассказчик одного типа более или менее постоянно участвует в действни; если при этом используется чья-то еще точка зрения, то возникает сложная композидиондая структура с совмещением точек зрения. Рассказчик другого типа, напротив, может исчезать; соответственно описание в әтом случае может производиться с точек зрения различных лиц, в том числе и с точки зрения рассказчика; таким образом, рассказчик в последнем случае выступает, в общем, в той же функции, что и тот или иной персонаж данного произведения.

В других же случаях - обыкновенно в начале какого-то нового повествования ${ }^{13}$ - рассказ в Войне и мире определенно не ведется с точки зрения, принадлежащей кому-либо из действующих лиц. Но повествование от этого не становится безличным описанием, беспристрастно регистрирующим какие-то объективные факты поведения персонажей: мы можем узнать из такого описания и о субъективных переживаниях последних и даже о мотивах их поведения (которые могут быть скрыты, между тем, от них самих); мы узнаем далее и о том, как вы г л д е л о их поведение - с очевидной ссылкой ка восприятие какото-то субъекта (не ассоциируюпегося, однако, ни с кем из лиц, принимающих участие в действии).

Итак, рассквзчик в «Войне и мире дан в этом отношении так же, как и его герои (возможные носители авторской точки зрения): и здесь и там происходит ссылка на чъе-то субъективное восприятие.

Любопытно в этой связи, что восприятие рассказчика может даже расходитъся с восприятием героев - точно так же, как могут расходиться, например, впечатления двух разных людей, воспринимающих какое-то событие. В этой связи интересен, в частности, эпизод с описанием казни Верещагина. Сама сцена казни дается Толстым с некоторой отчужденной позиции: автор не прибегает здесь ни к точке зрения графа Растопчина, которую он использовал еще совсем недавно (см.: т. XI, с. 345 ), ни к точке зрения ка-

12 В первом случае он может вести повествование от своего (первого) лица, во втором же случае он должен быть выявлен в результате специального анализа.

13 Что, конечно, связано с функцией «рамки॰, см. подробнее ниже, глава седьмая. 
кого-либо другого из персонажей ${ }^{14}$; можно сказать, что здесь используется точка зрения откровенно субъективная ${ }^{15}$.

Далее автор описывает, как граф Растопчин после казни едет по оставленной жителями Москве - причем в этом описании используется уже точка зрения (психологическая) - самого Растопчина, т.е. подробно описываются его переживания. Терзаемый раскаянием, Растопчин вспоминает подробности только что происшедшего. «Он слышал, е м к к з а л о с ь те п е р в, звуки своих слов „Руби его, вы головой ответите мне!“ (т. XI, с. 352).

Но замечательно, что он н е го во р и л именно этих слов, которые звучат теперь в его сознании!

Нам подробно описывалась - с точки зрения рассказчика сцена казни, нам передавалось каждое слово Растопчина, и эти слова там не произносились (хотя и произносились другие, близкие по смыслу) - во всяком случае, они не были зафиксированы в восприятии рассказчика.

Таким образом, восприятие рассказчика и восприятие персонажа расходятся в данном случае, и это характерное свидетельство субъективности как того, так и другого.

Итак, мы вправе говорить о наличии специального p a c с к а з и к а в “Войне и мире», причем рассказчик этот не дан явно - в том смысле, что не ведет (как правило) повествование от своего лица (ср., с другой стороны, “Братья Карамазовы Достоевского или «Вечера на хуторе близ Диканьки" Гоголя, где рассказчик присутствует в повествовании совершенно явно, хотя и не принимает участия в действии: время от времени он ведет повест-

14 Действительно, каждый раз, когда говорится про ощущения кого-либо из действующих лиц в этой сцене, автор считвет нужным употреблять «слова остранения - операторы, переводящие действие в план внешнего описания (см. о них выше, с. 113-114). Ср., например, о Растопчине: „Растопчин ...orлянулся... К а к б ы отыскивая кого-то (т. ХI, с. 346); "А!“ - вскрикнул Растопчин, к а к пораженный каким-то неожиданным воспоминанием (там же). O Верещагине: •Он посмотрел на толпу и, к а к бы обнадеженный тем выражением, которое он прочел на лицах людей... (т. XI, с. 347).

15 Субъективность авторского описания видна, например, в следующих фразах: «Граф! - проговорил ...робкий и вместе те а т ральны й гол о с Верещагина (т. XI, с. 348); "A!“- коротко и у д и в ле н н о вскрикнул Верещагин, испуганно оглядываясь и как будто не пон и м а я, зачем это было с ним сделано (там же), и т.п. Автор описывает эту сцену, в общем, так же, как мог бы ее описать кто-либо из его героев. 
вование от своего, т.е. первого, лица, но может и отступать, и в этом случве автор целиком переключается на восприятие того или иного героя).

Более того, внимательное рассмотрение позволяет выявить в *Войне и мире не одну, а по крайней мере две позиции рассказчика - или, если угодно, двух различных рассказчиков 16 .

Одним рассказчиком является тот проницательный наблюдатель, о котором мы говорили выше; ов хоропо знаком с людьми, о которых пишет, ему дано знать их прошлое (но, между прочим, не их будущее ${ }^{17}$ ); он может анализировать их действия как в свете их сознания, так и в плане их подсознательных побуждений, он имеет и собственную концепцию жизни, истории и т.П. (ибо нет как будто достаточных оснований считать этого рассказчика и автора отступлений в *Войне и мире разными лицами).

Существенно, что вопрос об источниках знания о персонажах у данного рассказчика вообще неправомерен, т.е. неправомерно задаваться вопросом, откуда ему известны факты, относящиеся к сознанию и подсознанию действуюцих лиц. На этот вопрос, если его все-таки поставить, могло бы быть отвечено, вообще говоря, с очевидным выходом за пределы обсуждаемой проблематики, что эти факты ему известны, потому что он создал своих героев. (Такой ответ, понятно, может показаться некорректным, но наша задача здесь - подчеркнуть, что некорректен и сам вопрос.) Иначе говоря, позиция такого рассказчика - это отнюдь не позиция непосредственного наблюдателя, но позиция п о в с т в в а т е л я в о о 6 щ е. Он отчужден от своих героев, занимая принципиально иную - более общую - позицию, нежели персонажи произведения.

Между тем в повествовании *Войны и мира явно определяется еще одна позищия рассказчика; ее можно было бы определить как позицию н е п о ре д с те н ного на блю да те л который незримо присутствует в описываемой сцене и как бы ведет синхронный репортаж с самого поля действия. Тем самым, рассказчик здесь поставлен в те же условия, что и действующие лица в произведении; соответственно к нему применяются те же

16 Ср. выделение нескольких рассказчиков в произведениях Гоголя - Гуковский, 1959, с. 46-48, 51, 52, 206, 222.

17 Мы уже говорили, что при определенной временно́й позиции рассказчик может намекать не только на свое знание прошлого, но и на знание будущего, т.е. того, что только еще должно произойти (см. выше, с. 93-94). 
ограничения в знаниях, которыми характеризуются действующие лица.

Таким образом, во временно́м плане позицию этого последнего рассказчика можно определить как синхронную, тогда как позиция первого - панхронистична. Вообще, если пространственновременна́я позиция второго рассказчика непосредственно связана с местом и временем описываемого события, то первый рассказчик занимает более общую и широкую позицию.

В более общих терминах можно сказать, что второй рассказчик ведет описание и з у т р и описываемого действия, тогда как первый рассказчик занимает в н ш н ю ю по отношению к описываемому действию позицию. О типологических аналогиях с живописью будет сказано ниже (см. главу седьмую).

Обе упомянутые позиции рассказчика проявляются с первой же сцены «Войны и мира — с вечера у Анны Павловны Шерер, которым открывается роман. Описание вечера не дается, восбще говоря, с чьей-либо специальной точки зрения ${ }^{18}$.

При этом очень часто здесь употребляются слова и выражения остранения (типа «видимо и т.п.), указывающие на присутствие какого-то синхронного наблюдателя (который может совпадать либо не совпадать с кем-то из участников действия).

Например:

...сказал он [князь Василий. силах удерживать печальный ход своих мыслей (T. IX, c. 8).

Но среди этих забот в с е в и д е б б л в ней [Анне Павловне. - Б.У.] особенный страх за Пьера (т. IX, c. 12).

Автор, конечно, здесь мог бы и просто сказать, что князь Василий был не в силах сдержать печального хода мыслей (говоря об Анатоле) и что Анна Павловна боялась за Пьера. Однако автор явно ощущает необходимость (и это очень показательно) сослаться на чье-то впечатление - он как бы не считает себя вправе утверждать, что данные мысли де й с тв и те льно имели место;

18 За отдельными исключениями. Так, в одном месте как будто бы проскальзывает точка зрения Анны Павловны (т. IX, с. 16), в другом месте точка зрения Пьера (т. IX, с. 12) - но, впрочем, и эти места могут быть в равной степени отнесены к всезнающему повествователю. 
ссылка на действительность при том подходе, который здегь имеет место, по-видимому, вообще неправомерна.

Характерно, что автор прибегает к такому же способу описания даже тогда, когда о ш у ш е и е описываемого лица не вызывает никакого сомнения:

Ему [князю Андрею. - $\boldsymbol{Б} . \boldsymbol{Y}]$, в и д и м о, все.бывшие в гостиной не только были знакомы, но уже надоели ему так, что и смотреть на них и слушать их ему было очень скучно (т. IX, с. 17).

Все последующее изложение убеждает нас в том, что это не только видимость, но и действительно так и есть; знакомство с князем Андреем (на которое претендует автор в других случаях), казалось бы, должно было дать ему достаточно оснований не сомневаться, что это так. Тем не менее автор считает нужным говорить эти очевидные вещи со ссылкой на чье-то впечатление.

Чье же это впечатление? Быть может, кого-то из действующих лиц, участвующих в сцене? Так, действительно, можно было бы думать, но вот другая фраза - из разговора Анны Павловны с князем Василием:

- Avant tout dites-moi, comment vous allez, chère amie? ${ }^{\star} \mathrm{Ycno}^{-}$ койте меня, - сказал он, не изменяя голоса и тоном, в котором из-за приличия и участия п р о с веч и в а ло ра вноду ди и и даже насмешка (T. IX, c. 4).

Здесь речь идет опять-таки о чьем-то субъективном впечатлении, но это, конечно же, не может быть впечатление Анны Павловны; между тем, кроме них двоих, в гостиной никого нет. Следовательно, это впечатлевие некоего наблюдателя, незримо присутствующего на месте действия.

В то же время иногда автор становится на позицию рассказчика, не только описываљщего своих героев в данный момент, но и прекрасно знающего их вообще, т.е. на такую позицию, которую выше мы охарактеризовали как позиция всезнающего повествователя. Ср., например, характеристику Анны Павловны Шерер. в том же отрывке из «Войны и мира»:

\footnotetext{
` Прежде всего скажите, как ваше здоровье, милый друг?
} 
Быть энтузиасткой сделалось ее общественным положением, и иногда, когда ей даже того не хотелось, она, чтобы не обмануть ожиданий лкдей, знавших ее, делалась энтузиасткой (т. IX, с. 5).

Это не точка зрения самой Анны Павловны (которая едва ли сама о себе так думает) и навряд ли точка зрения кого-то из ее собеседников; это точка зрения рассказчика, причем, как мы увидим, рассказчика, занимающего принципиально иную позицию, нежели позиция непосредственного наблюдателя.

Или еще (о князе Василии):

- ...Скажите, - прибавил он, как будто только что вспомнив что́-то и особенно небрежно, тогда как то, о чем он спрашивал, было главною целью его посещения, правда, что l'imperatrice-mère желает назначения барона Функе первым секретарем в Beну? (т. IX, с. 6).

Автору здесь ведомо то, что может знать только сам князь Василий, но при этом описание производится не с точки зрения князя Василия, а с точки зрения какого-то внешнего по отношению $к$ нему наблюдателя; здесь опять-таки выступает позиция рассказчика, досконально знающего своих героев (не только описывающего их в некоторый данный момент, но все вообще про них знаюего).

Можно было бы думать, что различение двух рассказчиков в •Войне и мире искусственно, т.е. что в обоих случаях выступает один и тот же рассказчик, который, вообще говоря, достаточно хорошо знает своих героев, но может выступать при этом в качестве репортера, ведущего синхронный репортаж непосредственно с места действия; и действительно, в большинстве случаев принадлежащие рассказчику фразы могут трактоваться таким образом. Но с этой точки зрения особенно интерескы такие фразы, принадлежащие рассказчику, которые не могут быть объединены в одну авторскую позицию.

Ср., например (все из того же отрывка):

...сказала ... Анна Михайловна с улыбкой молодой кокетки, которая когда-то, д о л н о 6 ы т ь, была ей свойственна, а теперь так не шла $к$ ее,истощенному лицу (т. IX, c. 21).

Это «должно быть", это огравичение авторского знания о персонаже со всей определенностью указывает на то, что описание в дан- 
ном случае принадлежит непосредственному наблюдателю (незри-мому участнику действия). Оно никак не вяжется с тем неограниченным знанием о персонаже, которое обнаруживается в характеристиках, приведенных выше.

Или:

...при виде вошедшего Пьера в лице Анны Павловны изобразилось беспокойство и страх, подобный тому, который выражается при виде чего-нибудь слишком огромного и несвойственного месту (т. IX, с. 11).

Автор не говорит здесь о том, что н а с а м о м д е л е испытала Анна Павловна; автор просто стоит перед задачей как-то передать выражение ее лица, причем делает это, ссылаясь на выражение лица, обычное в определенной ситуации. Таким образом, автор выступает здесь отнюдь не как всевидящий наблюдатель, но как живое лицо с некоторым реальным опытом.

Эта характерная ограниченность знания, свойственная именно непосредственному (синхронному) наблюдателю, наглядно прослеживается в таких фразах (достаточно характерных для Толстого), как, например, следующая: «...сказал князь, взяв вдруг свою собеседницу за руку и пригибая ее п о ч м у - т о книзу (т. IX, с. 9).

Ср. также специальные подчеркивания ограниченности авторского знания в «ойне и мире»:

Маленькая княгиня н е с лы х а л а и ли н е хотел а слыш ат в его слов (т. IX, с. 125).

Лицо князя Андрея было очень задумчиво и нежно... Страшно ли ему было идти на войну, грустно ли бросить жену, - м о е т б ы т ь, и то и другое, только, видимо, не желая, чтоб его видели в таком положении, услыхав шаги в сенях, он... принял свое всегдашнее, спокойное и непроницаемое выражение (т. IX, с. 128).

От неловкости или умышленно (н и к т о 6 ы н е мог разобрат т э того) он [князь Ипполит. Б.У.] долго не опускал рук... (т. IX, с. 28$)$.

Две позиции повествователя в Войне и мире тем самым, суть две разные позиции, хотя они и могут с к л и в а т в с вместе при повествовании. Точно так же каждая из этих позиций может совмещаться с позицией того или иного персонажа. Во всех этих 
случаях и образуется совмещенная точка зрения; при этом надо подчеркнуть, что это совмещение происходит на одном и том же уровне.

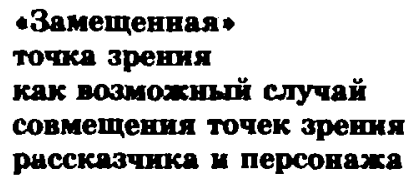

Если мы обратимся к только что приведенному примеру, описывающему чувства Анны Павловны Шерер при виде вошедшего в ее салон Пьера Безухова, мы увидим, что рассказчик в данном случае как бы подменяет точку зрения (психологическую) Анны Павловны своей точкой зрения. Он говорит не столько о том, что о щ у щ а л а Анна Павловна, сколько о том, что она д о л н а 6 ы а 6 ы о у а т ь. Иначе говоря, рассказчик, интерпретируя выражение лица Анны Павловны, как бы воспринимает за нее самое (вкладывая в ее душу собственные ощущения, которые он - рассказчик - имел бы на ее месте), - причем эта интерпретация может быть достаточно правдоподобна, т.е. очень вероятно, что эти ощущения соответствуют действительным ощущениям самого персонажа (Анны Павловны).

Этот прием вообще характерен для Толстого. Например, еще:

Присутствие Наташи, женщины, барыни верхом, довело любопытство дворовых дядюшки до тех пределов, что многие, не стесняясь ее присутствием, подходили к ней, заглядывали ей в глаза и при ней делали о ней свои замечания, как о показываемом чуде, которое не человек, и не может слышать и понимать, что́ говорят о нем (т. X, c. 262).

Здесь психология персонажей сливается с психологическим объяснением рассказчика, интерпретирующего их позиции.

Соответственно можно считать, что в подобных случаях имеет место совмещение двух психологических точек зрения - точки зрения персонажа и точки зрения рассказчика, интерпретирующего ощущение этого персонажа путем подстановки собственных ощущений в данной ситуации.

Этот же процесс часто имеет место и в тех случаях, когда при описании внутреннего состояния персонажа автором используются 
слова типа "видимо", «как будто" и т.п. Подобные слова вообще (как это уже отмечалось выше) свидетельствуют об о с т р а н е н и и авторской позиции, т.е. о точке зрения постороннего наблюдателя. Эта остраненная точка зрения может относиться прежде всего к рассказчику, но при этом она может (более или менее спорадически) совпадать с точкой зрения того или иного действующего лица.

В этом плане характерен следующий отрывок из сцены охоты в Отрадном из «Войны и мира (описывающий соревнование охотников и победу дядюшки на этом соревновании):

Дядюшка сам второчил русака, ловко и бойко перекинул его через зад лошади, как бы упрекая всех этим перекидыванием, и с таким видом, что он и говорить ни с кем не хочет, сел на своего каураго и поехал прочь. Все, кроме его, грустные и оскорбленные, разъехались и только долго после могли притти в прежнее притворство равнодушия (т. X, с. 262).

Здесь очевидно авторское остранение, т.е. присутствие рассказчика, интерпретирующего ситуацию со своей (откровенно остраненной) точки зрения и в известной степени звмещающего переживания персонажей своею интерпретацией. Действительно, реальных поводов для подобного рода ощущений вроде бы нет - рвссказчик просто интерпретирует внешнее поведение действующих лиц, пытаясь передать как будто бы не столько действительные их переживания, сколько то, как их поведение могло быть воспринято посторонним наблюдателем.

Любопытно, однако, что абзвцем ниже мы узняем, что точка зрения рассказчика совпадает с точкой зрения Николая Ростова.

Когда, долго после, дядюшка подъехал к Николаю и заговорил с ним, Николай был польщен тем, что дядюшка после всего, что́ было, еще удостоивает говорить с ним (т. X, c. 262).

Здесь можно говорить о своего рода В о з д е й с т в и и, которое оказывает точка зрения рассказчика на точку зрения персонажа (как бы притягивая ее $к$ себе), а в конечном счете - о специальном случае совмещения точки зрения рассказчика и точки зрения действующего лица.

Таков возможный процесс совмещения рязличных точек зрения в плане психологии. Совершенно аналогичную ситуацию в 
плане фразеологии имеем в случае так называемой «замещенной прямой речи - когда автор говорит за своего героя, вкладывая в его уста то, что он до $\pi$ е в 6 ы 6 ы $л$ сказать в соответствующей ситуации. См. приведенный выше ${ }^{19}$ пример из пушкинского -Кавказского пленника", когда автор за казака прощается с его родиной. Таким образом, автор здесь говорит от лица своего героя и вместе с тем от своего собственного лица; их точки зрения совмещены, причем совмещение имеет место в данном случае на уровне фразеологии.

Самый прием совмещения точек зрения путем подмены точки зрения персонажа точкой зрения рассказчика (на том или ином уровне) можно было бы обозначить соответственно как случай использования «замещенной точки зрения. «Замещенная точка зрения может проявляться, по-видимому, и в плане идеологии (когда оценка с точки зрения персонажа подменяется оценкой с позиции повествователя).

Наконец, в плане пространственно-временно́й перспективы сюда подпадает, например, та достаточно распространенная ситуация, когда описание привязано к пространственной позиции некоторого персонажа (т.е. используется его пространственная точка зрения), но при этом дается кругозор более широкий, нежели поле зрения этого последнего. Таким образом, рассказчик подменяет пространственную точку зрения данного персонажа тем, что бы он сам (т.е. рассказчик) увидел на его (персонажа) месте 20 .

19 С. 64 наст. изд.

20 В әтом плане можно трактовать и приведенный выше (с. 139-140) пример с Николаем Ставрогиным (но там, кроме того, имеет место еще несовпадение пространственной и психологическон точек зрения). 


\section{6 Некоторые специальные проблемы композиция художественного текста}

Нашей задачей до сих пор было иллюстрировать различие точек зрения, проявляющееся на разных уровнях и в разнообразных отношениях. При этом мы намеренно отвлекались от некоторых спедифических композиционных возможностей, представляющих собой как бы дополнительное усложнение тех композиционных приемов, которые были описаны выше. Мы рассмотрим сейчас две такие проблемы.

\section{Зависнмость точки зрения \\ от предмета оптсандя}

Мы рассматривали до сих пор наиболее простой и общий случай организации художественного текста - когда выбор авторской позиции зависит исключительно от автора, ведуцего повествование.

Можно указать, однако, и на другую возможность - когда тот или иной принцип описания (в частности, выбор точки зрения) зависит не только от того, к т о описывает, но и от того, ч т о описывается, т.е. определяется не только о п и сы в а 1 щ и м с у бъ ектом (автором), но и о пи сы ваемым объе к т о м (объектом описания при этом может быть то или иное действующее лицо или та или иная ситуация). Таким образом, типологически различные привципы описания, вообще говоря, характерные для разных произведений или даже для разных авторов, могут сосуществовать и в одном произведении - применительно к разным объектам описания.

Вообще поведение того или иного героя в художественном произведении - в самых разнообразных его аспектах - может в принципе мотивироваться либо его личностными характеристиками (т.е. тем, ч т о он собой представляет), либо ситуапией, в которую он попадает (т.е. тем, г д е он находится) $)^{1}$. Это различде характерно,

${ }^{1}$ Ср.: Плтигорский и Успенский, 1967, с. 17-18. Там же- психологическое освещение данной проблемы. 
вообще говоря, для разных литературных пронзведений или направлений, хотя в принципе и в одном произведении может иметь место ковтамивация әтих двух тендевций. У таких писателей, например, как Стендаль, Диккенс, Толстой, конкретные ситуапии вытекагот обычно из личностных свойств и характеров персонажей. Обратную тенденцию можно иллюстрировать на примере фольклора, где поведение героя может быть детерминировано конкретным местом, в которое ов попадает ${ }^{2}$.

Зависимость используемой точки зрения от объекта описания проще всего показать на примерах, относящихся к п $л$ а н у ф р а е о логи и. При рассмотрении этого плана мы отмечали, что та или иная фразеологическая точка зрения проявляется прежде всего в области собственных имен и вообще всевозможных наименований. Иначе говоря, то или иное наименование действующего лица в авторской речи служит показателем той позиции, которую принимает по отношению к данному лицу автор при повествовании ${ }^{3}$. Но при этом любопытно то обстоятельство, что в о т ношении разных персонажей здесь мо гут применяться различные приниипы о п и с а н и я. Так, может оказаться, что одни лица описываются в произведении с нескольких точек зрения, тогда как в отношении других лиц смена точек зрения может быть нехарактерна или даже вовсе невозможна. Самый принцип описания, таким образом, зависит здесь целиком от о б з е т а о п и с а и я.

Подобный вывод, в частности, может быть сделан из рассмотрения текста «Войны и мира». Если отвлечься от я в н ы $\mathbf{x}$ случаев несобственно-прямой речи - таких случаев, когда из непосредственного контекста видно, к о м у (т.е. какому конкретному лицу из упоминаемых в данном контексте) принадлежит та или иная точка зрения, используемая в авторском тексте, - нетрудно убедиться, что одни лица здесь на всем протяжении повествования именуются одинаково, т.е. называются одним и тем же именем (или же ограниченным числом имен-вариантов), тогда как другие именуются в разных ситуациях различным образом.

2 См.: Неклюдов, 1966. Ср., вместе с тем: Лотман, 1965a, где раскрывается характерная для средневекового сознания Древней Руси связъ изменения нравственного статута и перемещения в пространстве.

3 См. выше, с. 40 и сл. 
Так, Наташа Ростова у Толстого едва ли не всегда выступает как -Наташа (или «Наташа Ростова»). Не так, однако, Николай Ростов: он именуется в авторском тексте +Nicolas», •Николенькой", Николушкой (автор, очевидно, использует в данном случае точку зрения его родных), Ростовым (точка зрения его сослуживцев по полку или его знакомых в светском обществе), ‘молодым графом (точка зрения дворовых), «Николаем», ‘Николаем Ростовым и т.п. Иногда автор может описывать его и совершенно уже со стороны - как полностью незнакомого человека, например, в сцене охоты в Отрадном: ‘Сбаки го р я че го, м о л о дого охо т н и а Ростов а... - пишет Толстой (т. $\mathrm{X}$, c. 244), словно мы впервые с ним встречаемся, - и такое отчуждение наступает после того, как совсем недавно нак о нем сообщалось как о ‘Николушке» и т.п.!

Можно сказать, что если Наташу Толстой описывает с какойто постоянной позиции (автор как бы отказывается в данном случае становиться на точку зрения других, но предпочитает смотреть с собственной точки - изображая ее такой, какой он сам ее видит), то Николая он описывает со многих разных позиций, показывая его как бы то в одном, то в другом освещении.

Подобная дисперсия точек зрения (или же, напротив, отсутствие этой дисперсии) является, несомненно, важным композиционным моментом.

То же самое может быть констатировано, если обратиться к другим возможностям проявления фразеологической точки зрения. Мы отмечали, например, что речь французов (или фрапцузская речь русских дворян) в «Войне и мире может даваться то по-французски, то по-русски - и ставили это в связь с соответствующим изменением авторской позиции по отношению к описываемому персонажу (лицу, которому принадлежит прямая речь ${ }^{4}$.) Но интересно в этой связи, что речь некоторых персонажей - например, капитана Рамбаля - дается только по-французски: позиция автора по отношению к данному персонажу остается все время одной и той же (можно сказать, что Рамбаль интересует автора исключительно в плане «внешнего наблюдения). Только по-французски передается и речь полковника Мишо (характерен его разговор с Александром (т. XII, с. 10-13), который весь дан по-французски, что подчеркивает внешнюю авторскую позицию).

4 См. выше, с. 65 и сл. 
Точно так же и несобственно-прямая речь может использоваться автором в большей или меньшей степени в зависимости от объекта описания.

Итак, речевая характеристика может зависеть не только от того, от ч в е го л и ц а говорит автор, но и от того, про к о го или в к а к о й с и т у а и и он говорит.

Подобная зависимость языковых приемов описания от предмета речи характерна вообще для языка и отнодь не ограничивается рамками художественного текста. Действительно, в самых обычных условиях повседневной речи нетрудно наблюдать связь между различными лингистическими признаками (лексическими, фонетическими и т.п.) и тем, о чем идет речь. Так, например, когда мы говорим о маленьком ребенке или о чем-то, к нему относящемуся, нередко появляется особая интонация, вообще особая фонетика (то, что принято называть “сосюканьем•), особая лексика и даже особая грамматика (в частности, употребление уменьшительных суффиксов, факультативное вообще в русском языке, здесь может характеризоваться обязательностью). Таким образом, предмет речи может определять особенности языка.

Аналогичная зависимость может наблюдаться и в плане идеологии. Здесь можно сослаться прежде всего на "постоянные эпитеты в фольклоре; с одной стороны, как отмечалось, они часто служат для выражения идеологической точки зрения автора, с другой стороны, их употребление обусловлено не стилько самим автором, сколько объектом описания: они с обязательностью появляются каждый раз при упоминании соответствующего объекта. Постоянный эпитет здесь входит в общую єэтикетную ситуацию», которая связывается в эпическом повествовании с тем или иным объектом повествования. Если писатель описывает поступки князя - он подчиняет их княжеским идеалам поведения; если перо его живошисует святого - он следует этикету церкви; если он описывает поход врага Руси - он и его подчиняет представлениям своего времени о враге Руси. Воинские эпизоды он подчиняет воинским представлениям, житийные - житийным, эпизоды мирной жизни князя - этикету его двора и т.д.» ${ }^{5}$ Сама описываемая ситуация вытекает, следовательно, из прелмета описания; в то же время ею определяется и идеологическая позиция автора.

${ }^{5}$ См.: Лихачев, 1967, с. 95; о6 затикетной ситуации см. также: Лихачев, 1961. О постоянных эпитетах см.: Веселовский, 1940. 
Интересно проследить ту же особенность у такого писателя, как П.И.Мельников-Печерский. Ср. образ Алеши Лохматого в его эпопее « Весах и « На горах , поведение которого и авторское отношение к которому определяется не непосредственно его личностными качествами, но прежде всего тем м е то м, в котором он оказывается (ва протяжении повествования отношение автора к Алеше резко меняется; при этом изменяется-то в общем не сам Алеша, а его место в жизни; из села в город, из работниқов в купцы и т.п.).

Аналогичным образом в •Войне и мире Толстого авторское отношение к Соне меняется в зависимости от ситуации, в которой она находится. Между тем отношение Толстого к Элен остается одним и тем же на протяжении всего романа и не меняется даже в случае ее смерти - характерно, что о смерти Элен говорится вскользь и так, как будто речь идет об очередной ее выходке.

Итак, отношение к герою составляет здесь функцию от «мес та (в широком смысле), в котором тот оказывается, находясь в зависимости не непосредственно от субъекта описания, а от того, ч т о описывается.

Совершенно так же и пространственно-временна́я позиция автора по отношению $к$ персонажу в произведении может зависеть не только от особенностей данного автора, но и от свойств данного персонажа: одни персонажи могут описываться с какой-то определенной позиции, другие же- - нескольких различных позиций.

То же, наконец, можно проследить и в плане психологии. Как мы видели, различные персонажи в произведении могут быть представлены различным образом: если одни персонажи выступают - постоянно или время от времени - как носители психологической точки зрения (т.е. автор пользуется их восприятием), то другие показаны исключительно со стороны, глазами стороннего наблюдателя.

В качестве аналогии к вышесказанному можно сослаться на систему изображения в иконописи, где семантически более важные фигуры изображаются преимущественно как неподвижные, образуя как бы дентр, относительно которого строится изображение, тогда как фигуры менее важные передаются в движении, будучи фиксированы в их отношении к этому центру. Иначе говоря, более важная фигура описывается с какой-то постоянной точки зрения, тогда как другие - с разных и достаточно случайных точек зрения ${ }^{6}$.

6 См. с. $279-280$ наст. изд. 
Итак, различные принципы описания, которые, вообще говоря. могут считаться характерными для определенных авторов, могут быть представлены в одном и том же произведении, будучи обусловлены спецификой изображаемого материала. Произведение подобного рода стронтся таким образом, как если бы разные объекты данного произведения описывались разными авторами (следующими различным принципам организации художественного повествования). Такие случаи могут трактоваться, соответственно, как результат дальнейшего усложнения тех элементарных композиционных возможностей, которые были рассмотрены выше. Подобные приемы композиции имеют, тем самым, как бы вторичный характер.

\footnotetext{
"Точка зренкя"

в аспекте прагматикн
}

Несопнаденпе позицин автора и читателя

Выше, говоря о различных точках зрения в произведении искусства и о динамике точки зрения при описании, мы имели в виду точку зрения автора, т.е. того, кто производит описание (повествование, изображение); иначе говоря, ставился вопрос о том, с чьей точки зрения описывает автор. Обычно эта точка зрения является одновременно и точкой зрения воспринимајещего описание адресата (читателя, зрителя), который как бы присоединяет себя к автору и вместе с ним принимает то ту, то другую точку зрения. Таким образом, в большинстве случаев позиция описывающего и позиция воспринимающего совпадает, и нет нужды различать эти позиции.

Однако возможны и такие случаи, когда имеет место несовпадение позиции автора и позиции читателя (зрителя), причем это несовпадение сознательно предусмотрено автором.

Следует оговориться, что мы отвлекаемся здесь от возможности авторской неудачи, когда позиция автора и позиция читателя не совпадают вопреки воле автора - просто потому, например, что автору не удалось достичь поставленной цели, или же потому, что читатель исходит из позиций, на которые не рассчитывал автор. (Естественно, что случаи несовпадения авторской и читательской позиции возрастают по мере удаления читателя от автора во времени или в пространстве.) 
Итак, мы говорим здесь о совпадении и несовпадении авторской и читательской позиций только в том случае, когда это совпадение или несовпадение входит в авторский замысел.

Такое несовпадение, в частности, может иметь место при разного рода комических эффектах. Укажем прежде всего, что оно лежит в основе әффекта и р о н и .

Приведем примеры авторской иронии, основанной на нарочитом противопоставлении точек зрения ввтора и читателя. Вот что пишет, например, протопоп Аввакум, укоряя иконописцев-никониян, которые стали по-новому, на «фряжский манер, писать святых на иконах: „Спаси Бог су вас - выправили вы у них морщины-те у бедных: сами они в животе своем не догадалися так зделать, как вы их учинили!॰7. Таким образом, автор (Аввакум) намеренно принимает здесь такую точку зрения, которая, по его замыслу, должна быть противоположна точке зрения читателя; автор как бы юродствует, становясь на такую позицию, которая для него самого, конечно, неприемлема. При определенном подходе можно было бы сказать, что позиция автора тут раздваивается, но точно так же правомерно считать, что в данном случае расходятся позиции автора и читателя, причем автор сознательно разыгрывает такую роль, которая, вообще говоря, ему отнюдь не свойственна.

Еще пример - на этот раз из Толстого (то место из «Войны и мира*, где описывается мнение света по поводу развода Элен с Пьером и предстоящего ее нового замужества). Передавая общественное мнение, Толстой пишет:

Были действительно некоторые закоснелые люди, не умевшие подняться на высоту вопроса и видевшие в этом замысле поругание таинства брака; но таких было мало, и они молчали... (т. XI, с. 286).

Толстой явно говорит здесь не от своего лица. Принятая им в данном случае точка зрения совершенно очевидно расходится с его общей позицией (которая в данном случае отсутствует, но о которой мы достаточно легко можем догадываться) и с той позицией, на которой, по замыслу автора, должен находиться читатель.

Примеры подобного рода, конечно, легко было бы продолжить. Можно думать, что подобное несовпадение авторской и чита-

${ }^{7}$ Из беседы чо внешней мудрости*. См.: Аввакум, 1927, стлб. 291. 
тельской позиций составляет вообще существо приема иронии; при этом характерно, что автор говорит или действует от некоего лица, но само это лицо выступает не как с у б з е к т, а как о б ъ е к т оценки (на этом основании выше мы могли говорить - в несколько ином аспекте рассмотрения - о характерном для иронии несовпадении идеологической и какой-либо другой точки зрения ${ }^{8}$ ). Ирония, тем самым, предстает как специальный случай п р и т в о р т в в автора ${ }^{9}$, которое противостоит е с т с т е н н о й (ло определению) позиции читателя.

Приведенные примеры иллюстрируют случай, когда автор на время меняет свою позицию; до этого идеологические позиции автора и читателя совпадали, и таким образом читатель по инерции остается на старой позиции, тогда как автор неожиданно от нее отступает. В других случаях может иметь место и постоянное (сохраняющееся на всем протяжении повествования) несовпадение между позициями автора и читателя (это возможно, например, при «сказе» - ср. рассказы Зощенко, где лицо, с точки зрения которого ведется повествование, одновременно выступает и как предмет оценки с точки зрения читателя) ${ }^{10}$.

Если приведенные выше примеры демонстрируют случай динамики авторской позиции по отношению к позиции читателя, то нетрудно привести и такие случаи, когда имеет место, напротив, динамика позиции читателя относительно позиции автора. В то время как ситуация первого рода возможна, в частности, в случае и рон и и, то ситуация второго рода характерна, например, для г р о т е с к a.

Достаточно вспомнить, например, вранье Хлестакова в «Ревизоре Гоголя. Хлестаков врет, увлекаясь, и доходит до масштабов почти космических. Только что мы (т.е. читатель) могли воспринимать происходящее как относительно реальное, т.е. приспособиться к той условной действительности, которая изображается на сцене, как вдруг нам преподносится нечто, явно выходящее за пределы всякой пеальности. Таким образом, меняется сама норма на-

8 См. с. $135-136$ наст. изд.

9 В прямом соответствии, между прочим, с греческой этимологией этого слова: вipové́ $\alpha$ - букв. "притворство .

$10 \mathrm{Cp}$. также трактовку лесковского «Левши (хотя и в иных терминах) в работе: Виноградов, 1959, с. 123-130. 
шего восприятия, допущение того, что может, а чего не может быть $^{11}$; иначе говоря, меняется точка зрения читателя, система его оценок, и эта динамика читательской точки зрения входит в расчеты автора произведения 12 .

Соответствующая динамика позиции читателя (эмпирическое приспособление к неизвестной ему норме) достаточно обычна в самых различных жанрах художественной фантастики.

Аналогичный сдвиг точки зрения воспринимающего (читателя) очень часто имеет место в анекдоте - когда все происходящее воспринимается сначала с одной точки зрения, а потом неожиданно оказывается, что воспринимать надо было с совершенно другой (т.е. что рассказчик стоит на другой позиции). Та или иная композиция, сводящаяся к определенной динамике позиции воспринимающего (относительно ввторской позиции), по-видимому, вообцце характерна для комического.

\section{Семантика, скеттктике и mparmatuka композициониото построения}

Если применить к произведению искусства известное семиотическое разделение на семантику, синтактику и прагматику, то можно говорить соответственно о семантическом, синтактическом и прагматическом уровнях произведения: с е м а н т и че с к й уровень исследует отношение описания к описываемой действительности (отношение изображения к изображаемому), с и н т а к и ч ски й уровень исследует внутренние структурные закономерности построения описания, наконец п р а $\mathbf{~ м ~ а ~ т и ~ - ~}$ ч е с и й уровень исследует отношение описания к человеку, для которого оно предназначается. Соответственно можно говорить

11 Ср. в этой связи замечание В.В.Гиппиуса о том, что в приеме шаржа искажение претерпевает не сама действительность», а некоторая ^норма (Гиппиус, 1966, с. 296); в то же время искажение нормы естественно связывать именно с изменением точки зрения.

12 При определенном подходе можно было бы считать, что в подобной ситуации изменение претерпевает как читательская, так и авторская точка зрения; но существенно при такой интерпретации, что точка зрения читателя отстает от авторской - и, таким образом, мы все равно вправе констатировать динамику точки зрения читателя относительно позиции автора. 
и о семантическом, синтактическом и прагматическом аспектах к о м п о з и ц и художественного произведения (т.е. проблемы точки зрения).

В этом смысле с е м а т и к а композиционного построения рассматривает отношение точки зрения к описываемой действительности и, в частности, то искажение, которое претерпевает действительность при передаче через соответствующую точку зрения. Нередко одна и та же действительность (одно и то же событие) описывается с разных точек зрения, каждая из которых ее невдекватно воспроизводит (по-своему ее искажает); при этом различные точки зрения могут взаимно дополнять одна другую, в своей совокупности позволяя читателю получить адекватное представление об описываемом факте. Проблема подобной организации различных точек зрения в произведении относится именно к семантическому аспекту композиции.

Между тем с и н т а к т и а композиционного построения рассматривает отношения различных точек зрения, участвующих в произведении, безотносительно к воспроизводимой действительности. Здесь может ставиться, в частности, вопрос о функциональном значении использования той или иной точки зрения в произведении (т.е. внутреннем синтактическом значении, которое устанавливается без выхода за пределы данного произведения). Именно синтактический аспект композиции преимущественно рассматривался в предшествующих главах данной работы.

Наконец, п р а г а ти к а композиционного построения рассматривает проблемы композиции произведения в связи с его читателем, т,е. тем, кому вдресован данный текст. Композиционное построение может специально предусматривать определенное поведение читателя - таким образом, что последнее входит в расчеты автора произведения, как бы специально им программируется $^{13}$. В частности, автор, как мы это видели, может специально

13 Следует еще подчеркнуть, что мы говорим здесь о прагматике художественного произведения исключительно в плане его композиции.

Если же говорить вообще о прагматике художественного произведения, то здесь возникает более общая проблема классификации произведений в зависимости от прагматического отношения к ним читателя (причем здесь могут различаться отношения, предусмотренные автором и не предусмотренные им). Так, например, одни произведения читаются для того, чтобы узнать, ч что будет далыше (иногда это стремление проявляется настолько сильно, что даже заглядывают в конец), другие - чтобы по-новому взглянуть на какие-то 
рассчитывать на определенную динамику позиции читателя ${ }^{14}$. Различные композиционные отношения между авторской и читательской точками зрения проявляются прежде всего в плане их относительного кругозора, относительной осведомленности о происходящих событиях. В одних случаях автор обладает абсолютным знанием о происходящих событиях, тогда как от читателя те или иные обстоятельства до поры до времени могут быть скрыты, кругозор же героев еще более ограничен. В других случаях автор налагает какие-то сознательные ограничения на свои знания, причем он может не знать того, что известно какому-либо персонажу произведения ${ }^{15}$. Наконец, может быть случай, когда кругозор автора (рассказчика) сознательно ограничен по сравнению с кругозором читателя, и т.п.

В аспекте процесса коммуникации мы можем трактовать произведение как с о обще н и е, автора как отп равите ля сообщения и читателя как а д р с а т а сообщения. Соответственно, в этом плане мы можем различать точку зрения автора (отправителя), точку зрения читателя (адресата) и, наконед, точку зрения того лица, о котором идет речь в произведении (т.е. того или иного персонажа произведения).

Далее, какие-то из данных трех типов точек зрения могут *склеиваться друг с другом, т.е. не различаться при повествоваиии. Так, может не различаться позиция автора и позиция читателя или позиция автора и позиция персонажа.

Заметим при этом, что если позиция читателя имеет принципиально в н е ш н и й характер по отношению к повествованию (в самом деле, читатель по необходимости смотрит на произведение извне), а позиция персонажа - характер принципиально

проблемы, и т.п. (Соответствующей прагматической задачей произведения обуславливается, между прочим, и то, что одни пропзведения легко перечитывать, тогда как другие перечитываются с трудом или с меньшим удовольствием.) Понятно, что в рамках настоящей работы мы не имеем возможности останавливаться на этой достаточно сложной и специальой проблеме.

14 О прагматических проблемах композиции в живописи (в частности, учет позиции и движения зрителя при построении изображения) см. с. 247 наст. изд.

15 Ср. выше, с. 130-131. O проблеме авторского знания в более обцем плане будет сказано ниже (с. 207 и сл.). 
в н у т р н н и й, то позиция ввтора может меняться в этом отношении. Так, если автор принимает точку зрения читателя, мы имеем случай описания событий извне (с какой-то посторонней позиции), а в том случае, когда автор принимает точку зрения персонажа, - описание изнутри.

Подробнее проблема *внешней и * внутренней точки зрения будет рассмотрена в следующей - заключительной - главе нашей книги. 


\title{
7 Структурная общность разных видов искусства. Общие принциты организации произведения В живописи и литературе
}

\author{
Внешняя и внутренняя \\ точки зрения
}

\author{
Прояпление \\ внешней п внутренпей \\ точек зрепія \\ на разилх уровнях \\ аналтва
}

Мы выделили несколько общих планов, где вообще может проявляться различие точек зрения; при этом каждый раз мы стремились прежде всего рассмотреть специфические (для соответствующего уровня анализа) возможности проявления точек зрения.

Нетрудно видеть, между тем, что по крайней мере одно противопоставление точек зрения имеет общий, как бы "сквозной характер, т.е. выявляется в каждом из рассмотренных выше планов. Противопоставление это мы условно обозначили как противопоставление "внешней и *внутренней точек зрения.

Иначе говоря, в одном случае автор при повествовании зани мает позицию заведомо вн е ш н 10 по потношению к изображаемым событиям - описывая их как бы с о с т о роны. В другом случае, напротив, он может помещать себя в некоторук В н у т р е н н ю ю По отношению $к$ повествованию позицию: частности, он может Принимать точку зрения того или иного ұчастника повествуемых событий или же он может занимать позицию человека, находящегося на поле действия, но не принимающего в нем участия.

В свою очередь при общей внутренней позиции автора по отношению к действию, которое он описывает, может различаться опять-таки внутренняя или внешняя позиция по отношению $к$ тому или иному персонажу. Действительно, в том случае, когда писатель принимает при оПисании точку зрения того или иного дей- 
ствующего лица, можно говорить о том, чте данный персонаж описывается с некоторой внутренней по отношению $к$ нему точки зрения. Между тем, если писатель ведет репортаж с поля действия, не ставя себя в позицию непосредственного участиика событий, авторская точка зрения по необходимости является внешней по отношению $\mathrm{k}$ описываемым персонажам (автор использует при описании точку зрения стороннего наблюдателя), но внутренней по отношению к самому описываемому действию.

Для иллюстрации описания последнего типа можно сослаться на одно место из "Мастера и Маргариты М.Булгакова. Описывается разговор Ивана и Мастера в сумасшедшем доме; при этом разговор происходит в палате Ивана, где, кроме них двоих, никого нет. Автор сообщает: “...гость начал говорить Ивану на ухо так тихо, что то, что он рассказал, стало известно одному поэту только, за исключением первой фразы.... Далее приводится эта фраза, и описание приобретает подчеркнуто остраненный характер: описывается мимика героя, внешнее впечатление от его поведения, но слова его до нас не доносятся - автор (а вместе с ним и читатель) как бы не может их слышать. Затем нам сообщается: „...когда перестали доноситься всякие звуки извне, гость отодвинулся от Ивана и заговорил погромче 1 - и таким образом мы получаем возможность услышать конец рассказа Мастера.

Совершенно очевидно, что автор использует в данном случае точку зрения незримого наблюдателя, присутствующего в описываемой сцене, но не принимающего в ней участия. В других случаях эта точка зрения не проявляется столь явным образом.

Надо сказать, что значение внешней точки зрения как композиционного приема следует из того обстоятельства, что она лежит в основе известного явления, получившего в свое время название "остранения". Действительно, сущность явления остранения в значительной мере сводится к использованик принципиально новой - ч у ж о й - точки зрения на знакомую вещь или знакомое явление, когда художник «не называет вещь ее именем, но описывает ее как в первый раз виденную, а случай - как в первый раз произошедший ${ }^{2}$. Иначе говоря, в аспекте рассматриваемой нами

${ }^{1}$ См.: Булгаков, 1988, с. 416.

2 См.: Шкловский, 1919 , с. 106.

Заметим, что в явлении остранения помимо использования чужой точки зрения есть и другая сторона (определенным образом связанная с вышеупомянутой): прием затруднения формы, специальное увеличение трудности вос- 
проблематики прием остранения может быть понят как переход на точку зрения постороннего наблюдателя, т.е. использование позиции принципиально внешней по отношению к описываемому явлению.

' Различия внешней и внутренней точек зрения при повествовании, как мы уже имели возможность видеть, в принципе могут проявляться в каждом из рассмотренных выше планов (причем могут реализоваться различные возможности сложного композиционного построения, сочетающего - на разных уровнях - внутреннее и внешнее описание одного и того же объекта).

Так, в п л н е и д е ол оги и тот, с чьей точки зрения оцениваются описываемые события, может выступать, например, в качестве непосредственного участника действия (главного героя или второстепенного персонажа ${ }^{3}$ ) или же даваться в качестве п о те н ц и ль н о г действующего лица, которое хотя и не принимает участия в повествуемых событиях, но, вообще говоря, вполне вписывается в круг действующих лиц. И в том и в другом случае мир дается при повествовании как бы представленным (в плане идеологической оценки) и з н т р и, а не извне.

В других же случаях идеологическая оценка производится с некоторых заведомо внешних по отношению к самому повествованию позиций - с позиций именно автора в собственном смысле этого слова (а не рассказчика), т.е. лица, в принципе противопоставленного своим героям, находящегося н а д ними, а не среди них. Подобное идеологическое отчуждение характерно, в частности, для с а т и р ы 4 .

В плане фразеологи и всевозможные случаи использования в авторской речи чужого слова (формы несобственнопрямой речи, внутреннего монолога и т.п.) могут свидетель-

приятия - с тем чтобы возбудить активность воспринимающего, заставить его в процессе восприятия вещи пережить самую вещь.

3 См. выше, с. $22-24$.

$4 \mathrm{Cp}$. противопоставление средневекового карнавального юмора и сатиры нового времени у М.М.Бахтина. Бахтин характеризует народный юмор средневековья как смех, направленный на самого себя (когда смеющийся не исключает себя из того мира, над которым смеется), и вндит в этом одно из принципиальных отличий народно-праздничного смеха от «чисто сатирического смеха нового времени", где смеющийся «ставит себя вне осмеиваемого явления, противопоставляет себя ему», зная только отрицающий смех (см.: Бахтин, 1965, с. 15).

Вообще о характерности внутренней точки зрения для средневекового мировосприятия, а внешней позиции для нового времени - см. ниже. 
ствовать о внутренней точке зрения по отношению к описываемому персонажу. В то же время такое явление, как «с к а з* (в его чистой форме), свидетельствует об использовании при повествовании точки зренил. внутренней по отношению к описываемому действию, но внешней по отношению $к$ действующим лицам.

С другой стороны, мы видели, что фразеологическое противопоставление внешней и внутренней точек зрения релевантно не только для ввторской речи, но и при передаче прямой речи действующих лиц. Как мы старались показать в соответствующем разделе ${ }^{5}$, натуралистическое воспроизведение иностранной или неправильной речи в общем свидетельствует о некотором отчуждении автора, т.е. об использовании им какой-то внешней позиции. При этом в одних случаях здесь выступает внешняя позиция описываюшего по отношению $к$ описываемому персонажу (примером может служить картавость Денисова), в других же случаях - внешняя позиция по отношению вообще $\kappa$ описываемому действию (соответственно может трактоваться французский нзык в «Войне и мире»).

То же противопоставление выступает со всей очевидностью и в плане п ростран ствен но-в ре менно́ й ха ракт е р и с т и к и. В плане собственно пространственной характеристики совпадение позиции описывающего с позицией того или иного персонажа указывает на использование внутренней (по отношению к данному персонажу) точки зрения, тогда как отсутствие такого совпадения (в частности, в рассмотренных выше случаях «последовательного обзора*, «немой сцены», точки зрения «птичьего полета и т.п.) говорит об использовании позиции внешней. Точно так же в плане временно́й характеристики использование внутренней точки зрения имеем, например, в том случае, когда временна́я позиция повествователя синхронна описываемому им времени (он ведет свое повествование как бы из «настоящего участников действия), - тогда как внешняя точка зрения представлена при ретроспективной позиции автора (қогда автор сообщает то, чего не могут еще знать персонажи, - как бы производя повествование не с точки зрения их «настоящего , а с точки зрения их «будущего ).

Что же касается п ан а п и и о логи и, то из рассмотрения в соответствующем разделе должно быть очевидно, что противопоставление внешней и внутренней позиций является основным в этой сфере (см. сказанное выше об описании «извне и опи-

5 См. выше, с. $73-75$. 
сании «изнутри в психологическом аспекте). Понятно при этом, что речь может идти здесь только о внешней или внутренней позиции автора по отношению к некоторому п е р с о а ж у, а не по отношению к описываемому действию.

\section{Совмецение \\ внешпей и виутренвей точек зрения (на определенном уровне анализа)}

Выше (в главе. пятой) мы отмечали общую возможность совмещения различных точек зрения при повествовании - совмещения, которое может проявляться как на разных уровнях произведения, так и на одном и том же уровне. Точно так же мы можем отметить теперь возможность совмещения (на том или ином уровне) описания, использующего внешнюю точку зрения, и описания, использующего точку зрения внутреннюю. Мы проследим эту возможность по разным планам.

П л а и де о л о г и. Анализируя структуру произведений Достоевского (преимущественно в плане идеологической оценки), М.М.Бахтин пишет: “Сознание героя дано как другое, чужое сознание, но в то же время оно не опредмечивается, не закрывается, не становится простым объектом авторского сознания ${ }^{6}$. Иначе говоря, можно считать, что здесь имеет место совмещение внутренней (по отношению к данному персонажу) и внешней точек зрения - причем данные точки зрения различаются исключительно в плане идеологии.

П л а н П с и х о л о г и и. Совершенно аналогичное совмещение внутренней и внешней точек зрения - но проявляющихся на этот раз в плане психологии - можно усмотреть в разбиравшемся выше случае с Митей Карамазовым (внутреннее состояние которого подробно описывается, но при этом умалчивается о том, что его больше всего звботит и к чему он должен соответственно постоянно возвращаться в своих мыслях) ${ }^{7}$. В самом деле, мы можем считать, что при описании Мити совмещены две различные точки зрения, которые мы исследовали при рассмотрении плана психологии, - точка зрения изнутри (предполагающая описание

${ }^{6}$ См.: Бахтин, 1963, с. 7.

7 См. с. 124-125. 
внутреннего состояния персонажа) и точка зрения извне, т.е. отчужденная точка зрения, использующая позицию стороннего наблюдателя (предполагающая, наоборот, отсутствие описания внутреннего состояния персонажа). Указанное совмещение имеет место вообще на протяжении всего повествования, когда речь идет о Мите, но с наглядностью оно проявляется лишь тогда, когда эти точки зрения вступают в известный конфликт, начиная противоречить одна другой ${ }^{8}$.

План простран ствен но-в ре менно́ й перс п е к т и в ы. Совмещение точек зрения (персонажа и рассказчика), различающихся во времени, уже рассматривалось нами при разборе композиционных проблем, связанных со временем. Мы имеем в виду тот случай, когда совмешаются, во-первых, временна́я позиция некоторого описываемого персонажа (его *настоящее ) и, во-вторых, временна́я позиция рассказчика, знающего дальнейший ход событий (и соответственно смотрящего - по отношению к данному персонажу - из его будущего) ${ }^{9}$ - причем описание ведется с одновременным использованием обеих позиций. Этот случай правомерно рассматривать опять-таки как случай совмещения внешней (по отношению к описываемым событиям) и внутренней позиций повествователя, но проявляющихся на этот раз в плане пространственно-временно́й характеристики.

Пл а н фра з е логи и. Совмещение внешней и внутренней позиций автора по отношению к некоторому пе р с он а ж у рассматривалось выше на примере тех случаев, когда описание дается параллельно в двух планах - в плане авторской речи и в плане индивидуальной фразеологии какого-то действующего лица. См. приводившиеся выше ${ }^{10}$ примеры подобного совмещения из “Войны и мира" со ссылкой на восприятие Наполеона: «Увидев... расстилавшиеся степи (les.Steppes).... (т. XI, с. 8) и т.п.

В то же время совмещение внешней и внутренней позиций автора по отношению ко всему действию в целом (а не некоторому персонажу) представлено в случае описания охоты в Отрадном, которое, как уже говорилось, ведется сразу в двух планах - со специальной охотничьей фразеологией и с фрязеологией нейтральной ${ }^{11}$.

\footnotetext{
8 Что мы и старались продемонстрировать выше (с. 125).

9 См. выше, с. $93-94$.

10 Cм. с. 77 .

11 См. примеры выше, с. 78-79.
} 
Внешняя и внутренняя точки зрения в изобразительном искусстве

Мы отмечали различные возможности проявления внешней и внутренней точек зрения в словесном тексте. Необходимо указать, что подобное противопоставление имеет не меньшее значение при построении изображения в живописи.

В самом деле, в одних случаях художник явно занимает позицию наблюдателя, находящегося вне изображаемой действительности; соответственно, он и строит изображение с точки зрения такого наблюдателя: между ним и тем миром, который он изображает, находится мысленный барьер, и таким образом он как бы смотрит на мир через окно. Именно такая - внешняя по отношению к изображаемой действительности - позиция художника была обоснована теоретиками эпохи Возрождения, по мысли которых картина есть не что иное, как "окно в природу (cp. "fenestra aperta* Альберти, «pariete di vetro Леонардо да Винчи). Со времени Ренессанса такая позиция художника становится обычной в европейском изобразительном искусстве.

Между тем, для более раннего искусства характерна принципиально иная позиция художника. Древний художник не мыслит себя вне изображения, но, напротив, помещает себя как бы внутрь изображаемой действительности: он изображает мир в к р у г с е 6 я, а не с какой-то отчужденной позиции, он занимает, таким образом, внутреннюю по отношению к изображению позицию ${ }^{12}$.

Использование внутренней или внешней точки зрения в изобразительном искусстве может проявляться, в частности, в системе перспективы. Так, прямая и линейная перспектива, характерная для ренессансной и позднейшей живописи (предполагаюшая сокращение предметов по мере их удаления от зрителя), представляет мир таким, как он воспринимается ијвне (со стороны), с какой-то фиксированной точки зрения - В н $\in$ ш н ей по отношению $к$ изображаемой действительности. Напротив, так называемая обратная перспектива, характерная для древнего искусства (предполагающая сокращение предметов по мере их приближения к зрителю картины, т.е. к переднему плану), соответствует позиции именно внутреннего наблюдателя ${ }^{13}$.

12 См. примеры, приводимые на с. 253 и сл. наст. изд.

13 Подробнее об этом см. на с. 250 наст. изд. 
Рамки художественного текста

Проблема рамок

в разлитиых

семмотических сферах

Актуальность проблемы *рамок", т.е. границ художественного произведения, представляется достаточно очевидной. В самом деле, в художественном произведении - будь то произведение питературы, живописи и т.п. - перед нами предстяет некий особый мир - со своим пространством и временом, со своей системой ценностей, со своими нормами поведения, = мир, по отношению к которому мы занимаем (во всяком случае, в начале восприятия) позицию по необходимости внешнюю, т.е. позицию постороннего наблюдателя. Постепенно мы входим в әтот мир. т.е. осваиваемся с его нормами, ванивамся В него, получая возможность воспринимать его, так сказать, иинутрик, а не извне ; иначе Говоря, чнтатель становится - в том или ином аспекте - на- впутреннюю по отношению к данному произведению точку зрения. Затем, однако, най предстонт покинуть этбт мир - вернуться $k$ своей собственной точке зрения, от которой мы в большой степени абстрагировались в процессе восприятия художественного произведения.

При этом чрезвычайную важность приобретает процесс п е p e х о д а от мира реального к миру изображаемому, т.е. проблема специальной организации "рамок художественного изображения. Эта проблема предстает как проблема чисто композиционная; уже из сказанного может быть ясно, что онд непосредственным- бразом связана с определенным чередованием описания «ивне и описания *изнутри", - иначе говоря, переходом от *внешней ней точке зрения, и наоборот.

Г Преже чем перейти к собственно композиционной стороне проблемы "рамок», т.е. к описанию формальных способов их выражения в художественном тексте в терминах "точек зрения", необходимо подчеркнуть общую се м и ти че ск у ю актуальность данной проблемы.

Отметим прежде всего, что проблемы н а ч а л а и к о ц а имеют большое значение вообще для формирования системы культуры, т.е. общей системы семиотического представления мировосприятия (или более точно: системы семиотического соотнесения общественного и личного опыта). При этом бывают культуры с осо- 
бой отмеченностью начала, с особой отмеченностью конца (әхатологические), циклические системы и т.п. ${ }^{14}$.

Не менее актуальной выступает данная проблема в отдельных текстах культуры.

Укажем, в частности, на значение данной проблемы в храмовом действе, что выражается обычно в особых обрядах (ср. обязательное правило перекреститься при входе в храм в русской православной церкви). Это очень заметно, например, у старообрядцев (с их особенным вниманием к обрядовой стороне храмового действа), которые кладут при входе специальный «начал», т.е. сложную последовательность поклонов. Характерен в связи со сказанным упрек старообрядцев, обращенный к последователям никоновских реформ, у которых границы действа хотя и отмечены, но в значительно меньшей степени; старообрядцы говорят о никонианах, что у них в церкви нет н и н а ч а $л$, н и ко н ц 15 . Можно сказать, что необходимость как-то отмечать границы между специальным знаковым миром и миром повседневным - ощущается психологически.

Проблема "рамок" существует, конечно, и в театральном действии, где «рамки выражаются, в частности, в виде рампы, просцениума, занавеса и т.п. При этом в каких-то специальных ситуациях (часто обусловленных именно стремлением преодолеть рамки художественного пространства) актеры могут выходить в зрительный зал, даже обращаться к залу и вообще как-то вступать в контакт со зрителями - но тем не менее не нарушают границ между условным (представляемым) миром и миром повседневным. Можно сказать, что условное художественное пространство при этом меняется в своих границах, но сами. границы эти никоим образом не нарушаются. Ср. также всевозможные уличные мистерии, карнавалы и т.п., где экспансия театра со своими условностями в жизнь особенно очевидна.

Вообще подобные случаи әкспансии искусства в жизнь могут лишь изменить границы художественного пространства, но не могут их нарушить.

Границы художественного пространства нарушаются в принципиально противоположной ситуации - не в случае экспавсии искусства в жизнь, но в случае әкспансии жизни в искусство, т.е. в слу-

14 См.: Лотман, 1966а.

15 См.: Павел, 1878 , с. $34-35$. 
чае попыток зрителя (а не актера!) преодолеть художественное пространство и «вйти в текст художественного произведения, насильственно изменив его. Таков, например, известный эпизод покушения на картину Репина “Иван Грозный, убивающй своего сына», убийство средневековой толпо актера, изображавшего Иуду (аналогичное явление нередко имело место и в мусульманских религиозных мистериях), или знаменитое покушение зрителей в Новом Орлеане на жизнь актера, игравшего роль Отелло; сюда же могут быть отнесены и хорошо известные в этнографии случаи использования изображения для наведения порчи (с чем связаны соответствуюпие табу) ${ }^{16}$.

Само стремление нарушить граниды художественного пространства, вообще говоря, достаточно понятно - оно обусловлено стремлением предельно сблизить изображаемый мир и мир реальный в целях максимальной реалистичности (правдоподобия) изображения: отсюда следуют и всевозможные попытки преодолеть "рамки 17 . Укажем, например, на попытки избавиться от занавеса в современном театре, всевозможные случаи выхода изображения из рамы в искусстве изобразительном ${ }^{18}$; к своеобразным попыткам преодолеть художественное пространство (соединить жизнь и искусство) может быть отнесен и такой характерный мотив в литературе, как оживающий портрет (Уайльд, Гоголь).

-Действительность описывается символами или образами , - писал в этой связи П.А.Флоренский. *Но символ перестал бы быть символом и сделался бы в нашем сознании простою и самостоятельной реальностью, никак не связанно о с спмволизируемым, если бы описание действительности предметом своим имело бы одну только эту действительность: описанию необходимо, вместе с тем, иметь в

${ }^{16}$ См.: Лотман и Успенский, 1970. Попытки обсуждения героев произведения как живых людей, характерные как для наивного читательского восприятия, так и для традиционной критики (ср. о последней: Тынянов, 1965, c. 25), в известной степени также могут рассматриваться как случаи экспансии жизни в искусство, нарушающей его рамки.

17 Отсюда же и характерная для искусства XX века тенденция вводить в текст искусства какие-то конкретные реалии жизни - ср., например, куски газет в картинах кубистов (у Брака и др.); доведение этой тенденции до предела имеем в живописи «рор-art. Аналогичную роль играет введение в литературный текст документальной газетной хроники (ср., например, у Дос-Пассоса), всевозможных реклам, анонсов и т.п.

18 В средневековом и более древнем искусстве, особенно в миниатюре, нередки случаи, когда изображение выходит за пределы формально обозначенных границ художественного произведения, - например, рука или нога той или иной изображенной фигуры как бы «протыкает художественное пространство, показываясь по сю сторону очерченной рамки (илл. 3). 
виду и символический характер самых символов, т.е. особым усилием все время держаться сразу и при символе и при символизируемом. Описанию надлежит быть двойственным. Это достигается через критику символов.

...Художественным образам приличествует нанбольшая степень воплощевности, конкретности, жизвенной правдивости, но мудрый художник нанбольшие усилия приложит, быть может, именно к тому, чтобы, преступив грани символа, эти образы не соскочили с пьедестала эстетической изолированности и не вмешались в жизнь как однородные с нею части ее. Изображения, выдвигающиеся за плоскость рамы; натурализм живописк до „хочется взять рукой“; внешняя звукоподражательность в музыке; протокольность в поэзии и т.П., вообще всякий подмен искусства имитацией жизни - вот преступление и против жизни, и против искусства 19.

-Рамкан в пронаведения нзобразительного искусства

Особенно большое значение приобретает проблема "рамок* в живописи. Именно "рамки - будь то непосредственно обозначенные границы картины (в частности, ее рама) или специальные композиционные формы - организуют изображение и, сообственно говоря, делают его изображением, т.е. придают ему с е м и от и ч е с и й характер. Здесь можно вспомнить глубокие слова Г.К.Честертона о том, что пейзаж без рамки практически ничего не $з$ н а ч и т, но достаточно поставить какие-то границы (будь то рама, окно, арка и т.п.), как он может восприниматься как изображение ${ }^{20}$. Для того чтобы увидеть мир знаковым, необходимо (хотя и не всегда достаточно) прежде всего обозначить границы: именно границы и создают изображение. (Характерно в этой связи, что в некоторых языках «изобразить этимологически связано с «ограничить».)

Даже в тех случаях, когда границы изображения никак явно не обозначаются, сам факт наличия границ у изобрвжения тем не менее ощущается художником как естественная и неизбежная необходимость. Именно в этом смысле могут быть поняты те случаи,

${ }^{19}$ См.: Флоренский, 1922, с. $90-91$.

20 См.: Честертон, 1928, с. 152; ср. также близкие (хотя и не столь четко сформулированные) мысли в работе: Христиансен, 1909, с. 237-240. 
когда первобытный художник наносит рисунок не на чистой поверхности, а на каком-то другом изображении, не стирая его, так, как если бы это последнее изображение не было видно зрителю. Думается, художник не заботится в данном случае о том, что одно изображение смешается с другим, именно потому, что он знает, что они н е м о у т смешаться - каждое из них обладает собственным (гомогенным) художественным пространством 21 . Точно так же в китайском искусстве владелец картины или сам художник не колебались написать комментарий $к$ картине или поставить печать прямо на самом изображении (если учесть при этом, что каллиграфия считалась в Китае областью искусства, очень близкой $\kappa$ рисунку ${ }^{22}$, случай этот мало чем отличается от предыдущего примера с первобытным художником); ср. в этой связи подпись художника на европейской картине, приходящуюся опять-таки непосредственно на изображение ${ }^{23}$, а также пробы пера и вообще всевозможные записи различного содержания на древнерусских рукописных книгах 24 , в том числе и богослужебных, -

21 См. о подобных изображениях: Шапиро, 1966, с. 223 . В отличие от изложенной здесь трактовки Шапиро считает такие случаи доказательством того, что у древнего живописца вообще не было рамок.

22 См. об этом, например: Попов-Татива, 1924.

23 См.: Шапиро, 1966, с. 225.

Аналогичным образом аплодисменты и восклицания «бравоl могут звучать, например, при исполнении оперы - непосредственно во время спектакля, - ни в коей мере не вторгаясь при этом в самое действо, т.е. не нарушая представления и не препятствуя его восприятию. Подпись художника на картине и возглас чбраво! во время спектакля предстввляют собой в некотором смысле явления одного порядка: они как бы накладываются на художественный текст, но по существу не имеют к нему отношения - иначе говоря, они вне пределов художественного пространства.

24 В Паремейнике XIV в. писец Козьма приписал на полях: *...ох мне лихого сего попирия [чирия. - Б.У.], голова мя болит...»; в Прологе XIV в. писец написал: "Ох, ох, голова мя болить, не могу и псати; а уже нощь, ляз ми спати (см.: Покровский, 1916, с. 273, 363). На полях сборника слов Григория Богослова XI в. сделана искусной рукой надпись: ччьгле кривая главо пиши прямо (т.е. щегол, кривая голова, пиши прямо ); запись эта принадлежит, видимо, так называемому "нотарию", т.е. руководителю скриптория (старшему писцу) и обрацена $к$ писцу данной рукописи. В других случаях записи (различного содержания) делались владельцами книги. Ср. вообще анализ содержания приписок в работах: Соболевский, 1908; Седельников, 1927; Лихачев, 1962.

Начиная с XIV-XV вв. мы встречаем протесты против приписок на полях (см.: Панченко, 1984 , с. 106), что свидетельствует о новом эстетическом отношении $к$ книге, когда пространство основного текста постепенно перестает 
парадоксально сочетающиеся с тщательным оформлением этих рукописей и вообще с особым почитанием книги в Древней $\mathrm{Pyси}^{25}$.

Итак, *рамки " составляют чрезвычайно важный компонент живописного изображения. При этом особенно большое значение они приобретают в том случае, когда изображение строится с использованием *внутренней позиции художника́ (которая может проявляться прежде всего в применяемой художником перспективной системе или в каком-либо другом аспекте ${ }^{26}$ ).

Действительно, если живописное произведение строится с точки зрения постороннего наблюдателя ${ }^{27}$, как «вид через окно 28 , то функция «рамок» сводится к обозначению границ изображения. Между тем если живописное произведение строится с точки аре-

противопоставляться в культурном сознании маргинальному пространству приписок. Так, в январской служебной Минее XII в. из комплектв миней новгородского Софийского собора в конце рукописи в правом верхнем углу приписано почерком XIV в.: *O горе тому, кто черькает у книг по полем, на оном свете те письмена исъцьркают беси по лицю жагалом железным (см.: Горский и Невоструев, III, 2, с. 49, № 438); в ноябрьской Минее из того же комплекта находим приписку читателя XV в.: *Кто пише у книг по полем, вьси на том свете та писъмена по лицу исписати (там же, с. 34, № 436); последняя приписка тем более замечательна, что на полях әтой рукописи никаких других посторонних приписок нет.

25 В старом русском церковном богослужении (о котором мы можем судить сейчас по старообрядческой практике) замечания чисто технического хврактеја (так сказать, «мета-литургические), не относящиеся к содержанию службы, но только к порядку ее прохождения (типа: * переверни страницу и т.п.) могли произноситься не шепотом, а в полный голос - именно потому что они в принципе не могли нарушить литургического действа, по существу не имея к нему отношения. Поэтому же, в частности, неправильное произношение исправлялось (а у старообрядцев и сейчас исправляется) непосредственно во время богослужения (см.: Селищев, 1920, с. 16; Успенский, 1968, c. 111). Иначе говоря, режиссура вторгалась в само действо — но только для поверхностного наблюдателя, не сосредоточенного на его содержании (подобно тому, как в японском кукольном театре ведущие актеры не скрыты от зрителя, не будучи, однако, ими замечаемы в процессе представления).

Пс всей видимости, в еще большей степени то же было характерно для литургического действа древности - но затем литургические моменты постепенно ритуализовывались (ср., например, облачение архиерея как характерный пример такого рода).

26 См. выше, с. 173.

27 Иными словами: если позиция живописца соотносится с позицией зрителя, смотрящего на картину.

$28 \mathrm{Cp}$. в этой связи характерное обозначение рамок картины в виде оконной рамы, дверного проема и т.п., нередкое в европейском искусстве. 
ния наблюдателя, находящегося внутри изображаемого пространства 29 , то нрамки выполняют еще и другую, не менее важную функцию: обозначить переход от внешней точки зрения к точке зрения внутренней и наоборот ${ }^{30}$.

Укажем вообще, что рамки картины (и прежде всего ее рама) по необходимости принадлежат именно пространству внешнего зрителя (т.е. зрителя, смотрящего на картину и занимающего, естественно, внешнюю по отношению $к$ изображению позицию) не воображаемому трехмерному пространству, изображенному на картине $^{31}$. Когда мы мысленно входим в это воображаемое пространство, мы забываем о рамках - так же, как мы забываем о стене, на которой висит картина. (Именно поэтому, между прочим, рама картины может быть подчеркнуто декоративной и может иметь свое собственное изображение.) Рамки отмечают рубеж между внешним (по отношению к картине) миром й внутренним миром картины.

В тех случаях, когда в общем построении картины использована внутренняя точка зрения, т.е. внутренняя по отношению $k$ картине позиция художника, рамки картины обозначаются чередованием форм, соответствующих әтой внутренней позиции (в основной части изображения), с формами, соответствующими позиции внешней (на периферии изображения). Это может проявляться, например, в чередовании форм обратной перспективы с формами так называемой чусиленно-сходящейся перспективы (Niedersicht), т.e. в сочетании общей вогнутости форм в центральной части изображения (проекция вогнутости соответствует системе обратной перспективы) и подчеркнутой выпуклости форм по краям изображения (что соответствует системе перспективы «усиленно-сходящейся $)^{32}$.

При әтом важно иметь в виду, что формы усиленного схождения могут быть поняты как зеркальное отображение форм обрат-

29 Иными словами: если позиция живописца не соотносится с позицией зрителя, а противоположна ей.

30 Именно поэтому, как это иногда отмечается, древняя картина - в отличие от картины новой - в принципе не нуждается в раме, т.е. в формально очерченных границах изображения: сами формы переднего плана образуют естественные рамки картины. Древняя картина изображает не часть, механически отделенную от целого, но особым образом переорганизованное (в пределах рамок) и в себе замкнутое пространство (см. с. 260-261 наст. изд.).

31 См.: Шапиро, 1966, с. 27.

32 См.: Жегин, 1970 , с. 56-61. Ср.: Жегин, 1964, с. $185-186$. Сp. с. 260 наст. изд. 
ной перспективы. «..Формы усиленного схождения (фигуры на первом плане) даны так, как их видит зритель внутри картины (наш визави) - но, так сказать, "с изнанки“. Поскольку он должен видеть фигуры первого плана вогнутыми (в системе обратной перспективы), нам они даны выпуклыми... Эта „зеркальность“ касается лишь системы, в которой трактуются изображения, но не самих изображений... Как система первый план есть оборот второго плана ${ }^{33}$. Иначе говоря, общий замкнутый мир картины, данный, вообще говоря, с точки зрения зрителя «изнутри , у краев изображения предстает нам с оборотной, *внешней с своей стороны.

Наиболее наглядный пример сочетания точки зрения внутреннего зрителя (в центральной части изображения) с точкой зрения зрителя внешнего (на перифөрии изображевия) имеем в характерном для средневековой живописи способе передачи интерьера, когда то же здание, которое в центре картины представлено в интерьерном разрезе, по ее краям дается в экстерьерю (клл. $4,5,7$ ) - и, таким образом, мы можем одновременно видеть внутренние стены комнаты (в основной части картины) и крышу того здания, которому принадлежит эта комната (в верхней части изображения) ${ }^{34}$.

Итак, переход от внешней к внутренней зрительной позиции, Ји наоборот, - образует естественные рамки живописного произведения. В точности то же самое характерно и для произведения литературного.

\author{
Смена \\ внещпей и внутренпей \\ точек зрения \\ как формальний прнем \\ обозначения "рамок \\ латературного \\ провзведения
}

Наглядной иллюстрацией естественных рамок в литературном произведении могут служить традиционные зачины и концовки в фольклоре ${ }^{35}$.

${ }^{33}$ См.: Жегин, 1970 , с. $59-60,76$.

34 Напротив, в японской живописи с характерным для нее использованием точки зрения внешнего наблюдателя, смотрящего сверху (что иногда связывают с тем, что японский художник пишет обычно положив картину на пол, а не ставя ее перпендикулярно к земле, как это характерно для европейского искусства), интерьер здания передается qерез устранение крыши, а не через снятие передней стенки (см.: Виппер, 1922, с. 70-71; Глазер, 1908).

${ }^{35}$ См. их описание (на славянском материале) в работе: Поливка, 1927. 
В самом деле, если мы обратимся к традиционным формулам окончания сказки, мы увидим, что в большинстве случаев в них достаточно неожиданно появляется первое лицо (*я*) - при том, что сам рассказчик до этого совершенно не принимал участия в действии (то же характерно в той или иной степени и для зачинов): это появление рассказчика обыкновенно бывает как-то привязано к действию, хотя бы и достаточно условно.

Cp., например, наиболее популярную формулу, завершающую счастливый конец: ‘И я там был, мед-пиво пил, по усам текло, да в рот не попало»; или: А при смерти их остался я, мудрец; а когда умру, всяку рассказу конец и т.д. и т.п.

Казалось бы, подобного рода фразы должны бы были разрушать все предшествующее повествование - как иронией, так и введением рассказчика (ঊя), который явно не мог принимать участия в действии (особенно, если в повествовании идет речь про далекие страны или давние времена). На деле, однако, такие фразы не разрушают повествования, но заканчивают его: они необходимы именно как ко не ц сказки, заключающийся в переходе от внутренней к внешней точке зрения (от жизни сказки к повседневной жизни). В связи с переходом на иную систему восприятия очень показательно и характерное появление рифмы в коншовках такого рода ${ }^{36}$.

${ }^{36}$ Не менее характерны традиционные зачины и концовки для эпистолярного стиля, где они имеют (в особенности это относится к переписке XVIII-XIX вв.) настолько условный характер, что могут входить в определенное противоречие с содержанием письма. Действительно, вызовы на дуәль, оскорбления, негодующие письма и т.П. неизбежно заканчивались заверением в почтении и преданности. Ср. реакцию на этот обычай А.П.Сумарокова, который заключил одно из своих писем таким образом: ‘С истинным почтением имею честь быть не вам покорный слуга, потому что я чертовым слугою быть не намерен, а просто слуга Божий, Александр Сумароков* (см.: Вяземский, 1929 , с. 55).

Переход на внешнюю точку зрения в начале и конце письма вообще очень характерен для эпистолярного стиля: нередко письмо начинается с формального обращения к адресату, данного с точки зрения отправителя, и заканчивается столь же формальным наименованием отправителя, данным с точки зрения адресата; этот официальный стиль в начале и конце письма может контрастировать со свободным стилем в основной его части (так, например, обращение по имени-отчеству в начале письма может сменяться уменьшительной формой в середине и т.п.). Любопытную реакцию на этот стиль мы встречаем в письме В.Н.Каржавина к брату Е.Н.Каржавину $(1754$ г.), который подписался таким образом: “С тезоименитством твоим поздравляю брат 
Чисто композиционными задачами объясняется, например, и то, что констатация ч у д а в былине или сказке обычно бывает только в начале повествования (или нового сюжетного текста). Действительно, в фантастическом мире былины и сказки чудо, вообще говоря, не удивительно, а закономерно. Сама необычность чуда может быть констатирована только с позиции принципиально в н е ш н ей по отношению к повествованию (тогда как с точки зрения внутренней чудо совершенно естественно), - которая возможна в данном случае только в начале повествования. Отсюда характерные зачины с упоминанием чуда в эпосе - например, в сербских народных эпических песнях:

Боже правый, чудо-то какое!

Слушаите, про чудо расскажу вам!

и т.п. ${ }^{37}$

Мы приводили примеры из фольклора, но совершенно тот же принцип обнаруживается и в других видах литературы. Так, например, очень обычно - в самых разных жанрах - появдение первоге пища рассказчика (которого не было раньше) в конще повествования. В других случаях первое лицо (рассказчик) может присутствовать исключительно в начале повествования и нигде далее не встречвется (в качестве примера см. хотя бы Леди Макбет Мценского уезда Н.С.Лескова). Казалось бы, оно здесь совершенно излишне; действительно, оно не имеет никакого отношения $к$ содержанию повествования, будучи нужно единственно для рамки.

С другой стороны, в точности ту же функцию может выполнять и неожиданное обращение в конце ко в т о р м у лицу, т.е. к читатепю, от наличия которого до тех пор повествование совершенно абстрагировалось. Ср., например, традиционное обращение к принцу в којнцовке средневековой баллады (хотя бы у Вийона).

Обрацение ко второму лицу в конце повествования композиционно оправдано, в частности, когда само повествование дается с использованием первого лица. Таким образом, появление первого лица (рассказчика) в одном случае и появление второго лица (читателя) в другом случае выполняет одну и ту же роль, представляя точку зрения в н е ш н ю (позицию постороннего наблюдателя)

твой Я. (Пекарский, 1872 , с. 417). Так же может объясняться и отсутствие каких-либо зачинов и концовок в письмах Пушкина.

${ }^{37}$ См.: Неклюдов, 1969 , с. 158. 
по отношению К повествованию - при том, что само повесгвование в этих случяях дается в разной перспективе.

Появление в концовках первого лица (*я рассказчика) правомерно сравнить с появлением автопортрета художнита-надприферии картины ${ }^{38}$, появлением ведущесо у рампы (часто символизирующего автора повествования) и т.п. В то же время появление второго лица («ты зрителя или читателя) в определенных случаях можно сравнить с функцией хора в античной драме (хор может символизировать позицию зрителя, для которого разыгрывается действие); здесь можно сослаться вообще на часто ощущаемую при художественном описании необходимость какой-то фиксации позиции воспринимающего зрителя, т.е. на необходимость некоего абстрактного субъекта, с точки зрения которого описываемые явления приобретают определенное значение (становятся знаковыми) ${ }^{39}$.

Еще более явно функция рамки проявляется при переходе в конце повествования от описания в первом лице к описанию в третьем лице (см., например, नЯйтанскую дочку А.С.Пушкина, где все повествование развертывается от первого лица - от имени П.А.Гринева, - но эпилог дается от имени «издателя , где о Гриневе говорится в третьем лице). Существенно при этом, что во всех упомянутых случаях функция рамки выполняется переходом от внутренней к внешней зрительной позиции.

Говоря о значении «рамок» для в о с п р и я т и я художественного текста, можно сослаться на характерный әффект «ложного концан, т.е. на возникакщее иногда ощуцение законченуоен-новестводы, төда- ему предстоит епе быть продолженным. Можно думать, что этот эффект Возникает в том слуте, КОГда В соответствуюцем месте использован формальный композиционный

38 См. выше, с. 23 (а также илл. 1, 2).

39 В этом отношении характерны практические правила фотосъемкн, сообщаемые в әлементарных руководствах по фотографии. Так, на фотографии пейзажа, как известно, необходимо присутствие переднего плана, позволяющего реконструировать точку зрения субъекта-наблюдателя, и очень целесообразна фигура человека на переднем плане, помещаемая обычно сбоку (тогда мы смотрим с его точки зрения). Ср. тот же принцип и на старинных вндовых гравюрах (илл. 6). В противном случае описание становится безличным и тем самым может быть н е и т е р с ны м (как несоотносимое с какой-то реальной позицией). Можно сослаться в этой связи и на принципиально различное восприятие нами рассказа заведомо выдуманного или, с другой стороны, рассказа о действительных событнях: последнее придает заннтересованность, делая реальной позицию субъекта, воспринимающего данные события. 


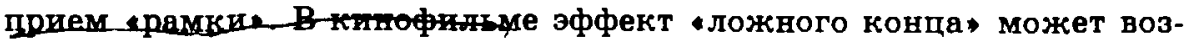
никнуть, например, при поцелуе влюбледных, соединившихся после долгой рвзлуки, поскольку сама ситуация “счастливого конда" может восприниматься как прием рамки (заметим в этой связи, что счастливы конец воспринимается как остановка действия - сp. ниже об остановке времени в функции рамки). В литературном произведении эффект рамки может возникать при всевозможных переходах на внешнюю точпу арения; особенно если әти переходы необратимы по существу сюжета - например, если гибнет преимущественный носктель авторской точки зревия. (Соответственво гибель главного героя - босителя авторской точки зрения - естественным образом воспринимается, как правило, как знак окончанця всего произведевия.)

Указанное явление - т.е. чередование внешней и внутренней точек зрения в Функции «рамок» - может быть прослежено на всех уровнях художественного произведения.

Так, в плане п с и х л о г и и очень часто принятию автором точки зрения (психологической) того или иного персонажа в начале произведения предшествует взгляд на этого же персонажа с точки зрения стороннего наблюдателя. Примеры здесь могут быть многочисленны. См., например, начало бунинского рассказа «Грамматика любви : «Н е к т о И в л е в ехал однажды в начале июня в дальний край своего уезда*. Непосредственно за этой фразой (где Ивлев описывается как человек определенно незнакомый) Ивлев сразу же становится носителем авторской точки зрения, т.е. подробно описываются его мысли и чувства и вообще весь мир дается через его восприятие. Позидии стороннего наблюдателя как не бывало: мы забываем о ней совершенно так же, как мы забываем о раме, когда смотрим на картину. Еще более разителен может быть переход от внутренвей к внешней авторской позиции в конце повествования - когда детальное описание ощущений персонажа неожиданно сменяется описанием его с точки зрения" постороннего наблюдателя - как если бы мы никогда не были с ним знакомы (ср., например, кондовку известного рассказа Джека Лондона «Любовь к жизни ).

Чрезвычайно отчетливо проявляется сформулированный принцип в плане п р ост р ан ст ве н н - в ременно́ й характеристики. В плане собственно пространственной характеристики здесь показательно, например, использование при окаймления повествования пространственной позиции с достаточно широ- 
ким кругозором, которая явно свидетельствует о зрительной позиции наблюдателя, помещенного вне действия (такой, как точка зрения «птичьего полета", «немая сцена и т.д.).

В плане характеристики временно́й не менее показательно использование в начале повествования ретроспективной точки зрения, которая затем сменяется на точку зрения синхронную. Действительно, достаточно часто произведение открывается намеком на развязку истории, которая еще не начиналась, — т.е. описанием с точки зрения принципияльно внешней по отношению к самому произведению, взглядом из будущего по отношению к внутреннему времени данного произведения. Затем повествователь может перейти на внутреннюю (по отношению к произведению) точку зрения, принимая; например, точку зрения того или иного персонажа - с характерными для этого персонажа ограничениями в знании о том, что будет дальше, - и мы забываем о предрешенности всей истории, на которую мы получили намек.

Такой зачин очень распространен в литературе самых разных эпох: так начинается, между прочим, и Евангелие от Луки (см. обращение к Феофилу).

Совершенно так же в эпилоге синхронная точка зрения, прикрепленная к какому-то персонажу, может сменяться на точку зрения всеобъемлющую (в плане времени). Ср. также характерное убыстрение (сгущение) времени в эпилоге ${ }^{40}$, связанное с широким временны́м охватом, создающим концовку повествования.

Другим приемом концовки является полная о с т н о в к а в р е м е н и. Д.С.Лихачев пишет в этой связи, что «сказка кончается констатацией наступившего „отсутствия“ событий: благополучием, смертью, свадьбой, пиром... Заключительное благополучие - это конец сказочного времени 41 .

Точно так же и неподвижная концовка „Ревизора знаменует собой остановку времени - превращение всех в позы, - которая выступает в функции рамки. С этим совпадает и выход Городничего за пределы сценического пространства - обращение его к зрителям (“Над кем смеетесь?), которых для него не существовало до этого на протяжении всего действия ${ }^{42}$. Можно сказать, что в по-

${ }^{40}$ См. об атом: Лихачев, 1967, с. 218.

41 Там же, с. $232-233$.

42 См. об этом: Лотман, 1968, с. 12, примеч. 9. Обращение к зрителям, знаменующее собой выход за пределы сценического пространства, как формальная концовка нередко встречается в театре. Достаточно напомнить конец 
следнем случае имеет место хврактерный переход из пространства внутреннего по отношению к действию в пространство внешнее по отношению к нему.

Остановка времени у Гоголя с характерным превращением персонажей в застывшие позы превращает действие в картину, живых людей - в куклы ${ }^{43}$. (Ср. в этой связи традиционный китайский театр, где в конце акта актеры замирают в специальной позе - Живой картине.)

Подобная же фиксация времени в н а ч а $\pi$ е повествования нередко передается употреблением формы несовершенного вида прошедшего времени (в глаголах речи) ${ }^{44}$. Ср., например, экспозицию «ойны и мира Толстого, где авторские введения к диалогу Анны Павловны Шерер и князя Василия начинаются с употребления формы несовершенного вида («говорила... Анна Павловна...», «отвечал... вошедший князь), которая вскоре сменяется формой совершенного вида; то же в начале гоголевского «Тараса Бульбы (см. диалог Бульбы с женой) и т.п.

Отмеченный выше принцип образования рамок художественного произведения может быть констатирован и в плане ф р а з е о о г и и. Так, анализируя гоголевские ВВечера на хуторе близ Диканьки*, Г.А.Гуковский- приходит к выводу, что «Рудый Панько как носитель речи и как образная тема исчезает из текста почти сразу после предисловия и обнаруживается отчетливо, персонально, весьма редко, в сущности, бесспорно только во введении к „Вечеру накануне Ивана Купала“, в предисловии ко второму тому сборника, во введении к „Ивану Федоровичу Шпоньке“ и, наконец, в самом конце сборника, в сказово „обыгранном“ списке опечаток. Следовательно, - заключает Г.А.Гуковский, - Рудый Панько образует только рамку книги, а в самый текст повестей не вносит свой образ ${ }^{45}$. При этом характерно, что если Рудый Панько окаймляет вообще всю книгу Вечеров на хуторе близ Диканьки , лишь спорадически появляясь в начале отдельных повестей, то в начале этих повестей может использоваться точка зрения дру-

«Недоросля Д.И.Фонвизина: фраза Стародума, указывающего на г-жу Простакову, - «от злонравия достойные плоды - конечно, обращена не столько к персонажам комедии, сколько к зрительному залу.

43 О значении театра кукол для Гоголя см.: Гиппиус, 1924; о значении живописи для Гоголя см.: Лотман, 1968.

44 О соответствующем значении этой формы см. выше, с. 98-101.

${ }^{45}$ См.: Гуковский, 1959, с. 41. 
гого рассказчика - романтически-неопределенного поэта 46 (которая затем уже сменяется точкой зрения внутренней по отношению к повествованию). Иначе говоря, речь идет об иерархии рамочного окаймления - о рамках в рамках (подробнее см. ниже).

Подобный принцип может быть констатирован в самых разнъ́х аспектах противопоставления «внешей и «внутренней авторских позиций в плане фразеологии.

Наконец, указанный принцип прослеживается и в плане и д е о л о г и и. Именно в этом смысле, в частности, могут быть поняты замечания М.М.Бахтина об "условно-литературном, условно-монологическом конце романов Достоевского, о *своеобразном конфликте между внутренней незавершенностью героев и диалога и внешней... законченностью каждого отдельного романа 47 .

\section{Составной характер художественного текста}

Мы демонстрировали тот общий случай, когда рамки всего произведения образуются при помощи смены внутренней и внешней авторских позиций. Но указанный принцип может быть отнесен не только ко всему повествованию в целом, но и к отдельным его кускам, которые в своей совокупности и составляют произведение. Иначе говоря, произведение может распадаться на целый ряд относительно замкнутых микроописаний, каждое из которых в отдельности организовано по тому же принципу, что и все произведение, т.е. имеет свою внутреннюю композицию (и, соответственно, свои особые рамки).

Мы отмечали, например, - для всего повествования в целом - характерный для обозначения рамок прием фиксации времени, выражающийся в использовании формы несовершенного вида (в глаголах речи). Но тот же прием может применяться автором для выделения какого-то куска повествования в качестве относительно самостоятельного текста, т.е. для композиционного оформления (окаймления) той или иной части повествования. Примером может служить та сцена за столом у Ростовых в “Войне и мире»,

46 См. там же, с. 40.

47 См.: Бахтин, 1963 , с. $55-56$. 
где маленькая Наташа на спор спрашивает при гостях, какое будет пирожное:

- А вот не спросишь, - го в о и л маленький брат Наташе, - а вот не спросишы

- Cпрошу, - о т в е ч а л а Наташа.

Далее при описании - так же как и раньше - употребляются только глаголы совершенного вида:

- Maмal - п р о в у ч а л по всему столу ее... голос.

Так же и дальше во всей сцене; форма несовершенного вида появляется, однако, еще однажды - а именно в ко нц е описания данной сцены:

- Нет, какое? Марья Дмитриевна, какое? - почти к р и ч л а она. - Я хочу знать! (Толстой, т. IX, c. $78-79)$.

Ср. также характерную остановку времени в конце описания сельской жизни князя Андрея:

- Mon cher, - 6 в в ло с к а ж е т входя в такую минуту княжна Марья, - Николушке нельзя нынче гулять: очень холодно.

- Ежели бы было тепло, - в такие минуты особенно сухо о т в е а $\pi$ князь Андрей своей сестре, - то он бы пошел в одной рубашке...

Княжна Марья д у м а л а в этих случаях о том, как сушит мужчин эта умственная работа (т. $X$, с. 159).

Употребленные здесь глагольные формы (имеющие вообще значение многократности действия) выражают повторяемость (неединичность) описываемой сцены на протяжении целого периода времени, подчеркивая таким образом ее типичность. Время при этом как бы перестает существовать, будучи представлено не в виде последовательно развивающегося действия, а в виде циклического повторения одного и того же. Ср. выше об остановке времени как приеме концовки всего повествования.

Подобная параллель между композиционной организацией всего произведения в целом и организацией некоторого относительно замкнутого куска повествования прослеживается и в других отношениях. 
В плане ф р а з е о л г и и это прежде всего сказывается на выборе наименований. См., например, первую фразу XXIV главы третьей части второго тома «Войны и мира»:

Обручения не было и никому не было объявлено о помолвке Бо л к о с к о го с Наташей; на этом настоял к н я ь А н д р ей (т. X, с. 228);

после этого речь идет только о ккязе Андрее; точно так же он назывался и в предыдущей главе. Совершенно очевидно, что этот единичный переход на внешнюю позицию (выражающийся в наименовании князя Андрея “Болконским») нужен автору только для того, чтобы обозначить рамки нового куска повествования.

В связи со сказанным могут быть поняты и те случаи чередования внутренней и внешней авторских позиций, о которых шла речь выше (чередование русской и французской речи в Войне и мире и т.д.). Аналогичным образом могут быть интерпретированы разнообразные случаи неожиданного появления голоса рассказчика в середине повествования.

В плане п с и Х логи и тот же принцип проявляется в уже отмечавшемся нами приеме смены внешней и внутренней психологической точки зрения, когда описанию мыслей и чувств какого-либо героя (т.е. использованию его психологической точки зрения) предшествует его объективное описание (использующее какую-то другую точку зрения). Ср., например, сцену, где раненый князь Андрей лежит на поле после Аустерлицкого сражения. Изображению его внутреннего состояния, которому посвящена вся глава, предшествует экспозиция, поквзываюпая его с внешней точки зрения:

На Праценской горе, на том самом месте, где он упал с древком знамени в руках, лежал князь Андрей Болконский, истекая кровью, и, сам не зная того, стонал тиХим, жалостным и детским стоном (т. IX, с. 355).

После этой вводной фразы все происходящее дается через восприятие героя.

Точно так же описанию внутреннего состояния Пьера на обеде в Английском клубе предшествует экспозиция, показывающая его с внешней точки зрения: *...те, которые его знали коротко, в и д е л и, что в нем произошла... перемена», “Он, к а 3 а л о с ь, не видел и не слышал ничего... и думал о чем-то одном... (т. X, с. 21). 
Иногда в данной функции выступает чья-то внутренняя точка зрения. Например, сцена в доме умирающего старого графа Безухова в «Войне и мире дается, вообще говоря, через восприятие Пьера, но в самом начале этой сцены, прежде чем перейти к описанию этого восприятия, однажды дается ссылка на восприятие А.М.Друбецкой: *Анна Михайловна... у б е д и л а с ь в том, что он спит...; непосредственно в следующей же фразе говорится: «Очнувшись, ІІьер... п о д у м а л ... (т. IX, с. 91-92). Таким образом, здесь рамку образует не внешняя, а внутренняя точка зрения (А.М.Друбецкой), но эта внутренняя точка зрения (ссылка на чье-то восприятие) нужна автору не сама по себе, но лишь постольку, поскольку она является внешней по отношению к Пьеру, выступающему в данной сцене как центральная фигура повествования. Тем самым и в таких случаях мы вправе считать, что рамка образуется переходом от внешней к внутренней точке зрения.

Итак, общий текст всего повествования может последовательно распадаться на совокупность все более и более мелких микроописаний, каждое из которых организовано по одному и тому же принципу (т.е. имеет специальные рамки, обозначенные сменой внешней и внутренней авторских позиций) ${ }^{48}$.

Укажем, что тот же принцип прослеживается и в организации пространства в довозрожденческой живописи (использующей точку зрения "внутреннего зрителя) ${ }^{49}$. Общее пространство картины распадается здесь на совокупность дискретных микропространств (илл. 8), каждое из которых организовано таким же образом, что и все изображаемое пространство в целом, т.е. имеет свой передний план, отвечающий зрительной позиции внешнего наблюдателя (зрителя картины), тогда как само микропространство организовано с использованием позиции внутреннего наблюдателя (зрителя изображаемого пространства, который находится в самом

48 Напомним, что в отношении организации времени мы уже отмечали подобный принцип при рассмотрении әтой проблемы в главе третьей: время может быть представлено в произведении в виде отдельных (дискретных) сцен, каждая из которых дается с точки зрения синхронного наблюдателя, характеризуясь своим специальным микровременем (см. с. 97). Очевидно, что в том случае, когда пространство или время представлено в виде дискретных кусков, рамки появляются на стыке этих кусков, отмечая переход между ними.

49 См.: Жегин, 1970. В наиболее схематизированной форме этот принцип представлен, конечно, в древнем египетском искусстве. Ср. передачу пространства здесь в виде расположенных друг под другом рядов. 
этом пространстве). На это указывают, например, характерные чередования форм усиленно-сходящейся и обратной перспективы (как уже говорилось, первые появляются, вообще говоря, на периферии изображения, тогда как само изображение строится - при использовании внутренней позиции зрителя - в системе обратной перспективы); чередование затененных и освещенных пластов (при внутреннем источнике света, характерном для данной живописной системы, затенение появляется, вообще говоря, на периферии изображения) и т.П. Указанные чередования при этом могут иметь место как в горизонтальном или вертикальном направлении, так и в глубину картины, придавая тем самым пространственной системе древнего изображения характерный слоистый характер. Эта слоистость пространства в древней живописной системе отчетливо обнаруживается как в так называемых «иконных горках - традиционном ландшафте изображения, - так и, между прочим, в прерванных изображениях ангельских фигур, небесных светил и т.П., когда одна часть изображения скрыта за следующим пространственным пластом ${ }^{50}$.

В отношении литературы мы можем рассматривать приведенные случаи объединения текстов более мелкого порядка (микроописаний) в общем тексте всего повествования как п о в с т ь В П о в е т и. В наиболее наглядном и тривиальном случве этот принцип организации проявляется в виде вставных новелл, обрамленной повести и т.д. и т.п.; в этом случае смена рассказчиков в произведении дана эксплицитно, и границы между отдельными новеллами отчетливо осознаются читателем. В другом случае который мы только что рассмотрели - отдельные микроописания органически слиты в объединяющем их произведении; изменение позиции рассказчика здесь скрыто от читателя, и границы между соответствующими кусками текста прослеживаются лишь в виде внутренних композиционных приемов организации каждого отдельного куска, т.е. в виде особых «рамок (образующих как бы внутренние швы произведения): Существенно, что в последнем случае это слияние н е а с ч л н и м о, т.е. произведение само собой не распадается на составляюшие части.

Заметим к тому же, что возможна сложная композиция, когда различные микроописания наслаиваются одно на другое при подобного рода слиянии, т.е. внутренние композиционные рамки на одном уровне (скажем, в плане фразеологии) не совпадают с рамками,

${ }^{50}$ См.: Жегин, 1970, с. 84-85. Ср. Жегин, 1964; Жегин; 1965. 
проявляющимися на другом уровне (например, в плане пространственно-временно́й характеристики). Понятно, что при такой организации текста повествование никак не может быть расчленено на составляющие микроописания, хотя последние и могут быть констатированы в его составе на том или ином уровне. В то же время в случае вставных новелл граниды составляющих новелл, естественно, совпадают на всех уровнях.

Точно так же, например, $р$ е ч в в $р$ е ч и может быть представлена в виде п р м о й р еч и, вставленной в бо́льший отрезок текста (здесь тот же принцип организации текста, что и в случае вставных новелл), - или же органически сливаться с объединяющим ее текстом, как в случае несобствен ноп р м о й ре ч и.

Совершеннс аналогично в отношении изобразительного искусства мы можем считать, что имеем дело с и зобр аже н и м в и 3 о 6 р а ж е н и и. В наиболее тривиальной форме подобная иерархическая организация представлена в случае изображения картины в картине (а также объединения клейм в иконе, фресок в стенных росписях и т.п.).

В то же время слоистую организацию пространства в средневековой живописи можно рассматривать как тот случай, когда отдельные изображения, представляющие отдельные микропространства, органически (нерасчленимо) сливаются воедино в общем пространстве, изобряжяемом в живописном произведении, - так, что границы между составляющими микропространствами прослеживаются лишь в виде внутренних композиционных рамок.

«Изображение в изображении (и вообще - «произведение в произведении ) может использоваться в специальной композиционной функции, но этот вопрос мы рассмотрим в нижеследующем разделе.

\section{Некоторые принципы изображения •фона •}

Если рассматривать общее пространство живописного произведения как составленное из совокупности отдельных пространств, то можно указать еще на одно обстоятельство, характерное для старой живописи: различные составляющие пространства здесь могут быть организованы по-разному в зависимости от их места и 
функции в изображении, т.е. трактоваться в разных художественных системах (подчиняясь соответственно специфическим для каждой системы принципам организации).

Укажем в этой связи, что фон в средневековой живописи нередко дается в иной художественной системе, нежели фигуры на основном плане. Иногда, например, фон в противопоставление фигурам основного плана дается в перспективе «птичьег полета (нлл. 9).

Здесь возможна прямая параллель с композицией литературного произведения. Подобно тому как фон в живописном произведении может контрастировать с фигурами основного плана, будучи дан с принципиально иной точки зрения - а именно с точки зрения гораздо более поднятой, - точно так же и в литературном произведении, как мы уже отмечали ${ }^{51}$, всеобъемлющее описание с достаточно приподнятой зрительной позиции может композиционно противостоять более детализированному описанию с других, более специальных точек зрения. Характерно, что как в том, так и в другом случае точка зрения "птичьего полета появляется на периферии изображения ${ }^{52}$.

Можно указать также и на характерный прием сочетания *перспея:тивного (т.е. построенного по правилам классической линейной перспективы) и “неперспективного изображения для противопоставления разных планов в живописном произведении ${ }^{53}$ (клл. 10-12) - например, когда плоскостная декоративность фона (изображенного с соблюдением правил линейной перспективы) противостоит объемности фигур на основном плане - что может быть сопоставлено с эффектом сочетания живых актеров на фоне декорации $^{54}$. Ср. также нередкую противопоставленность лаконичности жеста и общей фронтальности изображения на основном

51 См. выше, с. 89 наст. изд.

52 Фон, конечно, принадлежит именно периферии изображения - см. об этом ниже.

53 В этой связи характерно изображение интерьера в виде разрезанного здания с устраненной передней стеной (в XVII веке в России, в XIII-XIV в Италии), причем внутренний вид разрабатывается перспективно (см.: Михайловский и Пуришев, 1941, с. 121), представляя собой таким образом как бы своего рода картину в картине.

54 Можно сослаться в этой связи на характерное для живописи гваттроченто изображенге обнаженной модели (на основном плане картины) на фоне архитектурных декораций, которые трактуются в системе линейной перспективы. 
плане картины и подчеркнуто резких ракурсов при изображении фигур на ее фоне (т.е. фигур, играющих роль єстатистов») (илл. 13) ${ }^{55}$.

В эпоху Возрождения общее изображаемое пространство нередко строится в виде изображения вескольких микропространств, каждое из которых, будучи построено по закономерностям прямой перспективы, имеет самостоятельную перспективную организацию (т.е. свою особую линию горизонта ${ }^{56}$ ). При этом пространство на заднем плане бывает окаймлено в виде дверного проема или оконной рамы и т.п. - т.е. имеет свои специальные фрамки (см. выше об использовании подобных приемов при обозначении рамок в связи с характерным пониманием картины после Возрождения как -вида через окно ${ }^{57}$ ). Таких последовательно изображенных пространственных слоев (каждый из которых имеет особые рамки и особую перспективную позицию) может быть и несколько в картине ${ }^{58}$.

Таким образом, очень часто изображение фона в живописном произведении может быть понято как своего рода к а р т и н а в К а р т и н е, т.е. самостоятельное изображение, построенное по своим специальным закономерностям (влл. 16-18). При этом изображение фона в большей степени, чем изображение фигур на основном плане, подчиняется чисто декоративным задачам ${ }^{59}$, мож-

55 В связь с этим может быть поставлено и то обстоятельство, что главные . фигуры в иконах трактуются фронталько, тогда как второстепенные могут даваться в профиль, с. 275-276 наст. изд.

56 Линия горизонта опғе́деляется как линия, на которой сходятся параллельные линии при перспективном изображении.

${ }^{57}$ См. с. 179 . Ср. также с. 259 и сл. наст. изд.

58 В качестве примера можно сослаться на :Благовещение Боттичелли, на полотна Й. ван Клеве (илл. 14) и т.П. См. особенно Мадонну с младенцем и апостолом Фомой работы мастера из Гроссгмайна (илл. 15).

59 Этим может быть объяснено то любопытное обстоятельство, что при изображении фока - и вообе на периферии картины - в старой живопнси нередко появляются әлементы художественной системы, более продвинутой в эволюционном отношении, нежели система, применяемая при изображении основного плана (см.: Шапиро, 1953, с. 293). Иначе говоря, при изображении фона и вообще фигур, имеющих вспомогательное значение для самой картины, художник может опережать свое время; так, фон может строиться по закономерностям прямой (линейной) перспективы, по принципам барокко (с типичными здесь ракурсами и выразительной мимикой) и т.П. - в то время, когда соответствующая художественная система еще не занимает господству. ющего места в искусстве.

Действительно, формы прямой перспективы и формы барокко ориентированы именно на внешнего зрителя, непосредственно завися от пространствен- 
но сказать, что здесь часто изображается не самый мир, но декорация этого мира, т.е. представлено не само изображение, а изображение этого изображения.

Это связано с тем, что изображение фона, как относящееся к п е $р$ и ф е р и и картины, ориентировано на внешнюю зрительную позицию (т.е. позицию постороннего наблюдателя), тогда как изображение основного плана ориентировано в довозрожденческой живописи на позицию внутреннего зрителя, воображаемого в центре картины (см. об этом выте). В отношении того, что фон в древней живописи изображался не с внутренней, а с внешней точки зрения, можно сослаться на характерный способ передачи интерьера в русских иконах, когда здание, внутри которого происходит действие и которое служит соответственно фоном для последнего, - изображается со своей в н е ш н е й, а не с внутренней стороны (илл. 19) ${ }^{60}$.

О единых приемах изображения фона и рамок произведения см. также ниже.

Здесь можно сослаться, например, на откровенно декорационный фон (илл. 20) в живописи Джотто (так, рассматривая зависимость пейзажа Джотто от мистериальных декораций, А.Бенуа говорит о "бутафорских домиках и павильонах на изображаемом у Джотто ландшафте, о «кулисообразных, плоских, точно из картона вырезанных скалах ${ }^{61}$ ) или на приемы работы у Тинторетто или Эль Греко, которые организовали фон, подвешивая к потолку восковые фигурки, изображая тем самым не самое действительность, но изображение этой действительности ${ }^{62}$.

ной и временно́й позиции последнего (отсюда - неизбежный субъективизм такого изображения): естественно, что подобную ориентацию можно ожидать именно на периферии живописного произведения.

Укажем в этой связи, что закономерности прямой перспективы были известны с достаточно давнего времени (по-видимому, с V в. до н.э.), но применение их ограничивалось прикладными задачами; прежде всего они применялись при изображении театральных декораций (показательно, что само открытие прямой перспективы было связано с театральным декорационным искусством - скенографией *, ср. ниже с. 293 наст. изд.). Есть основания полагать, что и в эпоху Возрождения применение в живописи прямой перспективы первоначально было также связано с театром (такая связь иногда отмечается, например, в отношении пейзажей Джотто). См. ко всему сказанному: Успенский, 1970, с. 10-11.

60 См. 06 этом: Успенский, 1965, с. 254; см. также с. 284 и сл. наст. изд.

61 См.: Бенуа, I, вып. 1, с. 107-108.

62 См.: Флоренский, 1967, с. 396-397; Каптерева, 1965, с. 5, 31. 
Заметим при этом, что «изображение в изображении в большинстве случвев строится в иной художественной системе, нежели та, что применяется вообще в картине. Так, например, для искусства майя характерна, вообще говоря, профильность изображения лица (аналогично тому, как это имеет место в древнем египетском искусстве); но в тех случаях, когда изображается маска или какая-то скульптура, т.е. в случае «изображения в изображении она может изображаться en face. То же замечание, по-видимому, может быть отнесено к египетскому искусству - если говорить о трактовке лица ${ }^{63}$. Что же касается трактовки всей человеческой фигуры в искусстве Египта, то и в этом случае изображение статуи или мумии строится принципиально иначе, чем изображение живого человека: если последнее дается обычно в виде характерного совмещения фаса и профиля (т.е. имеет место передача характеристик изображаемой фигуры в трехмерном пространстве), то первое дается в чистом профиле (т.е. трактуется в двумерном пространстве) $)^{64}$. Аналогичное противопоставление фронтального и профильного изображения лица прослеживается и в греческом искусстве (прежде всего в вазовой живописи) ${ }^{65}$. Наконец, и в русской

63 См. роспись на саркофаге из Керчи (Гос. Эрмитаж), изображаюшую мастерскую египетского художника (см. репродукцию в кн.: Павлов, 1967, табл. 26): показателен контраст между профильным изображением художника и фасовым изображением на картинах, висящих на стенах. Ср. также объяснение фасового изображения демона Беса в египетском искусстве именно тем, что лицо Беса изображалось как маска: Виппер, 1922, с. 61 (примеч. 2), 64 (примеч. 3).

Можно предположить, что возникновение фасового портрета в египетском искусстве первоначально вообще было связано с изображением изображения (погребальной маски), а не непосредственно самого человека. Действительно, первоначальной функцией портрета в Египте было заменять погребальную маску: портрет вставлялся в мумию на тех же правах, что и маска, и долгое время сосуществовал с ней (см. об этом: Павлов, 1967, с. 46, passim). Надо полагать, что сначала копировалась именно маска и уже потом фасовое изображение отделилось от мумии и стало функционировать самостоятельно.

Полную аналогию к сказанному можно усмотреть в әволюции натюрморта. В самом деле, изображение целых предметов наблюдается впервые в искусстве бронзового века в виде оружия, изображаемого на саркофагах и сакральных памятниках, причем изображенное оружие как бы служит в этих случаях заменой реального, положенного на крышку гробницы (см.: Виппер, 1922, с. 53, примеч. 1).

64 См.: Мальмберг, 1915, с. 15-16 и особенно примеч. 38.

65 Ср.: Шапиро, 1973, с. 40, 44, 61 (примеч. 89); предлагаемая нами интерпретация не совпадает с объяснением Шапиро. 
иконописи определенные фигуры, как правило, трактуются в профиль - скажем, фигура коня обыкновенно дается в виде стилизованного профильного изображения, как бы распластанного на плоскости, - но эта закономерность нарушается в том случае, когда изображается не непосредственно конь, а его статуя (ср. фасовое изображение коня в статуе Юстиниана на иконе Покрова XVI века новгородских писем ${ }^{66}$ ). Во всех этих случаях, таким образом, изображение изображения предмета трактуется прямо противоположным образом по отношению к тому, как был бы изображен сам этот предмет ${ }^{67}$.

Итак, фон в картине (и вообще ее периферия) может передаваться каким-то специальным образом - как *изображение в изображении . Соответствующим образом в картине могут формально выделяться фигуры, относящиеся к фону изображения, и вообще всевозможные второстепенные фигуры - фигуры, играющие роль *статистов 68 .

Но точно так же и в литературе сстатисты , появляющиеся, так сказать, на заднем плане повествования, обычно изображаются

66 См.: Некрасов, 1926, с. $12-13$ и табл. I, рис. 1.

67 Такого же рода противопоставление может наблюдаться и при изображении мертвых. Как отмечает Б.Р.Виппер, мертвые тела изображаются в египетском искусстве теми же приемами, что и статуи (см.: Виппер, 1922, с. 60-61; ср.: Шапиро, 1973, с. 43-44). Совершенно так же в греческой вазовой живописи при общей профильности изображения мертвые тела могут даваться еп fасе и в резком ракурсе (см.: Виппер, 1922, с. 94-95; ср. также с. 61 и с. 95, примеч. 1).

Между тем, в русской иконописи при общей фронтальности изображения мертвые тела, напротив, могут быть показаны в профиль. Такова икона -Усекновение главы Иовнна Предтечи XVI в. из Стариц (собрание Третьяковской галереи): отрубленная голова Иоанна, лежащая на подносе, изображена в профиль. Это тем более показательно, что профильное изображение святых, вообще товоря, не допускается в иконописи (см. с. 275 и сл. наст. изд.).

Можно полагать вообще, что мертвое тело по своей семантике относилось в сознании художника к фону, к «декорациям - и, гоответственно, изображалось по законам изображения последних. Отсюда проблема изображения *натюрморта*, т.е. мертвой природы, связана с проблемой «изображения в изображении . Ср. о связи ракурса с изображением мертвого тела: Виппер, 1922 , с. 61,95 ; Рате, 1938 , с. $15-16$.

68 В отношения связи фона (декораций) и “статистов характерен способ перемены декораций в шекспировском театре - когда реквизит вносили и уносили сами действующие лица (второстепенные персонажи), см.: Аникст, 1965 , с. 146. Ср. аналогичную функцию униформистов в современном цирке, 
с применением композиционных приемов, в принципе противоположных тем, которые используются при описании героев данного произведения: если герои могут выступать носителями авторской точки зрения (в том или ином аспекте), то статистам, вообще говоря, не свойственно выступать в этой функции, их поведение дается обычно в плане подчеркнуто внешнего описания. В наиболее характерных случаях сстатисты описываются не как люди, а как куклы, т.е. имеет место тот же прием иизображения в изображении , что был только что отмечен для живописи ${ }^{69}$.

В качестве примера можно сослаться на описание *жильцов в «Превращении Ф.Кафки. Эти персонажи являются типичными статистами, они появляются всегда на заднем плане действия. И характерно, что они описываются именно как куклы - это сказывается прежде всего в подчеркнутом автоматизме их поведения. Поведение их совершенно одинаково, они всегда появляются вместе и даже в одном и том же порядке (показательно, что один из них называется «средним - так, как если бы они никогда не меняли своей относительной позиции), их движения предельно автоматизированы. Обычно описываются только их жесты; характерно при этом, что говорить вообе может только один из них («средний ), который и представляет, таким образом, их всех. Можно сказать, что жильцы у Кафки предстают в виде единого механизма из трех частей - как бы в виде трех соединенных между собой кукол, которыми управляет один актер.

Пример специального подчеркивания автоматизма в поведении персонажей на фоне (описание статистов как кукол, механически организованных по принципу сообщающихся сосудов) находим и у Толстого в *Войне и мире»; дается описание блондинки, за которой ухаживает Николай в Воронеже, и ее мужа:

К концу вечера... по мере того, как лицо жены становилось все румянее и оживленнее, лицо ее мужа становилось все грустнее и солиднее, как будто доля оживления была одна на обоих, и по мере того, кақ она увеличивалась в жене, она уменьшалась в муже (т. XII, с. 18).

В качестве самоочевидной иллюстрации можно, наконец, привести и описание вечера у Анны Павловны Шерер (открывающее повест-

69 Вообще об изображении персонажей по принципу кукол - безотносительно к функции данных персонажей в произведении - см.: Гиппиус, 1966. 
вование в «Войне и мире»), где автоматизм поведения персонажей на фоне повествования подчеркивается специальным авторским сравнением с веретенами, запущенными в прядильной мастерской.

Еще более знаменательно в этом смысле описание толпы у Достоевского в «Дневнике писателя*: «Кто-то гримасничал передо мною, спрятавшись за всю эту фантастическую толпу и передергивая какие-то нитки, пружинки, и куколки эти двигались, а он хохотал и все хохоталl («Петербургские сновидения...* - Достоевский, т. XIX, с. 71).

Так же, т.е. по принципу кукольного театра, описывается Достоевским и семейство Капернаумовых в «Преступлении и наказании * (у которых квартирует Соня Мармеладова). Капернаумовы это типичные *статисты*, они не произносят в произведении ни одного слова. См., например, разговор Свидригайлова с Капернаумовой, который изображается так, как изображался бы разговор по телефону: мы слышим голос только одного Свидригайлова.

- Видите, вот тут вход к Софье Семеновне, смотрите, нет никого! Не верите? Спросите у Капернаумова; она им ключ отдает. Вот и она сама madame de Капернаумов, a? Что? (она глуха немного) ушла? Куда? Ну вот, слышали теперь? Нет ее и не будет до глубокого, может быть, вечера (Достоевский, т. VI, с. 373).

Свидригайлов разговаривает с Капернаумовой так, как он разговаривал бы с куклой, - сам за нее отвечая.

К вышесказанному можно заметить, что действующие лица в произведении нередко делятся на подвижные и неподвижные; последние не могут менять своего окружения, т.е. прикреплены к какому-то определенному месту, тогда как первые свободно меняют окружение. Естественно, что в роли подвижных фигур выступают обычно центральные фигуры повествования, а в роли фигур неподвижных свойственно выступать разного рода второстепенным персонажам ${ }^{70}$. Таким образом, «статисты могут быть локально закреплены за данным окружением, они прикреплены к фону, составляя его неотъемлемую принадлежность: описание фона необходимо включает в себя и описание статистов такого рода. Типологи-

${ }^{70}$ См.: Неклюдов, 1966, с. 42. Ср.: Лотман, 1966, с. 464. 
чески аналогичный принцип может быть отмечен и в отношении театра 71 .

Подобное же возрастание условности на фоне повествования может проявляться и в н а и м е н в а н и и эпизодических фигур. Так, например, в рассказе Катерины Ивановны в •Преступлении и наказании Достоевского неожиданно появляются совершенно неправдоподобные и условно-гротескные фамилии - княгиня Безземельная , «князь Щегольской и т.п. (т. VI, с. 139) - при том, что вообще фамилии героев в этом произведении по большей части не отличаются условностью. Таким образом, здесь имеет место резкая смена принципов описания: от реалистического к подчеркнуто условному. Но существенно, что этот рассказ своего рода про из ведение в п рои з в де ни и и что эти фигуры не принимают участия в действии, т.е. как бы не существуют *на самом деле (на переднем плане повествования), но появляются только в рассказе Катерины Ивановны. Соответственно и даются они приемом *изображения в изображении .

Возрастание условности при наяменовании эпизодических фигур (появляющихся на фоне повествования) прослеживвется у Достоевского в целом ряде произведений. Ср. такие случаи, как «рафиня Залихватская («Дядошкин сон ), Дурь-Зажигины («Игрок»), *князь Свинчаткин (*Двойник»), «учитель Дарданелов», *гимназист Булкин („Братья Карамазовы ), студент - материалист и атеист - Кислородов («Идиот ), «генерал Русопетов ( Село Степанчиково ), «солдатка Скапидарова (*Крокодил»), “сочинитель Ратазяев ( Бедные люди ). Особенно показательно откровенное обнажение приема в наименовании эпизодических фигур или второстепен: ных персонажей у Достоевского - ср.: ‘писарь Писаренко («Господин Прохарчин ), «медик Костоправов ( Честный вор ), 一 которое может даже специально подчеркиваться автором: содержатель игорного дома, в котором Подросток выигрывает на зеро, называется Зерщиков (^Подросток॰), о Трусоцком (^Вечный муж») автор пишет, что он в доме Захлебиных « р у с и л вслед за всеми, о Разу-

71 В отношении театра характерны, с одной стороны, элементы пантомимы на заднем плане в старинном театральном действии и, с другой стороны, резкое усиление условности при изображении ссцены на сцене. Вообще о приеме сцены на сцене см.: Боас, 1927.

Ср. также маски в античном театре, которые появляются только у исполнителей характерных ролей - старика, плута и т.п. (об этом можно судить по изображению театрального представления в помпейской живописи или на иллюстрациях в рукописях Теренция). 
михине («Преступление и наказание ) говорится, что тот «р а с с у д и т е л в н ы й, что и фамилия его показывает и т.д. и т.л. ${ }^{72}$

Таким образом, при изображении фона (и фигур на фоне) как в изобразительном искусстве, так и в литературе может применяться один и тот же прием изображения в изображении . Иначе говоря, здесь имеет место усиление знаковости описания (изображения): описание представляет собой не 3 н а к изображаемой действительности (как в случае центральных фигур), а знак знака действительности. Можно сказать также, что в этом случае имеет место усиление условности описания ${ }^{73}$. Соответственио центральные фигуры (фигуры на основном плане) противопоставляются фигурам второстепенным по принцйт оти ое тельно меньше й Знаковости (условности) их описания. Это может быть понято в том смысле, что относительно меньШая знаковость естественно ассоциируется с б о л ш ш й р е а л и с т и н о с т ь (правдоподобностью) описания: центральные фигуры противопоставляются второстепенным как менее знаковые (условные) и, следовательно, более близкие к жизни ${ }^{74}$ :

72 Отмечено А.Бемом (см.: Бем, 1933, с. 417-423). Отмечая подобные случаи, Бем, однако, не связывает наименования такого рода с функцией персонажа в произведении, но указывает, что они должны были неизбежно восприниматься на фоне поэтики •натуральной школы॰, представляя собой ‘гоголевское наследие, продолжающее определенную традициюь; понятно, между тем, что использование предшествующей традиции более всего проявляется именно на фоне повествования. Материал для аналогичных примеров можно найти в работе того же автора „Словарь личных имен у Достоевского : Бем, 1933a.

Особенно знаменательно, что Достоевский в Униженных и оскорбленных с сам заставляет Маслобоева в порыве раздражения против аристократии сочинять фамилии такого типа: «барон Помойкин, граф Бутылкин , «граф Барабанов (ср.: Бем, 1933, с. 422); ср. еще выражение: ялежу себе как эдакой граф Бутылкин в речи пьяного арестанта •Записок из мертвого дома (Достоевский, т. IV, с. 115). Мы видим, опять-таки, что подобный прием закономерно появляется в случае ‘изображения в изображении .

73 См.: Успенский, 1962, с. 127 , где условность определяется через понятие знака как ситуация ссылки на выражение, а не на содержание, и ставится вопрос о мере условности (определяемой по порядку компонентов в последовательности: знак знака знака... и т.д.).

74 Аналогичное явление можно проследить и для кино. См. хотя бы усиление условности в кино в случае «рассказа в рассказе», который нередко дается, например, с использованием приемов немого кино. 
Применительно к средневековой живописи подобное возрастание условности на фоне живописного произведения и вообще в менее важных его частях легко показать, сославшись на характерную о р н а м е т а л и з а и г в функционально менее важных частях изображения. Ср., например, традиционное для фона древней иконы изображение пеизажа в виде так называемых иконных горок (которое может переходить в откровенны условны орнамент) или же подчеркнуто орвамевтализованвое изображение складок на одежде (так называемых -пробеловь) в иконе (илл. 21-24). В иконе это возрастание условности в наименее значимых частях изображения выражается, между прочим, еще и в том, что соответствующие части (фон, одежда) закрываются специальным о к л а д о м, на котором нанесено нарочито условное изображение и который представляет собой, таким образом, своего рода ‘изображение в изображенин 75 .

Аналогично могут быть поняты упомянутые выше случаи появления на перпферии изображения относительно резких ракурсов и элементов прямой перспективы ${ }^{76}$. Можно думать, что соответствующие формы воспринимались в свое время как условные, подобно тому как сейчас мы склонны трактовать как условность строго фронтальные формы ${ }^{77}$ и элементы обратной перспективы.

Не менее характерно и символическое изображение атрибутов фона в древней иконе и миниатюре. Например, ночь может изображаться здесь в виде свитка со звездами, рассвет в виде петуха и т.п. (илл. 25) ${ }^{78}$; ср. также аллегорическое изображение реки в виде струи, льющейся из кувшнна, который держат человеческие фигу-

75 Так же может трактоваться и условный орнамент на полях старой русской иконы. Поясняя возникновение этого орнамента, А.И.Анисимов писал, что древнейшие иконы украшались драгоценными камнями, врезавшимися непосредственно в левкас или в холст, в поля иконы или в изображение нимба. «а неимением этих дорогостоящих материалов, художник традиционно воспроизводил в краске тот рисунок и цвет, которые стали для него привычными атрибутами в применении к украшению иконы (см.: Анисимов, 1928, с. 178). Мы видим, что условный орнамент здесь непосредственно связан с «изображением в изображении .

76 См. с. $194-195$ наст. изд.

77 Характерным образом Ф.И.Буслаев считал, что « древне-христианской живописи преобладает начало скульптурноеь, т.е. что в иконах изображались как бы не сами фигуры, но скульптурные представления этих фигур (см.: Буслаев, 1910, с. 204). Это вполне согласуется со взглядом Буслаева на иконы как на условное искусство - откуда и следует естественное стремление рассматривать иконописное изображение как построенное по принципу «изображения в изображении .

${ }^{78}$ Cp. с. 238 наст. изд. 
ры, изображение ада в виде лица на заднем плане, и т.д. и т.п. (см. илл. 26-29). Очевидно, что восприятие изображения додобного рода предполагает дополнительную перекодировку смыслов на более высоком уровне (по сравнению с несимволическими изображениями). Таким образом, и в әтом случае имеет место возрастание условности (с характерным уъеличением дистандии между обозначаемым и обозначающим) на фоне изображения. Можно сказать, таким образом, что декорации, на фоне которых происходит действие, изображаются в этих случаях подчеркнуто условно. Условный фон предстает здесь как своеобразная идеограмма.

В этой связи нельзя не вспомнить об условном изображении декорации в виде простых табличек с обознячением места действия на шекспировской (и, во всяком случае, дошекспировской) сцене. По сути дела от этого мало отличается и более поздний холст с условным изображением декорации. Сама условность декорации как бы оттеняет действие на сцене, делая его более жизненным.

Может быть, именно театр с характерным для него сочетанием актеров и декоряций (которые образуют фон действия, представляя собой изображение в изображении) в какой-то степени оказал влияние на литературу и изобразительное искусство, обусловив те явления, о которых только что шла речь ${ }^{79}$.

\section{Единство принципов обозначения фона и рамок}

Чрезвычайно характерна общность формальных приемов при изображении фона и рамок художественного произведения - общность, которая прослеживается в самых разных видах искусства. Так, в старинном театре элементы пантомимы, с одной стороны, были характерны для заднего плана действия, а с другой стороны, нередко служили введением в спектакль (ср. пантомиму в начале действия в старинном представлении «Убийство Гонзаго , изображенном в шекспировском «Гамлете $)^{80}$. В довозрожденческой живописи эта общность может проявляться, например, в единстве

79 О влиянии театра на живопись вообще писалось довольно много. См. прежде всего: Маль, 1908; Коген, 1943; Франкастель, 1965, с. 213 и сл.; Кернодль, 1945.

80 О пантомиме в начале спектакля см.: Аникст, 1965, с. 289. 
перспективных приемов, применяемых на фоне и по краям изображения (которые могут быть противопоставлены между тем перспективной системе, применяемой на основном плане центральной части картины), в резких ракурсах, появляющихся в том и в другом случае, и т.п. Та же общность может быть обнаружена и в литературном произведении - через противопоставление внешнего описания (характерного как для фона, так и для рамок повествования) описанию внутреннему.

Общность эта, конечно, никак не случайна. Как мы уже неоднократно отмечали, фон, точно так же, как и рамки, принадлежит п е $\mathrm{p}$ и ф е $\mathrm{p}$ и и изображения (или описания). Соответственно, если рассматривать произведение как замкнутую в себе систему, то и в случае рамок, и в случае фона правомерно ожидать внешнюю, а не внутреннюю зрительную позицию. Задний план изображения выполняет в общем ту же функцию, что и его передний план (проявляющийся по краям изображения): оба плана прежде всего противопоставлены тому, что имеет место в н у т р и изображения, т.е. в его центре. Можно думать, что то, что представлено н а Ф о н е какой-то центральной изображаемой фигуры, в равной мере может мыслиться представленным и в п е р д и нее, - но не изображается здесь только потому, что тогда это изображение, менее важное по самому своему существу, закрыло бы самое фигуру. С другой стороны, то, что на самом деле находится в п е ре д и изображения в ряде случаев может быть вынесено средневековым живописцем н а ф о н этого изображения - отчасти, возможно, и с той целью, чтобы не заслонялось главное изображение (ср. упоминавшийся уже способ передачи интерьера, когда изображение здания, в котором происходит действие, выносится на фон этого действия). Изображение фона во многих случаях может быть понято как зеркальность переднего плана (или как +просвечивающий" первый план).

Помимо того нередко рамки произведения бывают устроены таким образом, что последнее строится как п р о и з в д е н и е в П р о и з в д е н и (картина в картине, театр в театре, новелла в новелле). Таким образом, рамки обозначаются здесь тем же общим способом, что и фон, хотя внутри этого единого принципа ситуация в данном случае прямо обратная. Если в рассмотренном выше случае приемом «изображения в изображении" обозначается фон произведения, причем изображение, помещенное внутри другого изображения, предстает как более условное по отноше- 
нию к этому последнему (окаймляющему изображению), - то в данном случае изображение, помещенное в другое изображение является, напротив, основным (представляет собой центр композиции), тогда как окаймляющее изображение выступает на периферии, играя роль рамок. Соответственно в последнем случае внешнее (окаймляющее) изображение дается как более условное, по сравнению с которым внутреннее (центральное) изображение выступает как более естественное.

В отношении живописи здесь можно сослаться на изображение раздвинутых завес, окаймляющих картину (ср. „Сикстинскую мадонну Рафаэля) или на нередкое изображение по краям картины оконной рамы или дверного проема - вообще того или иного экстерьера (см. выше).

В отношении театра очень характерны те прологи, которые изображают беседу зрителя или актеров (на сцене) перед началом спектакля (ср., между прочим, театральное вступление в „Фаусте•) - и таким образом центральное действие предстает в виде сцены на сцене.

Что же касается литературы, то здесь можно сослаться на частый прием обрамления новеллы вводным эпизодом, который не имеет отношения к самому действию, но по отношению к которому данная новелла предстает как вставная (ср. «Книгу тысячи и одной ночи *, «Декамерон • и т.п.).

Понятно, что при подобном способе построения рамок произведения - в виде дополнительного обрамляющего произведения, включающего в себя данное (центральное) произведение, - закономерно применение внешней точки зрения именно $\kappa$ обрамляющему произведению, выполняющему роль рамки. Внешняя точка зрения, с одной стороны, непосредственно корреспондирует с точкой зрения зрителя или читателя и, с другой стороны, характеризуется подчеркнутой иллюзионистичностью (декоративностью, условностью), которая может оттенять центральное произведение, делая его более жизненным.

В связи со сказанным можно интерпретировать всевозможные колебания степени условности в произедении. Разнообразные всплески условности при описании, заключающиеся в неожиданной ссылке на используемый код, а не на передаваемое сообщение (типа пушкинского -Читатель ждет уж рифмы розы; на, вот возьми ее скорей(॰), можно уподобить условности обращения к публике в сере- 
дине действия (например, Ганс Вурст в средневековой комедии): и там и здесь имеет место выход на уровень метаязыка по отношению к непосредственному тексту повествования - иначе говоря, выход на периферию описания (на его фон или к.его рамкам), позволяющий оттенить само описание.

Итак, мы можем видеть, что самый прием «произведения в произведении употребителен как при изображении фона, так и при изображении рамок. При этом как для того, так и для другого случая характерно использование внешней точки зрения.

\section{Заключительнье замечания}

Мы стремились подчеркнуть единство формальных приемов композиции в литературе и изобразительном искусстве путем демонстрации некоторых общих структурных принципов внутренней организации художественного ктекстя (в широком смысле этого слова). Это оказалось возможным сделать прежде всего потому, что как произведение литературы, так и произведение изобразительного искусства в большей или менвшей степени характеризуется относительной замкнутостью, т.е. изображает особый микромир, орГанизованный по своим специфическим закономерностям (и, в частности, характеризующийся особой пространственно-временно́й структурой). Далее, в обоих случаях может иметь место множественность авторских позиций, вступающих друг с другом в разного рода отношения.

Авторская позиция может быть более или менее четко фиксирована в литературном произведении - и тогда возникает аналогия с прямой перспективной системой в живописи. В этом случае правомерно ставить вопрос: $\Gamma$ д е был повествователь во время описываемых событий, о т к у д а ему қзвестно о поведении персонажей (иначе говоря, вопрос о в е р читателя автору, о достоверности описания) ${ }^{81}$ - совершенно так же, как по перспективному изображению можно догадываться о месте живописца по отношению к изображаемому событию. Отметим, как более мелкий факт, что с изображением в прямой перспективе сопоставим рассмотренный выше принцип психологического описания с употреблением специальных "слов остравения (типа «вдимо*, «как буд-

81 См.: Гуковский, 1959, с. 201 и сл., а также: Сколес и Келлог, 1966, гл. 7. 
то и т.п.). В обоих случаях характерна субъективность описания, ссылка на ту или иную субъективную - и тем самым неизбежно случайную - позицию автора. В обоих случаях, далее, показательна ограниченность авторского знания: автор может чего-то не знать - будь то внутреннее состояние персонажа в литературном описании или то, что выходит за пределы его кругозора при перспективном изображении; при этом речь идет именно о сознательных ограничениях, налагаемых для вящего правдоподобия автором на собственное знание ${ }^{82}$. Собственно говоря, именно в силу этих ограничений и становится логически правомерным вопрос об и с т о ч н и к а х авторского знания, о котором мы только что говорили.

В этом отношении весьма характерны случаи специального подчеркивания автором ограниченности собственного знания. Помимо уже отмеченных выше случаев, ср. еще характерную .фразу из гоголевской *IIинели", когда автор (рассказчик), сообщив нам, что подумал Акакий Акакиевич, спешит сразу оговориться: ‘А может быть, даже и этого не подумал - ведь нельзя же залезть в душу человеку и узнать все, что он ни думает* (Гоголь, т. III, c. 159).

Не менее знаменательна и нередко встречающаяся попытка как-то объяснить, оправдать авторское знание, в частности, мотивировать проникновение в психику своего героя, особенно характерная для Достоевского. В этом отношении достаточно показательно, например, его предисловие $\boldsymbol{k}$ «роткой : по словам Л.Штильмана, * в своем рассуждении он [Достоевский. - Б.У.] пользуется фикцией стенографа, ведущего запись монолога, правда, не внутреннего, а произносимого (еще одна фикция!) „закоренелым ипохондриком, из тех, что говорят сами с собою“. Для Достоевского, - продолжает Штильман, - вообще характерца̃ забота о мотивировке, о формальном оправдании речи, раскрывающей внутренний монолог. Отсюда пространные диалоги, устные монологи, псевдо-документы: мемуары, дневники, исповеди, письма» 83 .

В то же время по отношению $\kappa$ другой возможной системе описания (изображения) вопрос об источниках авторского знания вообще невозможен, т.е. не является корректным в пределах самой

82 Ср. выше, с. 151. Ср. также примеры из произведений Достоевского, приведенные у Д.С.Лихачева (Лихачев, 1967, с. 326).

83 См.: Штильман, 1963 , с. 330. 
этой системы. Примером может служить эпос в случае литературы и изображение, построенное по принципам обратной перспективы, в случае живописи. Эпическое произведение может оканчиваться, например, гибелью всех действующих лиц, но вопрос ^откуда известно о произошедших событиях - столь естественный для *реалистической литературы - здесь не может быть задан без необратимого выхода за рамки данной художественной системы ${ }^{84}$. Точно так же и изображение предмета в системе обратной перспективы дается не через индивидуальное осознание, а в его данности. Художник в этом случае не позволяет себе изобразить прямоугольный предмет сужающимся к горизонту (как это предписывается правилами линейной перспективы) только потому, что таким он видит его в данный момент и с данной зрительной позиции. Художник изображает свой объект таким, как он е с т ь, а не таким, как он ему к а ж е т с я. Вопрос об относительности всякого вообще знания и, следовательно, о степени доверия к автору здесь не стоит вовсе ${ }^{85}$. Тот же принцип имеет место и в эпосе (ср. постоянные эпитеты в эпосе как формальный признак описания не «кажущегося *, а «действительного бытия) ${ }^{86}$.

Совпадения между принципами построения изображения в системе обратной перспективы и прийншами построенйя опйсивия в эпосе доходят до деталей. Так, для системы обратной перспективы характерно утеснение поля зрения: листва на дереве передается здесь в виде нескольких листьев, толпа людей может изображаться в виде

84 Ука́жем вообще, что сама возможность - или невозможность - задавать вопросы определенного рода может служить характерным признаком той или иной художественной системы.

85 С этим же связана, между прочим, и характерная для древнерусской литературы манера повествования, которую можно было бы назвать приемом ๘безличного остранения - манера говорить 06 известном, как о чем-то неизвеслном, будет ли это обычай, имя исторического лица, название города и т.д. (так, например, повествователь, сообцая о крещении ребенка, может пояснить: १коже обычаи есть христианом имя детищу нарещи - хотя совершенно ясно, что читателю это не может быть неизвестно); см.: Лихачев, 1958, c. 29 .

Таким образом, точка зрения повествователя здесь принципиально независима от читательской позиции, как бы демонстративно к ней не приспособляясь.

86 Условность такого описания может быть констатирована только с позиции какой-то иной системы описания. В рамках же данной системы подобного рода описание — объективно. 
тесной группы из нескольких человек и т.п.87. Ср. аналогичный прием в фольклоре или древней литературе, когда подвиги войска обобщаготся в поведении одного героя, например, Евпатия Коловрата, Всеволода Буй Тура и т.п. ${ }^{88}$. Можно напомнить также о традидионном приеме описания битвы в әпической литературе, когда бой представляется в виде последовательвой серия отдельных е д и н о б о р с т в (например, в •Илиаде Гомера) ${ }^{89}$.

С друто стороны, утеснение поля зрения может иметь своим следствием утрату связи между отдельными изображениями в картине (когда рука лишь касается предмета, а не держит его, ноги идущих люде беспорядочно сталкиваготся и т.п. ${ }^{90}$ ). Но подобное же отсутствие координированности между отдельными әпизодами возможно и в литературе - и именно в силу особой сосредоточенности описания каждого из этих апизодов (сосредоточенности столь сильной, что каждое описание имеет самодовлетоцио денность, а связь между ними утрачивается). Это особенно очевидно в фольклоре; ср. также отмеченное Гёте отсутствие координированности у Шекспира, которое сам Гёте сопоставляет с двоцным светом в картине (заметим, что множественность источников света характерна прежде всего для системы обратной перспективы) ${ }^{91}$.

Точно так же, например, постоянным апитетам в әпическом произведении соответствуют постоянные атрибуты в иконописном изображении: ‘Как „ласковый князь Владимир Красвое Солныпко“ остается „ласковым“ „ирасным солнышком“ при казнях, так точно святые русских икон не расстаготся со своей священной одеждой ни в какое время дня и ночи, ни при кахих обстоятельствах. Святитель всюду в ризе, князь - в княжеском платье или царском венце, воин - с плащом или в воинских доспехах 92.

87 См.: Жегин, 1970, с. 54.

88 См.: Лихачев, 1970, с. 67; Богатырев, 1963, с. 28-29.

89 Ср. сформулированный Ф.Ф.Зелинским єпринцип хронологической несовместимости у Гомера: гомеровское действие, по Зелинскому, знает только последовательное, но не параллельное развитие, т.е. два события никогда не происходят в одно и то же время, но непременно одно за другим (см.: Зелинский, 1896; Зелинский, 1899-1900; ср.: Альтман, 1928, с. 48).

Ср. аналогичный вывод исследователей сказки: •В сказке отсутствует одновременность перемещений разных персонажей (исклюqая, впрочем, ситуации сопутствия и погони). Если приводится в движение один персонаж, то другой должен быть усыплен, умерщвлен, затоqен, заколдован и т.д.» (Мелетинский, Неклюдов, Новик и Сегал, 1969, с. 125).

${ }_{90}$ См.: Жегин, 1970, с. 54.

91 См.: Гёте, 1905 , с. 338 и сл.

92 См.: Соколов, 1916 , с. 12 . Ср.: Подобедова, 1965, с. 40, и особенно Щепкин, 1897 , с. $119-122$; здесь же и вообще о единстве формальных приемов в эпосе и в иконописи. 
Следует подчеркнуть, что при описании как первого, так и второго типа в принципе возможна множественность авторских позиций (точек зрения). Если говорить о живописи, то множественность точек зрения характерна в первую очередь для системы обратной перспективы; однако, как отмечалось, она может быть констатирована и в живописи нового времени - практически на всех этапах эволюции искусства ${ }^{93}$. Что же касвется литературы, то вопреки известному мнению (которое связывает описание, использующее разные точки зрения, с появлением реалистического социального и психологического романа) использование различных точек зрения при повествовании может быть отмечено и в достаточно древних текстах.

Укажем в этой связи, что приек п а р а л л л и и м а, характерный для эпоса самых разных народов, нередко свидетельствует именно о параллельном использовании нескольких точек зрения. Когда говорится, например:

Добрый молодед к сеничкам приворачивал, Василий к терему прихаживал, -

то перед нами не что иное, как описание одного и того же события в двух разных планах - соответствующих двум различным точкам зрения (так сказать, для кого фдобрый молодец•, а для кого - Василий ).

Спорадическую ссылку на разные точки зрения можно обнаружить в ирландских сагах. Например, в описанин встречи Кухулина и Эмер в саге „Сватовство к Эмер сначала описываются Эмер и ее девушки, как их застал Кухулин (и это служит поводом рассказчику вообще дать характеристику Эмер), а потом описывается Кухулин, как его увидели Эмер и девушки (последнее в большей степени передается в прямой речи одной из девушек, что характерно вообще для эпоса).

Использование нескольких противостоящих друг другу точек зрения можно наблюдать и в древнерусской литературе, например, в • Казанской истории (XVI век), где в описании совмецены противоположные точки зрения русских и осажденных казандев ${ }^{94}$. Ср. в этой связи также замечания М.М.Бахтина о многоплановости и из-

93 См. выше, с. $10-11$.

94 См. анализ әтого произведения с других позиций в работах Д.С.Лихачева: Лихачев, 1967, с. 104-107; Лихачев, 1961, с. 646-648. 
вестной полифоничности мистерии, о зачатках полифонии у Шекспира, Рабле, Сервантеса, Гриммельсгаузена ${ }^{95}$.

Указанные принципы описания не следует понимать ни в оценочном, ни даже в эволюционном смысле (хотя очевидно, что последний принцип характерен, например, для средневекового мировосприятия ${ }^{96}$, тогда как первый типичен для нового времени) ${ }^{97}$. Скорее, это две принципиальные возможности, перед выбором которых стоит автор (повествователь или живописец) и которые в том или ином сочетании могут сосуществовать при построении художественного текста. Представляется, что сама возможность подобного выбора в литературе заложена уже в практике повседневной речи, т.е. бытового рассказа (мы старались показать это выше). В самом деле, рассказчик всегда стоит перед выбором, как ему рассказывать - последовательно ли воспроизводить свое восприятие излагаемого события или же представить его в каком-то реорганизованном виде. Реорганизация может быть для вящего эффекта (принцип детектива: сначала делается так, чтобы слушатель не догадался, в чем дело, а потом ему неожиданно пренодносится разгадка) или, наоборот, для объективного изложения фактов (рассказчик не передает своего первоначального понимания, считая его теперь несущественным, т.е. не задает своей позиции, но рассказывает, как все происходило «на самом деле - по его реконструкции).

95 См.: Бахтин, 1963, с. $2-3,47$.

96 Принципиальная объективность восприятия и изображения мира вытекает здесь из непризнания произвольности связи между знаком и обозначяемым, как әто вообще характерно для средневекового мировоззрения.

97 Укажем в этой связи, что само внимание к ме т о д у (в частности, к языку) описания, ставящее сами описываемые факты в зависимость от методики их обнаружения, - иначе говоря, преимущественное внимание к «ак*, а не к что при описании - характерно именно для мировосприятия нового времени (сошлемся, например, на позитивизм в философии, квантовую механику в физике). 


\section{Краткий обзор содержания по главам}

Введение. „Точка зрения“ как проблема композиции . . . . .9

Проблема точки зрения в разных видах искусства (9). Возможные аспекты проявления различающихся точек зрения в художественной литературе (14). Задачи дальнейшего рассмотрения (16).

Условные обозначения, принятые при цитировании (17).

1 „Точки зрения“ в плаве идеология $\ldots \ldots \ldots \ldots \ldots \ldots \ldots 19$

Примеры использования в произведении нескольких точек зрения, проявляющихся в плане идеологии (19)- Полифония (21). Автор, рассказчик и герой (персонаж) как возможные носители идеологической точки зрения (22). Функция героя - носителя идеологической точки зрения в произведении: главный герой и второстепенный персонаж как возможные ее носители (23). Актуальный и потенциальный носитель идеологической точки зрения; проблема «внешней" и «внутренней» точки зрения в плане идеологии (25). Способы выражения идеологической точки зрения: постоянные эпитеты, речевая характеристика и т.д. (25). Соотношение плана пдеологии и плана фразеологии и их отношение $к$ разным видам искусства (27).

2 „Точки зрения“" в плане фразеология . . . . . . . . 30

Иллюстрация процесса порождения произведения, использующего фразеологически различные точки зрения (30). Одна фразеологическая точка зрения в произведении - она может принадлежать автору или действующему лицу (последнее может выступать, в свою очередь, в качестве главного или второстепенного героя) (32). Несколько фразеологических точек зрения (33). 
Наименование как проблема точки зрения (33). Наименование в обыденной речи, публицистической прозе, эпистолярном жанре - в связи с проблемой точки зрения (33). Наименование как проблема точки зрения в художественной прозе (40). Иллюстрация: анализ наименований Наполеона в ‘Войне и мире» Толстого (43).

Соотношение слова автора и слова героя в тексте ........ 48

Влияние чужого слова на авторское слово (49). Наиболее отчетливые случаи использования чужого слова в тексте (49). Объединение различных точек зрения в сложном предложении (50). Несобственно-прямая речь (50). Объединение различных точек зрения в простом предложении (55). Сочетание точек зрения говорящего и слушающего (55). Максимальная концентрация противостоящих точек зрения в тексте: случаи объединения различных точек зрения в одном и том же слове (59); параллели с другими видами искусства (60).

Влияние авторского слова на чужое слово (61). Относительно менее явные случаи такого влияния; внутренняя речь (61). Более явные случаи: влияние автора на прямую речь действующих лиц (63). Некоторые вопросы авторской передачи прямой речи в ‘Войне и мире в связи с проблемой точек зрения - французская речь в «Войне и мире» (65) и картавость Денисова (72).

4Внутренняя" и «внешняя" позиция автора в плане фразеологии (73). Их чередование в тексте (75). Случаи их синтетического (нерасчленимого) совмещения (75). Случаи перевода с авторского текста на индивидуальный язык персонажа и случаи обратного перевода (76). Возможность параллельного использования (дублирования) данных авторских позиций - в прямой речи, в авторском тексте (77).

3 „Точки зрения“ в плаве пространственно-временво́й характеристики . . . . . . . . . . . . . . . . 80

Вводные замечания (80).

Пространство $\ldots \ldots \ldots \ldots \ldots \ldots \ldots \ldots \ldots$.

Совпадение пространственных позиций повествователя и персонажа: автор при этом может целиком перевоплоцаться в то или 
иное лицо (81), либо следовать за персонажем в качестве незримого спутиика (82).

Отсутстние совпадения пространственной позиции автора с позицией персонажа (83). Последовательный обзор (83). Другие случаи движения позиций наблюдателя; деформащия описываемых предметов, обусловленная этим движением (86). Общая (всеохватывающая) точка зрения: точка зрения єптичьего полета (88). Немая сцена (90).

Время ...........................90

Примеры совпадения авторского времени с субъективным отсчетом событий у персонажа (91).

Множественность временны́ позиций в произведении (91). Совмещенная точка зрения (92): совмещение синхронной и ретроспективной точек зрения (92), совмещение точек зрения описывающего и описываемого лица (94).

Грамматическая форма времени и вида и временна́я позиция автора (95). Чередование форм настоящего и прошедшего времени, соответствующих синхронной и ретроспективной авторским позициям (95). Значение формы несовершенного вида прошедшего времени в аспекте композиции (99).

Степень определенности (конкретности) пространственно-временно́й точки зрения. План пространственно-временно́й характеристики в различных видах искусства ............... 102

Аналогии между литературой и другими видами искусства в данном плане (103). Связь литературы со временем, а изобразительного искусства - с пространством (103). Некоторые условия перевода из литературы в другие виды искусства (105).

4 „Точки зрения" в плане пскхологим . . . . . . . . . . . 108

*Субъективное и єобъективное описание (108). Примеры ссылки на то или иное субъективное сознание при повествовании (108).

Способы описания поведения в связи с планом психологии (110). Первый тип описания поведения: внешняя (по отношению $к$ описываемому лицу) точка зрения (111). Ссылка при этом на факты, не зависящие от описывающего субъекта, или же ссылка на 
мнение какого-то наблюдателя (111). Второй тип описания поведения: внутренняя (по отношению к описываемому. лицу) точка зрения (112). Формальные признаки того и другого типа описания: verba sentiendi, слова остранения (113).

Типология композиционного использования различных точек зрения в плане психологии (116). Отсутствие смены авторской позиции при повествовании: случай I (отсутствие вообще какой-либо ссылки на внутреннее состояние (116)); случай II (использование одной какой-то точки зрения, которой может быть точка зрения рассказчика или персонажа - главного или второстепенного) (116). Множественность точек зрения при повествовании (смена авторских позиций): случай III (последовательная смена и функция выбора той или иной авторской позиции в этом случае) (118); случай IV (одновременное использование нескольких точек зрения при повествовании) (127). Возможности трансформационного представления рассмотренных' выше случаев (129).

Проблема психологической точки зрения как проблема авторского знания (129).

Специфика различения точек зрения в плане психологии (131).

5 Взакмоотношение точек зрения на разных уровнях в произведевик. Сложная точка зревия ................. 133

Несовпадение точек зрения, вычленяемых в прӧиведении на разпых уровнях анализа ....................134

Несовпадение идеологической точки зрения с другими (134). Несовпадение плана идеологии и плана фразеологии (135). Несовпадение плана идеологии и плана психологии (136).

Несовпадение пространственно-временно́й точки зрения с другими (138). Несовпадение пространственно-временно́й и психологической точек зрения (138). Несовпадение пространственно-временно́й и фразеологической точек зрения (141).

Совмещение точек зрения на одном и том же уровне ...... 141

Совмещение позиции рассказчика с какой-либо другой при повествовании в Войне и мире (142). Несколько типов рассказчика в Войне и мире и различные случаи совмещения (142). 
«Замещенная точка зрения как возможный случай совмещения точек зрения рассказчика и персонажа (152).

6 Некоторые специальвые проблемы композцик художествевного текста . . . . . . . . . . . . . . . . . . . . . . 155

Зависнмость точки зрения от предмета опксания. . . . . . . . 155

Случаи зависимости принципа описания не от описывающего, а от описываемого (156). Примеры из плана фразеологии, идеологии и др. (156). Аналогии с изобразительным искусством (159).

"Точка зрения“ в аспекте пратматики . . . . . . . . . . . 160

Несовпадение позиции автора и читателя (160); ирония (161) и гротеск (162). Семантика, синтактика и прагматика композиционного построения (163).

7 Структурвая общность разных видов искусства. Общие принципы организации произведения в живописи и литературе . . . . 167

Внешняя и внутренняя точки зрения ... . . . . . . . 167

Проявление внешней и внутренней точек зрения на разных уровнях анализа (167) - в плане идеологии (169), в плане фразеологии (169), в плане пространственно-временно́й характеристики (170), в плане психологии (170). Совмещение внешней и внутренней точек зрения (на определенносм уровне анализа) (171) - в плане идеологии (171), в плане психологии (171), в плане пространственно-временно́й характеристики (172) и в плане фразеологии (172). Внешняя и внутренняя точки зрения в изобразительном искусстве (173).

Рамки художествениого текста ................ 174

Проблема рамок в различных семиотических сферах (174). Проблема начала и конца (174). Границы художественного пространства в разных видах искусства (175). „Рамки в произведении изобразительного искусства (177). Смена внешней и внутрен- 
ней точек зрения как формальный прием обозначения "рамок литературного произведения (181). Иллғострация - применительно к литературе -- для плана психологии (185), пространственно-временно́й характеристики (185), фразеологии (187), идеплогии (188). Составной характер художественного текста (188). Общий текст повествования может распадаться на совокупность все более и более мелких повествований, каждое из которых организовано по одному и тому же принцкпу (т.е. имеет специальные внутренние рамки); аналогии с организацией живописного произведения в этом отношении (191). Организация художественного текста по принципу * произведения в произведении (192).

Некоторые принципы изображения *фона (193). Общие принципы организации *фона в живописи и в литературе (198).

Единство принципов обозначения фона и рамок (204).

Закмючительные замечания . . . . . . . . . . . . . . 207 